




\section{。}






\title{
FRENCH POLICY AND THE AMERICAN ALLIANCE OF 1778
}

\author{
BY \\ EDWARD S. CORWIN, Ph.D. \\ Professor of Politics, Princeton University; \\ Author of "Nationat, Supremacy," "The \\ Doctione of Judicial Review," Etc. \\ "La doiplomatie... ne peut, elle ne doit \\ aroir qu'un but. la force et la grandeur \\ du pays quelle reprisente."-C'apefigue.
}

PRINCETON UNIVERSITY PRESS

PRINCETON

LONDON : HUMPHREY MILFORD

OXFORD UNIVERSITY PRESS 
Copyright, 1916, by

PRINCETON UNIVERSITY PRESS

Published June, 1916

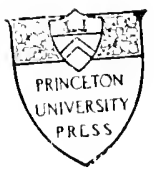

JuL -81910

(c) 014433614 


$$
\begin{gathered}
\text { TO } \\
\text { MY SISTERS } \\
\text { "BEIONED MIALE" }
\end{gathered}
$$

THIS BOOK IS AHFCTIONATELY

IXSCRIBED 


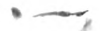




\section{PREFACE}

The materials for the following study were assembled more than ten years ago as a part of work done for the doctorate, at the Universities of Michigan and Pennsylvania. About two years ago I had prepared for publication the portion of the present volume comprising, essentially, chapters I, V, and VIII-XV, when Mr. P. C. Phillips' The West in the Diplomacy of the American Revolution appeared, covering much of the ground of several of these chapters. I then decided to enlarge the scope of the volume to that of a general history of the one entangling alliance to which the United States has been party.

I have been particularly interested in these pages in emphasizing the idea that France's intervention in the American Revolution was motivated primarily by her desire to recover her lost preëminence on the Continent of Europe. Writers have sometimes made verbal recognition of this fact, but in the case of American writers at least, they have generally failed to appreciate its really controlling importance for the subject, and in the end have usually contrived-thanks, 
no doubt, to Professor Seeley's famous dictumto present French intervention as an episode in the British-French struggle for colonial dominion in the Western Hemisphere rather than for what it really was, an episode in the European policy of the Ancien Régime. A second phase of the general subject to which I have given prominence is the embarrassment which resulted to France from the conflict of interest between her new ally, America, and her hereditary ally, Spain, a conflict which greatly enhanced the difficulty of getting Spain into the war in the first place; which subsequently forced France to make a very restrictive interpretation of certain of her engagenents with the United States; and which finally eventuated in the breach of their instructions by the American commissioners at the negotiations of 1782. Lastly, I have felt that it would be a service to American students to make the materials in Doniol's monumental work more available. These materials, supplemented by the other sources that I have used, will be found, I think, to furnish adequate basis for judgment with reference to most, if not all, of the more important questions likely to suggest themselves to an American student of the Alliance of $\mathbf{1 7 7 8}$.

In gathering nıy materials I have incurred obligations to several libraries, which I gladly take this opportunity to acknowledge: to the Penn- 
sylvania Iistorical Society, the American Philosophical Society, and the Ridgeway Branch Libraries of Philadelphia, for the use of numerous eighteenth eentury publications, both French and English; to the University of Pennsylvamia Library, for the use of its extensive collection of materials on the Mereantile System; to the Harvalrd University Library, for the use of the Jared Sparks Manuseripts; to the Ameriean Antiquarian Society Library at Worcester, for the use of newspaper's of the Revolutionary period; to the Library of Congress for numerous services. I should also note a more special obligation to the staff's of the University of Michigan and the University of Pennsylvania Libraries and of the Princeton University Library, for many courtesies.

My other indebtednesses are not extensive, but they are deep. I wish especially to record my grateful recognition of the aid which I received from my teachers, Professors A. C. MeLaughlin and W. E. Lingelbach, in the early stages of my labor's.

May :5, 1916.

$$
\text { E. S. C. }
$$





\section{CON'TEN'TS}

CHAPTER

PAG F:

I-The Question of Motive.......... 1

II - The Classical System and British Sea-Power 23 III-Vergennes Discovers the American Revolt 54

IV-The Portuguese and Corsair Questions... 80

V-Florida Blanca Defines Spain's Position.. 105

VI-Vergennes, Alarmist and Propagandist... 121

VII-The Treaty of Alliance and Outbreak of War ................... 149

VIII-Spanish Mediation and the Convention of Aranjuez ............... 173

IX-The Two Alliances Compared. . . . . . . 195

$\mathrm{X}$-The Mississippi and Western Land Question ..................217

XI-Sieur Gérard and the Continental Congress 243 XII-The Mission of La Luzerne.......... 263

XIII-The Crisis of the Revolution.........284

XIV_Jay's Mission to Spain........... 318

XV-Jay and the Negotiations of 1782 . . . . 329

XVI-Profit and Loss.............. 361

Bibliographical Note ............... 379

Appendices . . . . . . . . . . . . 385

Ind $s \ldots \ldots \ldots \ldots \ldots \ldots \ldots \ldots \ldots \ldots \ldots \ldots$ 


\section{,}




\section{CHAP'TER I}

TIIE QUESTION OF MOTIVE

'The great majority of students today would, I suppose, concede that but for our alliance with France, the War of Independence would have ended without independence, and that but for the aid which France lent us secretly in the months preceding Burgoyne's surrender at Saratoga, we should hardly have become allies of His most Christian Miajesty, at least on anything like terms of equality. 'To emphasize the efficacy and indispensability of French aid in the Revolution is, however, only to throw into higher light its aspects of paradox: the oldest and most despotic monarchy of Europe making common cause with rebels against a sister monarchy; a government on the verge of bankiuptey deliberately provoking a war that, to all appearances certainly, it might have easily avoided. Ignorance of the dangers it invited might conceivably afford a partial explanation of the course taken by the French government in the years between 1776 and 1783 , but in fact the explanation is available in onl. slight measure. 'The risk to a monarch in 
promoting rebellion, albeit in another's dominions, was clearly present to Louis' nind, while the unfitness of the royal exchequer for the burdens of war was pressed upon him by Turgot with all possible insistence.

Bancroft explains France's championship of American independence thus: "Many causes combined to produce the alliance of France and the American republic, but the forces which brought all influences harmoniously together, over-ruling the timorous levity of Maurepas and the dull reluctance of Louis XVI was the movement of intellectual freedom."1

The important element of truth in this theory is unquestionable. The direction and momentum of French popular sentiment established, to somie extent certainly, the possibilities and limitations of French official action, and this sentiment was in turn to no inconsiderable extent the product of the liberalism of the age. Nevertheless, the idea that France ought to intervene, if chance offered, between England and her North American colonies in behalf of the latter, came in the first instance, not from the salon but the Foreign Office. And it is not less clear that the precise policy pursued by the French government toward the United States from 1776 on was shaped, not by philosophers but by professional diplomatists.

${ }^{2}$ II istory of the United States (Author's last revision), V. 256. See also ib., 264 ff. 
Confining then our attention from the outset to the question of what were the official motives of French intervention, we have naturally to consider in the first instance the Count de Vergennes' argument in behalf of his program, which eventually became that of the French government, that however the American situation eventuated, it carried with it the substantial risk for France of having to come finally to the defense of her Caribbean possessions against an English attack: since if England subjugated America she would be tempted to turn the large forces she would have on hand to some profitable employment, whereas if she did not, she would make allies of those whom she had lost as subjects in an endeavor to compensate herself at the expense of France. ${ }^{2}$

It was a theory calculated to appeal strongly to the French mind of that day and generation. The Seven Years War had been begun by the British government in the midst of negotiations without a word of warning. It had been conducted by Chatham in a spirit of ferocious antipathy toward France and her ruling House. ${ }^{3}$ It had been concluded by a peace which had been

"Henri Doniol, Histoire d. le Partirivation de la France a l'Établissement des États-Unis d'Amerique (1'aris, 1886-99), I. 273-5; II. 460, 462-3. Cited hereafter as "Doniol."

${ }^{3}$ Expressions of Vergennes' distrust of Chatham will be found in Doniol I. 61-2, 67-72. At the same time he admits in effect the unlikelihood of George III's calling hin to power, ib., 62. 
roundly denounced by an influential section of the English public for restoring to France English conquests in the Caribbean. Moreover, the violence of English party contests was notorious; and to men to whom it had not yet become evident in what a powerful leash George III held Parliament it was natural to suppose that, rather than incur the penalty of a too long delayed triumph in America, the North ministry would be ready, if worse came to worst, to resort to the most desperate expedients.

And not only did the argument in question strike hands with the popular French estimate of British policy; it also countered admirably the strongest argument against French intervention in America, namely, that it meant war with England. Yet these very considerations should perhaps put us on our guard against too spontaneously crediting Vergennes with complete sincerity in this matter; or if we decide to accord him that, we should at least remember his own warning, that "it is human nature to believe readily that which one desires most ardently.,"t

The evidence presented by Vergennes to support a plea of self-defense in behalf of France's action in America we shall pass upon later. Here we need only weigh some more general considerations militating against that plea: 'To

4 Ib.. 11. 790 . 
hegin with, the risks involved in attempting to aid the Colonies secretly were obvious from the first: ret it is on the increment of danger resulting from his own policy at this point that Vergennes based in part his argument for an open alliance with the Colonies." Again, by his own argument, the danger that conf ronted France arose alike from the prospect of English victory and of English defeat in America; yet it will be found that he was quite ready to retreat from his program of alliance with America whenever English victory seemed seriously to impend. ${ }^{\prime}$ In other words, it would seem that, while the danger menacing France from the prospect of an immediate English triumph in America was one to be awaited in calm - the calm of despair, forsooth - the danger which threatened from the opposite contingency was one that must be met half-way. Yet it was the latter contingency precisely which the policy of secret aid was designed to make sure? But, again, while a British attack upon her Caribbean possessions would, of course, have forced France to come to their defense, it may be seriously doubted whether French official opinion held these possessions after 1763 in sufficient esteem to have warranted a policy that materially increased the likelihood of a serious war of which

\footnotetext{
$316 .+234$.

"Ih., 1. 567-75 and 613-21; also 11. 536-9,531-6, 539, and 551-5.

(I)., I. $24 \pi-8$.
} 
their security would be the main objective. ${ }^{8}$ Indeed Vergennes himself declared more than once that the French West Indies could offer but slight temptation to English cupidity, that England already had enough of that sort of thing; ${ }^{9}$ and it is significant that during the negotiations of 1782 he stood ready to surrender some of the most valuable items of these possessions if he could thereby procure Gibraltar for Spain. ${ }^{10}$ Finally, there is good reason for believing that France could, at any time before 1778, have obtained from England a specific guaranty of her American holdings-a guaranty which Spain would have been glad to sanction, and which England would have been slow to violate, so long at any rate as peace continued on the Cortinent. ${ }^{11}$

"See the remarks of $M$. Abeille, quoted infra. In the same connection one should also recall the pacifist attitude of the French government early in 1777 toward the question of defending Santo Domingo, the obvious explanation of it being the fear of arousing suspicion on the part of Great Britain tlat would prejudice the policy of seeret aid: Doniol, II. 234-41, 253, 264-5, 272-5.

${ }^{9} / 6$. . II. 643-4; III. 50-1. See also Life of Arthur Lee, I. 361.

${ }^{10} I b ., \mathrm{V}, 220$. It should also be noted that throughout the war France definitely subordinated obvious opportunities to enlarge her holdings in the west Indies to other objectives. "Mu vrai," says Iavisse, "les intérêts coloniaux paraissaient à Vergennes, comme à presque tous les hommes d'Etat français, de médiocre importance," Histoire, IX. 117.

"Both at the end of 1776 and in the spring of 1777, the British Government suggested a common disarmament on the part of England, France, and Spain, Doniol, II. 145-54, 232 . An earnest actvocate of such a plan, which was to be accompanied 
The principal reason for Vergennes' constant employment of the line of argument under discussion undoubtedly lies in its propagandist use. Before, of course, any diplomatic program could be entered upon it had to receive the assent of the king. Had the idea of an aggressive program been unbiased by other considerations it would probably have had Louis' assent from the start, for ignorant as he was of domestic affairs, he was well rersed in dynastic polities and jealous for the honor of his House. But unfortunately for such a program, Louis had ascended the throne promising reforms that forbade ambitious sehemes abroad; and besides, an endeavor to

Iy a joint guaranty hy the parties to it-France, Spain, Fingland, and Portugal-of their possessions in America and the two Indies, was Beaumarchais' friend Lord Rochford, a nember of the ministry, Wharton, 111. 727-8. Vergennes however had from the first been averse to seeking any sort of understanding with England, Doniol, I. 51-2; P. C. Phillips, The West in the Diplomacy of the American Revolution (Univ. of Ill., 1913), 38 fn. 25 and 54 in. 74 ; B. F. Stevens, Facsimiles of Manuscripts in European Archices Relating to America, 1\%\%3-1 $\% 83$ (London, 1849-98, 25, vols., cited hereafter as SMSS.), Nos. 1533, 1544, and 1549. In Aug., 17it, we find Vergennes arguing against France's accepting n British guaranty of lirench and Spanish possessions, Doniol, 11. 528-9. At the very end of the year, that is after Saratoga, if we are to credit a statement attributed by the Spanish ambassador Aranda to V'ergennes, the English govermment was offering France the Island of Cape Bréton and Nova Seotia, together with extensive rights in the Newfoundland fisheries, if France in return would close lier ports to the rehels. Aranda to Florida Blanca, Jall. 31, 1778, Sparks MSS. (Harvard Univ. Library), CII. See also SMlss., No. 1838. 
strike at England through America involved the naturally unwelcome idea of assisting rebels." $11^{\text {* }}$ Nor could Vergennes' calculations stop short with his own sovereign. For the logic of the Family Compact clearly exacted that the Spanish court too should be consulted about measures that might involve it in war. How, then, could the Foreign Office better meet the twofold necessity before it than by giving its program as much as possible of the appearance of a program of defense? With Louis the device succeeded, and probably no other would have. At Madrid, on the contrary, though the argument was plumed especially for the favorite anxieties of that court, it failed utterly; with the result however that the argument of defense had to $b \epsilon$ pressed upon Louis with fresh insistence, in order to induce him to take a line different from that of his uncle and ally.

In short, while the argument that England designed to attack her Caribbean possessions assisted materially in bringing France into the Revolution, especially by tending to minimize

11n One of the few literary remains of any importance from the tand of Lonis XVI is a note seribbled on the margin of a Projet of the "Exposé des Motifs de la Conduite de la France," etc., of 1789 , to protest against Vergennes' assertion that France had only recognized a people already free. "Cette observation," runs the royal gloss, "pourrait autoriser . . . Mngleterre à aider ouvertement les mécontents si souvent agités en Bretagne, nos protestants, et tous les Français discordants d'avec l'autorité royale." Capefigue, Louis KII (Paris, 1856), 107-9. See also Appendix IV. 
with the king the weightiest consideration against such a project, it does not follow that the defense of these possessions fumished the principal purpose of French intervention. 'The central core of 'Vergennes' program from the first was aid to the Americans in the achievement of their independence: and the prospect of American independence necessarily brought into riew objectives which far orershadowed the security of the French West Indies, either momentary or permanent. French intervention in the Rerolution was, in other words, determined by motives of "aggression" rather than of "defense"; which is to say that its real purpose was the upsetting of the status quo in certain particulars rather than its preservation in certain others. But in what particulars! Was France's objective territory, or commerce, or was it something less tangible pain either of these?

II

' 'The possibility that it was territory is raised by the contention of Professor 'Tumer that France hoped in the Revolution to replace Fngland in Canada and Spain in Lonisiana. In support of this thesis Professor 'Turner adduces first, the testimony of Godoy, "the Prince of Peace," that after the war was over, Vergennes, comnting upon the close union hetween France and Spain, songht to induce the latter, "already so rich in possessions berond the sea, to give to 
France her ancient colony"; secondly, the fact that during the war Vergennes appeared anxious "to protect the interests of Spain in the country between the Alleghenies and the Mississippi"; and thirdly, a document published in Paris in 1802 under the caption Mémoire historique et politique sur la Louisiane par M. de Vergennes. ${ }^{12}$

Upon closer scrutiny each item of this evidence must for one reason or other be disallowed. 'The reliability of the testimony of Godoy, who did not come into power until six years after Vergennes' death, is in itself questionable, but even if it be accepted at face value it says nothing of Vergennes' intentions before and during the Revolution. Vergennes' attitude during that period toward Spain's claims to the territory between the Alleghenies and the Mississippi is sufficiently accounted for by his feeling that it was necessary to harmonize the conflicting $x_{1}$ terests of the United States and Spain, eac. I whom was in alliance with France against $\mathbf{E}$. land. 'The document published in 1802, thour it may possibly date from the Revolution, was no the work of Vergennes nor yet of any one who spoke for him. Not only does the program that it proposes directly traverse, in its reference to Canada, the pledge of His Most Christian Majesty in article VI of the 'Treaty of Alliance, renouncing "forever the possession ... of any

12 American Ilistorical Reviez, X. $249 \mathrm{ff}$. 
part of the continent" that had lately belonged to Great Britain, but it materially conflicts with the policy which Professor 'Tumer himself' acknowledges that Vergennes pursued, of supporting Spain's claims in the region between the Alleghenies and the Mississippi. 'This policy was clearly designed to allay Spain's alarm at the prospects of American independence. 'The program urged in the Mémoire of 1802 proposed, on the contrary, the deliberate angravation of this alarm as the easiest means of inducing Spain to relinquish Lonisiana to the stronger hands of Franee.

${ }^{13}$ See the Memoire, pp. 25-30. Other considerations that forbid the attribution of this document to Vergennes or official associates of his are the following: It is to be noted that while the anonymous editor of the Mémoire assumes to vouch for "the style, the thoughts" of the document as being those of the French secretary, he says nothing of a signature, nor does any appear in the published form. The Mémoire is also devoid of certain distinctive marks of a French official doeument addressed to royalty. The most obvious consisting in the failure of the writer (or compiler) ever to refer to France and Spain by the titles of their Bourbon rulers. If we are to rely upon the silence of the Inrentaire sommaire, no memoir on Louisiana exists in the lirench archives of the date to which the Mrmoire published in 1802 is assigned by its editor, though several are to be found there of an earlier date from which this one might have been faloricated, and to one of these the editor makes specific reference in a footnote. Furthermore, the fact that the Yemoire of 1802 was, if at this point we are to follow the editor, found among Vergennes own pilpers of itself casts donbt on its ever having been presented to the king. In connection with his statement that "both French and American bibliographers have accepted" the "genuineness" of the 
But if France's objective was not territory, perhaps it was commerce? Unquestionably there was a widespread belief in France early in the Revolution, which was appealed to not only by

Memoire, Professor Turner cites only the l'oyaye a la Lomisiane of Baudry des Lozieres. Yet Baudry, while praising the Mémoire for "plusieurs des ses vues qui sont très sages," directly challenges the assertion that it was the work of Vergennes. "If," says he, "M. de Vergennes has any part in these memoirs, it is only a very snall part." But perhajs the most remarkable teature of the document under consideration is (assuming it to date from before 1783) the ignorance it discloses on the part of its author that by the Treaty of 1763 Florida helonged to Great Britain (see pp. 26 and 30). The Duke of Newcastle is reported to have once addressed a despatch to "the Governor of the Island of Massachusetts." But Vergemnes was neither a British peer nor a spoilsman in office, but a man noted among his contemporaries for the range and accuracy of his intormation in the field of diplomacy. It may be safely assumed, therefore, that he was fully aware that France's closest ally had lost an extensive province by the Peace of Paris and had been compensated by France herself with a still more extensive one. Besides, as is shown below, the Mimoire of 1802, considered as an entity, nust by any assumption date from a period later than early January, 1778. Before this however, Holker, in instructions dated Nov. 25, 1777, was informed by the French Foreign Office that his government wished to see England left in possession of Florida, Nova Scotia and Canada, Doniol, II. 616. Upon careful examination of it $I$ am convinced that the Wimoire of 1802 comprises two earlier documents loosely joined together by the author of the short address "Au Roi," chapter 1 , and certain paragraphs of chapter $\mathrm{X}$ of the published document. 'The first of these two earlier documents comprises most of chapters II-X of the Mémoire of 1802 and was written before the outbreak of the Seven Years War to refute Great Britain's claim to the region then in dispute between France and Great Britain. It closed with a plan of compromise in the form of a proposed treaty between the two nations, which plan is 
the American envors but by Vergennes himself on oecasion, that if France assisted the United States to their independence, American trade

touched up at points by the compiler of the 1802 docmuent. The second of the carlicr documents was written after the rents described in pages 162 to 169 of the pullished volume-i.e. about 1769-to protest against the then recent ression of lousiana to Spain. The entire separateness of the two documents is attested by the words with which the seeond one opens ("Ce mémoire a pour but," ctr., p. 115), by the vastly different style's of the two docoments, and by their diverse spelling of certain proper names. (In the latter comnection compare pp. 57 and 150-1; also ple. 61 and 172.) When, then, was this compilation made? Dismissing the editor's assertion that the docment was the work of Vergennes, but taking the document itself at face value, it was hrought together after the outhreak of the War of Indrpendence (Chapters I and X), hut hefore the Treaty of Alliance recognizing American independence was known the United States are always referred to as "colonies" and "provinces" and on p. 180, the compiler speaks of "strengthening the peace "hetwcen France and (ireat Britain") ; also during a warlike situation on the Continent (Pp. 27 and 10.3, by the (ompiler). But this last condition (an be satisfied, for the period hetween 1775 and 1781 , only by supposing the references just cited to have been to the erents leading up to the so-called War of the Bavarian Succession. It, then, the Mimoire of 1802 is to be assigned as a whole to the period of the Aneriean Revolution, it must be placed between late Jannary and the midule of March, 177s. We know that, in the months preceding leance's intervention, numerous memoirs were transmitted to the Foreign Office, and the Hemoire of 1802 may therefore represent ane from a sheaf of similar later productions. Doniol I. 242 footnote. Mr. Paul C. Phillips, on the other haud, conjectures plausibly that the document published in 1802 owes its existence to an effort to bolster up Napoleon's then recent acquisition of Iomisiana, The I'est in the Diplomucy of tho American Recolution p. 30 fn. 2. 
would turn forthwith to French ports. ${ }^{14}$ Yet squarely confronted with the theory that this belief had been material in determining his program, Vergennes unqualifiedly rejected the notion. "They perhaps think at Madrid," he wrote after the alliance had been determined upon, "that the interest of acquiring a new trade had principally decided us." But he repelled the suggestion thus: "This motive, assessed at its true worth, can be only a very feeble accessory. American trade, viewed in its entirety and subject to the monopoly of the mother-country, was undoubtedly a great object of interest to the latter and an important souree of the groweth of her industry and power. But American trade, thrown open as it is to be henceforth to the avidity of all nations, will be for France a very petty consideration."

These words of Vergennes have, however, no merely negative value; they bring us in fact to the very threshold of the object of our quest. Official thinking about trade was moulded in the

"Wharton, Diplomatic Correspondence of the American Revolution (Washington, 1889), 11. 79; Deane Papers (N. Y. Hist'l Soc. Cols., 1886), I. 181, 184 ff., 207; Doniol, I. 244 . Deane later changed his views on this as well as certain other subjects. In his letter of June 10,1781, to Robert Morris, he says: "America left at liberty will, I am persuaded, take at least three-fourths of the European articles she wants from Great Britain," Deano Papers, IV. 406.

${ }^{15}$ Doniol III. 140. Madrid received its impression from Aranda, Aranda to l'lorida Blanca, Jan. 31, 1778, Sparks MSS., CII. 
eighteenth century in vast part by the categories of what is called "the Mercantile System," and it is the significance of the words just quoted that they show Vergennes to have been of this school. The salient features of Mercantilism mark it at once a system of statecraft rather than of ecomomics, at least in any modern sense of these terms. 'Thus wealth was identified with that form of it in which, in a period when the machinery of public credit was rudimentary and the usual eement of international alliances was provided by cash subsidies, it was most available for political purposes. Again, the welfare of the subject was assessed for its contribution to the power of the state. Finally, the power of the state was evaluated in the terms furnished by the doctrine of the Balance of Power. But granting these premises and it followed, first, that the principal adrantage to be sought from trade was a balance payable in coin or bullion, and secondly, that the most desirable branch of trade was that which was most susceptible of manipulation to produce such a balanee, in other words, colonial trade. For subject as it was, within the laws of nature, to the unlimited control of the mothercountry, the eolony could be compelled to obtain all its manufactures from the mother-country and to return therefor raw materials and a cash halance. At least, by furnishing the mothercountry raw materials which she would otherwise 
have to purchase from her political rivals, the colony would contribute directly to the maintenance of a favorable balance of trade and, pro tanto, to that of a favorable balance of power, against those rirals. ${ }^{16}$

${ }^{30} \mathrm{~A}$ good general account of the rise of Mercantilism and of its principles is to be found in C. F. Bastables Commerce of Nations (1899), ch. IV. For an admirable statement of the connection which mercantilist theory and policy established between colonies and commerce, see lrof. C. M. Andrews, American Historical Review, XX. $43 \mathrm{ff}$. "During the greater part of our colonial period commerce and colonies were correlative terms, unthinkable each without the other," $i b .43$. See also the same writer's article, ib., XX. 589 ff., entitled "Anglo-French Commercial Rivalry, 17001750." "France and England were fairly matched rivals, in that their policies were the same, to acquire colonies in the interest of trade, shipping, and manufactures, to exchde the foreigner from the colonial market, and to make the welfare and wealth of the mother state the first and chief object of the efforts of all, colonies and mother-conntry alike," $i 6 ., 546$. It will be noted that Professor Andrews makes welfare the ohjective of the mercantile policy, but powes would perhaps be the better word even for English mercantilism. Note the following passage quoted by Professor Andrews from Otis little's The State of the Trade of the Northern C'olonies C'onsidered (1748), pl). 8-9: "As every state in Europe seems desirous of inereasing its trade, and the acquisition of wealth enlarges the means of powes, it is necessary, in order to preserve an equality with them, that this kingdom extend its commerce in proportion; hut to acquire a superiority due encomragement ought to be given to such of its branches as will most effectually enrich its inhabitants. As trade enables the subject to support the administration of govermment, the lessening or destroying that of a rival has the same effect as if this kingdom had enlarged the sources of its own wealth. But as an ascendancy is to be grained by cheeking the growth of theirs, as well as ly the increase of our own, whenever one of these happens to be the consequence of the other to this nation, its figure and 
Applying these considerations to the case of French intervention in the Ameriean Revolution, we note at once that by the 'Treaty of Anity and Commerce all privileges of trate were to be "mutual" and none given France but what the United

reputation will rise to a greater height than ever." /b., 543 footnote. In other worke, the mereantilint looked beyond the welfure of the subject to the procer and reputation of the State, and these he measured by the standarel set hy the doctrine of the Balanes of lower. The same point is also brought out by a passage from Postlethwayt's Britains commercial Interest Explained and Improced (175\%): "I next enter upon the general principle" whereon the halance of trade is founded-the consideration of which is earnestly recommended to the pullix regard, in order to throw the balance of trade so effectually into the hands of Great Britain as to put the constant halanep of power in Europe into her hands," ib., II. 551. See also Gentleman's Magazine, XII. 5so (Nor.. 1742): "Now, that Money is the Sinews of $\mathrm{War}$, is hecome a proverhial Expression; and, with Respect to Great Britain. it is notorious we can do nothing without it. Almost all we did in the last Struggle with the Grand Monaleh, was by the Dint of Money. If we had Numbers of Allies, we were obliged to pay them all; and whereas every other Power in the Confederacy run into Arrears with their Engagements, we not only male good our P'roportions, but often exceeded them. . . But, to suppose what is inpossible, that we still roll in Riches, who is to join with us in this mighty Enterprise, of wrentling the Balance of Europe out of the strong Fland that hath lately hed it:" See further the index of this same preriodical under titles, "Balance of Power" and "France," for other instructue passages along the same lines, especially in the volumes covering the years from 1737 to 17.2. Naturally in France, where the dynastic primeiple was the exclusive hasis of the state, the political aspect of Mercantilism was predominant. Recall Colbert's assertion: "I helieve that mont people would be agreed that the quantity of gold in a state alone determines the degree of its greatuess and power," Lettres, etr. (l'. Clement. eol.) 1I. pt. 2, revii. See alos infar. 
States were left at liberty to grant to any other nation, while by the 'Treaty of Alliance, its "essential and direct end" was stated to be the achievement of American independence not only in matters of govermment but of commerce also. ${ }^{\text {i }}$ In other words, we discover that the real commereial motive underlying the alliance was not the hope of building up French trade-which it was supposed could hardly be done effectively or advantageously without the machinery of monopoly-but that of breaking down British trade at the point at which, by mercantilist premises, it most immediately supported British power. 'The commercial motive merges itself with a larger political motive: the enfecblement of England. ${ }^{18}$

'The lesson that Englishmen themselves drew from their magnificent triumph in the Seven Years War is to be found in the famous lament of Chatham on the news of Saratoga: America "was

${ }^{17}$ Treaty of Amity and Commerce, preamble; Treaty of Alliance, art. II.

${ }^{13}$ Congress' original intention was to throw open its commerce to all friendly nations on terms of equality, and the argument was made with France that if she gave America aid the gratitude of the American people would secure her a preemption of American trade. Wharton, II. 79 and 235 . Later, December 30, 1776, the instruclions of Congress enlarged the discretion of the commissioners as to the terms they might offer France and Spain very greatly, $i b ., 240-1$. Eventually, the commissioners offered France certain exclusive privileges in connection with American trade, but theme Vergennes declined, in order to remove every temptation from the way of the Americans that might lead them to a reconciliation with England, Doniol, II. 837. 
indeed the fountain of our wealth, the nerve of our strength, the mursery and basis of our naval power." 1: But what should be especially noted of these words is that they refer to the part of America then in revolt, that is, to continental America. Anterior to 1760 this could hardly have been the case. For then the emphasis was still on colonies as sources of supply, with the result that when British opinion appraised the two parts of British America, it gave the preference to the island and tropical portion. 'The 'Treaty of Paris, however, signalizes a new point of view. Not only had continental America made direct contributions to the military forces of the mothercomtry in the comrse of the war just closed, but its increasing inportation of British manufactures in exchange for raw materials now netted a favorable balance that quite eclipsed the calculable benefits from the West Indian trade. Furthermore, inasmuch as the colonial trade had always been regarded as the essential matrix of British naval strength, popular esteem naturally turned increasingly to that branch of this trade which promised a progressive extension. The upshot of these developments is to be seen in the decision of the British government, registered in

'Speech of Nov. 1s, 17\%7, Parliamentary IIstory, XIX. col. 365, fontnote. Sec to the same effect Burke's speech of Nov. 27, $1781, i b .$, cols. $721-2$. See also the opening paragraph of Deane's memoir on the "Commerce of Auncriea and its Imporlance to Europe," ciled above, Deane l'opers. I. 184. 
the Treaty of Paris, to retain Canada instead of Guadaloupe and Martinique from its French conquests. No doubt the decision was in part motivated by a desire to meet the demands of New England; but the discussion that attended it proves that it is also to be regarded as a deliberate reappraisement by England of the relative value of the two sections of her western empire. ${ }^{20}$

'The reaction of France, on the other hand, to the lesson of the 'Treaty of Paris was conditioned in the first instance by the plain impossibility of further competition with Great Britain in the field of colonization, at least so long as British naval strength remained predominant. However, the doctrine of the Balance of Power which, as I have already pointed out, was the political obverse of Mercantilism, emphasized the notion that the grand desideratum for a state was not so much a certain absolute quantum of power as a certain rank of power in relation to other rival states, that, in short, power was relative. But this premise assumed, the opportunity presented France by the American revolt was a deduction at once inevitable and irresistible. England was France's ancient and hereditary enemy. The essential basis of English power was English commerce and English naval strength. 'The most important source of these, in turn, was England's colo-

3o For the matter of this paragraph, see George Louis Beer, British Colonial Policy. 1\%5,-1765 (N. Y. 1907), ch. IV. 
nial empire, and especially her holdings in North America. 'The striking down once and for all time of the connection between England and her rebellious provinces would deprive her of the greatest single source of power and, by the same token, elevate the power of the House of Bourbon against its most dangerous and unscrupulous rival. 'To achieve that would be worth a war otherwise "somewhat disadrantageous."

Nor was the enfeeblement of England the only benefit, though the most important one, to be anticipated from Ameriean independence. For one thing. from being an ever available base of operations against the French West Indies, the new nation would be converted into their joint protector "forever." Ag2 Again, from being a beneficiary and so a prop to those rules of naval warfare by which Great Britain bore so hard upon the commerciat interests in wartime both of her enemies and of neutrals, the new nation would be pledged to a more liberal system. ${ }^{23}$ Again, by leaving England her non-rebellious provinces in

"See especially the following passages: the "Leftexions" of Dec. 1775, Doniol, I. 243-4; the "Considérations" of Nov. 5, 1776, ib., $6 \times 6-\tau$; the nofficial "Reflexions" of Jan. $\tau, 1 \tau \tau \tau$, given in Appendix II; the despatch of Mar. I1, 1787, il., II. 939; the despatch of May 23, I77\%, ib., 295; "Hémoire" of July 93, 1777, ib., 461; the despatch of Dee. 13, 1767, ib., 643-1; Broglie"s "Mémoire" of Jill., $1778, i b ., 674 \mathrm{ff}$; the despatch of .Innc $20,1778, i b ., 111.140$.

"Treaty of Alliance, art. Xl.

$\approx$ Treaty of Auity and Commerce, arts. XV. ffg. 
North America, a certain portion of England's strength and attention would be permanently diverted from the European balance to the maintenance of a minor balance in the Western Hemisphere. $^{24}$ Yet it is obvious that these considerations too connect themselves, and for the most part rather directly, with the logic of the doctrine of the Balance of Power. 'Thus the real question raised by our search for the main objective of French intervention in the Revolution becomes the question of the main objective in the thinking of French statesmen of a balance of power facorable to France. 'The answer to that question reveals the third dimension of French diplomacy of the Old Régime-a certain dynastic tradition.

${ }^{2}$ Doniol, III. 156-58, 557; IV. 74. 


\section{CIAP'TER II}

THE CIASSICAL, SYSTEM AND BRITISH SEA POWER

"'The diplomatic object of this erown has been and will always be to en joy in Europe that rôle of leadership which accords with its antiquity, its worth, and its greatness; to abase every power which shall attempt to become superior to it, whether by endeavoring to usurp its possessions, or by arrogating to itself an unwarranted preeminence, or finally by seeking to diminish its influence and eredit in the affairs of the world at iarge." "

In these words of the French Foreign Office, penned in 1756 to justify the Diplomatic Revolution, is sketched the pieture that dominated French diplomacy throughout the declining years of the Old Régime. In "the fair days of Lonis XIV" the picture had been a reality,

'Recueil des Instructions donnes au. Ambassadeurs et Minintres de la France depuis les Traités de Westphalie jusqu'a la Revolution Françise (Ed. Sorel, Paris, 1884), I. (Antriche), 356; see also p. 383. See also the siguificant definitions of the function of Diplonacy, in Capefigue, Louis XVI, ses Relations diplomatiques, 81; and in P. I... Conte de Ségur, aine, Politique de tous les Cabiuets (2nd ed., 1801, 3 rols.), III. 370. Both Capefigue and Sigur were of the Old Regime and wrote from its point of view. 
which, alack, that monarch's later aggressions had gone far to shatter. 'Then Cardinal Fleury had come forward with his Système de Conservation by which France pledged Europe that in return for influcnce she would forego extension of dominion and that she would devote the influence rouchsafed her on these terms to the cause of Europe's peace. ${ }^{2}$

'The success of the System for France's diplomatic position was astonishing. On the eve of the War of the Austrian Succession the elder branch of the House of Bourbon, the protector of Christion interests in the Fast, of Poland, Sweden, Turkey, Saxony, Sardinia, the German princes, of Don Carlos of Naples, of the emperor himself, and the ally of the maritine powers and of Spain, was the nodal point of every combination of powers in Europe. At the same time $\mathbf{H i s}$ Most Christian Majesty's services as mediator were sought, now by Austria and Spain, now by Rus-

"M. de Flassin, Histoire gentrale et raisonnie de la Diplomatie. française depuis la Fondation de la Monarchie jusqu'd la Fin du Règne le Louis XYI (zud. ed., Paris 1811, 7 vols.), V. $167 \mathrm{ff}$. On the general principles and outlook of French diplomacy following the death of Lous XIV and the oricntation of Vergennes' policy in these, see Albert Sorel, LEErope et la Rivolution francaise, Pt. 1. (Les Meours politiques et les Traditions) (3rd ed, Paris, 1893), 331-6, 999-304. For some excellent eighteentl century expressions of the "Tradition of Grandeur," dating from Louis XIV, see Abhé Raynal's Philosophical and Political Mistory of the Settlements, etc. (Traus, by Justament, London, 1777), IV. $560 \mathrm{ff}$, V. 457 ff.; also Anquetil's Motifs des Guerres et des Traités de Paix de la France (Paris, 1797), $187 \mathrm{ff}$. 
sia and Turkey, now by Austria and Russia, now Dy Spain and Portugal, now by Fngland and Spain." "Thanks to Cardinal Fleury," exclaimed the adrocate Barbier, "the king is the master and arbiter of Europe." 'The aged Fleury himself complacently compared the position of France to what it had been "at the most brilliant epoch of Louis XIV's reign." Frederick II. just ascending the throne of Prussia, found "the courts of" Viemua, Madrid, and Stockholn in a sort of tutelage" to Versailles." 'The Sultan's ambassador at the coronation of Charles VII apostrophized Lomis XV as "Grand Monarque," "King of Christian Kings," "Fmperor" of the Franks." 'The enemies of Walpole, who in return for commercial favors to England had willingly comnived in the extension of French influence, declared that Fngland had been made a eat's-paw of, that the House of Bourbon was at

"For these data, see Iavisse et Ramband, II istorie Generale, VIl. 119-60.

' $11, ., 154$.

"Rerueil dess Instructions, 1, 216. A pamplutet of the period contains a squib entitled "Jen de l'iquet entre les Puissances de l'kurope en 1730." "Ia lrance" heads the lint, with the motto: "("ent a moi a joner, j'ai la main." lar down the list is "l Angleterre," who sily: "Ce lient pas ì mon tour de jouter." Capefigue, Diplomatir de la France of de l'Espague" (I'aris, 1846), 108.

- Posthumons works of Frederirk II ('Trans. Wy IIolcroft, London, 1789), 1. 16.

igentleman's Magasine, XII. it (1712). 
the summit of power, that the balance of power was at an end. ${ }^{8}$

Nor did the war of the Austrian Succession, rising like a drama to its climax in the stage-triumph of Fontenoy," though obviously a defeat for salient principles of Fleury's System, ${ }^{10}$ signify any lessening of France's influence on the Continent in the estimate of those who then guided her destinies. Foremost of these was the Marquis d'Argenson, who became in 1744 the king's secretary of state for Foreign Affairs on a platform, so to speak, interpreting the rôle of France among the nations in the light of the rising philosophy of the age. The period of conquests, Argenson declared-though unhappily not of war-was at an end, and France especially had reason to be content with her greatness. Those therefore who spoke of perfecting the boundaries of France or forming leagues for her

"See the "Debate in the Lords on Carteret's Motion for the Removal of Sir Robert Walpole," especially Carteret's own speeches, Parliamentary History, XI. col. $1047 \mathrm{ff}$.

'See Voltaire's description in his "Précis du Siècle de louis XV," Oeucres Completes (Paris, 1792), XXI. 129-48. Note especially his words on p. 148: "Ce qui est aussi remarquable que cette victoire. cest que le premier soin du roi de France fût de faire écrire le jour même à l'abbé de la Ville..., qui'l ne demandait pour prix de ses conquîtes que la pacification de l'Europe."

${ }^{10}$ For the policy of a friendly understanding with the maritime powers and Austria. In his instructions of Dec. 11, 1737, to the Marquis de Mirepoix, Fleury suggests definitely a rapprochement hetween the Houses of Bourbon and Hapsburg, Recueil des Instructions, I. 245-6. 
defense were ill-advised. "Our neighbors have ererything to fear from us-we nothing from them." 'The only alliances which France should form should be "for the purpose of repressing the ambitious," and should be made only with lesser states, "such as Portugal, Sweden, Denmark, Holland, Venice, Modena, Switzerland, Bavaria, Prussia, Saxony, etc." In brief, France was in the position to give the law to Europe, so it be a just law. Let her, then, "sustain the feeble and oppressed" and in her part as "paternal protector," "arrest disorders for many eenturies." II In $1 \tau 48$ France, by the 'Treaty of Aix-la-Chapelle, restored her conquests of the war just closed. Sinful Paris pronouneed it "a beastly peace." 'The roval ministers, on the other hand, contrasting His Most Christian Majesty with those rulers who were foreed by necessity to seek only their own aggrandizement and were ever masking selfish designs with a pretended solieitude for the balance of power, defended the treaty as marking precisely France's station and magnanimity. ${ }^{12}$

"Journal et Mimoires du Marquis d'Argenson (ed. Ratheray, l’airs, 1859), 1. 325-6; 371-2; IV. 131 ff. See also Saint-Beuve, "Irgenson," ("useries du Lundi. The idealistic, not to say sentimental, charactor of Argenson's point of view is illustratel by his "naxim," "le roi aime mieux être trompé que de tromper."

${ }^{13}$ For the Parisian estimate of the Peace, see Iavisse et Rambaud, op. rit., VIl. 201. Argenson testifies to the popular critieism eroked by the Peace, thus: "I fe Francais aime la gloire et lhonneur, de sorte quapries les premiers moments de joie de la paix conclue, tout le public est tombé clans la consternation de la 
And thus much for the successful aspect of Fleury's System: it gave France for the time being the preponderance in Europe and it accustomed her statesmen to claim for her in relation to the minor states of the Continent in general the rôle which the 'Treaty of Westphalia had conferred upon her in terms, in relation to the lesser members of the Germanic Body. ${ }^{13}$ Unfortunately the System had its Achilles' heel, its indifference to the decline of French sea-power and to the rise of English sea-power. 'The earliest protest against an attitude so obviously defiant of the tenets of Mercantilism came from Fleury's own associate, the young Count de Maurapas, who between 1730 and $\mathbf{1 7 4 0}$ headed the Department of the Marine. Now in an official report on the state of the marine, now in a letter purporting to emanate from the shade of Louis XIV, now in a memoir on the condition of French commerce abroad, Maurepas reiterated again and again the favorite premises of his school and their obvious deductions for France: Commerce that kept gold at home and drew it from abroad was a source of public greatness. Foreign trade was the essential root of naval strength. Against

médiocrité des conditions." For the ministerial viewpoint, see Recueil des Instuctions, I. $286 \mathrm{ff} ., 319 \mathrm{ff}$. On the preiminence of Iouis' position in Europe after Aix-la-Chapelle, see Wraxall, Historical Memoirs (Phila., 1845), 5.5.

1s On France's guaranteeship of the 'Treaty of Westphalia, see Recueil des Instructions, I. 208. 
no two states in the world could France so profitably turn her arms as against Holland and England. 'The latter moreover was an active menace to Bourbon interests in all parts of the world. It behooved His Most Christian Majesty "to put to flight this usurping race" and to curtail the eommerce which already rendered "these ancient enemies of his crown almost the masters of the fate of Europe." ${ }^{\prime 4}$ It is not impertinent to recall that at the outbreak of the American Revolution the author of these words was His Most Christian Majesty's chief-minister.

The warning thus sounded was soon reëchoed by others. In a council of ministers shortly before France's entrance into the War of the Austrian Succession, the Duke de Noailles opposed this step with vigor and insight. England's system, said he, is obvious. "It is to arrive at supreme power by superiority of wealth, and America alone can make smooth the road for her." It could be predieted at the outset that $\mathrm{His}$ Britamnic Majesty would not waste his substance in Germany, but would seize the opportunity afforded by a war on the Continent to wage war for his own purposes in America. France's real concern should be for her colonies, and only motives of vainglory could distract her attention to the Empire. 'Two year's later Deslandes' Essai

${ }^{4}$ Maurepas, lémoires (ed. Soulavie, Paris, 1792), IlI. 93 ff., 161 fi., 194 fi., especially $20.5-6$ and 241.

- Anquetil, botifs des Gueries, p. 376. 
sur la Marine et le Commerce appeared, addressed to "those at the Helm." In these pages one will find proclaimed the theory to be made familiar to us a hundred and fifty years later through Admiral Mahan's famous work, that from the beginning of history the marine has been a decisive factor in the rise and fall of states. And particularly, Deslandes went on to argue, had the greatness of France always rested on a strong navy. 'The restoration of the marine was therefore the first duty of French statesmen. Its neglect could lead only to calamity. ${ }^{16}$

The mercantilist propaganda, aptly confirmed as it was by the events of the War of the Austrian Succession, began in time to show promise of fruition. Even Argenson, despite his general complacency, yet gave warning that English ambition, fraud, and aggressiveness in the way of trade, and the prosperity of the English colonies, menaced Europe with the prospect of British dominion "of the seas and of all the commerce in the world." 17 Saint-Contest, who became secretary of state for Foreign Affairs in 1751, was of like opinion, holding that, on account of her naval strength, England even then exerted a greater influence in European concerns than France. At

${ }^{16} \mathrm{Op}$. cit., passim. See also the same writer, Essai sur la Marine des Anciens et particulierement sur leurs Vaisseaux de Cuerre (Paris, 1748). Curiously enough Admiral Mahan does not seem to be aware of Deslandes' works.

1i Journal et Wimoires, 1. 372. 
the same time, he contended that naval strength was a highly vulnerable sort of strength, and that with prudent measures, it would be easy for Franee to reduce Great Britain to her proper rank. ${ }^{1 s}$ Meantine, in 1749, Rouillé had become minister of the Marine. Under his administration and that of his suecessor Machault the navy was brought to comparative effieiency, as was attested by the capture of Minorea in June, 17.56.

Unfortunately the Seren Years WVar, thus atuspiciously begum for France, was not long to remain predominantly a war with England, to he waged on the sea for commerce and colonies. 'The simple fact is that with the haute noblesse the army was popular and the navy, for all the zeal of the mercantilists, was not. The prejudices of the nobles moreover fell in with the pique of the king at what he eonsidered the ingratitude and faithlessness of his protégé, the king of Prussia, in making a defensive alliance with England. In vain was it urged upon Louis that the 'Treaty of Westminster, far from implying hostility on Frederiek's part toward His Most Christian Majesty, was really a matter for thanksgiving, in that it guaranteed peace on the Continent and, by the same sign, a free hand for France in India and America. By the first 'Treaty of Versailles, of May 1st, 17.56, the famous Diplomatic Revolu-

"Flassan, op. rit., VI. 14-16; Recueil des Instructions XII." (E-pagne, pt. II), $298 \mathrm{ff}$. 
tion was effected by a defensive alliance between France and Austria. Even so, the general opinion at first was that this arrangement also was calculated to conserve the peace of Europe. On August 29th, 1756, however, Frederick invaded Saxony and the war thus precipitated speedily became general. By the second 'Treaty of Versailles, May 1st, 175\%, the resources of France were placed at the disposal of the House of Austria. ${ }^{19}$

'The fortumes of the ensuing war it is, of course, ummecessary for us to follow further than to note that for France they were misfortunes. 'These were the days when Mme. du Deffand rechristened France "Madam Job." Cardinal Bernis, minister of Foreign Affairs and so official sponsor for the Austrian alliance, was soon in the depths. "Everything is going to pieces," he wrote. "No sooner does one succeed in propping the building at one corner than it crumbles at another." France "touches the very last period of decay:" She "has neither generals nor ministers." "ih that God would send us a directing will or some one who had one! I would be his valet if he wished it, and gladly!"'o

\footnotetext{
1. Lavisse et Rambaud, op. cit., V'11. 217-20; Richard Waddington, Lonis $\mathrm{XV}^{\mathrm{r}}$ et le Rentersement des Alliances (Paris, 1896), 249-62, 3.58-517.

${ }^{20}$ Iavisse et Ramband, op. rii., VIl. 244-5; Richard Waddington. La Guerre de siept Ans, 11. 432-3; Sainte-Beuve, "Bernis," Causeries du Lundi.
} 
In Choiseul, who suceeded Bernis in Norember, 1758, the directing will was found and the mercantilist point of view again assured utterance in the royal council. It is true that Choiseul's first official act was to renew with the empress the onerous engagrements of his predecessor, but to this he was fairly eommitted by the circumstances in which he had taken office."1 Presently we find him declaring to the Austrian court with entire candor that the war with England involved French power and honor more directly than did the struggle on the Continent. Indeed, he proceeded, the interest of Austria herself' demanded the preservation of France's seapower. For "this it is," said he, "which enables His Majesty to sustain numerous armies for the defence of his allies, as it is the maritime power of England which today arms so many enemies against them and against France.", ${ }^{22}$ And the same point of view again found expression in his despateh of Mareh 21st, 17.59, to Havrincourt, the king's ambassador at Stockholm:

We must not deceive ourselves. The true balance of power really resides in commerce and in America. The war in Germany, even though it should be waged with better success than at present, will not prevent the evils that are to be feared from the great superiority of the English on the sea. The king will take up arms in vain.

${ }^{21}$ Waddiugton, op. rit., II. ch. VIII. and III. 452-4.

22 "Instructions 10 the Count do Choisenl," June 1759, Recueil des Instructions, 1. 3 st. 
For if he does not have a care, he will see his allies forced to become, not the paid auxilliaries of England, but her tributaries, and France will need many a Richelieu and Colbert to recover, in the face of her enemies, the equality which she is in peril of losing.":

In October came the news of the fall of Quebec. "The balance of power," wrote Choiseul to Ossun, the king's ambassador at Madrid, "is destroyed in America, and we shall presently possess there only Santo Domingo. France, in the actual posture of affairs, cannot be regarded as a commercial power, which is to say that she cannot be regarded as a power of the first order."24

Choiseul now set himself the task, failing a peace with England on reasonable terms, of restoring to the war its original character of a contest with that power for commerce, colonies, and naval supremacy. Auspiciously for his purpose, Don Carlos, a much better Bourbon than Ferdinand VI had ever been, was now Charles III of Spain. In the negotiations during the summer of 1761 between France and England Choiseul seized the opportunity of championing certain claims of Spain against $\mathbf{H i s}$ Britannic Majesty, which however were rejected by Pitt in terms that aroused not only Charles' indignation but positive apprehensions for his own colonial empire. ${ }^{25}$

${ }^{3}$ Flassan, op. cit., VI. 160.

" Ib., 279.

${ }^{25}$ Waddington, op. cit., III. 437-4?, and IV, 128-37, 555-72. See 
The result was that on August 15th, 1761, the second Family Compact, making France and Spain practically one power for all warlike purposes, was signed at Paris.

The intention [ rums the preamble of this document] of His Most ('hristian Majesty and of His Catholic Majesty, in contracting the engagenents which they assume by this treaty, is to perpetuate in their descendants the sentiments of Louis XIV of glorious memory, their common august ancestor, and to establish forever a solemn monumeit of reciprocil interest which should be the basis of the desires of their courts and of the prosperity of their royal families.

The treaty itself announced its basic principle to be that, "whoever attacked one crown, attacked the other." Thus, when at war against the same enemy, both crowns were to act in concert. When either was at war, offensively or defensively, it was to call upon the other for certain forcesSpain upon France for 18,000 infantry, 6,000 cavalry, 20 ships of the line, and 6 frigates; France upon Spain, for the same naval forces, 10,000 infantry, and 2,000 cavalry. 'The Bourbon holdings in Italy were guaranteed absolutely. also Recueil des Instructions, XII. ${ }^{2} 338$. Of further interest is Alfred Bourget's "l.e Duc de Choiseul et l'Angleterre: la Mission de XI. de Bussy," Revue historique, IXXXI. 1-32. In a letter dated Aug. 25, 1761, Bussy, who was then acting as Choiseul's special envoy to England, wrote: "M. Pitt paraît n'avoir d'autre ambition que celle delever sa nation au plus haut point de la gloire et dabaisser la France au plus bas degré de l'humiliation," ib. 12. 
On the other hand, Spain was excused from assisting France in the guaranty of the Peace of Westphalia unless a maritime power should take arms against the latter. Each power extended to the subjects of the other the commercial privileges of its own subjects in its Europcan dominions." $" *$

'The renewal of the Family Compact was Choiseul's greatest achievenint and is to be regarded as the starting point of the restoration of France's position in Europe; notwithstanding which, at the outset, it brought only tiesh calamities and new losses. In October Pitt íll from power for urging a declaration of war upon Spain. None the less, the declaration followed in January. 'The English and provincial forces now turned from the capture of France's West Indian islands to that of Harana, which fell in July. But Choiseul, his eyes fixed on remoter developments, was determined that Spain should not suffer for her derotion to the Bourbon cause. On November $3 \mathrm{l}^{\circ} \mathrm{d}, 1762$, France agreed to give Spain New Orleans and all of Louisiana west of the Mississippi, an arrangement which permitted the latter to exchange the Floridas for I Arana. 'The ensuing February 10th the Peace of Paris was signed. By it France ceded England

" G. F. de Martens, Recupil de Traités. . . des Puissances et États de l'Erope depuis $1 \% 61$ jusq" à présent (Gottingen, 1871), I. 16-? ? 
the vast part territorially of what was still left of her colonies. Of the great empire that had once comprised half of North Americal and the richest of the American islands, and that had given fair promise to inchude eventually India and the WVest African coast, she retained croree on the Af'rican eoast; Santo Domingo, which thanks to the English diversion against II avalna, her forces still held; Guiana, Martinique, Guadeloupe, Santa Lucia, and their dependencies: the small fishing islands St. Pierre and Miquelon, off Newfoundland; and a few factories in India, together with the islands of France and Bonrbon, which she must not fortify, as also she must not the fishing stations. ${ }^{27}$

Nevertheless, we must be on our guard against exaggerating the merely material aspect of the losses wrought France by the Seren Years War. On the map, no doubt, Camada and Louisiana comprised an impressive domain, but regarded from the point of view of eommerce and tradebalances they were essentially worthless, Louisiana being practically uninhabited and Canada hardly returning the cost of administration. On the other hand Guadelonpe and Martinique, in place of which England had finally and somewhat reluctantly consented to take Canada, were commercially of great value. ${ }^{2 s}$ France's real loss, apart from the enomous outlay of the war, was

:Ib., 101-20; Latrinse et Rambalud, op. ril., Vll. 2isti-r.

"On the perints, see I'lassan, op. cit., VI. 180 ff. 
in prestige. Her armies had been defeated, her fleets annihilated, her allies disappointed and disgruntled. 'The 'Treaty of Peace itself signalized her humiliation most graphically by renewing the defunct provisions of the 'Treaty of Utrecht against the fortification of Dunkirk, to which was later added provision for an English commissioner at that port, "without whose consent not a pier could be erected, not a stone turned." And not less ominous was the sort of demand that now began being made by His Britannic Majesty's diplomatic representatives at various courts, that in view of the outcome of the war they were entitled to the precedence over His Most Christian Majesty's representatives. French pride could not possibly have been flouted more shrewdly. ${ }^{2 ?}$

How, then, was France to recover her prestige and the influence that this assured her upon Continental affairs? 'This was the question that addressed itself, and in terms ever more poignant, to the guardians of her diplomacy in the period between the 'Treaty of Paris and the death of Lonis XV. And the answer returned to this question by all schools of opinion on questions diplomatic carried with them the implication at least that, before France could hope to regain her station in Europe, English power must be diminished. 'The story however is one that should be Ib., VI. 183-7; VII. 26-7. 
told in more detail, and in comnection with it $\mathbf{I}$ desire to draw particular attention to two highly important documents: Choiseul's Mémoire of February, 1765, which comprises a general defense of his policy," and Broglie's Conjectures Raisonnes of 1773 , which voices the views at that date of an adherent of the more narrowly Continental viewpoint. ${ }^{31}$

Choiseul begins his exposition of the fundamentals of French diplonacy by tracing the calamities of the late war to one cause: the fact that the Austrian alliance was allowed to convert "the war on seas and in America, which was the true war," to a purely land war. Also it is admitted that the Austrian connection was always bound to be a precarious one. Nevertheless, it is insisted, it was of value as tending to conserve the peace on the Continent, for which reason it should be continued so long as it exacted no further material sacrifices by France. And the historical connections with the princes of the Empire should be viewed in the same light. 'The old policy of paying subsidies in advance should be discontinued. The English system was to pay for services rendered and this

\footnotetext{
* Soulange-Bodin, La Diplomatie de Louis $\mathrm{XV}$ et le Pacte de Famille (Paris, 1894), 236-53.

s" "Conjectures Raisonnées sur la Siluation actuelle de la France dans le Système politique," etc.: "Ocuvre dirigé par de Broglie et exécuté par M. Favier": dated Apr. 16, 1773, and comprising vol. 1. p. 211 to the end, all of vol. II, and vol. III. to p. 104 of Ségur's politique de tous les ('abinets, (1801). Cited hereafter as "Ségur."
} 
had proved much more effectual. But the one indispensable alliance of His Most Christian Majesty was with His Catholic Majesty. The foremost precept of His Majesty's policy henceforth must be, accordingly, "to manage with the most scrupulous attention his system of alliance with Spain, to regard the Spanish power as a power necessary to France." Nor would this be difficult, for the king of Spain was "just, firm, and one upon whom you can count eren berond the point at which France herself wonld fail you." 'The Mémoire concludes thus:

It remains for me to speak to Your Majesty of the maritime powers. England is the declared enemy of your power and of your state, and she will be so always. Many ages must elapse before a durable peace can be istablished with this state, which looks forward to the supremacy in the four quarters of the globe. Only the recolution which will occur some day in America, though iec shall probably not see it, will put England back to that state of wealness in which Europe will haz'e no more to fear of her.

'Thus the Mémoire closed on something like a note of despair. Despair, however, was not Choiseul's normal attitude. Even a year before this he had sent an agent named Pontleroy to British North Americal to report upon its resonrces and the strength of the lines comnecting it with the mother-comtry, ${ }^{32}$ and now in 1766,

:- (. De Witt, Thomas Jefferson, Etude historique sur la Dé 
with the news of the American outbreak against the Stamp Act at liand, the results of Pontleroy's investigation and their significance for France became the subject of active correspondence between Choisenl and IIis Most Christian Majesty's representatives at the Court of St. James.

Judging from the small number of arrangements with reference to colonial possessions in America [10 rand wrote ('hoiseul in August, 176r] Burope has only lately begun to sense their importance. Engliand herself has discovered with surprise that they are the sourecs of the power which she enjoys and that these great objects of power and ambition draw in their wake the balince of power in Europe. In brief, money has become so necensary to the sustenance of a government that without commerce no state has the wherewithal to uphold its dignity and independence; and commerce would dry up if it were not sustained by that branch of it which traflies in the products of Americat. It is there that England finds the outhet for her manufactures, and to what dimensions would these be reduced if they supplied only the market of Europe at a time when every nation is endearoring to make its own resources suffice and to prevent the departure of specie from its territory ?:?

This. of eourse, is all in the best strain of the most rigorous Mercantilism. Nevertheless, promoratip ambromine (3rol ed., Paris, 1861), 40\%. Most of the citations to this work are to the documents in the Appendices, Pp. 393-j.59. See aho l'. Kitpp, Life of Kall (N. Y., 1860), 13-1.

3. De Witt, "pp. rit.. I. 1.20-1. See also to same reffect pp. 427-8. Choiculs viewpoint was precisely the same: $i 6 ., 17-51$. 
fessing to fear the American colonies more than England herself, Durand advised against fomenting revolution anong them, since to do so "might have the result of handing over the other colonies of Europe to those who by their excessive energy and strength had detached themselves from the parent stem."34 Durand's successor Chatelet, on the other hand, was strongly of the opinion that France ought to seize the first opportunity of intervening in America.

In the ase of a rupture the inquired of ('hoiseul early in December. $176 \%$ even were it an open and premature one, between the eolonies and Great Britain, could France and spain remain idle spectators of an opportunity which in probability would never oceur again? . Before six months have clapsed America will be on tire at every point. The question then is whether the colonists have the means of feeting it without the aid of a foreign war, and whether France and spain should run the risk of taking an active part in fomenting the confliet and making it inextinguishable, or whether it would be more their policy to leave it to itself at the risk of its going out for want of fuel and the means of spreading. ${ }^{35}$

As a matter of fact Choiseul had already taken a definite step toward interesting his government in the American situation. (On April 2:2nd, 1767,

* 16., 5:?. Sice also, to some effert, pp. 43:-3.

* 16 ., 56-7 footnole. Choiseul regarded these views as "profound": $i b$. For further correspondence to the same effect, see ib.. 433-55. 
le had despateded Kall, who was hater he distinguish himself as a mator-gencral in Washington's army, to Amstcram, there to inguire into "the rumers in circulation about the English colonies" and, shombd these be well foumded, to "make preparations for a jourmey to Americas." In conformity with these and lurther instructions, Kall, finally sailed for Ameriea from (iravesend, on Octolser the and arrived in Philadelphia Jamoary 2nd. In essence, the conclusions he drew from his inguries into the American situation were, that the moment had not yet arrived for le rances to embroil herself with her neighbors; that while the remoteness of the American population from their econtral govermment made them "free and coterprising," at bottom they were "but little inclined to shake off the English supremacy with the aid of foreign powers"; that "such an alliance would appear to them to be fraught with danger to their liberties"; that "at war with us would only hasten their reconciliation," so that "on the fonting of restored privileges, the English court could even direct all the troops, resentres, and ships of this part of the world against our islands and the Spanish Main.

There can be little dombt that these observations, in the general assessment they made of American sentiment, squared with the lacts, but

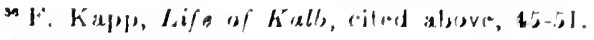

"Ib., 5:3-7 pexsim
} 
that was small consolation to Choiseul, who in his disappointment petulantly charged Kalb with superficiality and pronounced his labors useless. ${ }^{3 s}$ The result however was that now, abandoning any idea of acturally interfering in America, the French minister began to formulate a plan whereby France and Spain should indirectly foster discontent in the English colonies by throwing open the ports of their own colonies to the products of North America. ${ }^{39}$ This was on the basis of the theory, that while the English colonies augmented the strength of England, those of France weakened her. "The thing to be aimed at," therefore, in the words of M. Abeille, Choiseul's secretary-general of Conmerce, was "to diminish the artificial strength of England and to reliere France of the burdens that obstruct the development of her native strength." ${ }^{+0}$ Indeed M. Abeille was for granting the French colonies their independence. But these views naturally encountered some opposition at Madrid; and in 1770 Choiseul fell from power.

${ }^{3} I b$, , 71. At this very time Franklin was writing, with reference to Choiseul's policy: "That intriguing nation would like very well to blow up the coals hetween Britain and her colonies, but I hope we shall give them no opportunity," Bancroft, III. 261. As late as $\Lambda$ pr. 6, 1773, Franklin predicted that a war with France and Spain on the part of England would heal the breach with the colonies, Complete Works (Ed. Bigelow), V. 126.

De Witt, op. cit., 60-3.

4t $I 6,61-2$. 
'Two years later oceurred the first partition of Poland. all things considered, the most humiliating episode from the French point of view in the history of French diplomacy. Poland had been for centuries, with a fair legree of enstancy, the ally and protégé of France. Since 1745, moreover, L ouis himself had been endearoring, through the st bterrancan chamels of the secret du Roi, w rich indeed he had created for the purpose. to secure the suecession of the IIouse of Conti. to the Polish throne. ${ }^{+1}$ 'The project of the royal brigands, however, was never known to Mis Most Christian Majesty's agents till it was fait accom$p l i$, and thus the most important transfer of territory since the Peace of Westphalia, involving ultimately the extinction of the greatest state territorially in western Europe, was effected not only without the consent but without the knowledge of France. But worst of all, France's own ally Austria was particeps criminis to the act, even though a reluctant one at first. "She wept but she took," was the adequate aceount that Frederick gave of the empress' part in the transaction. Her course published to the world at large in a way that tears more copious and more sincere than hers could not obliterate, that the desires of France no longer greatly counted in Europe. ${ }^{42}$

${ }^{41}$ J aviuse at Rambaud, op. cit., VII. 212-14.

42 111 ., 503-11. 
"The 'Tragedy of the North" it was that incited Broglie, the principal agent of the Secret du Roi, to the composition, in collaboration with the versatile Favier, of his elaborate Conjectures Raisonnées, referred to above. "One would wish in vain," this document begins, "to conceal the rapid degradation of the credit of France in the cour's of Europe, not only in consideration but even $n$ dignity. From the primacy among great powers she has been forced to descend to a passive rĉle or that of an inferior." +3 Putting then the question as to the cause of this unhappy transformation, Broglie first assailed "the change of system produced by the 'Treaty of Versailles." 44 The preponderance in Europe was the rightful patrimony of the French crown: this was a dogma consecrated by a thousand years. ${ }^{45}$ But the Treaty of Versailles had accustomed Europe "to regard France as . . . subject to orders from Austria." 'To the same cause was it due that France had abandoned her ancient allies Swed,en, Poland, Turkey, and the German princes; and worse still, that she had made to fill the rôle of dupe in the recent developments in Poland and Turkey, the result of which was her own reduction to the fourth grade of powers. ${ }^{45}$ The Farnily

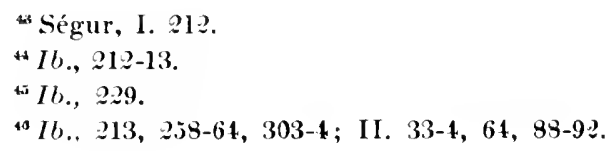


Compact of $176 \%$, too, had had the worst possible effect upon European opinion, since by it Spain was admitted to virtual equality with France. "France for the first time admitted the equality of another power." 4 ir

Thus far spoke the critic and rival of Choiseul. 'The longest section of the Conjectures however deals with England and the tone here is significantly harmonious with that of Choiseul's Mémoire. The attitude of England toward France was that of ancient Rome toward Carthage. England of course did not expect to wipe out the French monarchy; her inferiority on land forbade. the idea. But she had adopted the principle of keeping the French marine reduced, "of watching our ports, of surveying our dockyards and arsenals, of spoiling our projects, our preparations, our least movements." Her poliey in this respect was to be explained in part by that spirit of rapine native to the English people, but also in part by the knowledge of the English ministers that the edifice of English power was still supported by factitious resources and forced means and that its natural tendency, in face of the approaching danger of a schism between the nother-country and her colonies, would be to crumble and dissolve. In short, it was fear that determined England's policy toward Franee, though a fear that knew how to choose its weapons. In view of this

"Ib., I. 229-30. 
fact, France should know her real strength, should know that her industry, resources, patriotism, and intelligence were sufficient to overturn "the colossus of English power," could she once restore her marine. She should know too that the feeble line of conduct taken with England in the inmediate past had but nourished English pride and disdain and that what was needed was a firm line of conduct. Franee's military system and her diplomatic policy must alike sustain the dignity and preëminence of the crown of France on sea as well as on land. ${ }^{\text {t }}$

The influence of the Conjectures Raisonness upon those who were interested in France's diplomatic position is beyond all question, and the same is true of Abbé Raynal's contemporaneous Histoire des Indes." "The marine," declared this writer, "is a new kind of power which has given, in some sort, the universe to Europe. 'This part of the globe, which is so limited, as acquired, by means of its fleet, an unlimited empire over the rest, so extended." Yet the benefit of this control had passed, in effect, to one nation alone, England, and with it had passed the balance of power. Such had not always been the case. In the days of Louis XIV France had

45 16 ., II. 165-97.

${ }^{43}$ Sorel, op. cil.. I. 304-10. "I a doctrine de Favier se ramène à une proposition essentielle: lancantissement de l'Angleterre," $i b$. , 306. 
given the law to kurope, and the basis of her ereatness had been in her marine. Infortumately, the excesses of that momarch, while cementing the alliance of the maritine states against France, had also turned the martial energies of the latter from the fleet to the anny; and so French power had been donbly modermined." The comnection between England's greatness as at colonial power and her influence anomg the states of the world and the memory of lerance's greatness under lonis XIV are constantly reiterated thoughts in Raynal's pages, and the course to which they incited rrench sentiment, both official and unofficial, is plain. "Favier," writes Sorel, "made disciples and Raynat proselytes." "is

France's intervention in the American Revolution is often described as an act of Revenge. 'The description is less erroneous than incomplete, for while it calls to mind the fact that France had humiliations to be redressed, it fails to indicate the even more important lact that she had also a róle to be retrieved. Furthermore, it leaves entirely out of account the logic by which, in an Age of Reason, the purpose of either revenge or restoration was brought into relation with a concrete situation. 'This logie comprised the follow-

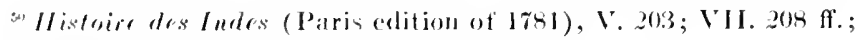
JX. in ff., 219 ff.; and especiatly, X. $136 \mathrm{ff}$.

"Sisrel, "p. rit., I. 300 . 
ing ideas: That France was entitled by her wealth, power, and history, to the preponderating influence in Continental affairs; that she had lost this position of influence largely on account of Great Britain's intermeddling; that Great Britain had been enabled to mingle in Continental concerns by virtue of her great naval strength, her commercial prosperity, and her preparedness to maintain Continental subsidiaries; that these in turn were due in great part to her American colonial empire and especially to the policies controlling her trade therewith; that America, become independent, would be an almost total loss from the point of view of British interests; that this loss would mean a corresponding diminution of British power; that since the two were rivals, whatever abased the power of Great Britain would elevate the power of France. By calling into existence the New World, France would "redress the balance of the Old."

But while these ideas define the principal advantage which France hoped to obtain from the course she took, there were also supporting ideas that should not be lost to view. For one thing, it was by no means impossible that whether she intervened or not in behalf of the American rebels, France would find herself, sooner or later, at war with Great Britain in defense of the French West Indies. Again, it had for centuries been France's rôle to back the smaller fry against 
her greater rivals. Again, it was generally felt that, formidable as it was at the moment, British power was in reality more or less spurious. Furthermore, recent diplomatic developments had most miraculously paved the way for French intervention in North America. The withdrawal of France from Canada had left America no reason to fear her; the Family Compact convenanted the assistance of the Spanish marine; the Austrian alliance constituted a reasonable guaranty of peace on the Continent. Finally, it was felt to be not only allowable but right for France to seize so favorable an opportunity to tear down a power that had been used so outrageously as England had used her power on the sea. In the end, the project did not lack some of the aspects of a crusade.

The primary requisite, however, to an understanding of Louis XVI's espousal of the cause of American independence is that due weight be given the fact that Europe was still organized on the dymastic principle, and to the further fact, especially noteworthy in the case of the elder branch of the House of Bourbon, that position and influence were the essential objectives of diplomacy, even in the age of "Benevolent Monarchy." ${ }_{52}$ To-day with the voice of the common

${ }^{2}$ Indeed among a people so fond of glory as the French the very security of the crown demanded that the dishonor it had suffered abroad in the detested latter years of Louis XV should be wiped 
man dominant in the direction of society, historical investigators are apt to give too slighting attention to all but bread-and-butter interests as interpretative of the conduct of states. But this is plain anachronism. 'The doctrine of the equal-

away as speedily as possible. "Or la France, passionnée comme (lle était pour la gloire, et qui aurait excusé bien les fautes du gonvernement intéricur, ne pardonna pas au Roi . . son humiliation." lavisse, Histoire de France, VIII. 411 . It is interesting to note that as early as November, 1775, Burke had predicted French intervention. "He olserved, that from being the first, she was, with regard to effective military power, only the fifth state in Europe. That she was fallen below her former rank solely from the advantages we had oltained over her; and that if she conld humble us, she would certainly recover her situation." Parl. Hist., XVIII. 967. Eighteen nonths before this Col. Barré in the debate in Commons on the "Bill for Regulating the Government of Massachusett's l bay," had declared that "during these troubles with our colonies, lrance would not lie quiet," ib.. XVII. 130\%. A hint of foreign interference is conveyed in Franklin's "Rukes by Which a Great Empire May Be Reduced to a Small One," Works (Ed. Sparks), IV. 396. In a sermon delivered June 6. 17rt, in the Second Church of Boston, the Rev. John Iathrop declared, "France and Spain will take satisfaction for their losses in the late War," Pennsyleania Packet. No. 147. In his "Farmer Refuted," which was published in Feb., 17z5, Hamilton put the question whether "the ancient rivals and enemies of Great Britain would be idle," in the event of an open breach between Great Britain and her colonies; and answered, that ere this conld eome about, "the French, from being it jealous, politic, and enterprising people, must be grown negligent, stupia, and inattentive to their own interest. They could never have a fairer opportunity or a greater temptation to aggrandize themselves and trimmp over Great Britain than would here be presented." Works (Constitutional Ed.), I. 161-5. A year later Jolu Adams raised the same (fuestion on the floor of Congress (Mar. 1, 17f6). "Is it," he inquired, "the interest of linace to stand neuter, to 
ity of man was indeed a tenet of the schools in 1776. hut it had made little headway among the professional diplomatists, who still assessed the rencral welfare in terms fumished by the competition for station of rival reigning houses. ${ }^{3}$

join with Britain, or to join will the colonies? Is it not her interest to dismember the British empire? Will her dominions be sate if Britain and Imerica remain comnected? Can sle preserve her possessions in the Went Indies?. . In case a reeonciliation shomlat take place between Britain and Anerical, and a war should hreak ont between Britain and Fance would not all ber inland be taken from her in six months:" Life and II orks, II. 1si-s. There was, of course, a strong posibility, even probability, of such a reconciliation at this date. For this and other reasons the danger to France eited by Adams was mueh more real than after saratogil. See infro. Malams, at this date, wished only a "commercial" connection with France, and deelared flatly against a "politieal" or "military" connection. "Receive no troops from her," he advined, $i$, For some further items on American expectation of lench aid because of the rivalry between France and

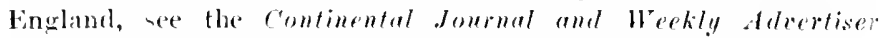
of Boston, isues of July 11, 18, and 25, and Oct. 17, 17\%6.

${ }^{5 ?}$ see further the document given in sppendix II. 


\section{CHAP'TER III}

VERGENNES DISCOVERS THE AMERICAN REVOLT

Louis XVI ascended the throne in May, 1774, and was at once confronted with the task of choosing a ministry. The queen, anxious to see the policy of friendship with Austria continued, urged that Choiseul be again called to power. The dull and priggish Louis, however, abhorred both the aggressive talents and tawdry morals of the former minister, and his scruples carried the day. When the new cabinet was formed in the course of June and July the post of chief-minister was assigned to the old and decrepit Count de Maurepas, while that of secretary of state for Foreign Affairs was bestowed upon the Count de Vergennes. ${ }^{1}$

Charles Gravier, later the Count de Vergennes, was born at Dijon, in 1717, of one of those families of the lesser noblesse whose function it was, under the Old Régime, to replenish the ranks of French officialdom. He began his diplomatic career in $\mathbf{1 7 4 0} \mathrm{by}$ accompanying his uncle Chavigny to the latter's post as ambassador at Libson.

\footnotetext{
${ }^{1}$ I avisse, Histuire de France, IX. ${ }^{1}$ 5, 6.
} 
Six years later he won the praise of Argenson by the clarity of his views on questions then at issue between P'ortugal and Spain. In $\mathbf{1 7 5 0}$ he became minister plenipotentiary at 'Trèves, and a little later His Most Christian Majesty's representative at the Congress of Hanover, where he is said to have shown great dexterity in foiling the designs of George II's representative, the Duke of Newcastle. 'This and other suecesses brought him four years later the great post of ambassador to Constantinople, where for fourteen years he represented both the official diplomacy and the Secret du Roi. 'Then followed a short term of retirement on account of an altercation with Choisetul. But in 1771, at the instance of Aiguillon, he became the king's ambassador at Stockholm; and here the year following he successfully engineered a coup d'ctat, which by transferring the governing power in Sweden from the antiquated and corrupt estates to the king, saved that country from the fate which had just overtaken Poland and was even then overshadowing Turkey.2

"La craude Euryclopidir, title "Vergennes"; Magazine of American History, XIII, 31 ff.; Flassan, op. rit., VI. 12-13, 934-58; Arthur Hassall, The Balance of Power (N. Y., Is9s), passim; l.e Bonneville de 11 arsangy, Le Cherulier de Jergenues, son Ambassade à Constantinople (2 Vols.; Paris, 1894); H. Doniol, "I.e Ministere des Affaires itrangieses de France sous Ie Comte de vergennes," Reve dllistoire diplomatique, VII. 528-60 (1503). 'This reference is dhiefly valuable for the extracts it contains from "..e "sonenirs" of Vergennes" friend Ilennin, written at the time 
Compared with the brilliant Choiseul, the new secretary is a somewhat prosaic figure, an impression which Carlyle has recorded in the dictum that "M. de Vergennes was a clerk, a mere clerk with his feet under the table." The fact is that, to a taste for methodical employment, and to the minute knowledge of the diplomatic systems of Europe that stirred the admiration of Ségur, Vergennes added an ambition for patriotic achievement that was none the less real because it was controlled by the prudence of a man who had risen to station by his own efforts. Nor is the traditional Vergennes less remote from fact, the Vergennes who is pictured to us as "a difficult and dangerous man with whom to have dealings," a washed-out version of the legendary Machiavelli. It is certain that Vergenne's was no sentimentalist, for which, however, he is hardly to be blamed, since the happy thought of blending sentimentalism and diplomacy had not yet occurred to men. On the other hand, the Machiavellian principle that self-interest is the only feasible basis of a public policy was applied by him with certain very essential qualifications and limitations. England, it is true, he treated from the outset to a policy of duplicity and falsehood, but that nation, he held, had put herself beyond the

of the minister's death. See also a eulogy of Vergennes' Continental policy by Sorel in the Revue historique, $\mathrm{XV}$. $273 \mathrm{ff}$., and a criticism of the same by Tratchersky, $i b .$, XVI. 397 ff. 
pale. On the Continent itself he sought unremittingly to bulwark the status quo behind the maxims of the système de Conservation. "Force," he wrote, "can never rest a title, nor convenience bestow a right"; and the partition of Poland he denounced as "political brigandage." Moreover, he regarded the honor of the king as setting very definite limits beyond which political advantage was not to be sought. Capable himself of playing the Jesuit with most admired skill when occasion required, yet once the word of His Majesty was distinctly pledged, he deemed it inviolable.

In a word, expert that he was in the use of the conventional weapons of eighteenth century French diplomacy, Vergennes had no thought of casting these aside or of greatly changing them. And the same is true of his attitude toward the accepted axioms of his profession. He believed in the doctrine of the Balance of Power, and till he was disillusioned by the results of the American Revolution, in the tenets of Mercantilism. He adopted without reservation the fundamental postulate of the Classical System, that France by virtue of geographical position, wealth, intelligence, and military resources, was entitled to the preponderance in Europe. "France," he wrote in 1778, "placed in the center of Europe has the right to influence all great affairs. Her king, comparable to a supreme judge, is entitled 
to regard his throne as a tribunal set up by Providence to make respected the rights and properties of sovereigns." ${ }^{3}$ Alas! in 1774, the age-long prerogative of France was in eclipse, her prestige dimmed. "Among all nations," he afterward declared of this period,

the opinion prevailed that France no longer had either will or resources. The envy which till then had governed the policy of other courts toward France became contempt. The cabinet of Versailles had neither influence nor credit in any quarter. Instead of being, as formerly, the center of all great affairs, it became their idle spectator. Everywhere men treated its approval and its disapproval as alike negligible. ${ }^{4}$

It was a situation that touched him hardly less acutely than if it had been his own personal misfortune.

How, then, was France to recover her influence and what use would she make of it, once it was recovered? Like Argenson, Vergennes linked the reputation of the House of Bourbon with the cause of Continental peace.

${ }^{3}$ Mémoire of Apr. 18, 1778, Flassan V'I. $140 \mathrm{ffg}$. See also Recueil des Instructions, I. (Autriche), 488. See SMSS., No. 861, where Vergennes compares the wealth of France and Great Britain favorably to France. At the same time he envied the British government the facility with which it commanded the resources of the realm. "Nous avons assurement," he wrote, "des resources plus reelles que l'Angleterre, mais il s'en faut bien que le jeu en soit aussi facile. Cela tient à une opinion qui ne peut pas sétablir dans me monarchie ahsolue comme dans une monarchie mixte." Doniol, 11. 18 .

4 Ib., I. 3-4. See also Sorel, op. cit., I. 309. 
Like Broglie, he censured the overestimation of the Austrian connection that had eventuated in neglect of France's guardianship of the Peace of Westphalia, "one of the most beautiful jewels" of the Gallic crown. On the other hand, following Choiseul, he admitted that the Austrian alliance, kept within due bounds, might yet prove useful to France in that its tendency was to prevent England and Austria from striking hands once more. It thus guaranteed, he argued, the peace of the Continent, where France could desire only peace, and, by the same sign, it left France at liberty "to direct her efforts to counterbalancing the power of England, whose naval superiority most necessarily enlisted her foresight." Finally, from the same point of view, The acclaimed the Family Compact as the very "cornerstone of France's whole system." This connection, it was true, required France always to stand ready to come to the defense of Spain's rast possessions beyond the sea, but it was, for all that, more valuable to France than to Spain. England was loath to break with Spain on account of her profitable commerce there, from which she drew riches and employment, while with France no such motive held her back. "If there is anything capable of giving England pause, it is the thought of France and Spain uniterl; it is the certainty that the first camnon- 
shot directed at the one or the other will be answered by both.". 5

None the less, it would seem that at the moment of taking office Vergennes' policy looked toward an effort at amity with England; and it is certain that he first assessed the American revolt as guaranteeing England's continued peaceableness rather than as furnishing a fulcrum for an actively anti-English policy. ${ }^{6}$ For this there were three reasons: In the first place, the American business itself was still much "in the vague." Again, Vergennes was aware that Louis had taken the throne pledged to a program of economy and internal reform and to this program, he naturally assumed, diplomatic programs would have to be subordinated.' Finally, in July, 1774, by the Treaty of Kutchuk-Kainardji Russia had established herself on the shores of the Black Sea in territory wrested from Turkey. Alarmed at the prospect of a repetition of what had just occurred in Poland, as well as for France's monopoly of the Levantine trade, Vergennes felt that his first attention must be given to the South-

"Instructions to the Baron de Breteuil," Dec. 28, 1774, Recueil des Instructions, I. $478 \mathrm{ffg}$; "Exposé succinct" of Dec. 8, 1774, Doniol I. 14 ff.

- $1 b .$, I. 13,40 .

${ }^{7}$ See Recueil des Instructions, I. 488: "La grandeur de la puissance du Roi, la position de ses États et ses soins que sa Majesté est résolvé de donner à leur administration intérieure, le mettront en effet... en état de choisir entre tous les systèmes politiques celui qui conviendra le mieux à ses vues et à ses interêts." 
eastern situation. Indeed, he seems at one moment to have considered the possibility of persuading England herself to join in an effort to curb Russia's assaults upon the established equilibrium.s

But this attitude was, after all, weakly rooted in a thin soil. Moreover, 'Turkey's cession of the Chersonese was soon seen to be fait accompli. Vergennes' real disposition toward England found expression in connection with the dispute which began brewing in $\mathbf{J u l y , ~ 1 7 7 4 , ~ b e t w e e n ~ S p a i n ~}$ and Portugal over some aggressions of the latter in South America. 'The possibility of war between Portugal and Spain raised the possibility of war between Spain and England and that, in turn, the possibility of war between England and France. Commenting on the report that England desired an amicable settlement of the affair, Vergennes remarked: "We share the wish, rather from necessity than inelination.", And equally illuminative is an episode which occurred early in $\mathbf{1 7 7 5}$ in connection with the destruction which the king had just then ordered of the correspondence of the Secret du Roi. Among the paper's about to be consigned to the flames was a plan that had been drawn up by Broglie in 1766 for the invasion of England. Vergennes

* See Hassall, The Balance of Power, 320 ; Recueil des Instruclions. IX. (Russe), 318-20; and Doniol, I. 15.

'Vergennes to Ossun, Oct. 31, 177.t, Doniol, 1. 33. 
and his associate, the Count du Muy, at once petitioned Louis to be allowed to save this document, a request which was promptly granted. ${ }^{10}$

But all other sources of instruction as to the new secretary's attitude toward England yield place to a document I have already cited more than once, his Exposé Succinct, which was prepared early in December, 1774. This was, in brief, a plea for military preparation based on a survey of the whole diplomatic situation with which France was then confronted. "People," its author wrote, "respect a nation which they see prepared to make a vigorous resistance and which, without abusing the superiority of its forces, desires only that which is just and useful for the whole world, to wit, peace and general tranquillity." Unfortunately, however, while this was the objective of diplomacy, diplomacy itself was unable "to fix conclusively the choice of route thereto." It was a truth albeit a trite one,

that the longer a peace has endured the less likely is it to continue. The fact that the present peace has lasted twelve years furnishes a strong prejudgment against its further stability. It is then not to transgress the limits of allowable prevision to insist upon the necessity of being ready for any event; and besides, one is never better assured of peace than when one is in position not to fear war. Opinion, 'tis said, is queen of the world. ${ }^{11}$

${ }^{10}$ Ségur, 1. 104-6; Doniol, I. 93-4.

"Ségur, 1. 169-70; Doniol, I. 20. 
Nor did Vergennes leave those whom he addressed in doubt as to the practical bearing in the main of these generalizations:

If the wrote] having surveyed the Continent we turn our eyes coastward, do we find there greater pledges of security? We see lying alongside us a nation greedy, restless, more jealous of the prosperity of its neighbors than awake to its own happiness, powerfully armed and ready to strike on the instant. Let us not deceive ourselves; whatever parade the English ministers may make of their pacific intentions, we cannot count upon this disposition longer than their domestic difficulties continue. These however may come to an end, or indeed they may increase to such a point as to cause the government to direct the general uneasiness against objects abroad. It is not without precedent that the cry of a war against France has become the rallying point of all parties in England. ... Having nothing to gain with France by the prosecution of a legitimate commerce, England looks with eny upon the vast extent of our plantations in America and our industry in Europe."

Rarely has a minister of state drawn a more sinister picture of the purposes and policies of an ostensibly friendly government; and to the picture so delineated, rumor soon added the touch of imminent menace. Within a few days of the preparation of the Exposé, Vergennes received

$12 / 6, ., 19-9$. Note the point of view revealed by the assertion that Fngland has nothing to gain from "a legitimate commerce with France," 
from Garnier the report then circulating about London that Chatham had a plan by which peace could be reëstablished in America without offense to the dignity of England. 'This plan, he at once inferred, could only be at the expense of France. 'True, he wrote Garnier, England was burdened with debts and was the object of universal emmity. True too, George III has little love for Chatham. But the very extremity of the situation in America might compel his Britannic Majesty to conquer his prejudices and call this "enemy of peace" to power once more. His doing so would signal a situation for which desperate remedies had been determined upon and France would have need to beware. ${ }^{13}$ Six weeks later Garnier wrote still more alarmingly. Speaking on his own responsibility, he asserted very confidently that if the measures of the existing ministry "do not meet with complete success, the end of the administration will follow immediately and the king will be forced to yield to circumstances and place my lord Chatham at the head of affairs. He will come in clothed with absolute power."14

There now ensued a considerable pause; and it was the end of July, 1775, when the Count de Guines wrote that Lord Rochford, a member of the British ministry, had confided to him the belief of men in both parties, that the only way

12 Vergennes to Garnjer, Dec. 26, 1774, ib., 60-2.

"Ib., 69. 
to end the war in Anerica was to declare war upon France, the argument being that, if confronted with the necessity of choosing between England and France, the Americans in fear of seeing the latter once more in Canada would certainly cast in their lot with the former, even at the expense of liberty. ${ }^{15}$ A little later advices reached Vergennes by way of Madrid that, even though Chathan did not eome again to powerwhich was improbable - the existing ministers seemed to wish to imitate his way of thinking, from which it resulted that war was not unlikely to break out at the least expected moment. ${ }^{16}$ Finally in the middle of September Vergennes sent Beammarchais, the famous author of Figaro, to pump from Rochford, who was an old aequaintance of his, further information as to British intentions. Beatumarchais, in a letter which was handed the king September 21st, summarized his conchusions thus: "In short, America is lost to the British in spite of their efforts. The war is waged more ferociously in London than in Boston. 'The crisis will end with war against Franee if the opposition comes in, whether it is Chatham or Rockingham who replaces Lord North.",

16. It. $116-17$.

16.. 117-19. See also the letter of $\Lambda$ ug. $\tau$ from I.ouis to Charles IIl, indicating the former's persuasion of the possibility of war with lengland, ib., 131-2.

${ }^{17}$ John Durand (Ed.), Doruments on the American Revolution (X. Y., 1889$), 53-4$ 
Already, however, the secretary's interest in the American situation had ceased to be exclusively one of alarmed concern. 'Thus, late in August the ambassador had forwarded from London the text of the royal proclamation pronouncing the Americans "rebels," and Vergennes had concluded thence that, so long as the existing ministry remained in office, there was little danger of an alliance between America reconciled and the mother-country, which would turn its combined forces against France and Spain. ${ }^{18}$ Furthermore, the little likelihood there had been at any time that the arch-enemy of France would come again to power was for the time being at an end. This great man, "the world forgetting, by the world forgot," was now in a mysterious seclusion from which he did not emerge till the beginning of $177 \pi$. For many months the name of Chatham, its magic in abeyance, drops out of the despatches altogether. ${ }^{13^{i}}$

A clue to the new point of view of the Foreign Office is afforded by its response to Guines' despatch of September 8th, reporting a statement by Rochford that the American Lee, now in London, had sworn "on his honor" that the colonists had assurance of aid from France and Spain, and his own positive denial that this

${ }^{13}$ Doniol, I. 172-t.

19. The Correspondence of King George the Third with Lord North, from 1768 to 1783. (Ed. W. B. Donne, London, 1867, \& vols.), II. I0. 
statement had hasis in fact. Replying ten days later Vergennes had commended the ambassador's method of parrying his English interlocutor but at the same time had cautioned him against putting anything in writing. "The king," said he, "wishes neither to augment the difficulties of the British government nor to encourage the resistance of the Americans, but neither does it suit his interest to serve as a means of putting the latter down." "19

Late in October Vergennes received the British ambassador Stornont and engaged him in an extended conversation on the American situation with the aim, at once, of reassuring the English government as to French intentions and of discovering how seriously that government regarded its trans-Atlantic affairs. That which was now happening in America, the French secretary declared, he had himself foreseen when as ambassador at Constantinople he had learned of the cession of Canada to England. He then proceeded to suggest that what the Americans were plainly aiming at was independence and to conjecture the consequences should they attain their object:

In that case they nould immediately set about forming a great marine, and as the y have every possible advantage for ship-building, [it] would not be long before they had such flects as would be an overmatch for the

"Doniol, 1. 150-1. 
whole naval power of Europe, could it be united against them. . . . In the end they would not leave a foot of that hemisphere in the possession of any European power.

To these speculations the Englishman assented eagerly. ${ }^{20}$ It is evident that against the background furnished by the siege of Boston, the news of which was already producing an immense stir in Paris, Choiseul's observation that "the balance of power lay in America" revealed a new significance.

In the closing days of 1775 the French Foreign Office proceeded, under Vergennes' direction, to formulate the problem with which the American revolt confronted France. It had before it memoirs and letters from a variety of quarters, some even from the French West Indies, but what is much more to the point, it had before it the plans and projects of Choiseul, wherein was clearly set forth the connection that existed between the American insurrection and the restoration of French power and prestige, and wherein the large general problem was reduced to the more precise question whether the Americans would really proclaim their independence, or if they once proclaimed it, be of a mind to make a persistent effort for it. ${ }^{21}$

2" SMISS., No. 1306.

$\approx$ Doniol, 1. 240-2. Vergennes had, upon taking office, reorganized the archives of the Foreign Office, and had had his secretaries 
The answer that the Foreign Office returned to this question and the consequences that it deduced from its answer are set forth in the Reflexions, which was penned by Vergennes' secretary, Gérard de Rayneval, probably early in November, 1775." "There is reason to believe," this most important document begins, "that the colonies are not in quest simply of a redress of grievances, but that they are resolved to throw off the roke of the mother-country altogether." Yet, it continues, "if the colonies are left to themselves, it is probable that Great Britain will succeed in subjugating them." What then is the course that France should pursue at this juncture? "If England subjugates the colonies she will at least retain the commercial benefits that she has always drawn thence and which will accordingly continue to sustain both her manufactures and her marine. She will, moreover, prevent the colonies from becoming what they would be if independent, a considerable weight in the balance of power in favor of some other state." France's interest was therefore plain. "England is the natural enemy of France, and a greedy, ambitious, unjust, and

prepare elaborate summaries of French foreign policy in all directions from the time of the Peace of Westphalia, Rome d'Iistoire diplomatique, VII. 540.

211 ., 243-9; SMSS., No. 1310. The conjecture as to date is based on M. Doniol's very probable theory that Beaumarchais' activities in behalf of the idea of secret aid came after the seeretary had formulated his program in the "Réflexions": see Doniol I. 251. 
treacherous enemy, the constant and cherished object of whose system is, if not the destruction of France, at least her abasement, humiliation, and ruin." But now at this moment, England's "colonies are in open war against her, their purpose is to cast off her yoke, they ask us to furnish them aid and supplies." Suppose then we meet their desires and our assistance proves effective, what advantages will result to us?

1. The power of England will shrink and ours will expand correspondingly; 2. Her commerce will suffer an irreparable loss while ours will increase; 3 . It is very probable that in the course of events we may be able to recover some of the possessions that the English ridded us of in America, as for instance, the Newfoundland fisheries, those of the gulf of St. Lawrence, the Isle Royal, etc. I do not speak of Canada. ${ }^{23}$

But if these were the premises upon which France should base her course, what precisely should that course be? Of men capable and willing to bear arms the colonies had a great sufficiency, but they lacked: "first, provisions of war; secondly, currency; thirdly, a good navy." To obtain the first it would only be necessary for them to send their vessels to French ports laden with produce which they should there exchange for arms and munitions. 'This commerce could easily proceed without the government having any visible hand in it: "it would only be necessary

${ }^{23} I b ., 243-4$. 
to have at each of the ports to which the American vessels resorted an intelligent merchant whose loyalty and discretion could be relied upon." 'The demand for money was somewhat more difficult, but given legitimate dimensions, it could be met in the same way as the demand for mumitions. Most difficult of all would it be to furnish the insurgents ressels of war without declaring openly for them and so "precipitating war with Great Britain." Still it would perhaps be feasible to send some merchant vessels adapted to the uses of war to Santo Domingo, where they could pass to the Americans by a simulated purchase. But the essential thing was that France should lose no time in reinforcing the courage of the Americans, and by doing it secretly she would avoid compromising herself either with the insurgents or the court of London, while at the same time "she would be putting herself in shape to strike decisive blows" when the time was ripe. ${ }^{24}$

'Thus, it was admitted, that secret aid looked forward to possible war. But then, it was argued, a policy of inaction would be no guaranty of peace either, whether England triumphed or the insurgents. For in the one case as in the other the court of London would believe itself warranted in attacking France's colonies. Prudence therefore dictated that the means of waging war with success should be prepared beforehand,

4h., 246-8. 
and one of the most essential of such means was "to make sure" of the Americans. ${ }^{25}$

With the appearance of the Rcflexions began in good earnest the contest for the support of the king, earlier alluded to, between those who wished to see a brilliant diplomatic program adopted and those who, headed by Turgot, urged domestic reform and economy. ${ }^{26}$ At the outset the royal conscience was in the possession of the reformers. Happily for the program of the Foreign Office, in the lively and inventive Beaumarchais, a veritable Cagliostro in the blend he presents of interested calculation and generous enthusiasm, Vergennes had a zealous missionary of his cause and one who, moreover, stood high in the favor of the royal family. On December 7th Beaumarchais handed Vergennes a letter addressed "to the king alone, very important" and headed with the motto summum jus summa injuria. In this extraordinary document the author of Figaro proceeded to attack with vigor the conscientious scruples which he thought stood in the way of the king's adopting the plan of secret aid: "The national policy which preserves

25 $I b ., 249$.

See I avisse, op. cit., 46-51.

s On Beaumarehais' part in the $\Lambda$ merican Revolution see Wharton, I. \$\$ 56-75; John Durand, op. cit., 38-159; Louis de Iomenie, Beaumarchais and his Times (Trans. by H. S. Edwards, N. Y., 1857), Chs. XVII-XX; Blanche E. Hazard, Beaumarchais and the American Rerolution (Boston, 1910). 
states," he argued, "differs in every respect almost entirely from the civil morality which governs individuals." "Salus populi suprema lea." But even if this were not the case good faith would not be due England, "that natural enemy, that jealous rival of your success, that people always systematically unjust to you."

Indeed not even a treaty woukd have justly restrained you on this occasion. For when have the ustrpations and outrages of this people ever had any limit but that of its strength? Has it not always waged war against sou without declaring it? Did it not begin the last one, in a time of peace, by the sudden capture of five hundred of your vessels? Did it not humble you by forcing you to destroy your finest seaport? Has it not recently subjected your merchant vessels to inspection on the northern seas?-a humiliation which would have made Louis XIV rather eat his hands than not atone for it?

Finally, Beaumarchais again invoked general principles. Tranquillity is most safely based on the division of one's enemies, the way to conquer iniquity is to arm it against itself. And if, he concluded, there is anyone who does not agree with me, "heginning with M. de Vergennes," "I close nuy mouth, I cast into the fire Scaliger, Grotius, Puffendorf', Gravina, Montesquieu, every writer on public rights, and admit that the study of a lifetime has been only a waste of effort." Meantime, in August, 1775, the Count de

st Durand, op. ril., 59-i3. 
Guines, acting under instructions from Vergennes, had despatched a certain Bonvouloir to America to travel in a private capacity, to gather impressions, and to insinuate to such influential Americans as he met the admiration felt in France for their noble efforts after liberty, the entire disinterestedness of the French government so far as Canada was concerned, and the welcome which American merchantmen would receive in French harbors. Early in March, 1776, Bonvouloir's first report, which was highly sanguine of American prospects, reached Paris. ${ }^{29}$ Thus confirmed in his idea of the military competence of the Colonies, Vergennes proceeded at once to shape up his plan of secretly aiding them. for discussion by his associates in office. At the same time he still had before him the certainty of 'Turgot's opposition, with the result that there is a marked difference in tone between the $\boldsymbol{M} \dot{e}$ moire de Considérations ${ }^{30}$ and the earlier Réflexions. 'Thus at the outset of the Considerations, in an effort to supersede the language of advocacy with that of scientific detachment, Vergennes concedes ostensibly that whether France and Spain should desire the subjection or the independence of the English colonies was "perhaps problematical," that either event perhaps

\footnotetext{
nharton, I. \$\$38-40. For the report itself, see Doniol, I. 28792, especially 287-8; and for a translation, Durand, 2-16.

${ }^{30}$ Doniol, 1. 273-9; SAISS., No. 1316.
} 
threatened "dangers that it was not within human foresight to provide against." ${ }_{31}$ Also the notion that "Providence had marked out this moment for the humiliation of England by striking her with the madness which is the sure precurser of destruction" is ostentatiously disavowed in the name of both the Bourbon kings." On the other hand, two propositions are offered as axiomatic: first, that the prolongation of the American war would be "highly adrantageous to both France and Spain, inasmuch as it would be calculated to exhaust both the victors and the ranquished"; ${ }^{33}$ and secondly, that whatever the final result of the struggle between England and her Colonies, France could hardly hope for peace, since if England conciliated or subjected the Colonies she would be tempted by the large forces on hand to make an easy conquest of the West Indies, whereas if she lost them, she would be driven thus to indemnify herself. ${ }^{34}$ And from these supposed facts it is held to follow that it was for the interest of both France and Spain, while "dexterously reassuring" England as to their intentions, to "extend the insurgents secret aid both in money and military stores without seeking any return for so doing beyond the political objective

s2 Doniol, I. 273

$\sim \mathrm{Ib} ., 275$.

$I b ., 276$.

s Ib., 274-5. 
of the moment". 'This should be the program for at least the ensuing twelve months. Meantime "the idea of independence, which seems to germinate rather slowly among the Americans," would perhaps have come to maturity. At any rate the two crowns would have had opportunity to perfect their forces. ${ }^{35}$

Adroitly, however, as this argument was framed to anticipate the objections of the controller-general, it did not conceal the essential risk of the program it supported. It is significant, therefore, that the burden of 'Turgot's criticism of the Considerations is a protest against any program likely to precipitate an avoidable war, the expense of which must necessarily aggravate the already serious state of the royal finances. For the rest, striking to the very heart of the foreign secretary's argument, its mercantilist presuppositions, the controller-general predicted that the day of "colonies exclusively riveted to the mother-country" was over, and counselled that that nation would show itself wisest and most deserving of happiness which should first convert its colonists from subjects to allies. Spain, said he, "ought to expect to see herself abandoned by her colonies; it was necessary to make ready for the commercial revolution which the new régime would bring about: by the same sign, there was little need of uneasiness lest England pounce

1b., 277-8. 
upon France's colonies, since there was no advantage involved in longer possessing them." "What difference did it make, then, whether England subjugated her colonies or not? Subjugated, they would occupy her attention by their desire to becone free; freed, their whole commercial system would be altered and England would have no further interest than to appropriate to herself the benefits of the new system.":; As to the likelihood that England was planning to attack France, 'Turgot was frankly sceptical, but, he argued, if that were found to be the case, then France ought to prepare for the danger nearer at home, and especially by strengthening her fleet. Meantime it would be proper to put the Americans in the way of procuring the munitions and even the money they needed by means of trade, but there should be no departure by the govermment itself from neutrality and no act of direct aid. ${ }^{37}$

'Iurgot, however, was fighting what from the first was foreordained a losing battle. In the words of Soulavie, the cause of "Reform, Retrenchment, and Rights to be realized" could not hold its own with a selfish and ambitious court against a program of "Revenge, Glory, and Hu-

se., 281 .

s Jb., 28z-3. 'lurgot also makes the point, later to be cmphasized hy the Spanish government. That "an attack on Fngland would he a signal for the reconciliation of lingland and America and would precipitate the very danger" which the foreign offices policy ostensibly sought to avoid. 
miliation to be retrieved"; and even liberals like LaFayette found the idea of shedding blood for liberty abroad more to their taste than that of shedding feudal immunities at home. There had, indeed, been a period at the end of February and early in March when the Maurepas cabinet had seemed about to succumb to the joint attacks of the friends of Choiseul and Guines. But while the sentiments of the latter nobleman were so excessively pacific that he had just been superseded by the Duke de Noailles at Saint James', ${ }^{38}$ Choiseul was loudly critical of the ministry's apparent failure to appreciate the possibilities of the American revolt; $; 3$ and the total result of the episode had been to solidify the ministry, except for the Liberals 'Turgot and Malesherbes, in support of a more enterprising policy. In their comments on the Considérations, St. Germain, the minister of War, and Sartines, the minister of Marine, did little more than reëcho the arguments of Vergennes, while Maurepas took a line that was frankly belligerent. ${ }^{40}$

3s See Doniol, I. 359-68.

"Stormont to Weymouth, Dec. 6, 1775; Jan. 10 and Feb. 14, 1776: SMSS., 1307, 1313, 1314. For the circumstances attending the recall of Guines from I.ondon, for which, curiously enough, Turgot was primarily responsible, and the intrigue that had for its purpose to hring Choiseul into power, see Last Journal of Hor-

- ace Walpole (Ed. Doran, London, 1859, 2 vols.), II. 9-13.

${ }^{\infty} I b_{s}, 280$, 284-6. The statement as to Maurepas' attitude is based on the assumption, sanctioned by M. Doniol, that the "Reflexions sur la Nécessité de secourir les Américains et de se préparer à la Guerre avec l'Angleterre" was his work. This document 
'The ministerial arguments, moreover, were again supplemented by the ardent advocacy of Beaumarchais, to whose effusion entitled $L a$ Paix ou la Guerre is generally credited Louis' final conversion to the plan of secret aid. ${ }^{41}$ On May 2nd the king at last definitely anthorized the adrance of a million livres to Beaumarchais for the purchase of supplies to be transferred to the Americans. Six weeks later the Spanish court made a similar adrance, and the following August the famous house of Hortale $\approx$ et Cic opened its doors. Within a twelvemonth it had despatched to America eight ship-loads of warlike stores, valued at more than six million lives and drawn in large part from the roval arsenals. ${ }^{42}$ Meantime, on May 12th, 'Turgot had been dismissed, learing Vergennes the directing influence in the ministry.

closes with the following illuminating observation: "Toutes ces considérations réunies pourroient donc porter à conchure même l'offensive comme le seul moyen de rétablir notre marine d'une part et de lautre d'affaiblir celle de l'Angleterre, et comme le seul moyen d'assurer pour longtens la paix du Continent qui n'a jamais été troublée que par leurs intrigues ou leur argent." "The ablest man I knew," wrote Horace Walpole, "was the old Conite de Maurepas. ... Knowing his enmity to this country, I told him . . that it was fortunate for England that he had been so long divested of power." Trevelyan, The Ameriran Revolution, Pt. III. $413 \mathrm{fn}$.

"Durand, op. cit., 74-8.5; I.omenic, op. rit., 267-71.

"See the references in note 97, supra, especially Wharton, I. ș $60 \mathrm{ff}$; also C. .J. Stillé, "Beaumarchais and the I ast Million," Pennsylvania Hagasine of Mistory and Biography, XI, 1-36. 


\section{CHAP'TER IV}

THE PORTUGUESE AND CORSAIR QUESTIONS

For many months secret aid was a mystery closely guarded from even its beneficiaries. 'The decision to render it, none the less, involved certain diplomatic consequences at once. Beaumarchais had not yet begun operations when England lodged a complaint against Americans being allowed to procure powder in the French West Indies and to fly the French flag from their mastheads. ${ }^{1}$ Perceiving the bearing of the question, Vergennes promptly took up an aggressive position. He recalled England's traffic in arms with Corsica when France was subjugating that island. $\mathrm{He}$ asserted entire willingness to abide by the English doctrine that contraband must have a hostile destination, wherefore vessels plying between France and the French islands would not be subject to seizure on the charge of carrying it. He ridiculed the idea that England could pretend a grievance in the fact that the Americans were getting aid from France through the channels of trade: the French markets were open

${ }^{3}$ Garnier to Vergennes, May 6, 1776, Doniol, I. 463. 
to all and those who paid best would have the preference. 'Thus, to use a more modern terminology, Vergennes gave notice of his government's intention to treat the Americans as possessed of "belligerent rights". including the right of an inviolable asylum in nentral ports for their peaceful traders."

But the question of the trading rights of neutrals was from the outset but one ingredient of the diplonatic situation between England and France, and not the most important ingredient at that. Far nore ominous was the stage which the dispute between Spain and Portugal, arising

"Vergennes to Gamier, June 15 and 21 , ib., 466-9. See also Vergenmes to Noailles, Mareh 21, 1757, ib., II. 334: "Nous en [the question of prizes] usons arec les insurgens comme nous ferions avec toute nation amie qui seront en guerre arec l'Angleterre." Other interesting doeuments in the same commetion are Dumas' letter to the Committee of Secret Correspondence. May 14, 1776, Wharton II. 90-2; the "Exposc des Motif's de la Conduite du Roi Très-Chrétien relativement à l'ingleterre," Doniol. III. 8:3-56; and Obsemations on the Instificatory Vemoral of the court of London (sce Appendix 1V), 102-12. That the modern distinction letween "Belligerency" and "Independence" in the rase of communities seeking admission to the Family of Nations foumd no place in the Pnblic Law of the period is shown by the following passige from the pen of llorace Walpole: "An Americall privateer had carried three prizes into Bilboa. The governor had detained them. . . He was ordered hy Gimaldi's letter to restore them, the king of Spain professing an exict neutrality, which was in effect owning our colonies for an independent state," Last Journols, II. si. It it an interesting speculation, to what extent the French alliance with the Lnited States was made necessary by the absence of a distinction which would have enabled France fo aid the Americans without violating England's rights. 
from the latter's aggressions in South America, had now reached. Because of the alliances of these powers with France and England respectively, the outbreak of war between them meant almost inevitably war between England and France as well. ${ }^{3}$ 'The Spanish ambassador at Paris, the Count d'Aranda, who was a bitter enemy of England, had from the first proclaimed this as a welcome development in view of England's growing embarrassment in North America." Vergennes, on the other hand, disliking the obvious ambition of Spain to annex Portugal, both because he regarded such a project as contrary to the precepts of the Système de Conservation and also because he feared for the smooth working of the Family Compact should Spain become the equal of France, had sought to compose the differences of the Iberian states. His efforts at pacification had, however, been followed by fresh aggressions on Portugal's part, instigated, Spain hinted, by the English ;

- "Si la guerre entre l'Espagne et le Portugal devient indispensable, ce que la situation présente des affaires entre les deux puissances ne donne que trop sujet d'appréhender, il est inévitable que la guerre avec l'Angleterre en sera la suite et que la France ne pourra pas se dispenser d'y prendre la part la plus directe." Such are the opening words of the memoir read by Vergennes to the council of ministers held at Marly, July 7, 1776, Doniol, I. 527 .

- $V d$. ib., 35? ff. For an interesting characterization of this unique individual, see Ségur, Mémoirs, I. 390. Cf. Doniol, V. 30.

On the whole matter, see Doniol, I. 75-6, 298-312, 330-7, 525, 532-3. 
and by the begimning of July, Vergemnes had come quite around to Aranda's viewpoint.

A warlike situation now developed rapidly. ${ }^{\circ}$ 'To a council of ministers held at Marly on July 7th Vergennes presented the Spanish-Portuguese matter as offering France the opportunity "to break the power of the single enemy she had cause to fear," provided only French diplomacy was equal to the occasion. First and foremost, the war must be kept from spreading to the Continent, which conld be readily guaranteed by Austria's standing by to prevent Russia from falling upon Sweden. Again, in Holland the ashes of the old Republican party must be fanned to flame once more and Dutch neutrality be secured by appeal to Dutch avarice. Finally, it was essential "to let the Americans know of the present state of affairs and the results which it presaged, and, without assuming engagements with them, yet to make them understand the full advantage which existing circumstances promised had they but the hardihood and patience to await their unfolding."

-Vergennes" English correspondence at this period conlains many sharp criticisms of the treatment French subjects were alleged to be receiving in Newfoundland and Hindoostan. Most of these supposed grievances were long-standing ones. Their revival at this moment is indication of the French government's belligerent intention. See generally the references in note 2 , above.

"Ib., 527-8. Compare Garnier's "Lettre particulière" of May 15, SIISS., No. 868 . 
Four days later Deane, the Continental Congress' first agent to France, who had just arrived at Paris, was admitted by Vergennes to a secret interview. The secretary would not express himself on the subject of American independence, especially as "the United Provinces" had not yet expressed themselves; but he gave assurance that no obstacles would be placed in the way of Americans trading in French ports, whether in munitions or other products. He proposed that Deane should keep the Foreign Office en rapport with all important happenings in America, and strongly advised him to steer clear of Englishmen. ${ }^{8}$ Then on August 13th Garnier wrote from London that the Americans had at last declared their independénce." In a "committee" consisting of the king and cabinet, held on August 31st, Vergennes, casting equivocation aside, proclaimed that, as between the advantages and disadvantages of a war "against England in the present juncture, . . . the former outweigh the latter so unmistakably that no comparison can be made": The Americans had now declared their indepen-

sDeane to the Committee of Secret Correspondence, Wharton, op. cit., II. 119-6. The British government protested against Deane's having been allowed to land in France, a protest at which Vergennes professed to take great unbrage: "Le Roy est le maître chez lui,... il n'a compte à rendre à qui que soit des étrangers qu'il juge a-propos d'admettre dans ses États," Doniol, I. 583 .

Ib., 561 . 
dence. These same Americans it was, their sailors and soldiers, who had made "those rast conquests of which France has in times past so keenly felt the humiliation." 'They were now arailable allies: and, thanks to conmerce, the connection now formed with them conld not fail to be lasting. ${ }^{10}$ Against these arguments no voice was raised, and a week later the memoir embodying them was despatched to Madrid for approval by that court.

Why, then, did not the war come! 'The answer is supplied by the fact that the very day that the response of the Spanish government arrived accepting its ally's program, though with a characteristic stipulation for further delay, ${ }^{11}$ the news came from Garnier of the American defeat at Long Island.' ${ }^{2}$ Vergemmes at once decided that the policy of secret aid still remained the better part of valor, but he was able to eonceal his retreat under the pretext of disapproving of Spain's plan, which still included the conquest of Portugal." "'The king," he wrote, "will alway's regard the aggrandizement of the Spanish monarchy with satisfaction but His Majesty is unable to conceal from the king, his uncle, that the conquest of Portugal would be alarming to all states

"H., 567-7\%, eppecially 570-1; SMSS., No. 897.

"Grimaldi to Aranda, Oct. 8,1776 , Doniol, I. 603-1:s. 'The unain points of the docmuent are summarized on pages 613-1:3.

ib., 615-6.

"Réflexions," ib., 681-s. 
interested in maintaining the balance of power." "If," he continued, "it is a universal maxim, as contended by the Marquis de Grimaldi, that one makes war only for the purpose of gain, yet this maxim ought to be adopted by the two crowns in the existing situation only with the idea in mind that everything is to be gained by breaking down the power of England." Could that be done, then would

France and Spain have achieved an advantage more precious than could be represented by the conquest of a rich province. For once England is unable to keep going the flame of discord among the great sovereigns of Europe, then will the two monarchs no longer be hampered in exercising their better inclinations, which look only to securing to their own subjects and to all Europe the sweet fruits of a sure and durable peace. ${ }^{14}$

A few weeks later we find Vergennes penning the British ambassador the following billet:

Versailles, December 21st, 17\%6. Monsieur: I am indeed touched at the attention shown me by Your Excellency in admitting me to share your joy at the satisfactory news of the success of British arms in Connecticut and New York. I beg Your Excellency to aceept my many thanks at this testimonial of your friendship, and my sincere felicitations upon an event so calculated to contribute to the reëstablishment of peace in that part of the globe. I shall impart the communication made me to the king and now take it upon myself to assure you that His Majesty will always receive with

${ }^{14} / 6 ., 685-7$. 
pleasure news of whaterer may contribute to the satisfaction and glory of the king your master. ${ }^{15}$

Vergennes' policy during the late months of 1776 and the early months of 1777 may be characterized in the poignant phrase of today as one of "watchful waiting." 'The secretary had abandoned none of his fundamental preniises: "The purpose of every offensive war is either to aggrandize one's self or to enfeeble the rival power, whose superiority one fears. . . As everything is relative in the political order, they [the two crowns] will necessarily increase by reason of the enfeeblement of their rival. . . By renouncing every idea of supremacy the English would be free to recognize the independence against which they are armed": and more to like effect. ${ }^{16}$ On

${ }^{36} \mathrm{Ib}$., II. 107, fn. 2. A month earlier than this, Vergennes had told Stormont that it was contrary to the king's intention that his subjects should go to America, SMlSS., No. 905. On Dec. 10, the seeretary ordered Lenoir to arrest all persons giving out that they were intending to go to America, ib., No. 138.5. Vergennes' despatches to Noailles at this period displaty consideranle uneasiness as to British intentions, ib. Nos. 907, 913, and 917. The fact is that Vergennes, relying on American and Spanish assistance, had heen planning an attack upon England for which the French marine was not at all fit. See Doniol, II. 156-70. Hence, the extent of his reaction after the American defeat at Long lsland.

10 Vergennes to Ossmm, Har. 11, 1777, ib., 938-41. See also the document given in Appendix II. Though the work of a "private citizen" it was prepared, Doniol thinks, for the Comncil. I'd. ib., 118. Its speculations as to the effect of the success of the Revolution on France's position in Europe take a wide range. 
the other hand, it is quite apparent that his confidence in the military capacity of the Americans -indeed, in the vitality of their cause-had suffered a great shock from the disaster of Long Island. Of these facts he must again be persuaded before he would consent to risk the dignity of the French crown, and meantime, between American importunity and British suspicion, he must take his way charily.

The clue to the period is furnished by the comparison of two memoirs from the secretary's pen that are dated respectively April 12th and April 26th, 1777. 'The latter, a criticism upon certain propositions of the Spanish government, which still continued in a warlike frame of mind, contained the following homily in favor of peace:

"One knows well enough where war begins, but no one can know where or how it will end. If one could be sure that England would concentrate against us and not extend her efforts to the Continent, the present occasion would be very seductive and it would require a sublime exercise of virtue to repulse it. But the existence of England is a matter of concern from the point of view of the equilibrium of Europe; it is accordingly necessary to anticipate that she will not be left alone. . . The uprising in America has remained up to the present a purely clomestic matter so far as England is concerned; she sees in the insurgents only a people in revolt whom she has a right to recall to their obedience by whatever means lie within her reach and withont other powers having any title to mix up in the affair. To offer to 
intervene would be in some sort to recognize and support the independence which the American provinces have declared, since it is only between equal powers that intervention ordinarily takes place. ${ }^{17}$

'The earlier memoir struck a quite different note. Composed in anticipation of a visit of the emperor to Paris, it urged the necessity of the Austrian connection to France, because, by assuring the peace on the Continent, it pared the way for "taking measures against Fngland, the natural and most inveterate enemy of France, her glory and prosperity."'18

si "Isettre . . communiquée an Roi," etc., ib., gr1 ff., 97?-1 See also passage to like effect in Vergennes to Ossum, Mar. gz, $17 \%, i 3 ., 248$. Mlso, same to same, Apr. 12, where the following work occur: "Si nous pouvions rétablir lopinion du bon état de nos finances, toutes nos possessious servient bien plus en sureté sou, cet abri que sous la protection d'escadres nombreuses qui peuspnt être primées on surpassées," ib., 961,-a sentiment altogether worthy of liurgot!

is /h., t2s; Flisian, Histoire ginérale et raisonnée, etc., VII. 135. see also Vergennes note of February $1 \mathcal{2}$ to Aranda in response to proposition, emanating from the British government looking to a general disarmament by France, Spain, and Great Britain: "Si nous accordons is désarmer uous epargnons sans doute une" grande dépense mais l'oconomie sera plus grande pour l'Angleterre," etc. Doniol, II. 155, 208-9. It was also during this period that the controversy oceurrel between the French and Spanish govermments over the question of sending further reinforcements to Hayti and Santo Domingo, in view of the continued possibility of war over the lortuguese question. Vergennes argued against the iclea on the ground that the climate was tatal to Europeans and on the ground that such a step would tend to alarm (ireat Britain and nuke her less ready to accept France's friendly as- 
Inevitably, it was a period of episodes. It was at this time that LaFayette, eluding the deceptive vigilance of the royal officers, made his way to America, though he would have preferred to lead a filibustering expedition against the English settlements in the East. ${ }^{19}$ It was at this time that the minister of War, St. Germain, induced Steuben to come to America to assist in training the Continental Army. It was also at this time that the Count de Broglie launched his scheme, which had the approval of Deane, for making himself a sort of temporary stadtholder of the United States and commissioned Kalb, Choiseul's former emissary to America, to enlist the interest of Congress.

Writing Kalb from his country-seat at Ruffec, December 11th, Broglie set forth the outlines of his plan as follows:

A military and political leader is wanted, a man fitted to carry the weight of authority in the colonies, to unite its parties, to assign to each his place. The main point of the mission with which you have been entrusted will therefore consist in explaining the advantages, or rather, the absolute necessity of the choice of such a man. The rank accorded the candidate would have to be of the first eminence, such for instance, as that of the Prince of Nassau; but his functions would have to be

surances. As the troops were sent later on (in July: see Doniol, II. 453), we man conclude that the second was the important consideration. See references in Chapter I., supra, note 8.

"Doniol, Il. eh. 2 ; SIISS., No. 756 . 
confined to the amy, ... with perhaps the single exception of the political negotiations with foreign powers; . . the assuranes of the man's return to France at the end of three years will remove every apprehension in regard to the powers to be conferred and will remove eren the semblance of an ambitious design to become governor of the new republic. Of course large pecuniary consideration would have to be claimed for the preparation of the journey and for the journey itself and a liberial salary for the return home. You can give the assurance that such a measure will bring order and economy into the public expense, that it will reimburse the cost a hundred-fold in a single eampaign. You will be equally mindful to dwell upon the effect necessarily produced by such an appointment on its mere announcement in Europe. ${ }^{21}$

I know of no documentary evidence connecting Vergennes with this extraordinary scheme. Yet it seems to me hardly supposable that a great noble like Broglie, who obviously had none of the youthful enthusiasm of LaFayette and who was already more or less at outs with the court on account of his connection with the Secret du Roi, would have risked the king's further displeasure

"Fiedrich Lapp, Life of Kall, pp. 94-5. See also Kallis memoir of Dece. I7, addressed to Deane, which is to be fonnd in the French Archives cles $A$ ffiares etrangeres. Here the additional argument is offered that the step proposed by Broglie would so enlist the interest of the nobility that they would force the king to make an alliance with the Americans. Broglie's own expectations from the scheme are also set torth in greater detail. SMSS., No. 604; Deane Papers. I. 426-31. 
by lending himself to a project of incalculable possibilities without some sort of assurance as to the attitude of his government. Moreover, the plan lent itself rather nicely to the requirements of the American situation as these appeared to the French government at the moment: The American cause was on the verge of collapse for want of competent military leadership; it also lacked prestige in Europe; the king did not dare openly take up the cudgels for so feeble a client; French officers were departing daily for America on their own account; if Broglie failed, it would be as easy to disavow him as to disavow LaFayette, Coudray, or any other; if he succeeded, France would reap the fruits of his success; His Most Christian Majesty has proffered Poland a Conti, why not America a Broglie $?^{21}$

But now a policy of marking time is one that from the nature of things ceases in time to be feasible, for either the event awaited is upon one or it has descended below the horizon of sensible probability. Even by January 1st, 1777, there was in train a series of events that by mid-summer of that year had forced Vergennes finally to choose his position. 'The rendition of secret aid to the Americans through the channels of commerce still continued, but subject to be inter-

${ }^{21}$ See generally C. J. Stillé, "The Comte de Broglie, Proponed Stadtholder of America," Penusylvania Magazine of History and Biogreph!y, XI. 369-405; Doniol, II. Ch. \&; Wharton, I. 391-6. 
rupted at any time by mcasures of the govemment meant to allay British suspicions. The result was discontent on both hands. 'The, perhaps designedly, bungling methods of the agents of secret aid were constantly furnishing Lord Stormont texts for remonstrance, ${ }^{22}$ and meantime American gratitude took on a tinge of resentment. 23

But of far more importance was the fact that Franklin was now in France. Almost from the outset had lranklin's assured front restored the American cause to the footing it had had in popular estimation before the news of Long Island. 'The prestige of his immense reputation-" "more universal than that of Leibnitz or Newton, Frederick or Voltaire"24_had suggested, for the first

z SHSS., Nus. 1306, 1309, 1418, 1427, 1496, 1519, 1531, 1593, etc. In his despatrh to Weymouth of Jan. 7, 1778, Stormont declares that "the very existence of the American army depends ipon the arrival of these suecors," $i b .$, No, 1822.

${ }^{2}$ See, for instance, Iranklin, Deane, and Iee to Vergemnes, Jan. 5, 1776: "We are also instructed to solicit the court of France for an immediate supply of twenty or thirty thousand muskets. . . This application has now hecome the more necessary, as the private purchase made by Mr. Deane of those articles is rendered ineffectual by an order forbidding their exportation": Wharton, 11. 24.5. Also, to like effect, ib., 257. The inadequacy of secret aid to establish any hold on the Americans is recognized ly Vergennes in his despatch to Ossm of Apr. 7, Doniol, I1. 341. ind see ib., genterally, ple. 30.5-12.

" Life and Works of John Adams (Boston, 1856), 1. 660. The fassage is worthy more extencled quotation: "His reputation was more universal than that of I.eibnitz or Newton, Frederick or Voltaire, and his character more beloved and esteemed than any 
time perhaps, that if America was to be made an ally at all, it must be on terms of exact equality. The charm of his unique personality, the interesting phases of which he exploited with faultless facility and with just the touch of charlatanism that the sentimentalism of the age demanded, had served from the moment of his landing at Auray to focus to a blaze of enthusiasm the diverse lines of opinion making among all classes of Frenchmen for the king's espousal of the American cause. $^{25}$

or all of them. Newton. had astonished perhaps forty or fifty men in Europe. . . . But this fame was confined to men of letters. The common people knew little and cared nothing about such a recluse philosopher. Leibnitz's name was more confined still. . . Frederick was hated hy more than half of Europe. . . Voltaire, whose name was more universal . . . was considered as a vain and profligate wit, and not much esteemed or beloved by anybody, though admired by all who knew his works. But Franklin's fame was universal. His name was familiar to government and people, to kings, courtiers, nobility, clergy and philosophers, as well as plebeians, to such a degree that there was scarcely a peasant or a citizen, a valet de chambre, coachman or footman, a lady's chamhermaid or a scullion in a kitchen, who was not familiar with it, and who did not consider him a friend to human kind." Matthew Arnold somewhere comments on the curious fact that America contributed her only world-wide reputation, that of Franklin, while she was still a province.

${ }^{2}$ See generally Edward Everett Hale and Edward Everett Hale, Jr., Franklin in France (Boston, 1886-8, q vols.). "Tout Paris visitait Franklin dans sa maison de Passy. Admiré par les savants et les philosophes qui le comparaient à Socrate et à Newton, il charmait le populaire par sa honhomie et par la simplicité de ses habits bruns et de ses gros sonliers." Lavisse, op. cit., IX.' 104. See also an undated pamphlet by Hilliard d'Auberteuil on Franklin (Penu. Hist'l Soc. Lib.). 
Franklin arrived in Paris December $\mathbf{2} 1 \mathrm{st}$, and two days later he and his associates, Deane and Lee, requested an audience with the French secretary, which was accorded them the 28 th. ${ }^{26}$ 'The suggestion of a formal audience having been eraded by Vergennes, on January 5th, 1777, the commissioners made explicit their expectations of France in a note: "Eight ships of the line completely manned," with which to clear the American coast of British eruisers, and twenty or thirty thousand stand of muskets and bayonets, together with a "large quantity of ammunition and brass field pieces, to be sent under convoy." In return for these favors, Congress offered France and Spain a treaty of amity and commerce and also "to guarantee in the firmest manner to those nations all their possessions in the West Indies, as well as those they shall acquire from the enemy in a war that may be consequential of such assistance as" it requested. ${ }^{27}$ It is hardly surprising that Vergemnes found these demands rather staggering. However, he argued his refusal of them with the utmost suavity and good nature $;^{28}$ and, what is more, followed it up with an advance of 2.50,000 liveres, the first instalment, as he announced, of a loan of two mil-

: Franklin, Deane, and Lee to Comnittee of Secret Correspondence, Jan. 17, 1777, Wharton, II. 248; SHSS., No. 606.

$\therefore$ Franklin, Deane, and Lee to Vergennes, Wharton, II. 245-6.

27 Tote approved by the king, Jan. 9, Doniol, II. 1?0-?. 
lions from the king, who exacted only that the thing be kept secret. ${ }^{29}$

But if Vergennes thought thus to stop the mouths of the Americans, he soon learned his error. Congress' instructions did not at this date permit its envoys to offer France and Spain an alliance,-only treaties of amity and commerce. ${ }^{30}$ On February 2nd, however, with the news before them of the preparation of Burgoyne's expedition in England, the commissioners resolved to break through this limitation and to offer the two crowns a pledge that, if they became involved in war with Great Britain in consequence of making a treaty of amity and commerce with the States, the latter would not conclude a separate peace.

29 Ib., 266 ; Wharton, II. 247,250 fn., 404-5. It must be understood, of course, that until the declaration of the 'Treaty of Amity and Commerce, in Mar., 1778, all of the intercourse of the commissioners and the Foreign Office was guarded from publicity with the greatest care. Certain precautions were, in fact, taken against the Americans themselves, even after they were admitted to the general secret, for it was not impossible, of course, that France might eventually find it convenient to clear her skirts of rebellious associations. "No written proof of the least importance." says Deane, "was ever left in our hands. Even M. Gérard"s letters appointing occasional interviews with us were always without any signature; though five huudred thousand livres were quarterly [in 1777] paid to our banker from the Royal Treasury, not the smallest evidence of the source from whence that subsidy came was permitted to remain in onr power." Deane Papers, IV. 373.

so Journals of the Continental Congress (Ed. W. C. Ford, succeeded by $G$. Hunt, Washington, $1904 \mathrm{ff}$., 25 vols, covering the years $1774-82$, still in progress), $V .768,813$, ff., the Instructions of Sept. $24,1776$. 
'This decision, moreover, was speedily confirmed by new instructions from Congress authorizing "any tenders necessary" to secure the immediate assistance of the Bourbon powers. The result was renewed activity on the part of the commission, and of a much more ambitious sort. ${ }^{31}$ On March 18th Deane sent Vergennes a plan of triple alliance between France, Spain, and the United States looking to an immediate war against England and Portugal. Hostilities were to continue till Spain had conquered Portugal, till the United States had established their independence, and till France and the United States had expelled England from the North American continent and the West Indies; and peace was to be concluded only by the joint consent of the allies.

A few days later Franklin laid a similar scheme before Aranda. ${ }^{32}$ 'The Spaniard was enthusiastic, Vergennes cold. "Considering." the latter inquired of the former, "the condition of lassitude and division in which this people is at present, what security could we have that our diversion would not produce their defection. especially if, as no doubt would be the case, they were offered their independence!" 33 Meantime Lee, having at the instigation of Aranda set out for

"2 Wharton, 11. 257, 260 and footnote; Harrinon of al. to the Commissioners, Dere. 30, 17\%6, ib., 240.

¿2 Doniol, 11. 319-22; Deane Papers, 11. 25-7; SUSS., No. tis9.

Sergenues to Aranda, Apr. 10, Doniol, II. 325. 
Madrid with the idea of approaching the Spanish court directly, had been met at Burgos by Grimaldi and turned back, though with pledges of further monetary aid, some of which were ultimately redeemed. ${ }^{3+4}$ Of this phase of the episode the British ambassador was, however, of course ignorant. Seeing only that a rebel envoy had been denied the hospitality of Spanish soil, he promptly made the fact a theme for obvious comparisons unfavorable to France. ${ }^{35}$

But in less direct ways too did the American commissioners daily contribute to rendering the French government's equivocal position more and more precarious. 'The mere fact that they were in Paris created an ever thickening cloud of speculation as to American prospects and English and French designs. It also brought thither the spies and secret agents both of the British govermment and of the Whig opposition, whose business it was to watch the Americans, the French ministers, and each other. ${ }^{36}$ The quite normal precipitate of such an atmosphere was all sorts of startling rumors, many of which were concerned with an alleged pending agreement between representatives of the British government and the American commissioners, granting the Colonies their independence and providing for the inevi-

\footnotetext{
s4 Ib., 19j-6, 965-6; Wharton, II. 980-3. Cff. ib., 148.

3. Vergennes to Ossum, Apr. 12, Doniol, II. 268 .

sa See Wharton, I. Chs. 21 and 22.
} 
table joint attack upon the French West Indies. ${ }^{3 i}$ Vergennes received these rumors with a measure of scepticism. "We appreciate," he wrote, "how little probable it is that the English would confide so dangerous a secret into the keeping of their enemies as that of their hostile views toward France and Spain, and we are aware how great is the interest of the insurgents to create suspicion." 3. At the same time he recognized that France had not yet done enough for the Colonies "to secure their gratitude," ${ }^{39}$ and he feared the import of the armaments which England was preparing. Indeed, at no time during the Revolution do the hazards of France's equivocal position appear more substantial than at just this period. Yet at no time did Vergennes show himself more bent upon keeping the peace, and that notwithstanding the still belligerent temper of France's ally.

And meantime a fresh element of complexity was introduced into the situation through Franklin's activity in encouraging American privateer's to resort to French harbors. Vergennes had from the first foreseen that difficulties would arise when American "corsairs" began seeking the hospitality of French waters and he had determined to

\footnotetext{
"Doniol, I1. 319, 33.5-8 and fin., and 368-70.

is $16 ., 25 \%$.

: $16 ., 341$.
} 
restrict them to the universally recognized right of asylum, that is the right to take refuge from adverse elements. But this meagre concession, which signified only that the French government did not accept the British view that they were pirates, was little satisfactory to the American vikings. What these individuals demanded was the right to equip, arm, and supply themselves in French ports, to bring their prizes there and sell them, to arm and equip once more and sally forth, -in short, the right to make the French coast a base of operations against English shipping. In vain did Vergennes point out how entirely incompatible such demands were, not only with $\mathrm{His}$ Most Christian Majesty's treaty obligations, but with the Law of Nations itself; for these were a thick-skinned gentry, who well understood that hard words break no bones and with whom measures to be effective had to be drastic. The resultant dilemma personified itself in the bland Franklin and the insistent Stormont. Franklin professed to accept Vergennes' legal principles but was endlessly resourceful in concocting delays to blunt their practical application. Stormont was unremittingly vigilant of results. ${ }^{39}$

"In general, see Hale, Franklin in France, I. ch. 7. Also, the correspondence between the English and Freach government; Doniol. II. 334-5, 478-9 and 504-19; and between Vergennes and the commissioners, $i b ., 520-92$ (translated in Wharton, II. 364-6). See also index to SMSS. under "Conyngham," "Wickes," "Dolphin," "I cexington," "Reprisal." 
By the middle of $J_{u l y}$, the "corsair" issue had become so acute that it was clearly necessary for" the French govermment to cease drifting and take its bearings once more. Meantime, and this was the one material result of the policy of delay, the French marine had reached a plane from which substantial parity with the British marine was within easy reach. In a memoir communicated to the king on July 233rd, Vergennes, contending that the moment had arrived when France must resolve "either to abandon America or to aid her courageously and effectively," pronounced with eloquence and fervor for a close alliance with her. 'The document is worthy of a brief résume."

The primary question, Vergennes declared, was whether France and Spain could afford to see the colonies return either directly or indirectly to British eontrol; and that question turned on the further one, whether it was sound policy to contribute to the strength of an enemy when opportunity offered to enfeeble that enemy. Englind was the natural rival of the House of Bourbon. Mistress again of North Ameriea and its immense resources of all sorts, she would be a menace to the possessions of the two crowns in that part of the world. It followed that the reunion of North America and (ireat Britain, in whatever mamner brought about, could not be indifferent either to the security, the prosperity,

•Doniol, II. 460-69. 
or the glory of the two crowns and that no pains must be spared to prevent it. ${ }^{41}$ Secret aid had been well enough in its day, but it was no longer sufficient to prevent the reconciliation of the colonies and the mother-country, especially since the charge was now made by the English that the policy of France and Spain was to destroy England by means of America and America by means of England. It was necessary, in short, that the assistance rendered the Americans be sufficient to assure their total separation from Great Britain and their gratitude to the House of Bourbon. Open assistance undoubtedly meant war. But war was probably imminent anyway, since if Great Britain failed in the current campaign to reduce the rebels, she would make an accommodation with them and then with their assistance would fall upon France and Spain. ${ }^{42}$ No doubt the magnanimity and religion of the two monarchs made repugnant to them the thought of profiting by the circumstances in which England found herself to give her influence a mortal blow. But in diplomacy self-interest was the major force, and in politics the same maxim held as in war, that it was better to anticipate than to be anticipated. Besides, let their majesties consider whether their flags were respected, their commerce free, whether, in fact, their vessels were

${ }^{41} I b ., 461$.

$\triangle I b, 462-3$. 
not subject from the moment they left home waters, to humiliating visitations, odious seizures, unjust confiscations. ${ }^{43}$ What the situation called for was a close offensive and defensive alliance with the Americans, all parties to which should be bound not to abandon the war without the consent of the others. 'The American commissioners should be informed of the intentions of the two crowns at once; but at any rate decisive steps could not be delayed later than January or February, when the British Parliament would meet to determine the fate of the present ministry. Fortunately, the European situation was in every way favorable to a joint enterprise by the two crowns against England. Spain's difficulty with Portugal was on the way to settlement, and a war on the sea would not spread to the Continent. From such a war, it was possible that the two crowns would not derive every advantage they could hope for, but to succeed in breaking the chain between England and America would forever be an immense advantage. ${ }^{44}$

'The memoir was approved by the king the same day, and three days later was despatched to Ossun, Louis' ambassador at Madril, to be submitted by him to the Spanish crown. ${ }^{45}$ Why then, the question at once arises, was not the

23. 164 . 46.

4 $16 ., 467-9$.

*. Ib., 469 . 
course it recommended promptly entered upon, at least by France? 'The answer is to be found in the altered attitude of Spain. Spain's desire for war during the latter half of $\mathbf{1 7 7 6}$ and the early months of 1777 had rested almost altogether upon the prospect of having Portugal for her quarry. By July 23rd, however, as Vergennes himself noted, the contre-temps between the two Iberian courts was practically at an end. With a new monarch on the Portuguese throne, the warlike Pombal had fallen from power; and meantime the Spaniards under Ceballos had trounced the Portuguese forces along La Plata soundly. ${ }^{46}$ But another factor, too, in bringing about the pending settlement had been Vergennes' constant opposition to the idea of Spain's overrumning her neighbor; and, as was now to transpire, he had therein overshot his mark. For with Portugal out of the calculation, Spain had no wish to fight England, and least of all in behalf of American independence. On the other hand, even Louis' assent to the program of $\mathbf{J u l y}$ 23rd was only a conditional one, the condition being Spanish coöperation. Until, therefore, either Spain could be brought to the support of this program or Louis could be persuaded that it zoas perilous for France longer to wait upon her ally, decisive action was impossible. 


\section{CHAP'TER Y}

\section{FLORIUA BIANCA DEFINES SPAIN'S POSITION}

Notwithstanding a close coincidence of race, religion, and economic interests, and the fact that they were ruled by the same House, the two branches of which were bound together in presumably indissoluble alliance, the French and Spanish peoples of the eighteenth century were strongly disposed to mutual antipathy, not to say antagonism; while between the Spanish and English, particularly of the governing classes, there seems always to have been a considerable measure of reciprocal understanding and sympathy. ${ }^{1}$ So long as Crimaldi, a (renoese by birth, had remained at the head of affairs at Madrid, Vergemnes had not encountered the anti-Gallican prejudices of the court circle of the Escurial. But in February, 1777, Grimaldi had fallen from power and hat been succeeded by a Spaniard of

Sire Francois Rousseau, "l'articipation de l'Espagne à la Guerre d"Amérique," Rever des Qlestions historiques, LXXII. $444 \mathrm{ft}$. Note also Jay's olservation: "They [the Spanish] appear to me to like the linglish, hate the liench, and to have prejudices atgainst us," day to the President of congress, May 26,1780 , ITharton, III. 733 . 
Spaniards, Don José Moniño, the Count de Florida Blanca." 'To be sure, the new minister promptly volunteered the assurance that he would base his policy on the maintenance of the Family Compact, and "the most perfect harmony" between the two crowns ; ${ }^{3}$ but he also soon made it clear that in interpreting the alliance between France and Spain, he would treat the interests of his own country as of quite as much importance as those of France and, furthermore, that he regarded these interests as strictly material. ${ }^{4}$ Accordingly, whereas Grimaldi had accepted Vergennes' contention that Spain as well as France had "much to gain from breaking down British power by effecting the complete and radical separation of the colonies," "Florida Blanca considered "the abasement of England" as without substantial interest to a nation whose Continental rôle was no longer worth restoring. ${ }^{6}$ Nor yet did Vergennes' notion of "a durable peace" to follow upon England's undoing appeal more strongly to him. These were "moral objects," and he frankly characterized them as "quixotic."

However, Vergennes also urged it as an argument for his program that the total separ-

${ }^{2}$ Doniol, 11. 24-7, 197-8.

${ }^{3}$ Ossun to Vergennes, Feb. 24, 1777, ib., 227-8.

"See the correspondence cited in note 59, supra.

- Grimaldi to Aranda, Feb. 4, ib., 192-3.

- Jb., 703. Cff. ib., 567. 
ation of the American provinces from Great Britain would make for the security of French and Spanish colonial possessions in the Western Hemisphere, and he contended further that, inasmuch as Spain's colonial empire in this part of the world was rastly more valuable than the few islands that still remained to France, Spain's interest in bringing about the separation in question was proportionately greater than France's: Again the Spanish minister's views diverrged widely from those of his respondent. For ; while he was ready to admit that British sea-power was more or less of a menace to Spain's holdings in the New World and also that this power was sustained to an important extent by England's mastery of North America, he was not ready to conclude that therefore the independence of England's North American provinces would. so far as Spain was concerned, remove the danger. On the contrary, he held that it would, if due prec autions were not taken, actually increase it. We al e thus brought to a subject that must be of very con trolling interest in the pages following.

One of the earliest adrocates of a FrenchSpanish-American alliance was the Count d'Aranda, the Spanish ambassador at Paris. Unhappily for the Colonies, Aranda was less a representative of his government than a 'Themis-

; $I b ., 161,643-1 ;$ III. 50-1, 140.

'See his memoir on the subject, loc. rit., II. $210-8$. 
tocles in exile,-a former chief-minister whom the existing régime at Madrid found it convenient to devise any plausible expedient to keep remote from the seat of power. So long as Grimaldi was Charles III's chief-minister, Madrid had been quite willing that Paris should make its own arrangements with the rebellious provinces, but even he had not favored Spain's doing more than tio contribute secretly certain funds to the Americar cause, of which he dexterously made France the a lmoner. And after Long Island his attitude becance still more aloof. Writing Aranda as he was about to leave office, he admonished his too enthusiastic subordinate thus:

The $k$ ing our master, who possesses in the Indies domains s;o vast and important, should be very backward in making a formal treaty with provinces which as yet can only be regarded as rebels, an inconvenience that would not exist should the colonies succeed in really throwin $g$ off the yoke and constituting themselves an indepe adent power. The rights of all sovereigns to their respective territories ought to be regarded as sacred, and the example of a rebellion is too dangerous to allow of His Majesty's wishing to assist it openly. ${ }^{9}$

How a little later he met the American Lee and turned him back at the Spanish frontier has already been told.

And if Grimaldi saw cause for alarm on Spain's part in the rebellious example of the Americans,

' $I b ., 192$. 
the Marquis de Castejon, a member of the Spanish royal council, saw it no less in their actual power and their supposed ambitions. "Spain," said Castejon, writing also in February, 1777, "is about to be left alone, face to face with one other power in the whole of North America,-a power which has assumed a national name, which is very formidable on account of the size of its population and the ratio of increase thereof", and which is accustomed to war even before it has begun it. I think that we should be the last eountry in all Europe to recognize amy sovereign and independent state in North America." Such a state would develop more rapidly than a colony, would have its resources immediately at hand. would be uninfluenced by the Balance of Power, and so, careless of the grood will of Europe, would be able to push its own designs with the utmost aggressiveness. Furthermore, even assuming the English colonies in America to have become independent, "the English and American powers would still be of" one nation, one character and one religion, and would so form their treaties and compacts as to obtain the objects they both desire." In such a contingency "the kingdom of" Mexico would be compromised, in fact lost." "10

But indeed the Foreign Office had been forced to meet and allay opinions of this sort even from French sources from the very outset of the Revo-

${ }^{10}$ Sparks MSS., CII. The dale of the document is Fel. 3, 1777. 
lution. Thus in the Réflexions of November, 1775, Gérard had recited: "But, they say, the independence of the English colonies will prepare a revolution in the new world; they will hardly be at peace and assured of their liberty than they will be seized with the spirit of conquest, whence may result the invasion of our colonies and of the rich possessions of the Spanish in South America." In answer to these objections Gérard had urged two considerations: first, that the existing war would fatigue the colonists for a long time to come; and secondly, that if they became independent, the colonists would have a republican form of government and would be united with each other only in a loose confederacy. The dominant spirit of the new community, he had therefore concluded, would be one of trade, industry, and peace: and he had added: "Even supposing that the colonists should encroach upon the Spanish possessions, that is far from proving that this revolution would be prejudicial to France."11

In July, 1777, however, Vergennes had before him the direct task of reassuring Spanish opinion; and it is entirely evident that he had underestimated its difficulty. There are those, he wrote in the memoir of July $23 \mathrm{rd}$, who hold that the time will come when America will be "a formidable

"Doniol, I. 245. See also a passage in the "Considérations," $i b .$, 274. For further arguments against Spain's favoring American independence, forthcoming from English sources, see Wharton, III. $727-31$. 
power even to her benefactors." 'The danger surely was greatly exaggerated. Doubtless America would in time become a considerable nation, but certainly never "a terror to be armed against." For one thing, their constitution stood in the way of such a consummation. For they were held together only by a confederacy of thirteen members, each of which reserved its powers of internal administration. Furthermore, the interests of the several provinees were as diverse as their climate: and particularly striking were the differences between North and South. The South, with its sparse population and with the cultivation of its soil abandoned to negroes, was bound to have commerce for its informing principle. 'The North, it was true, furnished with abundant population liring in frugality, might well breed a spirit of emigration and conquest; but its attention in turn would be occupied with Canada, which to that end should remain in the hands of the English. Also

many rears, not to say ages, must pass, ere the New Englanders have occupied effectively all the lands which still remain for them to cultivate and before therefore they will have a superabundant population which they will want to be rid of ; and ere that time shall have come our vices will have been introduced among them by more intimate intercourse, with the result of having retarded their increase and progress. ${ }^{2}$

$13 \mathrm{lb}, \mathrm{II}, 466$. 
The argument was ingenious but to Florida Blanca, who participated to the fullest extent in the apprehensions that had been voiced by Castejon, it was quite unconvincing. The Spanish minister's program, while the dispute with Portugal was still unsettled, had been that the struggle in America should be kept going till the parties to it were exhausted; meantime France and Spain should increase their forces in the West Indies; then when the moment arrived, they should intervene between England and her rebellious provinces, with the object of filching from the occasion such profits as might be available, perhaps the Floridas for Spain and Canada for France. $^{13}$ And in August, 1777, the Spanish minister was of opinion that the time was not yet at hand for any course of action likely to precipitate war with England, and he was especially averse to the suggestion of an alliance with the Americans: For one thing, the Spanish treasure fleet from Mexico would not arrive until spring, and it would never do to tempt British cupidity with that. For another thing, for the two crowns to declare themselves in behalf of the Colonies would be to furnish England with the best possible argument for coming to an accommodation with them at once. Finally Spain had not yet had an opportunity to build up a sufficient casus belli against the English, to give, that is, her multiplied causes

${ }^{33} \mathrm{Il},, 264,273-4$. 
of complaint that fair appearance of consistency that decency demanded. Mcantime, however, it would be pertinent, with a view to preventing the reconciliation of England and the Colonies, to persuade the latter, through Franklin and Deane, and also through envoys to the Congressional chiefs, that any aceommodation with the mothercountry would be useless which was not guaranteed by France and Spain. "We can assure the deputies at the outset that we would not sanction anything contrary to the liberty and advantage of the Colonies, and that they would be protected in these respects, without saying more for the present." Surely the Americans could not withstand such an inducement. ${ }^{14}$

Obviously balked in his own design by the specious intransigency of the Spaniard, Vergennes, in his despatch to Ossm, of August 22.2nd indicated the willingness of Paris, for the nonce at least, to follow in the wake of Madrid: "We admit, Monsieur, without abbreviation, the hypothesis of the Spanish minister, that before thinking of a rupture we should make sure of the return of our own fishermen and of the fleet from Mexico." Meanwhile, it would be appropriate for the two powers to send secret envoys to America, charged with "brief. indireet hints" as to the advantage

16"Traduction du Mémoire de la comp d'Espague du s aoust 17 if [ xic] servint de reponse à celui de la cour de linance, envoyé le zo .Juillet mêtue année," ib., 490-3. 
that the colonies would gain if, when procuring England's recognition of their independence, they should also obtain "the recognition and guaranty thereof of the European states most interested in sustaining it." 'True, it did appear somewhat improbable that the American deputies in Paris could be brought round to this view. "Ready enough to enter into the closest kind of union if the two crowns would consent to war, they are apparently determined to decline any other sort of diplomatic connection," and "I have had more than one occasion to observe that their art looks not only to interesting us in their cause, but also to compromising us with England." "Still, I will throw out some words to them of a guaranty, and if they refuse to nibble at that bait, I have another idea . . namely, to make them comprehend that it would not be enough to obtain from England a recognition of their independence without taking steps at the same time to establish its permanence," and that the measure best calculated to that end would be treaties of amity and commerce with the powers most interested in seeing them free and prosperous. ${ }^{15}$

But before any action could be taken along this line, opportunity presented itself for Vergennes to press af resh for open war with England. The very day the French secretary penned his despatch to Ossun, an unaccredited agent of the

15 Vergennes to Osiun, Aug. 22, ib., 500-3. 
British government named Forth announced to Maurepas the intention of his govermment to oblige France, uncler pain of war, to return to their British owners all prizes brought into French ports by American vessels. ${ }^{16}$ 'The day following Vergennes presented the king a memoir vigorously protesting against compliance with such a demand. 'To do so, he algued, would be tantamount to stigmatizing the American privateers, and their countrymen as well, as pirates and searobbers: and the result of that would be to arouse resentment in America that would lead at once to reconciliation with England and "a desire for" vengeance that ages perhaps would not diminish." It wonld be in entire accord with his dignity for the king to make some concessions, and policy demanded it on account of the absence of the Spanish treasure fleet. 'The orders against the admission of American privateers and their prizes to French harbors except in "absolutely urgent cases" could be renewed, and such privateers as were already in port conld he sent away, without however the time of their departure being fixed. But more than this could not be conceded. "A great state can undergo losses without suffering in its reputation, but if it subscribes to humiliations, it is undone." As to "an assurance of the possessions of the two crowns in America,"-for apparently Forth had sug16 $I b ., 525-6$. 
gested some such idea,- that would be both minprofitable and useless. "It would tie our hands so that we should be unable to put ourselves in a state of defense" and arm our enemy with a club with which he could always extort some new compliance. ${ }^{17}$

The memoir received the approval both of king and council the same day, and three days later a second despatch was sent Ossun to acquaint him with the new turn of affairs. It was accompanied by a letter in Vergennes' own hand to Florida Blanca, which, recounting that "a new order of things" had most surprisingly intervened since the previous communication, indicated the opinion that it was touch and go as between war and peace, but promised that every precaution which wisdom could suggest would be taken "to avoid if possible that the first blow should be too sensible."1s Four days later, the secretary wrote Noailles, at London, that "the British ministry, despairing of subjugating the Americans ... will seek to direct the passions of the nation against an object more capable of inflaming them, which object can only be France and Spain."

But again the complexion of affairs suddenly altered. Not only did Stormont fail to back up Forth's representations, but what is more to the

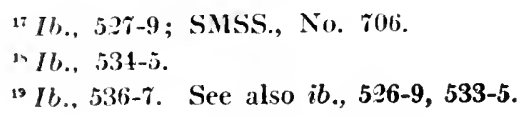


point, the news now came to Paris of Burgoyne's capture of 'Ticonderoga. ${ }^{20}$ As after Long Island Vergennes' anxiety as to the ultimate intentions of the British ministry underwent notable surcease. Florida Blanca was quick to detect the French secretary's vacillation and the opportunity offered for a homily against American wiles. The shaft struck home, for with the advance of Burgoyne through northern New York, further disconcerting intelligence had come from London. His despateh of September 26 th shows the secretary of state in full retreat. though with an arrow or two still in his quiver: The Spanish minister had rightly judged that Forth's mission was not to be taken seriously, but what then was to be expected of a government that lent itself to such pranks in the midst of a civil war! France would give the preference to peace. of that Spain could be assured, and the more so as the moment had passed when by striking at England she could have guaranteed success to the revolution in America. No doubt the attention of France and Spain ought to be directed to winning the confidence of the Americans without entirely forfeiting that of the English but the task would not be an easy one. especially since the English government at least was well aware of what it was for the interest of the two crowns to do, while the Americans on

$$
\because I b ., 53 \pi, 5 \pi \geq \text { fn., } 628 .
$$


the other hand were inconsiderately disposed to look at everything from the point of view of their cwn advantage. ${ }^{21}$

And what precisely was the attitude of the Americans at this juncture? Earlier in the year it had been their tactics to keep before Vergennes the possibility that, unless France promptly espoused their cause, the Colonies, "dispirited by bad success," ${ }^{22}$ might be forced to accept terms from England that would be to the serions disadvantage of France. ${ }^{23}$ But these methods, if they had not actually injured the American case by making the secretary sceptical of the substance and durability of the Revolution, ${ }^{2+}$ had at least netted nothing, and after 'Ticonderoga the commissioners discarded them. Evidence of this fact is to be seen in their letter of September 25th to Vergennes and Aranda, to beg a subsidy of the two crowns or their friendly offices in a negotiation for peace, with a view to saving to America her "liberties with the freedom of commerce:"

${ }^{21} \mathrm{Ib}$., 551-4.

${ }^{2}$ See Carmichael to Vergennes, SuISS., No. 647. The date is illegible save for the year, 1777 , but it was clearly written before the news of Saratoga.

${ }^{23}$ See Wharton, II. 280-3; Deane Papers, I. 434-42, II. 52-6, 66-9; and the memorial prepared early in 1777 hy Franklin, Deane, and the Abbé Niccoli, SMSS., Nos. 149 and 150. 'This document was communicated to I ord Suffolk by the British spy Wentworth and was later quoted by Pownall on the floor of Parliament. See Sulss., No. 182, and Parliementary History, XIX. $930 \mathrm{ff}$.

"See p. 67 supra. 
They [the commissioners, the letter proeeds] can assure Your Excellencies that they have no account of any treaty on foot in Americal for an accommodation, nor do they believe there is any. Nor have any propositions been mate by them to the court of London, nor any the smallest overture received from thence which they have not already communieated; . . and the commissioners are firmly of the opinion that nothing will induce the congress to aceommodate on the terms of an exclusive commere with Britain but the despair of obtaining effectual aid and support from Europe. 25

On October 3rd Vergenmes proposed that France and Spain should each pledge the Colonies three millions liveres on condition that they should enter into no negotiation with Great Britain without the joint approval of the two crowns. Raisons. de finance, he admitted, were apparently opposed on this occasion to raisons de politique. but, he contended, in appearance only, since if Fngland were enfeebled by the loss of America both France and Spain would enjoy peace for many years. ${ }^{26}$ But Florida Blanca was not to be persuaded; and on November 7 th, Vergennes an-

2"S.ISS., No. 1698. See also Lee's "Journal" in R. H. I tee's Life of Arlhur Lee, 1. 354. On November 27, Deame proposed that the commissioners demand "a eategorieal answer" from France. "Dr. Franklin," lee writes, "was of a different opinion: he would not consent to state that we must give up the contest without their interposition, berause the effect of such a derlaration upon them was uncertain. It might be laken as a menace, it might make thern abandon us in despair, or anger. Besides, be diel not think it true." Ite atreed with Framklin.

* Sere 1)oniol, I1. 5(64, 570, 575-s. 
nounced that Louis had determined to give the United States three millions outright, to be paid quarterly. ${ }^{2 \pi}$ Some days later, the Foreign Office instructed one Holker to proceed to America to sound Congress on the question of a FrenchSpanish guaranty along the lines originally suggested by Madrid. 'The instructions were never carried out. On November 30th, the news of Burgoyne's surrender at Saratoga reached Nantes, and M. Holker became the first emissary to Ameriea of a new and decisive policy. ${ }^{28}$

$2 z I b$., 579-80. But word of this decision was apparently not communicated to the conmissioners till after November 30, as no mention is male of it in their report to Congress of that date, Wharton, II. 433-6. And $c f$. ib., 415.

"s $/ b$. 615-6 and notes; SMSS. No. 17ts. Holker late lecame the first French consul at Philadelphia. 


\title{
CIIAP'IER VI
}

\author{
VERGENNES, MAARMIST AND PROPAGANDIST
}

Vergennes' first reaction to the news of Saratoga was that it meant American independence and that the problem presented to France by it was whether she could beat Great Britain ont in according recognition of the fact. "The power," he wrote Montmorin, "that will first recognize the independence of the Americans will be the one that will reap the fruits of this war."' Later he revised this estimate: Absolute independence wottld probably eost the pride of the British monarch too much, but even so, what guaranty was

'Vrrgenues to Montuorin, Dec. 11, Doniol, II. 632; SMSS., Xo. 1769. The works are taken Irom Beaumarchais extremely ala muist letter of the same date to Vergennes: The ministry, he writes, are denonnced in London, the opposition trimmphs, sceret conncili multiply, Ireland prepares to rise. What is the moaning: "It is that of the two nations, Fngland and Fance, the first who recognizes American independence will alone gather from it all the fruits, whilit the independeuce will be certainly fatal to the one that allows its rival to take the lead": SMSS., No. 1768. The letter will also he found in Ioniol, II. 68t. Vergentes' recognition of the decinive character of saratoga was delayed somewhat on aceount of the exultant tone assumed by the British govermment and its ambassador over the news of Howe's capture of philudelphia and $W^{r}$ ashington's defeat at Brandywine: op. cil., 6:0-1, and footnotes. 
there that the Americans, wearied by the war and discouraged by the indifference of $\mathbf{E u}$ rope, would not consent to waive the name if they were given the substance! At any rate, some sort of reconciliation of the mother-country and her rebellious provinces impended and with it the menace of a joint attack by the English and Americans on France and Spain. The succor given the insurgents by the two crowns would furnish from the British point of view a sufficient pretext and the rehabilitation of the French and Spanish navies a sufficient grievance. In such a war, New York would furnish the English a port of embarkment for the French possessions; the American corsairs would enrich themselves by falling upon French and Spanish commerce; the exclusive navigation of the Mississippi would be a powerful lure to the Americans, and in their hands would render the possession of Mexico precarious, because, protected by the British navy, the colonists would have nothing to fear from the vengeance of France or Spain on the American continent. There could not be the least doubt in the world that such a program would be carried through were it not for His Britannic Majesty's squeamishness in the matter of independence. 'Thanks to that, the House of Bourbon had its opportunity. ${ }^{2}$

"Vergennes to Montmorin, Dec. 27, Doniol, II., 665-6; " Mémoire Jû au Roi,” Jan. 7, 1778, ib., 724-5; Vergennes to Montmorin, par l'Epine, Jan. \&, ib., 719-20; SMSS., Nos. 1805, 1824, 1826. 
A question touched upon at the begimning of this volume becomes at this point of renewed interest, that of Vergennes' intention in urging the above argument for his crown's intervention in the Ameriean revolt. Inmediately, of course. his intention is to present the war which this act of intervention will probably bring in its wake as essentially a war of self-defense on France's part, rather than one of aggression, or, to use his own terms, as "a war of necessity" rather than "of choice": and were he thus making, for a policy already determined upon, the usual concession to "the decent opinion of mankind," his words would call for little comment. But in fact he is doing something quite different. He is arguing for the adoption of a proposed policy, and on that aecount it becomes important to inquire with some particularity whether this argument was a sound one, whether it was probable, was sustained by eredible eridence, was consistently adherred to. In the pages immediately following I shall canvass these questions.

Certainly the theory that England, defeated in America, would attack France and Spain had not gained in intrinsic probability in the three years that had elapsed since it was first broached. 'Then the weakness of the French and Spanish fleets had presented British naval aggressiveness an obvious temptation; now, by the statement of Vergennes himself, this weakness had been repaired and Bourbon naval power had become 
matter for alarm on England's part. ${ }^{3}$ 'Then the name of Chatham and his monumental hatred of the House of Bourbon had given viability to the most disturbing speculations; now it was recognized by the French Foreign Office itself, as at least highly probable, that the North ministry would continue as the instrument of His Britannic Majesty's American policies. ${ }^{4}$ 'Then it was plausible to argue that the colonies could yet he drawn off from their pursuit of independence by the ancient lure of an attack on France, and the anticipated assault upon the French Antilles had accordingly been pictured as the first step to reconciliation between England and America. Now it had to be conceded by all that independence was the paramount objective of the Americans, with the result that this hypothetical assault had to be presented as the ontcome of reconciliation. ${ }^{5}$ But in this connection, Vergennes is fur-

\footnotetext{
"See also Vergennes' comments quoted infra on Lord Sandwich's review in Parliament of the British naval situation; note, further, the following words in the Expose des Motifs of the French government (1779): "It is notorious that the armaments of France were in a condition to act offensively long before those of England were prepared," Ammul Register, XXII. 394.

"There was no possibility of Chatham's heing alled to power at this period. Even after Franee had deelared the Treaty of Amity and Commerce with the United States, we find George 111 asserting that "nothing shall bring me to treat personally with lord Chatham"; and again, that "no consideration in life shall make me stoop to Opposition." Jomne, Correspondence of George III, II. 149, 153.
}

"See especially Doniol, II. 664 and 727. 
ther citable for the admission, as we have just observed, that England would not even yet offer the Americans complete independence, that she would insist upon retaining at least a nominal sovereignty over thenl. The question thus emerges whether it was reasonable to suppose that the Americans would consent, in return for less than independence, to join in an assault on the possessions of France and Spain. It was not inprobable that the Colonies, weary of war, would finally content themselves with less than independence, if France did not come to their aid, but it was most unlikely that they would do so with any great alacrity or precipitancy; and just in proportion as the necessity of peace was a motive with them was it unlikely that they would embark upon war in another quarter for a eomparatively winor object, and particularly when, in the pursuit of such object, they would alienate the only powers that had befriended them and whose enmity would leave them henceforth to face alone a still wrathful mother-country."

Nor when I pass in review the evidence offered by Vergennes in support of his alarmist theory,

"Vergennes himself admitted that any arrangement hetwcen kugland and America would "not be the affair of a day," $i b$. 738-9, fu. In his despatch to Montmorin of Dec. 13, the secretary gives it as his own opinion that the commissiomers prefer a coalition with the two crowns to a reconciliation with England: ib., 639. See also the Congressional resolutions of Nov. 22, 1777, and the comminsioners' letter of Dec. 8 to Vergemes, Wharton, 1I. 425-6 and 44-5; also, ll1. 117-9, supre. 
am I better convinced of its substance. First I shall consider some items of a comparatively trustworthy sort that bear on the question of what termis England would be likely to offer America and America be likely to accept. 'Then I shall turn to some items that demand more careful scrutiny.

Vergennes knew from his confidential agents of the visit to Franklin of an Englishman named Hutton, reputed to be a friend of the English king $;^{7}$ and he observed that Franklin remained reticent about the matter. ${ }^{8}$ This circumstance, however, was plausibly explained to him by Chaumont, one of the above-mentioned agents, as due to Franklin's reluctance to prejudice an old acquaintance with the English court, ${ }^{9}$ and we find the secretary himself testifying at this very time to his confidence in Franklin's loyalty and good faith. ${ }^{10}$ Again, he had before him two letters which had been shown him by the American commissioners and which he considered so important that he forwarded copies of them to Madrid. In the first of these, the writer, a citizen of Boston, seems to have advanced the idea that unless France and Spain evinced a disposition to come to the assistance of the colonies, at least in a financial way, Burgoyne's victory could be turned

${ }^{T}$ Doniol, II. 771-2.

s Ib., 718.

"See Note 113, supra.

to Vergennes to Noailles, Dec. 27 , Doniol, II. 65\%, footnote. 
to best account by getting as favorable terms as possible from England." In the other one, which had been sent from London to a secret agent of the commissioners named Bancroft, the anonymous writer foreshadowed the intention of the North ministry to bestow something like autonomy on the colonies for their internal affairs, while retaining control of their external relations, political and commercial. ${ }^{12}$ Lastly, he knew from Deane that an Englishman named Wentworth had visited this commissioner and, suggesting a truce for America, had proposed that the envoys send one of their number either to England or up into the Netherlands, to meet there an Englishman of high rank and negotiate a reconciliation on the basis of a qualified dependency; but he knew also that Deane had met these propositions with a demand for unconditional independence, and that the Englishman had in turn pronounced the latter demand unallowable. ${ }^{1: 3}$

But obviously this evidence is quite insufficient to justify Vergennes' assertion in the memoir of

"Vergennes to Iontmoriu, Dec. 11, ib., 63.34. The coutent of the letter is further revealed by Florida Blanca's comments upon it in his despatch to . I randa of $\mathrm{Dec} .23 \mathrm{rd}$, il.. 6699.

"s.SSS., Non. 1\%87 and 1805; Vergentes to Montmorin, Dec. 27. Doniol, II. 66t-5. For some interesting speculations as to Bancroft's real character, see Wharton, I. 6:1-41.

"Vergennes to Montuorin, Dec. 19, ih., 66l-2; SusS., No. 1796. See alio Beammarchais to Vergennes. Doniol, loc. rit., 65;-6. IVentworth was a spy and stock-jobher in whom George 11 I profered small confidence, Donne, C'orrespondence, II. 109. 
January 7 th, which immediately preceded the king's sanction of an alliance with the United States, that the English government "already . . . displays to them [the American envoys] the certain advantages of a coalition against France and Spain," ${ }^{4}$ and still less, if possible, does it prove that the English government was likely to achieve anything by such tactics. It is true that, in making this assertion, the secretary pleads that "the particulars are too long to detail," though he says the king knows them. ${ }^{15}$ But the fact is that both on this occasion and on earlier ones Vergennes does cite numerous "particulars,"1e which it is fair to conclude are the most cogent ones for his purpose; and while, of course, we do not know what matters Vergennes reported orally to the king, ${ }^{17}$ we do have both the elaborate memoir upon which the royal council based its decision in favor of an American alliance and also the extended correspondence with Madrid at this

"Donjol, I1. 723. 'The statement is repeated in the "Précis of Facts relative to the 'Treaty of Friendship and Commerce," which was read to the Council Mar. 18, SMSS., No. 1904.

15. Ib., 724 .

10 The fact of the matter is that he straightway contradicts the words just quoted, in his confidential letter of the day following to Montmorin, where he writes: "J'espère que ce prince [the king of Spain] nous jugera favorablement lors qu'il aura pézé les raisons exposées dans le mémoire et la dépêche que vous recevrez par (e courier." Doniol, II. 736. For the memoire and despatch referred to, see ib., 717-38.

" "I Roi ... a entendu mon raport particulier, a gardé les piéces, a examiné le pour et le contre": Vergennes to Montmorin, "Privé," Jan. 8: ib., 736; SMSS., No. 1829. 
period; and we may, I submit, reasonably believe that the evidence intended for the eyes of the Spanish king and for the critical scrutiny of the Spanish minister was at least as convincing in character as that which, supplemented by the personal presence and eloquence of the French secretary, persuaded the well-intentioned but stupid Louis of "the moral certainty of peril."

We turn, then, to consider this alditional evidence, if "evidence" it may be called; and first we note the kind of sources from which it issued. So far as is discoverable, Vergennes' informants, with the single exception of the French ambassador at London, were either professional alarmists whose practical interests were already enlisted with the American cause-men like Beaumarchais, Chaumont, and Grand-or the mere anonymous voices of rumor,-as witness his repeated "on dit." From such sources as these it is that the statement finds its way into the secretary's despatches, that the Howes have been instructed to open negotiations with Congress, ${ }^{1: 1}$ that a

" "Ce n’est point linfluenee de ses ministres qui lont déeidé; l'evidence des fixith, la ecrtitude morile du danger et an conviction lont seuls entraine," lor. rit. To the same effect is the letter of Ionis to Charlen, Jan. \&, ib., 713-4.

19 Vergennes to Montmorin, "P.S., Dec. 15, ib., 649: "Ce quoon [.. B.] a recueilli de plus positif est, que des instructions ont été envogés anx froves llowe pour entaner me negociation en Amerique." But compare with this the cautious tone of his despatch to Noailles five days bater: "Des ordres de rócunciliation doirent avoir etce envoyés trís récemment à M. Howe," il., i(k4. For 
special courier has been sent to America, ${ }^{20}$ that Lord George Germaine's secretary is in Paris to treat with the commissioners, ${ }^{21}$ that Franklin's attitude of silence with reference to Hutton is matter for suspicion, ${ }^{22}$ that the first steps have been taken in London toward the formation of a coalition ministry of which Chatham and Shelburne are to be members, ${ }^{23}$ that at Passy "they are negotiating briskly" ${ }^{24}$ and finally, that "one formal proposition is to unite cordially and fall upon us." ${ }^{2 .}$ Ordinarily, it is true, the secretary discloses through what channels he obtained his information; but that fact does not hinder his arguing on the basis of it without allowance for its source, nor yet from simning against the light shed by more reliable sources.

a later rumor that General Howe had arrived at terıns of reconciliation with Washington, see Wharton, II. 483. Thin rumor was of too late clate to find a place in the despatches.

"Doniol, II. 647.

"Vergennes to Montmorin, Dec. 13, "au soir" ib., 645, footnote 2: "D'une autre part le I.ord Germaine ... envoye, dit on [N. B.], ici son secrétaire pour traiter avec les Américains."

2: Same to same, Jan. 8, ib., 718, following Grand's alarmist account of the matter, $i b ., 771$.

${ }^{23}$ Same reference as note 21, supra.

* Same reference as note 22 . The source of this item, which Vergenne, himself says did not influence his decision, was Franklin and Deane's landlord at Passy, who was in Vergennes pay. Sparks MSS., IXXVIII. p. 139.

${ }^{25}$ Doniol, II. 619. The "inconnu" was Wentworth, whose proffers were reported by Deane to Vergennes a day or two later as impossible, since they did not include unconditional independence, supra, p. 127. 
'The person best entitled, both by length of official experience and by first-hand knowledge, to claim something like authority for his conclusions was the Marquis de Noailles, Louis' ambassador at the court of St. James, and indeed Vergennes himself pays striking tribute to the reliability of Noailles' reports. ${ }^{26}$ Yet it is plainly not the policy of the secretary to put forward the ambassador's communications except so far as they can be wrought into the fabric of his own alarmist theory. 'Thus Noailles points out that there can be no binding negotiations between the British executive and the Americans till Parliament shall have repealed certain statutes. Vergennes, without citing Noailles, repeates the observation in his despatches to Montmorin but accompanies it with the conjecture that it will be the policy of the British ministry to solicit overtures from the Americans as a basis for propositions to be laid before Parliament. Again, Noailles always implies that the North ministry will survive. This conclusion, too, Vergennes seems generally to accept; but he pits against it the contention that North and his associates now participate in the Opposition's way of thinking..$^{2 i}$ Again, Noailles assures his government that $\mathrm{N}$ orth will not and

* Same reference as note 21 .

"Unfortmately, what "the Opposition's way of thinking" was is by no means clear. See note helow. As used by vergennes this phrase signified what was for the mout part a figment of his imagination-or calculation. 
camnot offer the Americans their independence. That is quite probable, rejoins the secretary, but the real danger lies in the possibility that the Americans will take less. At this point, however, the divergence between the secretary and the ambassador becomes flat contradiction, for Noailles, like Florida Blanca and Montmorin, is confident throughout that the Americans will never take less. ${ }^{2 s}$

Vergennes is determined, in short, that everything shall be grist to his mill. Unfortunately, there are times when his heroic endeavors to make it such hedge perilously upon dereliction. 'Thus on the authority of the Courier de l'Europe, he erroneously attributes to Lord Sandwich the remark that "the time will come perhaps when complete reparation will be had of France and Spain for their insults," though the version of Sandwich's speech which the scrupulous Noailles had forwarded him contained no such menacing passage. ${ }^{29}$ Again, on no apparent authority at all,

see Noailles to Vergennes, Dec. 12, 23, 26, SMSS., Nos. 1779, 1793, 1803. Cf. Vergennes to Montmorin, Dec. 19 and 27, Jan. 8, 16, and 29, SHSS., Nos. 1786, 1805, 1827, 1838, 1847.

"Vergennes to Montmorin, Dec. 3, Doniol, II. 589. Cf. SMSS., Nos. 1743 and 1772 ; also Parliamentary History, XIX. 479. Even in quoting the above remark attrihuted by the Courier to Lord Sandwich, Vergennes is forced to add the Englishman's admission that "it would be folly to propose war against the House of Bourbon." But he underscores the more alarming sentiment. The Courier de l'Europe was evidently somewhat disposed to sensationalism. See Last Iournals of Horace Walpole, II. 181. 
he attributes to Lord North the idea of a fraternal union with America and a new family compact to confront that of the House of Bourbon, though Noailles' report of the same debate quite correctly credited this idea to Lord Richmond, a Whig advocate of American independence. ${ }^{30}$ Indeed, as late as January 13th, that is nearly a week after the roval council had sanctioned an alliance with the United States, a memoir from the Foreign Office repeats the assertion that England is disposed to sacrifice her supremacy in America for "a sort of family compact, that is to say, a league against the House of Bourbon." This seems to be a distinct reference to the sentiment which, Vergennes must have known, had heen wrongly attributed to Lord North. It is, moreover, the only reference in the document, direct or indirect, to any evidence whatsoever supporting the charge that a coalition between England and America, hostile to France, im-

3. Vergennes to Montmorin, Dec. 13, Doniol, II. 640 and $615 \mathrm{fn}$. ๑. Cf. Noailles to Vergennes, Dec. 12 and 23, SMSs., Nos. $17 \% 2$ and 1793; alio Paliamentary History, XIX. 591 and 609. 'The fact of the matter is that the Parliamentary debates during the period between Burgoyne's surrender and the declaration by France of the Treaty of Amity aud Comnerce were singularly free of bostile Hings at that power. The govermment wanted France's support, the Rockingham Whigs advocated unqualifiod independence for the rolonies, Chatham, opposed to independence, had not yet further indicated his coure. The fact that the only two ditations which Vergennes made at this time of the dehates were the two spmrious anes considered above is signifieant of their general tone toward France. 
pended $!^{3^{\prime \prime a}}$ But even where the secretary's deflections from the most scrupulous methods of propagandism are more venial, they are frequently not less instructive; and it is interesting to observe conjectures which have the form of positive statement in a despatch to Madrid assume, in a despatch of the same date to London, the more modest form of interrogation. ${ }^{31}$

And not less illuminating is the constant habit of the secretary in his despatches of dropping the note of alarm for that of confidence. Examples might be multiplied, but one will suffice, that furnished by his comments upon Lord Sandwich's review in Parliament of the British naval situation:

But why should we look only on the dark side of things? According to Lord Sandwich himself, England has thirty-five ships of the line ready and with some effort could increase the number to forty-two. That then is all she can rely upon to guard the Channel, to observe our fleet at Brest, the Spanish fleets at Cadiz and Ferrol, to protect her establishments and her commerce in the Mediterranean and secure the defense of her islands in America. Even she does not count greatly upon the naval forces which she has in North Ameriea. These consist of such ancient vessels, with such impoverished and dilapidated equipment, that they could lend

soa The memoir is given in Appendix III. It represents an effort to bring together every possible argument for the American alliance.

${ }^{31}$ Cf. SMSS., Nos. 1805 and 1807, hearing date of Dec. 27, 1787. See also note 19 above. 
little assistance to inferior forces. All of which, as you see, Monsieur, is not calculated to discourage the two crowns if they know how to take their time and strike at the proper moment. ${ }^{32}$

How badly these words comport with Vergennes' supposed anxieties for the French Antilles is obvious. But what is equally to the point, the inconsistency thus exemplified is much more than a characteristic of the secretary's argument; it also projects itself into his policy in the most vital way, if we are to regard that as designed primarily for the defense of the Antilles. The only feasible method of either attacking or defending the Antilles was with a fleet; but the United States, though they had ports of embarkment, had no fleet capable of such an enterprise, while Spain, pledged to eome to France's assistance at the first hostile blow, had both a fleet and ports of embarkment that opened directly on the Caribbean. Yet Vergennes deliberately put in jeopardy the alliance with Spain in order to get an alliance with the United States; and in so doing, moreover, made war with England a certainty $!^{33}$

${ }^{32}$ Vergennes to Montmorin, Dec. 27, Doniol, II. 666; SMSS.; No. 1805. See also to same general effect Vergennes to Montmorin, Jan. 30, Doniol, II. 789-90; SMSS., No. 1853. Note, too, the secretary's complacent survey of the defenses of the West Indics, in his "Project de Reponses," to Florida Blanca's questions, which was read to the king Jan. 28, Doniol, II. 78\%.

${ }^{83}$ Of course, if it was assumed that America reconciled with England, would be the one to instigate the attack on the French 
Nor does inconsistency stop short always of contradiction. For the fact of the matter is that Vergennes himself is quotable for the contention that the defense of the French Antilles was not a leading, or even a considerable object with his government. 'Thus, early in the volume I drew attention to a despatch penned shortly after the news of Saratoga in which he wrote: "The interest of Spain is at least tenfold our interest; our islands are little designed to tempt the cupidity of the English; they already have enough of that sort of thing; what they want is treasure, and that is to be got only from the continent." ${ }_{34}$ And the alliance having been consummated, he expressed himself even more to the point:

West Indies and that Englind would not otherwise make such an attaek, then the above argument would fail. But Vergennes suggests America's interest in such an attack in only one passage and that put in the form of an interrogation. Thus, in his despateh of December arth to Montmorin, he writes: "Les Américains nous proposent de conquérir les isles angloises et de leurs $y$ accorder un commerce libre. Si vice versa les Anglois font la mêne proposition, ne sera t'elle pas econtée, sera t’elle rejettée?" Doniol, II. 665. It is true that he represents the Spanish colonies as also presenting certain temptations to the Americans, e.g., the navigation of the Mississippi, lut he also constantly assures Spain that the Americans will be very peaceable neighbors, quite different from the avaricious English. As we have seen repeatedly, it is upon the proverbial eupidity of England and the desire she will have to retrieve her losses that Vergennes bases his whole alarmist argument. As to the Spanish alliance being put in jeopardy, the memoir given in Appendix III proves that the Foreign Office was quite ready to face the possibility, in January, 1778 , that Spain would remain neutral throughout the war. I'd. ib.

Ib., 643. 
It is not, I assure you [he wrote Montmorin, April 3, 1778], without something of pain and effort that the king and those of his ministers who enjoy his closest confidence have brought themselves to adlopt a different course with reference to American affairs than that of the Catholic king and his ministry; but indeed, the interest of Spain herself has had greater weight in our decision than our own interest. The latter is comparatively feeble, if we measure it by our possessions, for these are hardly of a nature to whet the desires of the English, since they have none of the precious metals for which the English are so famished. It is rather toward the Spanish mainland that their eyes are turned, and I demand if England, mistress of the industry and resources of North America, and capable of fructifying these with her own wealth, would not be a neighbor more inconvenient, more formidable than the United States could probably ever become, given over as they are to the inertia which is the very essence of democratic institutions ? 35

Now, of course, it is quite true that these passages both occur in despatches intended for Madrid and designed to persuade that government that its interest lay with France and America, wherefore it may be argued that they are not to be taken too seriously as a revelation of the way of thinking of the French Foreign Office. Let the argument be granted to the fullest extent: what, then, is the implication as to utterances designed primarily for another forum and showing imminent peril to French possessions? Be${ }^{35}$ Ib., 111 . 50-1. 
sides, it does not appear very precisely how, supposing there had been a reasonable degree of likelihood of France having to come to the defense of her possessions, Vergennes' plea in extemuation of her course, addressed as it was to France's ally, was strengthened by disparaging that fact. Palpably, the very contrary is the case.

However, it may be urged from another angle, that the material feature of the passages under consideration is the assertion of France's concern for the safety of Spanish America, and that since this feature constantly reappears both in papers intended for Madrid and those intended for his own court, it is to be taken as expressing a serious objective of his policy. Let this too be granted: the question then confronts us, Why was this so? It will hardly be contended, I suppose, that the French government was moved to any great extent by altruistic considerations, and especially since the course it took was extremely disagreeable to the only possible beneficiary of its altruism. And by the same token, the terms of the Family Compact can scarcely be cited to furnish the required explanation. One explanation, then, and only one, remains: 'The very keen interest that France felt at all times in preventing a British conquest of Spain's holdings in America sprang from considerations connected with the doctrine of the Balance of Power, the idea being that, since Fngland and France were rivals, any accession of new resources to the former would 
put the latter at a correlative disadvantage in the field of rivalry. Yet the moment these considerations are made premises of the discussion, France's vast interest in promoting the separation of Great Britain and North Ameriea looms before us. And which of the two contingencies, this separation or a British conquest of Spanish America, must have appeared the more imminent after Saratoga, and therefore as furnishing the more calculable basis of policy, is hardly a matter for serious doubt.

"The interest of separating the English colomies from the mother-country and of preventing their reunion at any time in any manner zehatsocter is so primary a one that if the two crowns should purchase it at the price of a war a little disadrantageous, yet if they brought this separation about, it would seem that they ought not to regret the war whatever its outcome." Thus wrote Vergennes in December, 1777, while American recognition was still under debate. ${ }^{36}$ And why should France desire this separation? The answer is supplied from another despatch written after the cause of recognition had triumphed, in these words: "That which ought to determine and indeed has determined her [France] to join with America is the great enfecblement of England effected by the subtrac-

${ }^{3} I b .$, II. 644. To the same effect is the memoir given in Appendix III. 
tion of a third of her empire." ${ }^{3}$ And why should France desire the enfeeblement of England! This question is answered in a third despatch, written with reference to the appearance of the Bavarian Succession question, at the moment the American alliance was in the act of consummation. "England is our first enemy, and the others neier had any force or energy except from her."'38 But with these and like passages before us, ${ }^{39}$

37 Vergeines to Montmorin, June $20,1778, i b .$, III. 140.

Vergennes to Noailles, Jan. 17, ib., I1. 745-6 and fn.; SMSS., No. 1839.

Sce Ch. 1, note 21. "Ou est, pourra t'on me dire, la sûreté que cette guerre nous sera heureuse? Je repons d'abord: est elle de choix ou de necessité. Si elle est de la derniere espèce, comme tout en fait la démonstration, il faut donc s'y soummettre avec resignation et courage. Mais supposons quelle soit malheurense, ce qui est bien problématique. Si lindependance de lamirique en est la consequence, si cette independance est absolue; si clle ne produit pas un pacte de fraternite qui reindentifieroit les deux peuples et n'en feroient plus qun, les deux Couronnes n’auront elles pas infiniment gagné d'avoir procuré une separation aussi considerable et diminué d’autant la puissance de leur ennemi inveteré?" Vergennes to Montmorin, Dec. 2\%, Doniol, II. 666. Florida Blanca thus epitomizes the arguments of the French despatches: "la cour de Versailles a pensé de son côté qu'il convenoit à sa gloire, à la bonne politique et aux intérêts les plus 'ssentiels de la monarchie françoise de gagner de vitesse l'activité du ealoinet britannique, et de ne point laisser échaper une occasion aussi favorable (et qui ne se présentera plus jamais) de convertir en avantages immenses pour la maison de Bourbon les mêmes moyens dont les Anglois avoient imaginé pouvoir se servir pour sa ruine; 'ib.. 749. "Lobjet principal des ministres du roi était dassurer lindependance des Etats-Unis et d'enlever ces treize riches provinees à l'Angleterre," Ségur, Mimoires ou Souvenirs ol Anecdotes (1'aris, 1814, 3 vols.), 1. 166. Ségur was a friend and confidant of V'ergennes. 
it becomes evident that the substance of $\mathrm{V}^{\gamma} \mathrm{er}-$ gennes' concern in the period following the news of Saratoga was not, primarily, the security of the French West Indies; that, indeed, the anxieties which he at times professed on this seore, at other times minimized, are not to be regarded too seriously. His real concern, a concern that finds repeated utterance in his despatches and again through Gérard, in the latter's negotiations with Franklin, Deane, and Lee, was of a reconciliation between England and America which, however devoid of belligerent intent toward the House of Bourbon, would yet pave the way for the final restoration of British dominion over the military, industrial, and commercial resources of America, and especially of the last. ${ }^{40}$ In other words, his concern was the obverse of his desire, and, with the evidence that Saratoga afforded of the real dimensions of the Revolution, of his hope, that is to say, the hope of seeing England and America permanently separated. 'The way, however, to make that sure, he argued, was for France to espouse the cause of American independence; for then the Americans would persist till inde-

40 See Doniol, II. 633-4, 638, 640, 655-6 fn., 665-6, 738 fn., and 837; SMSS., Nos. 1831 and 1847. "We must now either snpport the colonies or abandon them. We must form the alliance before England offers independence or we will lose the benefit to be derived from America, and England will still control their commerce." Vergennes to Montmorin, Phillips, op. cit., 73 (citing the Archives des Affaires Étrangères, Espagne, 588, No. 17). 
pendence was in fact won and, when won, would use their liberty of action in ways beneficial to France. But before, of course, he could put this program into effect he had either to persuade his own king and the king of Spain to join in accepting it, or to persuade Louis to take a line of his own. He soon found that the latter alternative was the immediately feasible one, though not so easily feasible; whereas, in so important a matter as this one of intervention, involving the certainty of war, no half-way conversion of the king to the ministerial program would at all suffice. The somewhat abstract argument showing the large but rather intangible advantages to flow from England's loss of North America and its resources, had, therefore, to be supplemented by an argument of a more imperative sort, showing a danger immediate and concrete.

'The notion that French possessions in the West Indies were menaced by a pending English-American coalition played an important part in bringing France into the War of Independence. It was this suggestion, supported by the somber name of Chatham, which first drew Vergennes' infra-Continental gaze to what was taking place on the other side of the Atlantic. It was with the same notion that Vergennes himself was able to counter 'Turgot's argument against secret aid, that it invited war. Iastly, it was with this notion that Vergennes overcame 
Louis' reluctance to part company with his royal uncle for the sake of some rascally American rebels. Yet, when all is said, the theory in question throws little, if any, light on the nature of the principal advantage which the secretary expected that France would derive from intervention. And clearly, his statement at the moment of the royal council's decision in favor of an American alliance, that it was "not the influence of his ministers that decided the king" but "the evidence of facts, the moral certainty of peril," should be taken with a saving allowanee of salt. No doubt Louis reas convinced by the "facts" as they were represented to him; but if the monarch was unable to discern the flimsy texture of hearsay and guess-work beneath the ministerial varnish, the secretary was not so unaware of the quality of his own elaboration, as his constant admissions attest. Nor does "the evidence of facts" from American sources assist his effort thus to bridge the gap between remote possibility and calculable probability. Not a single statement of either Franklin, Deane, or Lee is on record showing either that they ever heard the word "coalition" from any British agent, or that. after Saratoga, they ever hinted such an idea tothe French government, or that they supposed the French government to be alarmed on that score. The argument from silence is not always the most eonvincing, but its concurrence with 


\section{more positive considerations, as in this instance, is at least reassuring. ${ }^{41}$}

${ }^{41}$ The theory of an inpending hostile English-American coalition laving played its part in bringing the king into line for an American alliance was next utilized to exonerate France's conduct to legitimist Europe. The original form of the French government's apology for recognizing the independence of the United States is to be found in the "Précis of Facts relative to the Treaty of Friendship and Commerce," which was read to the Council, March 18, 1778, (SMSS., No. 1904). Several months later a more extended apology was put forth in the form of the Expose des Motifs, etc. (translated in the Annual Register, XXII. $390 \mathrm{ff}$.). In the latter document the following statement occurs: "The French treaty defeated and rendered useless the plan formed at London for the sudden and precarious coalition that was about to be formed with America and it baffled those secret projects adopted by His Britannic Majesty for that purpose." This doeument was answered for the British government by Gibbon the historian in a paper of vast ability, entitled Mémoire justiratif, etc., and written in French. (For translation, see Annul Register, XXII. 397 ff.) Gibhon taxes the French government with having rendered the Colonies secret aid-"the court of Versailles," he says, "concealed the most treacherous conduct under the smoothest professions"; with having revived old quarrels reaching back, some of them, to before the Peace of Utrecht; and with claiming the privileges of a belligerent while professing the character of a neutral. Coming then to the coalition clarge, he writes: "When an adversary is incapable of justifying his violence in the public opinion, or even lis own eyes, by the injuries he pretends to have received, he has recourse to chimerical dangers. . . . Since, then, that the court of Versailles camnot excuse its procedure but in favor of a supposition destitute of truth and likelihood, the king hath a right to call upon that court, in the face of Europe, to produce a proof of an assertion as odious as bold; and to develop those public operations or serret intrigues that ean authorize the suspicions of France that Great Britain, after a long and painful dispute, offered peace to her snbjacts with no other design than to undertake a fresh war 
against a respectable power with which she had preserved alt the appearances of friendship." The anthor of Figaro was now set to answer the historian of the Decline and Fall. I Iis answer, entitled Observations sur les Mimoire justicatif, etc., in its original form practically ignored Gibhon's challenge. The bulk of it consists of an excited review of cases of scizures of lineh vessels by the British on the charge of carrying contraband, and the coalition idea appears in a single paragraph near the end of the docnment. See Ocucres completes (1'aris, 1835), pl. 530-12. The work was unsatisfactory to the Foreign Office, however, and was recast, presumably by Rayneval, Vergennes' secretary. (See Appendix IV and bibliographical data there given.) In the form in which it receiver official sanction the Obstrations rehashes Beaumarchais" review of British seizures, stontly denies Gibbon's charge of secret aid, asserts that the Americans were independent in fact when liance reeognized them, and devotes considerable space to the coalition charge, but without very convincing results. Thus Gibbon's demand for proot is met hy the assertion that naturally the British government was not so imprudent "as to leave direct marks of its darksome manouve" and hy the reputation of the king of France for probity. "It was matural," the docnment continues, "for the British ministry, unable to suhche her Colonies, to seek to be reconciled with them." "In this situation," the query is put, "ought it not to be supposed that, the moment the British ministry perceived the necessity," etc. Finally, it is added: "Moreover, although the king had not had certain proof of the hostile viers of the court of London, it wonld have been sufficient to have had probable grounds to suspect that they existed." ete. In other words, it the fact did not exist, it at least hehooved the French govermment to inmgine that it did. Later passages in the document defend France against the charge of having entered the war for the purpose of crushing lingland: her purpose was only to diminish British pouer, and in this endeavor she represented the interests of Europe. See Appendix IV; also the following note. For the more gencral considerations supporting the conclusions of the above chapter, see chapter $I$, supra. 


\section{NOTE}

Just as the page proof of this book is coming in I receive my April number of the American Historical Review, in which Professor C. H. Van Tyne reasserts the notion that the French govermment's decision to enter into alliance with the United States after Saratoga was determined by the fear that otherwise it would be confronted with a hostile English-American coalition which would pounce on its West Indian holdings. The printer has kindly put space at my disposal for some comments on this article, and I avail myself of the opportunity the more gladly as in doing so I can perhaps make my own position somewhat clearer: 1. To begin with, Professor Van Tyne is in error in stating that this explanation of France's action has heretofore escaped American writers. Pitkin (History, I. 398-400), Otis' Botta (II. 423-39), Perkins (France in the American Revolution, pp. 231-2), and Laura C. Sheldon (France and the American Revolution), passim, all note this argument for the alliance. And see further American State Papers, "Foreign Affairs," I. 569-71. Indeed, so far from the idea in question being at all "elusive," as Professor Van Tyne suggests, it is quite impossible for one perusing the documents to escape it, the only question heing, what weight, when all the evidence is compared, ought to be assigned it in explanation of the alliance. So also, Doniol places the "coalition" argument alongside the "enfeeblement" argument as explanatory of the alliance, without however making any effort to assess the relative value of the two as representative of French motives or to distinguish between the point of view of the Foreign Office and that of the king. See ib., II. 624-5. As to the French writers whom Professor Van Tyne cites as voicing his own view, it may be conjectured that they got the idea from widely circulated Observations described above. But it is to be noted that later writers, like Lavisse and Sorel both of whom have investigated the origins of Bourbon diplomatic policy and both of whom had Doniol available, grive the "coalition" argument

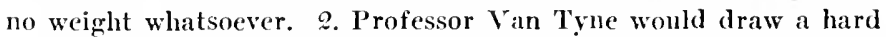
and fast line between the policy of secret aid and the policy of alliance. But as he himself shows, the "coalition" argument was urged no less in befalf of secret aid than in that of the alliance. 
Inded, it is altogether obrious that the reasoning by whicit the Foreign Office supported its policy from start to finish was all of a piece, and that the American rictory at siaratoga-and, consequently. the situation which it produced-acas the consummation, edactly, which secret aid had from the first been intended ta bring about. 3. P'rofessor Van Jyne brings forward what he calls a "key-docoment" to the motives of the Fronch government in entering into alliance with the L'nited States in 17its. I fail to see, however, that this document has any significance whatsocver, save that it may have been the source from which Professor Van Tyne himself first derived his idea of French motives. 'Thus, on the point under discussion, it merely repeats several carlier documents (see previous note) and hrings forward not one iota of additional evidence, except that it apparently endeavors to represent North's conciliatory propositions, which post-dated the alliance, as having been kuown to the fronch government at the time of its decision. Again, it was written more than five years after the events which it narrates. Finally, it was written with the purpose of silencing the very bitter criticism which, after Grasse's defeat in the West Indies, was visited on the ministry's American policy. Vergennes' tactics, it seems clear, are to remind the king of his own responsibility for this policy and so to fasten on his eritics the charge of lise-majesté. See Doniol, V. 186-7 and fu, Reve d'llistoire diplomatique Vil. $528 \mathrm{ff}$; Jobez, La France sous Louis XII (Paris, 1881), II. 492-506. 4. Nor is Professor Van Tyne's citation of one or two other documents in support of his thesis beyond criticism. Thus the Carmichacl memorial cited by him on p. 538 of the Review was written before Saratoga and is in no wise applicable to show the attitude of the American commissioner at the later date. Sec p. 118, supra. Again, the Broglie memoir, cited at P. 537 of the Reriex, makes distinctly against the thesis it is brought forward to support. For while Broglie argues that England must in an endeavor to preserve her rank, try to recoup her losses at the expense of France and Spain, he rejects the idea that the colonies will accept a coalition with her or anything less than independenee. And it may be fairly said that while it is insisted that England will, from the very esperation of her case, fall upon the Antilles, the whole trend of the argument is that she bas alrealy lost her opportunity, 
tog.tiser with her nival superiority. Finally, Broglie opposes an alliance with the Americans, contending that a commercial connection will answer all purposes. See Doniol, II. 674 ff. All of the other material which Professor Van Tyne cites that is relevant to his contention will also be found in Doniol, and is sufficiently discussed in the above chapter. 5. At the close of his article Professor Van Tyne writes thus: It seems "clear that Vergennes did not invent this motive for the alliance-the idea that France was confronted by the dilemma of war with England anyway ... merely ... to get the consent of the king and the other ministers to the plan he wished to pursue. But whether it is his conviction or his device, the idea of this terrible dilemma remains the reason for the decision of the French cabinet." These words avoid the real issue on several accounts: The "terrible dilemma" with which Vergenes confronted the king was not of a war with England simply-for that France, backed as she would have been by Spain, was quite ready (see following chapter) -but of a hostile English-American coalition. Again, the attitude of the cabinet was assured from the first (see pp. 78-9, 85 supra), and it is the conversion of the king alone which Vergennes finds it worth while to explain-in terms meant for the ears of the Spanish court-in his despatch of January 8. See Doniol, II. 736. Finally, since the American alliance was the work of Vergennes, it is the underlying reason for his preference that we really need to know. Does this reason connect itself primarily with the history of French-English rivalry for colonial dominion in the Western Hemisphere, or with the history of French-English rivalry for influence on the Continent of Europe? That is the interesting question. See further, the data in chapter XVI, infra. 


\section{CHAP'TER VII}

TIE TREATY OF ALLIANCE AND OUTBREAK OF WAR

The steps by which the fascinated monarch approached the decision that was ultimately to cost him his crown and his life are visible in the stages by which the Foreign Office and the American commissioners came to terms. On December 6 th the king authorized advances to the Americans looking to a good understanding between the new republic, on the one hand, and France and Spain, on the other,--but nothing more definite. ${ }^{1}$ In the audience that he accorded the commissioners, six days later, in consequence of this authorization, Vergemnes emphasized the fact that the common policy of France and Spain made it impossible for the king to agree to a negotiation without the concurrence of his uncle. 'The Americans in turn indicated their preference for a simple treaty of amity and commerce and renewed an argument they had earlier made, that such an engagement would not involve the two crowns in war. But to this con-

' $I 6$. . 63-6. For further details of this interview and of the envting negotiations, see Lee's "Journal" in R. Il. Lee's Life of A rllur Ler, I. 35i-s9. 
tention Vergennes demurred strongly, urging that if they were to treat at all "it must be in good faith" and on such foundations of justice that the resulting ties "would have all the solidity of human institutions.",

Mid-December came the rumor that Lord Germaine's secretary was in Paris, and Vergennes at once authorized Gérard to go to Passy and "make glitter before his [Deane's] eyes, as consented to in advance, everything necessary to keep the legation in the lap of France." ${ }^{3}$ On December 17th, accordingly, Gérard brought to Passy the news that the king had decided to acknowledge the independence of the United States, to enter into a treaty of amity and commerce with them, and to sustain their independence by all the means at his disposal without exacting any compensation for the risks he took, "since, besides his real good-will to us and our cause, it was manifestly the interest of France that the power of England should be diminished by our separation from it." Of an active alliance, however, Gérard said not a word. On the contrary, according to the united testimony of the three Americans he stated explicitly that the king would "not so much as insist that, if he engaged in a war with England on our account, we should not make a separate peace," the only

${ }^{2}$ Doniol, II. 637-9.

${ }^{3} \mathrm{Ib}, \mathrm{g}, \mathrm{t} \%$. 
condition being "that we, in no peace to be made with England, should give up our independence and return to the obedience of that government.". In other words, while recognition of Ameriean independence had been decided upon, the question of an alliance was still in abevance.

'There now ensued a fortnight's delay while word from Madrid was being awaited. It came the last day of the rear and was unfarorable. A further delay of a week was set against the gout of the aged chief-minister. Meantime, the Americans were pressing for a more indieative sign of the course that France was to take, and the date of the British Parliament's reassembling, January 20th, was drawing nigh. At last, on January 7 th, a royal council, convened at Versailles, declared unanimously for a treaty of amity and commerce with the United States, and a treaty of alliance which should embody the following features: first, it should become operative only upon the outbreak of war between France and Great Britain; secondly, it should have for its end to secure the "absolute and unlimited independence of the United States"; thirdly, it should stipulate a reciprocal guarantee of the possessions of the two powers in North America and the West Indies; fourthly, it should allow the accession of either party to it to a treaty of peace

${ }^{4}$ Wharton, II, 45?-3.

"Doniol, II. i06, footnote, and i6j-j0. 
with the common enemy only upon the consent of the other; lastly, it should provide, in a separate and secret article, for the right of Spain to join the alliance. ${ }^{6}$

The next evening Gérard made a second visit to Passy. Pledging the Americans to secrecy, he began by repeating much of what he had said on the earlier occasion, inveighed strongly against a curtailed independence, especially as to matters of commerce-saying that "clearsighted people had perceived this to be a commercial war from the outset"-and urged that the deputies at once forego every appearance of negotiating with their enemy. Franklin, interrupting, inferred that war would be begun at once by the king upon England, but Gérard answered that such was not the king's plan, that that was out of the question. He then asked what the deputies would consider a sufficient inducement to make them reject all propositions from England which did not include full independence in matters of trade as well as of govermment; also what terms would evoke a like response from the American Congress and people. To the first question the envoys returned answer on the spot: the immediate conclusion of a treaty of commerce and alliance would close their ears to all proposals not providing for the unqualified independence of the United States both political and

${ }^{6} I b . .729-30$. 
commercial. Gérard now announced that he was authorized to say that the king would conclude such an arrangement at once, in the form of two treaties, one a commercial treaty, which should go into effect upon ratification and should be strictly reciprocal, and the other an eventual treaty of alliance. He then referred to the possible conquest of the American continent by the United States, Deane having told him that Franklin was eager for this and indeed found in it the principal reason for an alliance with France. But Gérard indicated that he was uncertain how far His Most Christian Majesty would engage to coöperate in such an enterprise. $\mathrm{He}$ also let them know that he now spoke for France alone and not for Spain, with whom, he implied, they would have to come to terms separately,--an announcement which disappointed Franklin greatly. ${ }^{\top}$

'Three days later the commissioners, through Deane, returned Gérard an answer to his second question. It was a demand for "an immediate engagement" on the part of France "to guarantee the present possessions of the Congress in America, with such others as they may acquire on the

¿Gerard's Narrative, Jan. 9, 1778, Suss., No. 1831. Note that on this occision, as on that of his earlier visit to the commissioners, Gerard's ehief concern was to make sure, not that the Amerieans would not come to terms with lengland hefore making a treaty with France, but that they would not come to terms with her at any time on any other basis than that of complete independence. 
continent during the war, and either to enter into a war with Fingland or furnish Congress with the money" to do so, until "all that the English now possess on the continent shall be conquered" and the English fisheries be secured "to the United States and their allies." From this time forward the principal point of difference between the envoys and the Foreign Office was whether the alliance should go into effect at once or be contingent upon the outbreak of war between France and Great Britain, the desire of the Americans being to see the guaranties stipulated by the treaty effective at once. Though they eventually gave way, they showed themselves, according to Vergennes' unexpectedly pertinacious; and actually, as we shall soon see, their concession was immaterial. ${ }^{9}$ The first drafts of the treaties had been handed the commissioners by Gérard on January 18th; the final drafts were signed February 6th. ${ }^{10}$

${ }^{6}$ The Deane Papers, II. 313-4; SMSS., No. 796.

${ }^{9}$ See Vergennes to Montmorin, Jan. 16 and 30, Doniol, II. 774 and 791 ; S.ISS., Nos. 1838 and 1853; and Lee"s "Journal," in Lee's Lee, I. 388.

${ }^{10}$ The text of the Treaty of Alliance is given in Appendix I. During the final stages of the negotiation, the Foreign Office received two memoirs that may have had some part in inducing the king to take the final plunge. One of these eame from Broglie, who, arguing that England "without colonies and commerce" would be without a marine and without a marine would be "henceforth only a third-rate power" but that she must none the less now concede American independence, concluded from these 
From the negotiations between the Foreign Office and Passy we turn to those that were proceeding synchronously between the Foreign Office and the Pardo: for though the general result of this correspondence has been anticipated, some of the details, too, are of interest. Partially misled perhaps by Aranda's enthusiasm for a French-Spanish-Anerican alliance, which was redoubled by the news of Saratoga, partially misled too, it may be, by his own enthusiasm for

premises that she would, simply in an effort to preserve herself, attempt to appopriate the lench Antilles and portions of Spaninh Imerica. The tace that Broglie was averse to any but a commercial connection with the United States may have given his argument additional weight. Doniol, II. 673-82. Beamuarchais" memoir is in characteristic vein. One of its principal arguments is the assertion that Chatham and shelburne wond probably join the Tory ministry before Fehruary and. Then would follow, it was possible. American independence and a British-American attack on the French West Indies, and Franee would he the linghing-stock of Europe. To meet this situation, the king should at once declare openly that he recognized Ausericiun indeprendence. The docmment thus foreshadows the action taken early in Mareh, in declaring the Treaty of Amity and Commeree, in which connection it should be compared with Vergennes. de-patrh of damary 23rel to Montmorin, written the day following the prenentation of the memoir. The menoir will be found

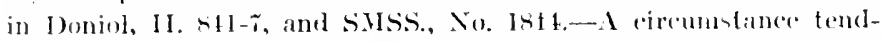
ing to protong the negotiations was the diffienlty that arose between lee and the foreign Office over the XIth and XIth articles of the Treaty of Commerce. It was eventually agreed that Congress should pass upon these articles separately; and Congress

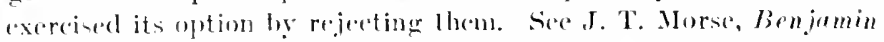
Pronklin (Ameriean Statemen Series), gr ff.; also Wharton, II. 167-tis pussim. 
the enfeeblement of England, but also finding it the better policy to show a confident front on this question that was quite in contrast with his pessimism in the matter of British intentions, Vergennes professed to believe, as long as he could plausibly do so, that His Catholic Majesty could be brought into line quite promptly with whatever policy toward the Americans His Most Christian Majesty should adopt for the security of the House of Bourbon and its possessions.

The aged Ossun, who had long since shown himself quite unable to hold his own with Florida Blanca, had now been superseded at Madrid by the Count de Montmorin, a personal friend of the king and admirer and confidant of Vergennes. Privately the secretary tried to stir the ambition of the young diplomat by a portrayal of the unique opportunity offered by the existing situation. It was an opportunity that could not often recur, especially since, "if we come out of it successfully I hope we shall have quiet for a long time." "11 "Take for your motto," he accordingly exhorted, "and make them adopt it: Ant nunc aut numquam." "Let Spain give her word and the good word and we shall anticipate England." If, however, contrary to all expectations, we should neglect "the most interesting conjecture that heaven could present us, the reproaches of the present generation and of the

"Same to same, "Privé," Dec. 13, SMSS., No. 1775. 
generations to come will accuse us forever of our culpable indifference."12

'To all such pleadings the astute Spaniard turned a heedless ear. He was willing to give abundant money succor to the colonies under "the express condition of an inviolable secrecy"; also to offer them "protection" should they need it. "provided they conducted themselves with loyalty and prudence"; and he admitted that an alert attention ought to be given to the current vicissitudes of the various English parties, especially so far as these might affeet the American question. ${ }^{13}$ For the rest, however, he was as intractable as ever: 'The existing British ministry would never incur the odium of proposing independenee for the Americans and the Americans would now never take less. There was, therefore, no danger of an English-American eoalition unless the British should be spurred to extreme measures by the efforts of France to win over the Americans. For France and Spain to recognize American independenee was quite umnecessary, since their interest attaehed the insurgents to the two crowns anyway. His Catholic Majesty had an inconquerable repugnance to recognizing American independence and the prejudiees of a man of sixty-two were not easily uprooted. 'The

\section{${ }^{12}$ Doniol, II. 614-5.}

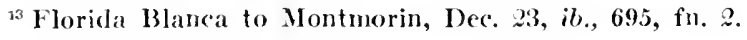


abasement of England was no object to Spain. ${ }^{14}$

Coming to the Pardo one day late in December, Montmorin was informed that a despatch just received from Aranda showed the government at Versailles to be already in negotiation with the Americans. Montmorin had not received word to this effect and believed that the information was false, but he decided not to contradict it at first because he wanted to see what the effect would be if the case really were as Aranda had stated. He soon discovered, for the Spanish minister, in a mounting rage, denounced the folly, inconsiderateness, and precipitaney of France's policy to his heart's content. When the storm had a little abated, the young Frenchman said: "You will be astonished to learn that far from having begun with the Americans, despite the urgency of the case . . . the king awaits . . . the advice of his uncle." For a moment Florida Blanca was taken aback, but soon recovered sufficiently to resume his reproaches: Only the year before Spain had been ready for war and France had backed down. Again, it was France that had left Spain in the lurch in 1762. To treat with the Americans was equivalent to declaring war on Fugland. However, if Spain did enter the war she "would not be the first to ask for peace." "Before asking for it she would sell her last shirt,"

${ }^{13}$ Forida Blanca to Aranda, Dec. 23, ib., 765-70: Mortmorin to Vergennes, sime date, ib., 700 . 
to which Montmorin rejoined pleasantly that he hoped it was the English who would have to sell their shirts. ${ }^{15}$

But if the youmg ambassador thought that he had drawn his eneny's fire against the day when he would have to tell the whole truth about his govermment's poliey he was much mistaken. Louis' decision to ally himself with the Amerieans was communicated to Charles in a note from the roval hand under date of January 8th, ${ }^{16}$ which Montmorin transmitted nineteen days later,- a delay that is to be credited to the fincsise of the French secretary, who, it may be eonjectured, did not wish news of the Pardo's reaction to Versailles' decision until the latter had been put berond recall. 'The Spanish minister's reeeption of the news wals most dramatic. The intensity of his emotion displayed itself in both countenance and gesture. 'To contradict or oppose him was in rain. "He trembled in all his body and had the greatest difficulty in the world in expressing himself." "You think," said he finally, "this moment a most auspicious one for the two crowns; I think it the most fatal for Spain: but it would be the fairest day of my life if the king would let me retire." Next day Montmorin visited the king who, he soon perceived, shared his minister's feelings to the full. Ilis Majesty roiced in solemm tones

\footnotetext{
15 Ib., $696-9$.

"Ib., $\approx 13-4$.
} 
his affection for his nephew and his concern for the peril in which Spain found herself. ${ }^{17}$

Yet in the days following both monarch and minister recovered something of their equanimity in apparent resignation to accomplished fact. 'They were, moreover, counting on the ostensible disposition of France at the moment not to anticipate events further. Vergennes' original program had been to secure Spain's assent to the general principle of an alliance with the United States and then to leave the two powers ample time to make their own terms with one another. ${ }^{18}$ This course he had indeed abandoned when he entered upon negotiations with the Americans, but the 'Treaty of Alliance itself still carefully safeguarded in Spain's interest the margin of time between its signature and the anticipated outbreak of war with Great Britain. ${ }^{19}$ Furthermore, as Florida Blanca analyzed the motives probably governing the British cabinet, this interval was not unlikely to be a considerable one, provided only the initiative were in future left with that body. 'Thus guaranteed, as he thought, the spacious tomorrows so dear to the Spanish heart, His Catholic Majesty's minister began early in February gradually unfolding the expectations of

${ }^{17}$ Montmorin to Vergennes, Jan. 98, ib., 750-9. Sec also Florida Blanca to Aranda, Jan. $27, i b ., 748-50$.

${ }_{18}$ "I Les epoques de l'Espagne seront les notres," Vergemnes to Montmorin, Dec. 11 , $i$., 636. See also $i b ., 637-5$ and 644.

19 Sec the separate and secret article in Appendix 1. 
Spain. "The Spaniards," wrote Montmorin in comment, "are a little like children. 'They can be interested only by presenting shining objects to their gaze." 'The Spaniard on the other hand complained that France's moderation had hopelessly prejudiced his case from the outset. $\mathrm{He}$ did, however, venture to inclicate the restoration of the Floridas and a share in the Newfoundland fisheries as possible objects of ambition to Spain."

But while Florida Blanca was just beginning his bidding in a game which he evidently expected to be a leisurely one, Vergennes was coming to the conclusion that by France and England at least all cards must soon be boarded,---a conchsion to which he was undoubtedly assisted by an interview he had with the British ambassador on January 22nd. Stormont initiated the conversation by taxing the secretary with reports in circulation about Paris of active military preparations going on at eertain French ports. Vergennes, showing embarrassment, disavowed any knowledge of these, whereupon Stormont brought forward the report, which "gains ground every day," of a treaty or eonvention with the rebels or "at least" of Franee's "having accepted some proposals from them." Vergennes now became more embarrassed than the Englishman had ever seen

\footnotetext{
${ }^{20}$ Montmorin to Vergennes, Fth. $2,5,9,16,26$, paraphrased in Doniol, 1I. 795-8.
} 
him, "played with his fingers and remained quite silent," whereupon the relentless Stormont proceeded: "Your Excellency, who was so long a foreign minister . . . certainly knew how to observe the silence as well as the language of those you treated with. You will allow me to follow that example." He then cited an interview of the previous month in which the secretary had met a similar report with a hearty denial, which was no doubt truthful. But on the present occasion, he continued, being unwilling "to stoop to falsehood ... . [you] did not answer a single syllahle." Vergennes now sought retreat behind a distinction between "Lord Stormont" and "the British ambassador": when the former had jocularly questioned "the Count de Vergennes" about the current rumors of an American treaty, "the Count de Vergennes" had been free to respond with candor, but when "the British ambassador" seriously questioned "the secretary of state" on so important a matter, the latter before answering must first obtain the views of his royal master. $^{21}$ Certainly, a rather lame evasion. But what was even more ominous, though "Lord Stormont" continued malignantly to pester "the Count de Vergennes" with unwelcome questions, "the British ambassador" carefully refrained from pressing inquiries "a categorical answer to

\footnotetext{
2t Stormont to Weymouth, Jan. 22, Suss., No. 1816; Vergennes to Noailles, Jan. 24. Doniol, II. 79?-3.
} 
which . . . would probably lead to the most serious consequences." 2

In other words, not only was it evident that the British government took it for granted that a treaty existed between France and Ameriea, but also that it desired to conceal the fact; and, of course, the inference was inevitable that, if concealment was calculated to promote England's plans, it eould not be a good thing for France. ${ }^{23}$ Moreover, the unsatisfactory answer that the Ameriean envoys had, on January 11th, returned to Gérard's second question had, naturally, not been forgotten: while the fact that, if the Treaty of Alliance was eventual as to France it was the same as to Congress also, could not be ignored. Lastly, Vergemnes, recalling no doubt some of his own experiences with legislative bodies on the Continent, began to apprehend the possible ef-

22 Stormont to Weymouth, Jan. 28, SuSS., No. 1851; Vergennes to Montmorin, Jan. 30, ib., No. 1853.

${ }^{23}$ Wentworth, had written, as early as 1)ec. 29 , in the most positive terms, of the decision of France and spain to support Ameriean independence (SMSS., No. 722), but this was obviously mere guesswork on his part; and little eredence seems to have been given by George III to his reports (Donne, II. 109, 121). As late as Jan. 13 George is still confident that the French ministers want peace (ib., 118), but by Feb. 9, he has changed his opinion (ib., 133) and has come to recoguize, in consequence, the need of offering sone measure of coneiliation to America, a thing he had previously opposed, apparently. In a letter of Feb. 23 , Gibhon says that treaties were signed at Paris with the Amcricans on the sth of the month. 
fect of British gold on the loyalty of Congress. ${ }^{24}$

Vergennes' determination to force developments is made clear in his despatch of January $23 \mathrm{rd}$, and again in that of January 30 th. $^{25}$ In the latter he gives renewed assurance of the secrecy of the French government and the American commissioners, but argues that as soon as the treaties reach America the news of them will speedily become public. From this he concludes that it will be necessary for the king to proclaim the 'Treaty of Amity and Commerce by the end of April or the first of May, that is, several weeks before the Mexican fleet will have reached Spain. He accordingly offers Spain the loan of ten vessels of war for her Cadiz squadron and to make sure the safe return of the treasure fleet.

Not only, however, did the Spanish minister sulkily decline the proffered war craft, he also showed himself quite determined not to quicken his pace in negotiation, ${ }^{26}$ thus stressing anew the precarious situation in which France now found herself, with the old love off and the new one not yet securely on. True, the Treaty of Amity and Commerce constituted a pledge of American friendship, but so long as Spain remained aloof, something more than this was wanted; while, on

as Vergennes to Montmorin, repeating a rumor that the English government was sending 500,000 guineas to America to pave the way for a negotiation, Doniol, II. 802, footnote.

i $16 ., 738-9$, footnote, and 789-92; SMSS., Nos. 18.17 and 1853.

$\%$ See note 11 , above. 
the other hand, England, now aware of the existence of a treaty between France and the United States, might at any moment offer the latter their independence, which offer the Americans were still free to accept, and then withdraw from the war. ${ }^{27}$ On February 17th Lord North introduced his plan of conciliation into Parliament. It undoubtedly fell a long way short of according the colonies independence, but there was, of course, the constant possibility of its being further modelled on that idea. ${ }^{28}$ The same day, moreover, a colloquy oeeurred in the House of Commons between Fox and Grenville on the one hand and Lord North on the other which furnished additional evidence that the British ministry was well informed of the subsisting relations between France and Ameriea but preferred to keep the matter hidden for the time being. ${ }^{29}$

${ }^{27}$ See art. I of the Treaty of Alliance.

"Parliamentary IIistory. XIX. 760 ff.; "Instructions to the Earl of carlisle," etc., Apr. 12, 1778, SMSS., No. 410. "Upon the subject of commereial regulations," rmms this document, "the prevaling prineiple has always been to secure a monopoly of American commerce." If these ancient restraints were to be abolished, then certain new ones must be stipnlated in their place. That, lowever, was a matter for l'arliament, hut before it was considered, representatives from the colonies would be adnitted to that hody. Evidently there was no intention of surrendering the old commereial system without a further struggle. See further SMSS., Nos. 359-63 and Parl. Hist., XIX. 379, 577, and 912 .

Parlinmentary History. XIX. 769, 774-5. There was also in- 


\section{On March 7 th Louis approved a declaration of the 'Treaty of Amity and Commerce between France and "the independent States of America,"}

creasing tension between the two governments at this time on aceount of certain of England's naval measures. In Vergennes' despatch of Feh. 2lst occurs the following passage that has an obvious pertinency to recent questions between the United States and certain of the present European belligerents: "Vous lui [Lord Suffolk] ferez sentir... que le droit des gens, les traités et surtout la dignité de la Couronne de France ne sauroient dépendre des circonstances ou peut se trouver la Grande-Bretagne." Doniol, II. 806. Vergennes was evidently now coming around to the view that England meant to attack France first, or to force France to attack her, and then press negotiations in America, ib., 741 ${ }^{-} \mathrm{m}$. 2 , and 803-5. Another circumstance that may have influenced Vergennes in deciding to precipitate developments with Fugland is the belief which he may have formed at this time that $\Lambda$ rthur Lee was acting the spy for the British government. Doniol gives a paper said to he in Vergennes' own hand and endorsed thus: "Extrait d"une letfre de M. Arthur Lee à Md. Shelburne, écrite immédiatement après la signature du traité entre la France et les Etats-Unis de l'Amérique." The passage in question informs Shelburne that the treaty is about to be signed and that England will have to make haste if she is to prevent the alliance of France and the United States. Doniol, III. 169; Wharton, 1. 639. The letter referred to was probably the work of Lee's secretary Thornton, who was undoubtedly a British spy; see data in Wharton, I. 659-61 ( $\$ 207$ ). Again, it may not have been known to Vergennes as early as March 7,1778 . But in this connection, the memoir of Beaumarchais to Vergennes of March 13, 1778, is important. An early paragraph of this document contains the following charge: "Son plan [Ice's plan] ayant toujours été de préférer, entre la France ot l'Ingleterre, la puissance qui le ménerait plus sûrement à la fortune, l'Angleterre, a pour lui des avantages reconnus; il s'en a souvent expliqué dans les soupers libertins," Deane Papers, II. 392. For Beaumarchais' interest in attempting to discredit Iee, see Moncure D. Conway in the Athe- 
which Noailles deposited with the British foreign office six days later. ${ }^{31}$ 'The purpose of the move was threefold; first, to forestall any tampering with Congress by British agents, by making the American public aware that France had recognized American independence; secondly, to

unenm for 1900,1 , 305. lee's loyalty to the Alliance is, in fact, ahove suspicion. See Wharton, 1. 525-50; also I3allagh's Letters "f R. II. Lee, II. 132-42; also l.ee's own "Journal." But the matters above detailed go, of eourse, to explain the distrust henceforth manifested hy Vergemes and his representatives toward lee, and to a less extent toward his relative, $R$. H. lee. See infro.

"1)omiol, 11. S30-6. See also Vergemes to Montmorin, Mar. ij and 10 , for statement of motives, $i b ., 810-2$ and $813-8$. In the latter we find Vergemes reiterating the argmuent that, whatever course Framer took, war was inevitable: "Je pense . . . que quelque parti lue nous prennions, de moderation, de force, ou même de foiblesse, moms ne pouvons plus éviler la guerre. Ce ne seront ni nos engigemens aver l'Amerigue ni les serours que noms pouvons lui averir domés qui nous la procureront; c'est la déronte de Bur-

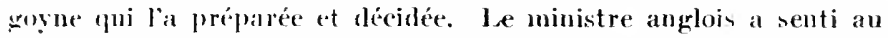
moment même ou ret evénement a éclatté que la contiunation de la guerre pomr sommettre les Américains devenait impossible, mais punr délournér l'animalversion de sa nation de dessus sil manvaise conduite, il nous a destinés deslors à être les objets de la haine nationale et de sa velugeance particulière." However, he rontinues thus: "Je erois bien qu"il ba suspendroit volontiers pour pen de tems jusqu'a ee qu’il ent celui terminer avec les Etats-Unis . . . ; ponrô toutefois que nous comentions à dévorér dams le silence ler afronts multiplies...; mais independan't que re sistème passif et honteux ne peut etre cohi d'une grande puissance, feruerons nous les ytux à lintérêt majenr que nous avous alempecher et prevenir une réenciliation et une coalition entre Pangleterre et l'Amérique qui moiroit res deux nations dans mu uême sistème de paix et de guerre?" Such is the final form of the secretary's apology for his progrant: il., slit. 
hasten the breach between France and England which it was felt the former's recognition of American independence must produce, with a view to making the 'Treaty of Alliance operative; thirdly, to associate America in an act flouting British dignity in a way to anticipate and prevent any proffer by England of independence to the United States. ${ }^{31}$ Fearful that the British government would still endeavor to conceal the insulting intelligence, Noailles was also instructed to drop a hint of it in private conversation. ${ }^{32}$ On March 19th, Stormont left Paris and Noailles London $;^{33}$ and the American commissioners, after being presented at court, dined with Vergemes. ${ }^{34}$ Nine days later, Louis, addressing

${ }^{31}$ In this connection see Chatham's words in the House of Lords, May 30, 1777, Parliamentary History, XIX. 319. Also, compare the attitude of the Rockinghams and that of Chatham when the French-American treaty beame known. The former wished to grant independence immediately, but the latter eontended that national honor forbade. See his last speech, that of $\left.A_{p}\right) r, 6,1778$. So long of course as it was not generally known that the British government knew of the French-American treaty, North was free to offer America what terms he chose. And anyway, even if England should choose to poeket her pride and reeognize American independence, she would plainly have done so because France had forced her to it and the latter power would have America's gratitude. Doniol, II. 815.

32 1 b., 826.

:3 "The French message was deemed so ironic and insulting that at night orders were sent to Lord Stormont to leave France directly without taking leave, and $M$. Noailles was acquainted with that step, that he might retire too," Last Journals of Horace Walpole, 11. 22t. See also Doniol, II. S2s-38.

3t See Gérard to the Commissioners, Mar. 17, Wharton, II. 516. 
two letters to his "Very Dear and Great Friends and Allies," informed Congress, in the one, that he had appointed M. Gérard "to reside near you in quality of our minister plenipotentiary"; and in the other, that he was sending a fleet under the Count d'Estaing "to endeavor to destroy the English forces upon the shores of North America." ${ }^{35}$ The first hostile blows were passed on the evening of June 17th between a French frigate and two English vessels off Ushant. ${ }^{36}$

'Thus step by step did Vergennes lead his halting monarch into war in behalf of American independence. Yet even before the American treaties had been drafted, the Continental peace upon which the success of the design hinged had been brought into jeopardy by the appearance of the question of the Bararian Sucession. ${ }^{37}$ For our purposes it is sufficient to know that upon the death of the Elector Maximilian $\mathbf{J}_{\text {oseph. his suc- }}$ cessor made a treaty in January, 1778, recognizing certain claims of Austria to lower Bavaria and upper Palatinate, and that Frederick II had promptly interfered in the name of other heirs to the lands involved to prevent this treaty's being carried out. France was thus confronted with a difficult alternative. Her traditional policy and

${ }^{35} I 6.521-2$.

${ }^{36}$ Doniol, III. $117-\mathrm{s}$.

"See Vergennes to Noailles, Jan, 17, Doniol, II. $715-6$ and footnotes; SMSS., No. 1839. 
her position as guarantor of the 'Treaty of Westphalia required that she should side with Prussia. But if she did this she ran the imminent risk of throwing Austria into the lap of England once more, which would be the first step, perhaps, in producing a Continental conflagration. Nevertheless, Vergennes decided to follow the line dictated by the Systeme de Conservation and to throw France's weight in with the lesser claimants. Fortunately he was able to count on the peaceful inclinations of Maria Theresa and to draw the czarina to France's side. 'The Treaty of Teschen (May, 1779), which excluded Austria from all but a small district of Bavaria and yet left the 'Treaty of Versailles intact was a great triumph for the secretary's diplomacy and should be regarded as signalizing the restoration of France to something like her former influence in Continental affairs. ${ }^{38}$

And while he was thus saving one situation, Vergennes was creating another, more propitious one. In asserting the right of France to receive American vessels in her ports because of the belligerent character of the provinces in revolt against Great Britain, and of the right of French merchants to send goods to America and to receive them thence, Vergemmes had had occasion to revive and to define with new precision those

${ }^{29}$ Lavisse, Histoire de France, IX. ${ }^{1}$ 98-100, 109-10; Doniol, III. Ch. 3. 
principles of the Law of Nations which the neutral states of Europe had long pitted against the harsher rules that England supported; and in articles XXII-XXVIII, of the Treaty of Amity and Commerce, the opportunity had been seized to give these principles formal and summary statement. Here one will find asserted the principle that "Free ships make free goods"; also, rules restricting the belligerent right of visit and search within narrowest compass: also, a stipulated contraband list confining, for the most part. the prohibitions imposed in the case of such goods, to munitions of war. 'Then on July 28 th, the French goverument issued a Règlement which to a reiteration of the above principles added the principle that a blockale to be binding nust be effective. These principles, neutral states were informed, France voluntarily agreed to observe for the ensuing six months for the benefit of all neutral states, and thereafter, for the benefit of all such states as were prepared to force England to observe the same principles with reference to themselves. The declaration was, in other words. a clever bid for neutral pressure upon Great Britain to force her to surrender her more aggressive rules. But neutral states were wary, and until 1780 the declaration met with only a very qualified suceess. Early in this year, however, the czarina, angered by the seizure of some Russian ressels by the Spanish, issued a declaration of her 
own which followed very closely the lines of its French predecessor; and let it be known, moreover, that she was prepared to back up her principles by force of arms. At Vergennes' instigation both the French and Spanish governments immediately announced their acceptance of this declaration, while the English government held back. The czarina who had hitherto lent her sympathies to England, now transferred them to the Bourbon powers. The result was the First League of Neutrals, which, comprising practically all the neutral powers of Europe, announced its intention of supporting for the benefit of its several members the principles of maritime warfare which had found formulation in the Règlement of July, 1778. To the war which began as a war for American nationality and French prestige was thus imparted the more universal character of a war for the freedom of the seas. ${ }^{39}$

Lavisse, loc. rit., 111-12; Doniol, III. Ch. 12; IV. Ch. 8; Paul Fauchille, La Diplomatie française et la Ligue des Neutres (Paris, 1893). For the Czarina's Declaration and the responses to it of the courts of London, Paris and Madrid, see the Annual Register, for $1780, \mathrm{pp} .347 \mathrm{ff}$. 


\section{CIIAP'TER VIII}

\section{SPANISH MEDIATION AND THE CONVENTION}

OF ARANJUEZ

To have affixed to France's assault upon the British Empire a character that was ultimately to attract the moral support of all Europe and to have preserved the indispensable condition of success for France, peace on the Continent, were notable achievements for Vergennes' diplomacy. Even so, so long as Spain remained a mere onlooker of the struggle, the secretary regarded his war program as lacking a vital element. For one thing. he must show Europe that French and Spanish policy still marched abreast; for another thing, the condition of the royal finances counselled a quick, decisive war. 'To Florida Blanca's frank notification that Spain would never shoulder the risk and expense of war merely for the intangible and highly speculative benefits to flow from the enfeeblement of England and a readjustment of the balance of power he had, as we have seen, lent a heedful ear for some time. Unfortunately, before it had been possible for the Foreign Office "to penetrate Spain's desires," 
the situation had developed which had forced France to break with England; and the result of this step, in turn, was a new obstacle to Spanish coöperation that was quite as formidable as any of those which it reinforced.

The keynote of French-Spanish negotiations throughout the spring and early summer of $\mathbf{1 7 7 8}$ is furnished by the ever recurrent reference in Montmorin's despatches to "the wounded amourpropre" of the Catholic king. Louis had taken action vitally affecting the joint interests of the two crowns not only without awaiting the assent of his uncle, but even without making a plausible show of consulting him. Darkly ruminating this fact Charles concluded that his nephew had come to regard Spain as standing in some sort of viceroyalty to France, from which it followed that Spain's first duty was to herself, to demonstrate her independence and dignity. ${ }^{1}$ Whether Florida

\footnotetext{
${ }^{1}$ Doniol, III. 10-25. Charles had of course been greatly offended to begin with hy the French-American treaty. See $i b$., II. 747-57. Florida Blanca sketched his monarch's character thus: "Caractère mal connu en France, rempli de la plus exacte prohibité, plein dè tendresse pour sa maison, mais défiant, soupçonneux, très attaché à ses opinions; on a offencé son amour-propre, il a crn qu'on le considérait comme un viceroi d'une province de France devant prendre ou quitter les armes suivant les ordres quil recevait; cette idée l'a humilié et dès ce moment il a conçu le projet de prouver qu'il était libre; d'ailleurs, neétant plus jeune, très pieux tonte sa vie, des scruples viennent à présent l'assaillir, le souvenir de ses disgrâces passées le rend timide, tout concourt à lui inspirer le désir déviter la guerre; il fandrait pour le décider lui présenter quelque unccìs hrilliant qui flattât son amour-propre;
} 
Blanca felt the same degree of alarm that Charles professed, lest the younger branch of the House of Bourbon should suddenly find itself in a position of tutelage to the older, may well be doubted, but at any rate his royal master's resentment was too good grist to his mill to be turned aside. Not only did it fend off all danger that an untimely appeal by Louis to the Family Compact would succeed, but it lurnished a further argument for that delay which, the wily Spaniard early discorered, was bound to whet France's appetite for greater aid than the Family Compact stipulated for and which must, therefore, be purchased on Spain's terms."

There was one respect, moreover, and that an important one, in which both monarch and man were in genuine accord in reckoning France's je le connais; quoique dévot l'amour de la gloire le touche et il voudrait illustrer son régne, $i b .$, III. 495. To much the same effect, i, M. Bonrgoing's characterization in his letter to Rayneral of May $25,17 \pi+, i 6 ., 40$.

"See infira. M. Bourgoing's letter, referred to in the above note, contains many acute observations mpon the principal persons and factions then at the Spanish court. Of Florida Blanca he writes: "Discret, dissimulé même, il a le talent rare de bien cacher quand il reut ee qu’il sait, ee quil sent." Comparing him with Aranda, Bourgoing says further: "I.ce deux principaux traits de dissemblance entre ces deux ministres sont que loun est ansis ferme que lantre étoit foible ot facile ì conduire; que l'un se dissimule au point quion ne sait guires qui il hait, qui il aime ni en qui il met sa confiance, au lien que lantre se livroit sans retenue i ser animosités et ne voioit presque rien que par les youx de .... M. de Campo:" $i b ., 49,45$. - For an interesting analysis of Florida 13lanca's policy, see $i b ., 559,576$, and 583. 
precipitancy a substantial grievance to Spain, and that was its tendency to put the question of the American peril out of reach of a satisfactory solution. In March Florida Blanca's views on this subject were still very much "in the vague": The Americans ought first to be allowed to weaken themselves and then left in anarchy akin to that of Germany. ${ }^{3}$ Four months later he was forthcoming with a more definite remedy: "Seeds of division and jealousy" must be sown between the new republic and its former mother-country; to which end the latter must be left Canada and Acadia." The suggestion fell in well with Vergennes' own program, and he at once answered that, while independence "implied the free possession of all parts of the 'Thirteen States," it had not been guaranteed by France for "other English possessions which had not participated in the uprising." ${ }^{\circ}$ And by November, the Spanish court's view of the American question had received yet further clarification from America it-

${ }^{3}$ Montmorin to Vergennes, Mar. 30, 1778, ib., 20 .

"Same to same, Oct. 15 and $19, i b ., 556-9$. In the latter despatch Montmorin makes the good point, that to leave "seeds of dissension" between England and America was to leave the seeds of a fresh war for which, very probably, France and Spain would not be so well prepared as for the present one. He also deprecated the idea that danger could result from the prosperity of the United States. That danger, said he, is "fort eloigné et même incertain."

Vergennes to Montmorin, Oct. 30 and Nov. $2, i b ., 561-2$. 
self." "There is no concealing the fact," wrote Montmorin at this time, "that the interest they feel here in the Americans is not very tender." "Spain regards the United States as destined to become her enemy in no remote future, and consequently, far from allowing them to approach her possessions she would omit no precaution calculated to keep them off, and especially from the banks of the Mississippi." Florida Blanca would "drive both the English and the Americans from the banks of the Mississippi." "He would render forever impossible the accession of the Spanish colonies to the United States, whom he more distrusts than he does the English." "These words, be it noted, do not compromise an appeal from Spain to France, or anything like it. 'They are reported by Montmorin on his own initiative and quite casually. Why, then, the question suggests itself, did Spain not make such an appeal? Plainly, because she recognized that the discussion now touched interests with regard to which

- See eh. XI, infra.

"Montmorin to Vergennes, Nov. 12, ib.. 575-6. To this Velgennes answered: "Il est bien étrange qu'on s'obstine à voir dans les Américains un voisin phus dangereux que ne le seroient les Anglois. Il ne faudroit pour se désabuser quexaminér avec réflexion les constitutions... que les Etats-Unis se sont données. Leur Répuhlique, šils n’en corrigent pas les vices, . . ne sera jamois quu corps foible et suseeptible de hien peu d'activité .... Je vons avone que je n’ai qune foible, confiance dans l'énergie des Etat-Cnis:" ib., 581. Vergemes was apparently somewhat disappointed in the new ally.

\& $16 ., 585$. 
France was already committed; and this being so, Spain must keep a free hand to deal with the American question in accordance with her own interests.

Thus the problem of getting Spain into the war tended to become more and more complicated. At the same time, Vergennes' impatience to bring the thing about became more and more intense. In a memoir addressed to the king on June 20th, he had declared his belief that the temporizing policy of Spain, if persisted in, spelt disaster for both crowns: There could be no doubt, of course, what the choice of His Catholic Majesty would be when it was once made, but delay alone might easily prove fatal to Bourbon hopes. France ought to stand ready, in order to spur her ally to action, to promise aid in recovering Gibraltar, in casting off certain distasteful commercial arrangements that had been foisted on her by England, and in conquering Jamaica, a portion of the Newfoundland fisheries, and the mastery of the Caribbean. ${ }^{9}$ And the Spanish ambassador was not less urgent, though for rather different reasons. From the first a confident prophet of American independence, he was now convinced that the triumph of France and America over England was near at hand. If then Spain wished to be in at the killing, she must

\footnotetext{
" "Réflexions sur la conduite à tenir dans les circonstances présentes relativement à l'Espague," $i b ., 159-63$.
} 
make her election without delay. "It is only a dolt," he declared sententiously, "who armed cap ì pic will consent to stand guard over others comfortably eating their dimners." Spain could not rely indefinitely on any efforts save her own. "When the sowing is late the harvest is usually meagre." "1"

Iranda to Florida Blanca, Dec. 28,1777, April 11, Aug. 4, and Nov. 1, tors, Sparks MSs., Cl\}. Other characteristic expressions from these despaltehes are the following: "There is not much to be read in this despatch, but a great deal to he thought and not hept over." "Spain alome is the party that will be exponed fo danger| unless she takes herd. . . They the Americans| will have no other neighours than Spain,- they elone at hand but we atar off, they increasing in population and fourishing and we the contlary." "let us confess that a like opportunity will not present itself in centuries for Spain to right hernelt in several particulars." "Spain has treasures which she munt redeem. .. This ehance will hardly return while the world shall lant." Writing on $\mathrm{V}$ ay 2,1779 , with reference to the still pending project of mediation, Aranda declared that if it succeeded, he would "weep tears of blood, that Spain should have taken eare of the musiness of others and neglected her own." Florida Blanca expresses the point of view of the Spanish court in his desplateh to Arama of April 19, 178s: "All the considerations that Your Excellency wo wisely sets forlh are less important than that of the king's ceasing to be sovereign and making himself the subject of another in thr great matters of peace and war." In a report on the French navy, of Ang. 4, 1778, Aranda says that ly November it will be, with the naval aid stipulated for by the Family Compact, "in condition to subjugate England without [turther] assistance." "This erowu," he continues, "wants nothing but the disposition; its immense population, its adventurous spirit, its great wealth permit everything." Ile predicts the suecess of Frances enterprise and resulting "tranquility for many years." Evidently, he had focemes thoronghly indoctrinated in Vergemnes" viewpoint. 
But was Spanish aid really worth waiting for? Would it-considering the sulky humor of Charles and the palpable self-seeking of his minister-be worth the price that would have to be paid for it? Young Montmorin was sceptical. "The moderation affected to-day," he wrote, "will to-morrow make way for an ambition that will cause more embarrassment than Spainish assistance will pay for." 11 Vergennes, however, for the reasons already suggested, gave the warning less weight than, in the light of subsequent events, it may seem to have deserved. His answer was that assurance could not be made too sure, that another campaign must see the two nations acting together, if it was humanly possible to bring the thing about. ${ }^{12}$

The road by which Spain finally took her leisurely way into the war was the edifying one of mediation. There were several reasons why it seemed good to Florida Blanca to dress his monarch up as the champion of peace and capable in

Further eorrespondence between the two men is taken by Sparks from D. Antonia Ferrer del Rio, Itistoria del Reinado de Carlos III en España, III. pt. V., ch. I., Pp. 956-67. Aranda in a postseript had quoted Maurepas as saying that evidently "Spain loped, by her mediation, to pick something from the eracks." This makes Florida Blancil extremely angry. "It is a malicious invention," he says, but continues that if "England is hard picking for us, we shall not be less so for those gentlemen." Sparks MSS., XCIII.

11 lieport of June 29 , Doniol, III. 473.

${ }^{12}$ Sce $i b ., 481-5,486,526-32$, etc. 
its interest of dispensing an even justice between France and her ally on the one hand and Great Britain on the other. For one thing, the proposal gave His Catholic Majesty that independent rôle which his affronted dignity demanded. Again, it furnished a new reason for delay. Lastly, in the form it finally assumed, it promised Spain an opportunity to curtail American independence.

The great difficulty was to get the idea launched under proper auspices. For Franee, whose act had precipitated the war, to solicit Spain's good offices at the outset would have been ridiculous; while England on the other hand, entirely apart from her natural distrust of the connection between France and Spain, was of no mind to accept peace on any terms that did not leave her free to deal with her rebellious colonies as she saw fit. A round-about hint from Florida Blanca in April that His Catholic Majesty's services were available to England and France, which was accompanied by some absurd by-play designed to conceal the mamner of its origination, was met with a blunt snub from London. Florida Blanca vented his chagrin on the British ambassador, and for the moment it looked to Montmorin as though Spain might enter the war without more ado. ${ }^{13}$ But so incon-

1: For these and other details with reference to this abortive effort at mediation, see ib., 56-50, passim. 
tinent abandonment of the cause of his affronted dignity was hardly to be expected of the quixotic Charles. Four months later, howerer, His Catholic Majesty had begun to relent somewhat, and the English government, alert to the fact and eager to keep Spain out of the autumn campaign, did, in September, convey a very definite intimation to the Spanish ambassador at London that His Britannic Majesty hoped to see "the war ended by the mediation of Spain" and "had no doubt that she would be able to save the honor of Great Britain without lessening that of France."14 From the point of view of the necessity of placating Charles this event may well be regarded, as M. Doniol indicates, as decisive. On September 28th, Florida Blanca sent a note to Almodovar stating the moral obligation that Spain would be under if England did not submit propositions along with the king of France, and ten days later Vergennes also, conformably with a hint from Montmorin, wrote the Spanish ambassador formally accepting Spanish intervention. ${ }^{15}$ Charles' gratification expressed itself in a variety of attentions to the French ambassador, while Florida Blanca, though ostensibly sceptical of peace, professed to be not less satisfied on that account. He now predicted to Montmorin that the following spring would find Spain in arms alongside her ally. ${ }^{16}$

"Ib., 513. See also ib., 497-9.

"s $/$ b., 315 and footnotes.

$16 ., 516$. 
From this point on, though Spanish policy contimues as devious as ever, the comse of events becomes comparatively straightforward. 'The British answer to the Spanish note of September 28th was delayed some six weeks, and when it arrived, it laid down the impossible condition that mediation must be preceded by the withdrawal of the French fleet from American waters and the cessation of French aid to the Americans. ${ }^{17}$ 'The obvious incompatibility of these conditions with those that had already been laid down by France ought. it would seem, have at last given the mediation project the bare bodkin. ${ }^{1 s}$ But the obstinacy of the Spanish monarch, who now had the scent of a great rôle in his nostrils, and the subtlety of his minister, who still saw profit in delay, were equal to the oceasion. On November 2oth Charles himself addressed Louis a note aceompanied by a "eonfidential declaration" in which, while France's obligation to secure independence for the United States was fully recognized, it was pointed out that the demand for

17 $16 ., 524$.

18 The French conditions are laitl down in the "Articles at proposer pour la Paix" of Oct. 17, ib., 551-4. 'The first paragraph reads: "I.e roi d"Angletere avoutra l'indépendence absolue des 13 Etats-Cnis de l'Amérique septentrionale pour le politique, le civil, et le commerce et les reconnoitra pour Ftats souverains et parfaitement lihres. S. M. B. s'engagera de retirer inmédiatement toutes les forees de terre et de mer qu'elle tient dans aucune partie des dits Ftats-lnis et de leurs renettre toutes les places, territoires, to isles an dépendans." 
a direct and formal recognition of it would be a serious offense to British pride. Why then, it was argued, should not the procedure that had been taken in the case of the Low Countries be followed again? In that case France, supporting the liberty and independence of Holland against Spain herself, had been content with obtaining, in the first place, a long truce in favor of her protégé, and then, when Holland had wished to make a definitive treaty with Spain, had merely stipulated that this should not be ratified without her consent. Peace, the Spanish court further urged, was necessary to America herself, wherefore there was always the danger that England might seduce the Inited States into accepting a separate treaty,- - a poignant argument at the moment, as we shall presently appreciate. The conclusion was inevitable that some sacrifice in form was advisable to secure peace at once, though no sacrifice of real obligation. ${ }^{19}$

It is perhaps hardly necessary to point out how entirely this proposal of a truce for a term of years for the Americans in lieu of a permanent peace met Florida Blanca's problem of neutralizing American independence as far as possible. Such an arrangement would abound in opportunities for "sowing seeds of discord" between the English and Americans and, by the same

${ }^{19} I b ., 622-3$. 
token, in opportunities for making the latter feel the necessity of a guaranty of their independence from the Bourbon erowns. And such a guaranty need not, of course, be accorded gratuitously. It might well be made to bring a substantial price in terms of American territory along the Mississippi.

But though fully awake to the possible advantages to Spain of peace in America on such a basis, the Spaniard was not over-credulous of its ever coming about, nor blind to the necessity of keeping the door hospitably ajar to the other alternative. The royal communication and memoir were accompanied to Paris by a characteristic product of the minister's own pen, addressed to Vergennes: His Catholic Majesty was still genuinely hopeful of peace, but at the same time he was well aware of the possibility that negotiations might fail. $\mathrm{He}$ accordingly still contimued his preparations "with the greatest activity and trusted that his nephew was doing the same." Indeed, the king was "of the opinion that without the greatest dissimulation up to the very moment of striking no advantage could be got of England." Meantime, it became pertinent to inquire what "advantages spain might obtain, and how and in what terms France might bring herself not to listen to any proposition withont assuring them to" her. ${ }^{20}$

5" Ib, 619-21. The last sentence quoted above is underscored in the transation of the document by Vergennes. 
Before, however, Vergennes could deal with this most significant inquiry, he had to settle the more exigent question posed by the royal communication, whether France could, harmoniously with her engagements with the United States, accept for them a truce in substitution for a permanent peace. His first opinion was plainly adverse. "The Peace of Vervins," he wrote Montmorin, December 1st, "was unavailable as a precedent in the case of the Americans," for the situation of France and her engagements with the United State were of "quite a different character to those which Henry IV and his predecessors had contracted with the Dutch." ${ }^{21}$ But as it happened, Franklin's English friend Hartley was at this very moment urging much the same idea from the British point of view. When accordingly Franklin, making a confidant of Vergennes, showed the latter Hartley's letter, it was not difficult to elicit from the American the sentiment that

provided France and Spain were ready to accord the United States their good-will and protection, independence, whether recognized as a matter of right or only as one of fact, would be a very good thing for them, in that it would secure them, along with the sweets of peace, or of a truce, the time and opportunity to perfect their political arrangements and internal order. ${ }^{22}$

"Nergennes to Montmorin, Dec. 1, ib., 583, footnote. See also note 18 , above.

${ }^{22}$ Same to same, Dec. 4 and Dec. 24, ib., 595 and 599. 
In his despatch of December 24th to Montmorin, Vergennes, though still insisting that the Peace of Vervins afforded no precedent, yet indicated that France would be willing to consent, either to the Americans "treating directly and alone with England, under the express condition, however, that the treaty shall keep pace with our own and that each treaty shall be null and roid until the other is concluded"; or, to a long truce between Congress and Great Britain which should leave France at liberty to make a definitive treaty. In either erent the negotiations should proceed under the mediation of the Catholic king, and England should treat with the Americans as if they were independent and should at once withdraw her forces from "all parts of the American continent comprised in the Confederation": and the truce, were there one, should run for from twenty to fifty years and be guaranteed by France and Spain, or at least the former. Franklin, Vergennes added, had been prepared for "an imperfect recognition of the indepenience of his country" but not his associates, for in them "I do not have the greatest confidence." "3 'The day following Vergennes wrote Gérard, the French representative at Philadelphia, to prepare Congress for a truce and indirect recognition. "The matter was to be handled "with dexterity" and the unalterable disposition of the king to

"The deopateh of Inec. $21, i b ., 596 j-9,603-3$. 
sustain all his engagements was to be unremittingly insisted upon. ${ }^{24}$

'Thus was the first concession registered at the expense of His Most Christian Majesty's engagements with the United States to the program of getting Spain into the war, and others were to follow. There was now of course no question of bringing Spain into the autumn campaign, for that had long since closed, but Vergennes, who was already finding the Americans disappointing allies, was now becoming fearful that even the spring would find the Escurial still balancing and undecided. On December 5th the secretary presented the king a second memoir on the subject nearest his heart:

If it is a fact [he wrote] that Your Majesty cannot alone long sustain a contest with the English on equal terms and that the war unduly prolonged would involve both Your Majesty's commerce and finances in ruin, . . . then it necessarily follows that everything advises our risking something in order to bring this ally to the desired point of reunion with us. I do not conceal the fact, Sire, that the pretentions and expectations of Spain are gigantic, but it is necessary to consider that the time one would employ in opposing them would be lost for the establishment of that concert of operations which cannot be effected too promptly. ${ }^{25}$

'Three weeks later, in the same despatch in which he announced to Montmorin the French govern-

${ }^{24} I b ., 613-5$.

216 , 588-90. For Vergennes' view of the Americans at this date, see note $\tau$, ahove. 
ment's willingness to accept a truce for the United States, Vergemnes wrote further that, despite the vast difference between the general situation as it existed at the opening of the war, when England would have been fairly "at the knees of the two crowns," and now when she had had time to fortify all her possessions, His Majesty "approved in advance all that the king his uncle should deem it right and fitting to exact." 26

But a vague disposition of concession was not what Florida Blanca was after,- this must precipitate itself in a shower of definite, concrete stipulations, and particularly must the objects be named for which France would fight to the cnd. And what is even more important, with the possibility of a truce between England and the Americans to be guaranteed by France and Spain, the mediation project was still worth coddling for its own sake. In his despatehes of January 12th and 13th, Montmorin told Vergemnes that he had sought in vain to secure Florida Blanca's views in detail of the advantages which France and Spain might expect to obtain from the war with England. "At that point the prime minister had placed his lever, there he had anchored solidly." "His Catholic Majesty," the Spanish minister's own plea had rum, "wished to show his nephew the sante measure of eonfidence that the latter had shown him. He accordingly

${ }^{28} 1 b, 60 \tau-8$. 
desired that His Most Christian Majesty should be the one to specify the conditions without which he rould promise not to consent to peace." Montmorin's own opinion was that a convention guaranteeing Spain the possession of Mobile and Pensacola, the expulsion of the English from Honduras, and the restitution of Gibraltar would be signed promptly if mediation failed, and that Jamaica was no longer an object. At the same time he noted that, according to Florida Blanca at least, the king still preferred peace and that consequently it still remained necessary to "allay the scruples that were to be anticipated from a conscience at once so delicate and so timorous.",27

But all things end, and the term of Spain's racillations-always more apparent than realwas at last nigh at hand. On February 12th Vergennes sent Montmorin the desired draft of a convention together with full powers to agree "to any modifications or additions that might seem needful.". 'The keystone of the project was its third article which reiterated the stipulation of the Family Compact that neither party should make peace without the consent of the other. 'The fourth article further pledged both parties not to make peace till Great Britain should recognize American independence. The fifth declared

$\approx I b ., 641-3$. See also the letter from Florida Blanca to Vergennes, of .Jin. 13, 1779, ib., 681-3.

Fb., 68.;. 
certain additional objectives of a successful war that would be of interest to France, including the restoration to His Most Christian Majesty of the right to build such works at Dunkirk as he chose and the expulsion of the Fnglish from Newfoundland. 'The sixth article pledged France, in case she shonld regain Newfoundland, to admit Spanish subjects to the fisheries there. The seventh enumerated the objects of interest to spain, to wit. those that Montmorin had listed in his report. ${ }^{29}$

Florida Blanca's reception of the proposed convention was at first apparently cordial but he soon developed numerous criticisms, and particularly against the fourth article; and finally he proposed that he be allowed to draw up a project of his own." Spain's policy, wrote Montmorin, is "to exact everything and accord nothing"; yet, he added, it is only by adopting her terms that we (an bring her in. "I have need of patience "a-plenty." ".1 Vergennes in reply professed some surprise at the attitude taken by the Spanish minister toward "a work that was in some sort more his own than ours," yet he continued: "We are literally committed to onitting nothing that may appear to enlist the interest of Spain." Some of the difficulties that had been raised he was dis-

\footnotetext{
"Ih., 803-10, le'ft hand column.

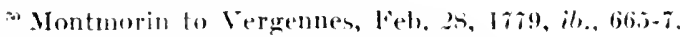

"Same to same, same date, ih., biti?.
} 
posed to attribute to Florida Blanca's faults of temper, on which he heartily commiserated the young ambassador. Nor was he greatly astonished at the repugnance which the Spanish minister had expressed against recognizing American independence at present: "From Spain nothing is to be got for nothing: we have from her directly that she wishes some advantages from the Americans as well as from us, and we will not oppose her." At the same time, Vergennes thought some reference ought to be made to the secret article of the American treaty; for even though the convention with Spain would also be secret when entered upon, yet in time it would see daylight, and then "the glory and honor of the king would suffer if it appeared that he had neglected this ally, and that in order to gain the powerful protection of the crown of Spain." In short, any proposition would be approved of provided that "by the general tenor of the act we have not neglected the interests of this republic." ${ }^{2}$

On April 12th, 1779, the secret Convention of Aranjuez was signed by Florida Blanca and Montmorin. 'The first article declared the intention of the Catholic king, in the event that His Britannic Majesty rejected the ultimatum of the third of the month offering Spain's friendly offices for the last time, of making common cause with His Most Christian Majesty against Great

${ }^{32}$ Vergennes to Montmorin, Mar. 19, ib., 670-2. 
Britain. 'The third, fifth, sixth, and seventh articles were essentially the same as the corresponding articles in Vergennes' project. 'The fourth article, on the other hand, was very different. Diligently recording the fact that the king of France had "proposed and demanded that the Catholie king should from the day when war should be declared against England recognize the independence and sovereignty of the United States and offer not to lay down his arms until that independence should be obtained," it reserved to the Catholic king the right to eonclude for himself a treaty with the Americans to govern "their reciprocal interests," the sole condition being that, to any treaty made by Spain with or affecting France's ally, Louis should also be a party. The article was well understood on both sides to be mere banality. More than a fortnight before this Florida Blanca had confided to Montmorin, who in turn had confided it to Vergennes, that the Spanish monarch, fearful of the "example he would give his own possessions," would "not recognize the independence of the United States until the Fnglish themselves should be forced to do so by a treaty of peace." ${ }^{33}$ Finally, article IX of the convention read thus:

Their Catholie and Most Christian Majesties promise to make every effort to procure and acquire for themselves all the advantages above enmerated and to con-

3.: 16.753 for : 
timue their eftorts unt il they have obtained the end which they propone to one another. mutually pledging themselves mot to lay down their ams nor to make any treats of peace, truce, or suspension of hostilities without having at least obtained . . the restitution of Gibraltal and the abolition of the treaties relative to the fortifieation of Dunkirk, or in defiult of this lant some other object to the taste of 11 is Most chrintian Majesty.:

: $16 . .510: 3-10$. 


\section{CHAP'TER IX}

TIE, TWO AIIIANCES COMPARED

Spain was at last committed-conditionally! We may then, without anticipating much that is to follow, proceed to consider the question already suggested, of how far France was forced, in the interest of bringing Spain into the war with England-and later, of keeping her thereto modify her obligations with the United States as defined by the 'Treaty of February 6th, 1778. The most interesting phase of this question is that touching the direct clash of interests of the United States and Spain along the Mississippi river, and this we reserve for fuller treatment in the chapters to follow. At the moment we have to review some lesser consequences of the necessity which Vergennes finally found himself under, of yoking his government to two more or less antagonistic allies instead of, as he had originally hoped, to governments themselves allied.

The question of the shape which British recognition of American independence should take has already been touched upon. By the 'Treaty of February bth British recognition was to be either 
formal or tacit, but in either case it was to be by a peace ending the zar. ${ }^{1}$ By the Spanish proposition, however, which Vergennes, after some hesitation, finally adopted and transmitted to Gérard with orders to obtain Congress' assent to it, a truce to run for a term of years and to be accompanied by the actual withdrawal of British forces from the territory of the United States was to count as a fulfilment of the purpose of the alliance, provided that France continued to guarantee American independence or that France and Spain jointly guaranteed it. In point of fact Gérard received the orders referred to at an embarrassing moment and in consequence presented his case so feebly that Congress in its Instructions of August 14th, 1779, made no declaration on the subject of a truce. ${ }^{2}$ Not till June, 1781, in circumstances to be reviewed later, did Congress formally declare its assent to the idea of a truce which should be accompanied by a British evacuation of all territory of the United States. ${ }^{3}$

${ }^{1}$ Treaty of Alliance, art. VIII.

"Indeed, by the Instructions of this date "The commissioner to be appointed to negotiate a treaty of peace with Great Britain" was ordered "to make it a preliminary article to any negotiation that Great Britain shall agree to treat with the United States as sovereign, free and independent." Journals of the Continental ('ongress, XIV. 956.

${ }^{3} \mathrm{Op}$. rit., XX. 652. "If a difficulty should arise in the course of the negotiation for peace, from the backwardness of 13 ritain to make a formal acknowledgment of our independence, you are at 
The concession demanded of Congress in the matter of British recognition owed its origin, though not its later repetition, to the necessity that France thought herself under at the end of 1778 of supporting Spanish mediation. Inducements more directly designed to bring Spain into the war against England were, first, the promise by France in the 'Treaty of Aranjuez, in the event of the conquest of Newfoundland from Great Britain, of a share in the fisheries there, and secondly, the listing of the Floridas as objects of Spanish ambition. Though the Floridas, in significant distinction to "the northern parts of America," were not specifically mentioned in the American treaty, it was acknowledged by Vergennes in his instructions to Gérard of March 29 th, 1778 , that they entered "into the plans of conquest of the Americans." Gérard was accordingly instructed more than a year before the 'Treaty of Aranjuez was signed, in view of Spain's well-understood desire to restore her monopoly over commerce on the Gulf of Mexico, "to prepare them for an eventual withdrawal"; or, if he was not able to obtain this-and it was recognized that the matter was one that would "require all the dexterity of M. Gérard"-he should at least "exert himself to obtain Pensacola liherty to agree to a truce, or to make such other concession as may not affect the substance of what we contend for ; and provided that Great Britain be not left in possession of any part of the thirteen United States." 
and the parts of the coast which will be estimated to be of the greatest value to the court of Madricl." Gérard did as he was told, but again his efforts met with little success, as meantime the Florida and Mississippi questions had become merged. Eventually, in 1780 and 1781, Spain went ahead and conquered the British posts in Florida for herself,-without American aid, it is true, but also without American protest. ${ }^{5}$

'The reason for the French government's taking the United States into its confidence with reference to the Floridas is to be found in articles VI and XI of the 'Treaty of Alliance. Under the latter, if the United States had conquered this region and obtained its cession from Great Britain, France would have been bound to guarantee them in its possession. By the former, His Most Christian Majesty had "forever renounced possession of any part of the continent of North America" which had previously belonged to Great Britain, a stipulation which naturally carried

"Menoire pour servir d'Instruction au sir. Gérard," ete, "Approuvé," NIar. 29, 1778, Doniol, III. 153-7: see pp. 155-6. See also Montmorin to Vergennes, Oct. 15, ib., 556. From the latter document it appears that Florida Blanca was willing at this date to see all of the Floridas go to the Americans except such part as was necessarily for the security of Spain's "navigation in the Gulf of Mexico," i.e., probahly for the security of Spain's monopoly of trade on the Gulf.

'Other phases of the Florida question are treated of in the chapters following, in connection with the Mississippi question and Jay's residence in Spain. 
with it the further idea that His Majesty was not free to tender, even contingently, any portion of this continent to another power in consideration for a treaty therewith. But if this was the case with the Floridas, then why was it not also the case with Newfoundland? Yet in article V of the Convention of Aranjuez "the expulsion of the English from the island and fisheries of Newfoundland" is listed as one of the advantages which France sought by the war, while in article VI it is agreed that if His Most Christian Majesty "succeeds in becoming master and acquiring possession of the island of Newfoundland, the subjects of His Catholic Majesty are to be admitted to the fisheries." Evidently the Foreign Office interpreted the term "continent" of article VI of the Treaty of Alliance rather strictly, although it does not seem to have taken Congress into its confidence in the matter. And while the representatives of the French government at Philadelphia frankly combatted the idea from the first that the Americans were entitled of prescriptive right to continue to enjoy that participation in the fisheries which was theirs as British subjects, they always did so on the ground that France ought not to be asked to assume fresh obligations the discharge of which might delay peace. $^{6}$

' But while the French government did not inform Congress of its views in this matter, it probably did so inform the American 


\section{And from the fisheries one turns readily to} Canada and Nova Scotia, to which the self-denying ordinance registered by France in article VI of the 'Treaty of Alliance bore especial reference. ${ }^{7}$

commissioners. Thus Lee records in his "Journal" that, in view of the ambiguity of the word "continent" in article Vl, he, with the approval of Franklin and Deanc framed an additional clause by which France was also to renounce the right to all conquests "in the islands of Newfoundland, Cape Bréton, St. John's Anticosti, and the Bermudas." Lee's Lee, I. 378-9, 383. In the final treaty the Bermudas alone are mentioned in this connection. It ought to be recalled that by the Peace of 1763 Spain had lost her share of the Newfoundland fisheries, while France had retained hers.

${ }^{\gamma}$ See Vergennes to Guines, Aug. 7, 1775, with reference to the instructions to be given Bonvouloir. One point that he should be clear about, say's the secretary, is to reassure the Americans "contre la frayeur qu'on cherchera sans doute à leur donner de nous. Le Canada est le point jaloux pour eux, il faut leur faire entendre que nous n'y songeons point du tout." Doniol, I. 156. See also his comment on Miralles' suggestion that, while Spain recovered the Floridas, France should seek to recover Canada: "Vous savez que nous sommes d'une opinion contraire, parceque nos possessions sur le continent de l'Amerique ne seroient propres qu'à inspirer de la méfiance aux Américains et qu'à les raprocher insensiblement de la Grande-Bretagne." Vergennes to Gérard, Oct. 26, 1778, ib., III. 570. Earlier Vergennes had offered the same objection to Florida Blanca's plan of intervention, the purpose of which for France was to be the recovery of what she had lost in 1763: "La France a des colonies dans la proportion qui convient à sa population et à son industrie. Plus seroit une charge plutôt q'un benefice. Si la perte du Canada a été sensible clle doit la moins regrettér depuis que l'ahandon qu'elle a été obligée d'en faire est devenu le signal de la revolte des provinces angloises sur le continent. Si nous tentions de nons y reintegrer nous reveillerons les anciennes inquietudes et jalousies qui faisoient le gage de la fidelité et de la sounission de ces mêmes provinces à l'Augleterre; leur veritalıle façon de pensér est 
Indeed, by article $r$ of the same treaty, as I have just mentioned, the expectation of the United States to attempt the reduction of what British power remained in "the northern parts of America" is formally recorded. From the very outset, nevertheless, the French government was determined, if not to thwart, at least to discourage in every way possible, this expectation on the part of its ally. Vergennes' own plan for Canada and Nora Scotia originally was to expel the English thence and establish there a free "agricultural and commercial state which should govern itself under the protection of France" and enjoy reciprocal naturalization and commercial privileges with it. In this way, he argued, the eountry would be peopled by the French themselves and "by any who choose to go there," and a national spirit, grounded on similarity of language, customs, and national character and kept alive by constant intercourse, would be created substantially identical with that of France herself. 'Thus would France raise up to herself an ally which, without being burdensome to her

déeouvert dans les propositions quelles nous ont fait parvenir: elles ne sefforcent pas de secoiier le joug de leur patrie pour sexposér à subir celui de tonte antre puissance." Iatter to the king of Apr. 26,1777 , ib., II. $274-5$. See also ib., I11. 62-3 and 5:7, where France's indifference to territorial accuisitions of ally sort is insisted upon. It is interesting to regard article VI of the Treaty of Alliance as a sort of forerunner of that phase of the Monroe Ioctrine which declares that "the American continent is no longer subject to colonization." 
would yet avail to protect the French interests in the Newfoundland fisheries and to check the new republic to the south. ${ }^{8}$

But this apparently was the dream of a moment. ${ }^{9}$ At any rate, by the beginning of $\mathbf{1 7 7 8}$ Vergennes had come to believe that, to furnish the necessary make-weight to the United States, Canada and Nova Scotia should be left with Great Britain. In Gérard's instructions we accordingly read that, though Congress has much at heart the project of a conquest of Canada, Nova Scotia, and the Floridas and would like to obtain an agreement with France looking to the carrying out of these projects, the

king has come to the conclusion that the possession of these three countries, or at least of Canada, by England would be a valuable source of uneasiness and vigilance to the Americans, that it would make them feel the need

- Aranda to Grimaldi, Oct. 10, 1776, Sparks MSS., CII. Aranda also quotes Vergennes as saying that France herself "would not again occupy anything more than the islands to the north of the St. Lawrence."

'See, bowever, Estaing's “Addresse à tous anciens François de l'Amérique septentrionale" of Oct., 1778: "I shall not urge a whole people that to join the United States is to secure their own happiness; since a whole people... must know their own interest; but I will declare and I now formally declare in the name of His Majesty ... that all his former subjects in North America who shall no more acknowledge the supremacy of Great Britain may depend upon his protection and support." The Continental Journal and Weekly Advertiser (Boston), Dec. 3, 1778. See further, Doniol, III. 417-25. 
they have of the friendship and alliance of the king, and that it is not to his interest to destroy such a feeling. ${ }^{10}$

In the views thus expressed Vergennes was fortified in the course of the months following by the similar views communicated in Spain's behalf by Montmorin. ${ }^{11}$ As it chanced, however, at this very time La Fayette was perfecting in conjunction with a committee of Congress a plan for a joint campaign in Canada by the allies. Commenting upon the plan, Vergennes wrote Gérard thus: "I will confide to you, but to yourself alone, that the opinion of Spain is that it will be advantageous to reserve Canada and Acadia to Great Britain, and you feel yourself that we ought to be far from contradicting her.... But, I repeat, it is for circumstances to confirm or modify our views." ${ }^{2}$ The final disposition of

${ }^{10} \mathrm{Ib}$., III. 156-7. Note also the extracts furnished by the Count d'Estaing from his Instructions, to Gérard: "7 chef-Requis que je dois faire de contribuer à la conqueste du Canada autrement que par une croisère et par des attaques des posttes...

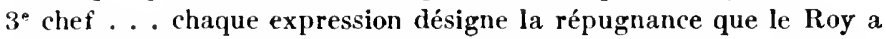
pour cette enterprise." Ib., 237-9. See also Vergennes to Montmorin, Oct. 30: "Nous ne désirons pas à beaucoup près que la nouvelle république qui s'élève demeure maîtresse exclusive de tout cet immense continent." Accordingly Canada and Nova Scotia should remain with England in order to make the Americans feel the need "de s'assurér des garants, des alliés, et des protecteurs." $I b ., 561$. See also SMSS., Nos. 872 and 891.

${ }^{11} I b ., 557$ and 616 .

${ }^{12}$ Nov. 18, 1778, ib., IV. 43 footnote 3 ; and to same effect is $i b$., III. 616. See also Adolphe de Circourt, Histoire de Illiance et de l'Action commune de la France et de l'Amérique (Paris, 1876, 
the question was somewhat curious. The plan mentioned having been referred to Washington, the commander-in-chief reported against it. Officially and publicly he based his objection upon the impossibility of furnishing sufficient forces for the expedition, but in a confidential letter to the president of Congress he also voiced the fear of offering France the temptation of reëstablishing her power in a country filled with the memory of her, whose customs, morals, religion, habits of government, everything, recalled her, and the possession of which would be valuable to her in many ways, especially in the facility it would afford "of controlling these states, the natural and most formidable rival of every maritime power in Europe." ${ }^{\prime 3}$

But after all, Canada, the Floridas, the fish-

3 vols.). The work is a translation of vol. $\mathrm{X}$ of Bancroft's History, of the edition of 1874, with added notes and documents. Here, vol. III. pp. 263-4, Vergennes, writing Gérard under date of Dec. 25, 1778, says: "You have done wisely to elude the overtures made you concerning Halifax and Quebec. Your instructions embody the king's way of thinking upon this subject; and His Majesty has changed the less because he has reason to believe that it enters into the policy of Spain as well as in ours, to maintain the English in possession of Nova Scotia and of Canada." I. Doniol would make Spain originally responsible for the idea of leaving Canada in England's hands, lut in this he is clearly inistaken.

${ }^{13}$ Washington the President of Congress, Nov. 14, 1778, Writings of Washington (Ed. Sparks, Boston, 1834, IQ vs.), YI. 106-10. Iater, however, Washington changed his opinion on this subject. See Doniol. IV. 565: also ch. XIII, infra. 
eries, and even the form that British recognition should take, are matters more or less by the way. For either France did not transgress her engagements with the United States with reference to them, at least to any very easily definable extent, or else she candidly took the United States into her confidenee and asked their coöperation. 'The one point, and the only one, at which there was flat incompatibility, technically at least, between the 'Treaty of February 6th, 1778, and the engagements subsequently incurred by His Most Christian Majesty with Spain was the stipulation by the secret Convention of Aranjuez, that France should make no peace without the eonsent of Spain, which was fortified by the further and more definite stipulation that the war should continue until His Catholic Majesty had obtained Gibraltar. 'Thus was the purpose of the war, in which the United States were already bound to remain to the end, altered and enlarged, not only without their consent, but without their knowledge. ${ }^{14}$ Having failed in her efforts to ally with one another the powers with which she herself was allied, France bound the two to one another's fortunes by conditioning peace-making in all cases upon her own consent, but while the relation thus created between France and the United States was known to Spain, the analo-

"That it was the purport of Florida Blanca's program to "alter the object of the war" is stated by Montmorin, ib., III. 487. 
gous relation between Spain and France was unknown to the United States.

And this discrepancy, of which the United States were contingently the victim, is thrown into even higher light when we turn to the history of M. Gérard's early months at Philadelphia. Here Louis' representative found upon his arrival a widespread belief that the United States could make peace at any time with England, provided only they did not renounce their independence. ${ }^{15}$ The source of the idea is not far to seek. It was the commissioners' letter of December 18th, which was written at the period when the French government was negotiating 'for the amity and commerce of the Colonies, but not their active alliance. But the later treaty, which however in July had not yet been published in America, proceeded of course along quite different lines. As soon, therefore, as Vergennes learned the state of belief in the United States on the subject of peace-making, as he did from some American newspapers even before Gérard had reached Philadelphia, he penned the latter a despatch ordering him preemptorily to "destroy an opinion... which would reverse the whole system upon which our 'Treaty of Alliance rests." ${ }^{16}$

'This despatch reached Gérard early in August.

${ }^{10} I b .$, III. 277-84.

${ }^{10} \mathrm{Ib}$., 234. See further $i b ., 399-401$, and IV. 17-34. 
At the same moment, with the arrival of Deane in Philadelphia, whither he had been summoned by Congress, the famous Deane-Lee controversy broke forth, over the question whether the Colonies were under any obligation to pay for the supplies that had been furnished them through Hortalez and Company. Deane, who had made a contract with Beaumarchais guaranteeing payment, contended that Congress was bound to live up to this agreement, while Lee asserted that these supplies had been intended by the French government as gratuities and that Hortalez and Company had been a mere device to conceal French assistance under the guise of commerce, and further insinuated that Deane and Beaumarchais were in conspiracy to defraud Congress. ${ }^{17}$ The merits of the controversy are divided. Lee was certainly right as to the supplies purchased with the money that had been contributed by the Bourbon kings, ${ }^{18}$ but was quite

${ }^{17}$ For references on this topic see Chapter III. notes 27 and 42; also Letters of Richard Henry Lee (Ed. J. C. Ballagh, N. Y., $1911-4,2$ vols.), I. 373-5, 457-63, II. 1-903, passim.

"Note in this connection the following words from Iouis" letter to Charles, of January 8, 1778: "Je ne parle pas des secours d'argent et autres, que nous leurs avons donnés, le tout étant passé sur le compte du commerce." Doniol, II. 713. The king's intention, therefore, with reference to the million livres which were entrusted to Beaumarchais in June, 1776, seems clear: he meant it as a gift to the Colonies. Vergennes, on the other hand, was perhaps not mnwilling that Beaumarchais should have it, in return for his services to the Foreign Office. See Wharton, I. 376-8t; also, M. D. Conway in the Athenaeum, 1900, pt. I. 305-7. 
unwarrantably suspicious of Deane's motives, while Deane was right as to the balance of the supplies, which was a considerable one. The French government, however, which at this very moment was defending itself before Europe against the indignant charges of the British government, of having clandestinely aided the Colonies while the two powers were still ostensibly at peace, could not afford to admit that Lee was right to any extent. 'The result was that Gérard soon took up the cudgels for Deane, with the natural result of offending Lee's brother, Richard Henry, who revenged himself by blocking all the envoy's attempts to get a declaration from Congress on the subject of a separate peace. ${ }^{18^{2}}$ Fortunately for Gérard, early in January 'Thomas Paine, who was secretary of Congress, published some articles in the Pennsylvania Packet, sustaining Lee's case with citations from official documents, which action forced Congress to declare its position on both issues at once. On January 12th, accordingly, it passed a resolution disavowing Paine's lucubrations and declaring

is For Lee's change of opinion of Gerard in consequence of the latter's intervention in hehalf of Deane, $v d$. his Letters, I. 423 , 427, II. 114, 119-20, and 124. Gérard's endeavor, however, to fasten upon Lee the stigma of disloyalty to the alliance falls flat in light of the evidence. See especially lee's letter of December 16, 1778, to the Pennsylenia General Advertiser, ib., 45762, where he satisfactorily explains his relations with the British agent Berkenhout and his sentinents on the subject of a separate peace. 
itself convinced "by the most indisputable evidence" that the supplies furnished by Hortalez and Company "were not a present" and that "His Most Christian Majesty . . . did not preface his alliance with any supplies whatever sent to America"; and two days later it disavowed explicitly the notion of a separate peace. ${ }^{19}$

In other words, it was settled, and by the strenuous insistence of the French government itself, that Congress could agree to no peace or truce

${ }^{19}$ Journals of the continental Congress, XIII. 51-5, 62-3. "Whereas it hath been represented to this House by the llon. Sieur Gérard, minister plenipotentiary of France, "that it is pretended the Lnited States have preserved the liberty of treating with Great Britain separately from their ally, as long as Great Britain shall not have deelared war against the king, his master"; therefore, Resolved, unanimously, That as neither France or these United States may of right, so these United States will not, conclude either truce or peace with the common enemy, without the formal consent of their ally first olntained." It will be noted that the advocates of a seprate peace finally based their case on the fact that there had never been a formal declaration of war upon France by Great Britain. The resolution which Gerard hat desired to see adopted reprohated the endemned opinion very strongly, but it was superseded by the resolution just quoted, 1. 62. The action of Congress, nevertheless, elicited some criticism. Thus a writer in the Penusylmania Packet of Mal. 18, 1769, while denouncing the Ices as men of "base principles," charges that M. Cierard has altered the l'reaty of Alliance from its original form. The charge is repeated in the same jommal of $A_{p}$ r. 8. where great disfaror is expressed with the treaty with irance as compared with the one published "in our papers" nine nonths carlier. "In the first treaty, ly one of the articles America had the right to withelraw herself from the war, provided she did not relinguish her independence." 
with Great Britain-though it might "listen to overtures"- without the consent of France; while three months later, France agreed, in turn, that she would not consent to such a peace or truce till Spain would do the same, or at any rate, till Spain had obtained Gibraltar. Nor is M. Doniol's contention that the two developments were quite unconnected in the conscious intention of the French government necessarily sound simply because the Congressional interpretation of the Treaty of February 6th came first, since Vergennes was well aware from a much earlier date that Spain would enter the war only on condition that her objectives be made a sine quâ non of peace. And that the two developments were connected in practical effect is obvious.

But, then, did the French government by acceding to the Treaty of Aranjuez commit anything worse than a merely technical breach of its engagements with the United States? Did it not, on the contrary, take a step that was actually beneficial to the United States in forwarding the cause of independence? For though Spain herself was not allied with the United States, yet once she had entered the war her forces were turned against the common enemy. To begin with, I think it highly questionable whether, all things considered, Spanish aid really paid for itself. 'Thus the opportunities of the campaign

${ }^{19}$ Doniol, III. 762, fn. 2 . 
of 1778, when American enthusiasm for the alliance was fresh and the new French marine was in the pink of condition, were frittered away to no small extent because of the French government's efforts to accommodate its course to the exigencies of the Spanish monarch's whimsy mediation. ${ }^{20}$ Again, the campaign of 1779 netted nothing, largely because France yielded again to Spain's views, which were for an invasion of England. ${ }^{21}$ Again, in 1780 Spain, save for the forces she maintained at Minorca, in the Floridas, and along the Mississippi, was practically out of the war. ${ }^{22}$ Only in 1781, when the siege of Gibraltar was formed, was Spain's assistance more than negligible, when indeed it was not worse. In short, Montmorin's prediction that Spain's demands would be more embarrassing than her help was worth was substantially fulnilled. ${ }^{23}$

Waiving, however, the question of the value of Spanish aid, can it yet be contended that the Convention of Aranjuez signified any real danger to American interests? Verbally the United

${ }^{20}$ See, for instance, Montmorin to Vergennes, June $22,1778, i b$, 472-3; also ib., 503-7 and 590 .

"Ib., IV. 322-4. Florida Blanea was of the opinion that "it was possible to strike the English so they would feel it only in England," $i b$., III. 674. Charles III was convinced that the war must begin with a grand coup such as a descent upon England, $i b$., 665. See also I lorida Blanca's plan of operations of Feb. 26, 1779, ib., 688-91. For 1, a Fayette's connection with the plan of descent and the failure of the project, see ib., IV. ch. V.

2 The spanish esurt was at this time engaged in informal and 
States were bound by article VIII of the Treaty of Alliance not to make peace till France gave the word, but morally their obligation would be fulfilled the moment Great Britain was willing to accord them independence and their ally an unconditional peace; and certainly Vergennes himself must have foreseen that the Americans, despite the secrecy of the Treaty of Aranjuez, would not be easily hoodwinked into prolonging the war once England manifested a disposition to grant the terms just described. The real danger of the Convention of Aranjuez from the point of view of American interests sprang from its secrecy taken in connection with the fact that France was to exert a powerful influence upon

unavowed negotiations with the English enissary Richard Cumherland, Lord George Germaine's private secretary. See ch. XII, infra.

${ }^{23}$ For a rather more farorable estimate of Spanish participation in the war, see Francois Roussean in Revue des Questions historiques, IXXII. 444 ff. See also Florida Blanca's "Apology" for his administration, William Coxe, Memoirs of the Kings of Spain (I,ondon, 1813, 3 vols.), I. App., 331-44. Even in Congress, which on the whole was not favorably disposed toward her, Spain had one or two defenders. Thus we find Witherspoon of New Jersey saying, in Aug., 1782: "Some gentlemen had underrated the services of Spain. She had done much. She had entered into the war with the common enemy. We had derived as much advantage from her exertions as if she had agreed to the treaty of Alliance. ... Besides this she had aided us with money, opened her ports, and admitted us to trade to Havannah," Thomson Papers (N. Y. Hist'l Soc. Cols., 1878), pp. 90-1. See also a speech by Madison to much the same effect early in 1783, Writings (Ed. Hunt), I. 418-9. 
Congress in shaping the terms upon which that body would consent to peace. For at the outset it was a compensating consideration that, in proportion as Vergennes had insisted upon the indispensability of France's consent to America's making peace, so by the same token, he had insisted upon the indispensability of America's consent to France's making peace, and had therefore bound himself to give respectful heed to the American interpretation of the reciprocal engagements of the allies. Eventually, however, by the Instructions of June 15th, 1781, Congress surrendered outright to the French ministers the control thus given it over the final peace. There can be little doubt, I think, that Congress' ignorance of the Treaty of Aranjuez ought to be reckoned as one of the circunstances explaining this surrender. ${ }^{24}$

The issue thus finally becomes whether the Instructions of June 15th were in the circumstances a menace to American interests-and this issue can wait. For the moment, we turn back to review briefly the story of the ultimatum of April 3rd, 1779, upon the rejection of which by Great Britain the Convention of Aranjuez still left Spain's entrance into the war contingent.

Great Britain's answer to the suggestion of a " See Chapter XIII, infra. 
truce involving a tacit recognition of American independence and her evacuation of American territory did not reach Madrid till March 27th, but when it at last arrived it was found to be explicit to the point of insult: Great Britain could not recognize the right of France "to confound her own affairs with the pretended interests of those whom she affects to call her allies," or to dictate "in what manner His Britannic Majesty should exercise his liberty of reëstablishing his authority over his own dominions." ${ }^{25}$ Yet notwithstanding this language, which he admitted was "hardly satisfactory," Florida Blanca, pleading as always the necessity of continuing the deception of England, ${ }^{26}$ proceeded to draft the ultimatum just referred to. In essence, what this ultimatum proposed was a truce of indefinite duration in America during the continuance of which England should remain in possession of the territory she still held there, including New York City and Rhode Island. ${ }^{27}$ Vergennes' dismay at these propositions, when he learned of them on April 12th, may be imagined: "The more we examine them and weigh them," he wrote Montmorin, "the less do we see any way of reconciling them with what the king owes himself or his new allies." Nor, unfortunately was this the worst of the matter, for by leaving the British forces mingled with the American population at

Doniol, III. 746-8.

Ib., 748-9.

${ }^{27}$ Montmorin to Vergennes, Mar. 29, ib., 798-9. 
some of its most important centers, the Spanish proposals still kept open a way for England's conciliation of her alienated subjects. "Endeavor, I pray you," he continued earnestly, "to prevent any further condescensions of the sort, for they can only be fatal to the dignity of the king, and the humiliation resulting from them the king his uncle will necessarily share." ${ }^{28}$ On April 12th, 20th, and 29th and again on May 14th, Vergennes gave vent to vehement and even bitter protestations against the action that the Spanish government had so unwarrantably taken, in the very face of its repeated promise "to guard the honor of France as it would that of its own crown and country." 29 But one thing Vergennes had not eounted upon-the obstinacy of the king of England, who, blissfully unaware that he had been presented with the opportunity of shattering not only the French-American alliance but the Family Compact as well, still adhered to his resolution to bring his rebellious subjects to their knees. On May 17th, Montmorin, breathing a sigh of relief, wrote Vergennes that England had repelled the Spanish ultimatum and that the Spanish fleet would soon join the French. Yet Montmorin's despatch containing this welcome news sounded also the now familiar note of warning: "We ought however not conceal from our-

${ }^{2 *} 16,967-8$.

to Loce cit. and pp. 770 and 801-3. 
selves, Monsieur, how little interest Spain takes in the United States of America; we shall certainly have evidence of this in the course of the war but especially when the question shall arise of concluding peace." ${ }^{\prime 30}$

${ }^{30} \mathrm{Ib}$, , 771. Beaumarchais in writing Vergennes commented upon Spain's entry into the war in characteristic vein: "Si le livre est aussi fort que la préface a été longue, nous devons voir de belles choses de cette nation-là; mais, je ne sais pourquoi, j’ai toujours un petit glaçon dans le coin de ma cervelle étiqueté Espagne. $J$ 'ai bean faire, je ne parviens pas à échauffer cette idée-là," $i b .$, IV. 446. 


\section{CHAPTER X}

\section{THE MISSISSIPPI AND THE WESTERN LAND QUESTION}

The claim of the United States during the Revolution to extend to the Mississippi was based upon both sentiment and interest. Rebels against the authority of the British Empire could not have taken an impoverished view of their future; and at the beginning of the war at least the spirit of Continentalism, forerunner of Manifest Destiny, was abroad in the land. The Earl of Cork had proclaimed that "the ball of empire was rolling westward and would stop in America" and the propheey was now repeated, while in confirmation of it were cited "the growing millions of western world." 'That such a spirit should treat the idea of being "shut up within the Mountains" with impatience was inevitable. ${ }^{1}$

'The Earl of Cork's words are reminiseent, perhaps, of Bishop Berkeley's famous lines in his essay on The Prospect of Planting Arts and Learning in Amerira:

"Westward the course of empire takes it way;

The first four acts already past,

A fifth shall close the drama with the day:

Time's noblest offspring is the last."

One of the earliest forecasts by an American of the "manifest 


\section{And the view that sprang in the first place from enthusiasm found ready support from sober calculation. The original belief seems to have}

destiny" of this continent was that of John Adams, in a letter written in 1755: "Soon after the Reformation a few people came over into this new world for conscience sake. Perhaps this apparently trivial incident may transfer the great seat of empire into America. It looks likely to me: for if we can remove the turbulent Gallicks, our people, according to exactest computations, will in another century become more numerous than England itself. Should this be the case, since we have, I may say, all the naval stores of the nation in our hands, it will be easy to obtain the mastery of the seas; and then the united force of Europe will not be able to subdue us." Life and Works of John Adams (Boston, 1856, 10 vols.), I. 23. The prophecy of naval supremacy for America is strikingly like that of Vergennes twenty years later: vd. supra, ch. III, 67-8 and note. Less than three years after Adams, James Wolfe was writing his mother from Louisbourg, thus: "These colonies are deeply tinged with the vices and bad qualities of the mother country; and, indeed, many parts of it are peopled with those that the law or necessity has forced upon it. Notwithstanding these disadvantages,... this will, some time hence, be a vast empire, the seat of power and learning." Beckles Willson, The Life and Letters of James Wolfe (London, 1909), p. 395. The outbreak of the Revolution naturally enhanced the vision of imperial greatness entertained by the friends of America. In this connection various expressions in Dr. Richard Price's famous pamphlet entitled Observations on the Nature of Civil Liberty and the Principles of Government and the Justice and Policy of the War with America (London, 1776) are interesting: see pp. $21 \mathrm{ffg}$. Price concludes that, "It is probable that the Americans in fifty or sixty years will be double our number and form a mighty empire consisting of a variety of states, all equal or superior to ourselves." In the same connection an extract from the Antigua Gazette of Sept. 10, 1777, is interesting. In what purports to be a "Circular I etter" delivered by a ministerial messenger to the different foreign ambassadors resident at Lon- 
been, at any rate it was the view of Franklin and Deane, that the lands west of the Mountains were subject to the disposal of Congress to meet the expenses of the common effort. ${ }^{2}$ Later, with

don, warning is given that it is obviously "the common interest of Europe to annihilate America," which is destined to rival all countries in production, to undermine their commerce by means of free navigation, and to draw off their population in the way of emigration. The British territory in America is estimated at 718,592,000 acres, capable of supporting $145,918,400$ people, or twenty-six million more than Europe. The phrase above quoted, "the growing millions of the western world," is from a letter in the Pennsylvania Packet, No. 144, postscript. See also in the same journal, No. 147, an extract from a sermon by John Lathrop, American pastor of the Second Church in Boston: "America has every natural advantage. . . A coast three thousand miles in length and a breadth as yet unexplored... The united wisdom of North America should be collected in a general congress of all the colonies." The date of the sermon was June 6, t774. See also the Boston Evening Post and General Advertiser of June 26,1779 : "We are now upon the stage of America, have an arduous task to perform, we act not only for ourselves hut for remotest posterity. The political misery or happiness of millions unborn depends on the conduct of our public measures at this day." These words occur in a plea in support of the right of Congress "to ascertain and fix the limits of those states that elaim to the Mississippi or South Sea."

2 'The first form of the Articles of Confederation as reported to Congress was in the hand of Franklin. Article XI of this draft provided that all purchases of lands from Indians were to be made only with the consent of Congress, that Congress was to have authority to determine Indian houndaries, and that "all purchases from them [the Indians] by Congress [were to he] for the general advantage and benefl of the United Colonies," Complete Works of Benjamin Franklin. (Ed. Bigelow, N. Y., 1887-8, 10 vols.), V. 552-3. Article XVIII further gave Congress the power to limit "the lyounds of those Colonies which by" charter or proclamation, or under any pretence are said to extend to the 
the rise of the principle of State Sovereignty, narrower views obtained sway and the conviction became general that these lands were the property of particular states. Yet even so, all states still retained an interest in having these lands kept open to settlement by their citizens and in seeing their frontiers secure, both of which objects would have been jeopardized had a foreign power obtained control of the region in question and of the Indian tribes there. Finally, by yet another turn of the wheel of public opinion, from 1781 on the prospect developed that the states credited with the sovereignty and ownership of these lands would surrender their claims to the Confederacy at large. Once more the interest of all states in seeing the American title established became what it originally had been.

What, then, was this title? As I have just hinted, it was twofold: that of the American Peo-

South Sea." This clause gave rise to a debate, Aug. 2,1776 , which marks the beginning of the struggle between the "landless" states, headed by Maryland, and the "landed" states, headed by Virginia, and which ended five years later in the acts of cession of western territory to the Confederacy. Chase of Maryland "denied that any colony has a right to go to the South Sea." Harrison of Virginia thereupon inquired, "How came Maryland by its land, but by its charter," and added: "By its charter, Virginia owns to the South Sea." Huntington of Connecticut was all against "mutilating charters." Stone of Maryland contended for the right of the small colonies to "happiness and security," and that "they would have no safety if the great colonies were not limited." The clause was stricken out in committee. Life and Works of John Adams, II. 501-?. 
ple to the region in question, and that of certain states. True, these two titles were mutually conflicting, and true also, the peculiar titles of some of the states conflicted with those of other states; and doubtless, if the matter were one to be resolved dialectically, this fact would have serjous consequences. 'The question raised, however, is not one of logic but of law; and it has accordingly to be remembered that in the analogous case of real estate, titles that conflict are often consolidated to produce a title that is unimpeachable. It is therefore not inconceivable that while, on the one hand, no state had a perfect title against either the United States or her sister states to western domain, yet, on the other hand, the titles of all parties combined exhausted the legal rights to the region.

'The states that held individual claims to domain west of the Mountains were Massachusetts, Comnecticut, New York, Virginia, the Carolinas, and Georgia. 'The claims of Massachusetts, Connecticut and New York were confined to territory north of the Ohio river; that of Virginia, the most sweeping of all, was to the whole of this territory, and also to the region south of the Ohio that today eomprises the state of Kentucky; those of the Carolinas and Georgia were, roughly, to the lauds lying between their present western bondaries and the Mississippi river. 'The foundation for these claims, save that of New York 


\section{who based hers on a pretended overlordship over} the Iroquois Indians and their conquests, was in all cases furnished by the "sea-to-sea" clauses of the colonial charters as curtailed by the 'Treaty of 1763, which made the Mississippi river the western boundary of British America. ${ }^{3}$ As I

'As noted immediately below, England based her case against France in the dispute leading to the last French and Indian war partly upon the colonial charters, and undoubtedly this dispute more than anything else made the colonies aware and confident of their charter claims to the Mississippi boundary. Yet it is interesting to observe that the English cartographer Bollan complained that his predecessors, Popple (in 1732), Keith (in 1733), Oldmixon (in 1741), Moll (at several dates), and Bowea (in 1747) had all been recreant to British interests, Winsor, Mississippi Basin, p. 331. The rising dispute, however, soon registered itself in the views of the mapmakers. Thus Bowen's map of $\mathbf{1 7 4 9}$ is entitled: "A Map of the British-American Plantations... including all the back settlements in the respective provinces as far as the Mississippi." The famous Mitchell Map of 1755 also recorded British official pretensions, which in turn were supported by citations of Mitchell's and Bowen's maps. On the other hand, Evans' map of the same year set the western boundary of Virginia at the Mountains; while as late as 1777, French mapmakers applied the term "Louisiana" to the region between the Alleghenies and the Mississippi. See generally Winsor's Narrative and Critical Iristory, V. 79-86, and 935. Certain other occurrences also, lying between 1754 and the outbreak of the Revolution, tended to confirm Virginia's charter pretentions. Thus Governor Dinwiddie, in 1754, made promises of land to the Virginia soldiers, while a convocation of the chiefs of the Cherokee and Choctaw Indians at Charleston the same year recognized the right of the Virginia and Carolina governments to establish magazines among them, and certain other rights of apparent suzerainty. The legal significance of the Proclamation of 1763 , restraining settlements westward of the mountains, is doubtful (see infra), but the discussion concerning it was calcu- 
have just pointed out, the fact that these claims in some instances overlapped was not necessarily fatal to them as against third parties. There were other obstacles to their admission, however, that were more formidable.

'The two nations against whose pretensions it was requisite for the states to secure their claims were Spain and Great Britain. The latter power,

lated again to aronse public attention to the question of where the western boundary of the colonies lay. Also, the Proclamation was constantly being transgressed or officially waived. "I have had, my Lord," wrote Iord Dunnore in his Report to I.ord Dartmouth of Decemler 24,1774 , "frequent opportunities to reflect upon the emigrating spirit of the Americans since my arrival to this government. There are considerable bodies of inhahitants settled at greater and less distances from the regular irontiers of, I helieve, all the colonies. In this colony, proclamations have been published from time to time to restrain them; hut inpressed from their earliest infancy with sentiments and habits very different from those acquired by persons of a similar condition in England, they do not conceive that government has any right to forbid their taking possession of a vast tract of country, ather uninhabited or which serves only as a shelter to a few scattered trihes of Indians. Nor can they be easily brought to entertain any belief of the permanent obligation of treaties macle with those people, whom they consider as but little removed from brute creation." R. G. Thwaites and Louise P. Kellogr, Dorumentary History of Dunmore's War, 1. 371. See also ih., PP. 369-70 and footnote 91, also p. 5, footnote 8, for data with reference to the Treaty of liort Stanwix (1768) and the Walpole (irant of 1769 , loth of which transgressed the prineiple of the Proclamation of 1763. On the eve of the Revolution occurred Lord Dummore"s War which gave rise to an acrimonious dispute hetween Dunmore and the proprietary governor of Pennsylvania, John Penn, with reference to Virginia's western clams. It was the forerunner of later disputes, in the course of the lievolution, between the states with fixed western boundaries and 
having urged the charter rights of the colonies in partial support of her own claims against France anterior to the Seven Years' War, was perhaps estopped from denying that those rights had been all that she had once asserted them to be. The 'Treaty of 1763, however, had been followed by the Royal Proclamation of the same year, forbidding the colonial governors to make further grants of land in the region west of the Alleghenies. ${ }^{4}$ The question therefore arises whether

those claiming to extend to the Mississippi. Dunmore, in his Proclamation of Sept. 17, 1774, asserted that Virginia's "ancient claim" was "founded in reason, upon pre-occupancy, and the general acquiescense of all persons," but makes no mention of Virginia's charter rights, Force's American Archives, 4th series, I. 790-1. Finally, in the Virginia Constitution of 1776, it is provided that "the western and northern extent of Virginia shall in all respects stand as fixed by the charter of King James $I$ in the year 1609 and by the public peace between the courts of Great Britain and France in the year 1763." For Virginia's clumpionship of the charter claims and Maryland's opposition to them, see ('ollections of the New York Historical Socicty, 1878 (Thomson Papers), passim.

4 The text of the Proclamation of $\mathbf{1 7 6 3}$ is to be found in the Anuual Register for that year, 1). $208-13$, and in Force's Americun Archives, 4th series, I. 171-5. The salient clause is the following: "We do ... declare it to be our royal will and pleasure ... that no governor or commander-in-chief of our other colonies or plantations in America do presume for the present, and until our further pleasure be known, to grant warrant of survey or pass patents for any lands beyond the heads or sources of any of the rivers which fall into the Atlantic from the west or northwest; or upon any lands whatsoever which, not having been ceded to or purchased by us, as aforesaid, are reserved to the said Indians or any of them." The line actually drawn by Hills- 
it was the purpose of the Proclamation to set a definite western boundary to such provinces as had thus far remained without one. 'The American advocates contended that this was not the case, that the intention of the Proclamation had been "not to take away but to restrain an existing right," of which therefore it furnished formal official recognition." But this opinion, it seems clear,

borough in pursuance of the Proclamation made exception in favor of the Virginia settlements on the Great Kenawha. The ostensihle purpose of the Proclamation was to pacify the Indians, but flillsborough in $170 z$ admitted another motive, viz., to keep the populace under the restraint of the seaboard authorities. A third motive, possibly, was to discredit the colonial charters. Winsor, Mississippi Basin, 430-1. Winsor also implies that the Proclamation met with some contemporary protest. "The party of progress," he says, "called it a tyrannous check on the inevitable expansion of the race." I am rather of opinion, however, that such criticisms came later, when the general argument against England's American policy was being shaped up. This is certainly true of Burke's characterization of the Proclanation, quoted by Winsor as if contemporary, as an attempt "to keep a lair of wild beasts that earth which God, by an express charter, has given to the children of men." IBoth Washington and Franklin regarded the Proclamation to be, as its terms imply, a temporary measure, and this was probably the view generally held of it.

"Livingston to Franklin, Jan. 7, 1782, Wharton, V. 89, This important document is also to be found in the Complete Works of Benjamin Frankliu, VIl. $348 \mathrm{ff}$. Other important statements of the American argument on the territorial question are the "Instructions to Jay" of Oct. 17, 1780, in Journals of the continental Congress, XVIII, $935 \mathrm{ff}$., and Writings of James Madison (Ed, Hont), I. $82 \mathrm{ff}$; and the "F"acts and Ohservations in support of the several claims of the Inited States," presented 
runs counter to the evidence. 'Thus in 1772 , when Franklin and some associates sought a grant from the Privy Council of a tract of land on the Ohio and the argument was brought forward that the proposed grant contained "part of the dominion of Virginia to the south of the river Ohio," it was answered "that no part of the above tract is to the eastward of the Allegheny mountains and that those mountains must be considered as the true westward boundary of Virginia"; and this arguments prevailed with the council. ${ }^{6}$ Two years later moreover the Quebec Act was passed with the proviso "that nothing herein contained relative to the boundary of the province of Quebec shall in any wise affect the boundaries of any other colony," notwithstanding which the southern boundary of the province was drawn along the Ohio. ${ }^{7}$ We may admit the American contention that, since the Quebec Act was itself one of the causes of the Revolution, "to build anything upon it would be to urge one wrong in support of

to Congress, Aug. 16, 1782, Journals of the Continental Congress, XXIII. 471-524, and Thomson Papers, 102-41.

- Complete Works of Benjamin Franklin, V. 3 and 25-35. The opposition to the proposed grant was headed by Lord Hillsborough, President of the Lords of Trade. The authorship of the answer to Hiltsborough's representations is usually ascribed to Franklin, but Professor C. W. Alvord contends that its author was Samuel Wharton of Philadelphia. See the Nation, XCIX. 920-1. Wharton may have stood sponser for the answer and yet Franklin have been the author of it.

${ }^{7}$ Force's American Archives, 4th Series, I. 216-20. 
another." 8 Nevertheless, the evidential value of the act as to the meaning of the Proclamation of 1763 , the validity of which was never questioned, still remains.

And as against Spain the claims of the American states were weaker still. Spain desired, first, to keep the Americans back from her own possessions, and secondly, to restore her monopoly of trade on the Gulf of Mexico; ${ }^{9}$ to both of which ends it was essential that she should withhold from the Americans the right, which in 1763 she had accorded the subjects of Great Britain, ${ }^{10}$ of navi-

- Wharton, V. 88. In the debate on the Quebec Bill, Dunning contended that the measure was inconsistent with England's position in the Seven Years' War. "Consider," he said, "what it was for which you engaged in the last war: encroachments of the French upon our colonies.... You repelled force by force. They offered to you to withdraw from the south of the Ohio and retire to the north, making that river the boundary of the two colonies. No, you replied, the river of St. Lawrence is the houndary of Canada; ... the tracts which you clain are parts of our colonies of Virginia, Pennsylvania, etc.; and we cannot grant away the certain and undoubted right of our subjects in such a manner." Yet this was precisely what Parliament was doing by the Quebec Bill: it was merging with Canada what England had always contended was no part of Canada. The Attorney-General, Thurlow, answered Dunning thus: "It is success in war that gives success in peace, and by no means the imaginary line drawn by a state in its colonies; nor have the limits now drawn anything to do with old Canada; ... it is a new schesue, and by no means a restoration of those old linits the French once contended for." Parliamentary History, XVII. $1359 \mathrm{ff}$.

- See Chapter XIV.

10 Art. V'lI of the Treaty of Feb. 10, 1763: "Provided that the 
gating the Mississippi through Louisiana to its mouth. For by denying the Americans this right, so obviously essential to an agricultural population between the Mountains and the River, she would discourage the further immigration of Americans westward; while she would also be taking an excellent preventive measure against the appearance of American smugglers on the Gulf. And her desire to acquire the left bank of the Mississippi looked to the same ends. She had no use for the region simply as so much territory, but once it was hers, any question of American navigation of the Mississippi would be foreclosed.

But now be it noted that, in order to achieve her purposes in the Mississippi country, all that was necessary for Spain to do at the outset was to assert, not a title of her own to the left bank of the River, but merely that of her enemy, Great Britain, which thereupon of course she would be free to acquire by conquest if she could. She, therefore, no less than Great Britain, was able to plead in her behalf the Proclamation of 1763, while, unlike Great Britain, she was not estopped navigation of the river Mississippi shall be equally free, as well to the subjects of Great Britain as to those of France, in its whole breadth and length, from its source to the sea, and expressly that part which is between the said island of New Orleans and the right bank of that river, as well as the passage both in and out of its mouth." Chalmers, Collection of Treaties, I. 46783; Martens, Recueil de Traités, I. 104-21. 
from contending that the British title to the West was itself founded on conquest. Indeed, this was a natural position for both herself and France to take, since in the Seven Years' War both had contested the British charter claims by force of arms, as France had previously done diplomatically. ${ }^{11}$ And with reference to the navigation of the Mississippi the position of the Spanish government was still more advantageous. 'The American argument was that the British right in this respect had devolved upon the United States in their capacity as proprietors of the former British holdings along the River. ${ }^{12}$ In other words, the American claim to this right depended at best upon the further clain, which Spain did not admit, of American proprietorship of the lands in question. But furthermore, the view that the British right to use the Mississippi within territory subject to Spain comprised a servitude for the benefit of all lands adjoining the Missis-

${ }^{11}$ An extended presentation of the French case is to be found in the Mémoire historique sur la Louisiane of 1802. See ch. I. 9-13 and note.

13 This was so, it was urged, both because the grant of right made His Britannic Majesty by article VII of the Treaty of 1763 was intended to run with the soil, was, in other words, an easement, and also because it was in accordance with the Law of Nature and of Nations, that the dwellers along the upper reaches of a river should have access to the sea through its lower reaches. See Journals of Continental Congress, XVIII. 942-3; also American State Papers, I. 250-3, where the argument is renewed by Jefferson as Secretary of State, 179?. 
sippi was rejected by Spain. The right which British subjects enjoyed to pass down the Mississippi through New Orleans and Louisiana, she contended forcefully, was a privilege granted by His Catholic Majesty solely to His Britannic Majesty and would therefore not be claimable by the United States even though they should make good their claims to territory touching the Mississippi to the northward. ${ }^{13}$

But the claim of the United States to extend to the Mississippi was also presented as the right of the American People. This argument rested upon the following propositions: first, that "the rights of the king of Great Britain to America were incident to his right of sovereignty over those of his subjects that settled America"; secondly, that, since with the Declaration of Indepen-

${ }^{13}$ See Vergennes' Instructions of July 18 and Sept. 25, 1779, to La Luzerne, infra; also Doniol, IV. 92. There can be little question that Spain's position in this controversy was the correct one at International Law. Thus, after considering the question "whether rights of navigation are possessed by states over rivers, or portions of rivers, not within their territory," in the light of the most important data, W. E. Hall concludes: "From the foregoing facts it appears... that where rivers flowing through more than one state are now open, they have usually at some time either been closed or their navigation has been subjected to restrictions or tolls of a kind implying that navigation by foreigners was not a right hut a privilege;... and that the opcning of a river, when it has taken place, having been effected either by convention or decree, has always been consistent with, and has sometimes itself formed, an assertion of the paramount right of property," International Law (5th ed., London, 1904), $139-40$. 
dence the right of sovereignty of the king of Great Britain over the people of America was forfeited, all rights founded in that sovereignty were forfeited with it; thirdly, that one such right was the right to the backlands of America. ${ }^{14}$ The

"Wharton, V. 85-9; Journals of the Continental Congress, XVIII. 936-7; Collections of the Nezo York Historical Society, 1878, pp. 138-9. The last citation gives the argument in the form in which it was presented on the floor of Congress, Aug. 16, 1782. Arthur Lee and Bland of Virginia at once attacked it vigorously. "Congress," said the former, "had no authority but what it derived from the states. The states individually were sovereign and independent, and upon them alone devolved the rights of the Crown within their respective territories." This was the position of the charter states. The position of the "landless states" was presented by Witherspoon of New Jersey, who first attacking the charter claims as mutually eontradictory and conflicting and altogether extravagant, proceeded: "The several states were known to the powers of Europe only as one nation under the style and title of the United States.... Whether the uncultivated wilderness on the frontiers should belong to one state or another was a matter of little concern to the European powers. The only argument that would weigh with them was whether it was necessary for the security of the United States that other natious should be excluded from that country, and particularly Great Britain, the enemy of these states." On August 27, a petition was reported to Congress from the inhabitants of kentucky, which, declaring that they considered themselves as "subjects of the United States and not of Virginia" and that "the charter under which Virginia claimed that country had been dissolved, asked Congress "to erect them into a separate and independent state and admit them into the federal Union," loc. cit., p. 146. Lee declared that the countenance that had been given the petition was "an insult to Virginia." Madison characterized "the supposition that the right of the crown devolved on the United States" as "so extravagant that it could not enter into the thoughts of any man," to which Witherspoon rejoined that it 
argument thus traversed the general opinion that it was not the American People but the American States that had succeeded to the sovereign rights of Great Britain, but by the same token it was the more accordant with the philosophy of the right of revolution, which is a right of populations and not of political units: and it also did justice to the claims of the "landless" states, of which Maryland was the unviclding champion. ${ }^{15}$ Diplomatically, too, it had the advantage of aroiding the difficulties that had their origin from the conflict of titles based on the colonial charters. On the other hand, plainly, it was adequate to establish the American title only as against powers that had recognized American independence, and Spain had not yet done this.

'The question of the abstract validity of the American claims in the West is, however, a matter, after all, of secondary importance both in our own interest and in fact. Our interest is in the policy of France, which in turn was shaped with reference to these claims quite indifferently to speculative considerations. 'To anticipate some-

evidently could, since it actually had entered into his own thoughts and also "the thoughts of the petitioners and into the thoughts of very many sensible men at the beginning of the present controversy," ib., 1.19. See also J. C. Welling in American IIistorical Association Papers, IIl. $167 \mathrm{ff}$.

${ }^{15}$ See H. 13. Adams, "Marylands Influence npon Land Cessions to the United States," Johns Ilopkins Universily Studies, III. pt. I. 
what the results of the inquiry to follow: So long as it was a question of pleasing the United States alone. France, having herself no territorial ambitions on the American continent, aceepted the Ameriean pretensions without demur. Later however arose, first, the problem of bringing Spain into the war and, secondly, the problem of securing peace with Great Britain, once that power was prepared to aceord the main objective of the war, namely American independence. Also, it was always a part of French calculations not to allow the United States to beeome too strong. The claims, therefore, that it had at first admitted, the French government came eventually to repudiate. Sereral questions are thus raised: 1. Could France act thus consistently with her engagements with the United States? 2. Was her repudiation supplemented by open championship of the interests of Spain along the Mississippi! 3. What light does her final attitude thrown upon the peace negotiations of 1782 ? In the pages to follow $I$ shall endeavor to answer these questions.

France's engagements with the United States touching the territorial possessions of the latter were defined by articles XI and XII of the 'Treaty of Alliance, which read as follows:

$\mathrm{XI}$ - The United States and France guarantee each to the other, the United States to His Most Christian Majesty his possessions in North Ameriea forever; His 
Most Christian Majesty to the United States their liberty, sovereignty, and independence, absolute and unlimited, as well in matters of government as of commerce, and also their possessions, and the additions or conquests that their Confederation may obtain during the war from any of the dominions now or heretofore possessed by Great Britain in North America, conformably to the 5 th and 6 th articles above written, the whole as their possessions shall be affixed and assured to the said states at the moment of the cessation of their present war with England. XII.-In order to fix more precisely the sense and application of the preceding article, the contracting parties declare that, in the case of a rupture between France and England, the reciprocal guaranty declared in the said article shall have its full force and effect the moment such war shall break out; and if such rupture shall not take place, the mutual obligations of the said guaranty shall not commence until the moment of the cessation of the present war between the United States and England shall have ascertained their possessions.

The first question that arises with reference to these articles is whether "the reciprocal guaranty" that by article XII was to be effective from the outbreak of the war between France and Great Britain extended to the possessions of the United States at that moment. The French government, after its change of position with reference to the pretensions of the United States in the West, contended that this guaranty extended only to the sovereignty and independence of the United States and that, with reference to the possessions and conquests of the United States, 
His Most Christian Majesty's guaranty was not to come into effect till these had been determined by the final treaty of peace. As to conquests there can of course be no doubt of the correctness of this view, for the reason that the subjectmatter of the guaranty would come into existence, if at all, only with the treaty of peace. The possessions of the United States, on the other hand, would at any particular. moment, what there were of them, be part and parcel of the United States-would, geographically speaking, comprise the United States. It was therefore not unreasonable, to say the least, for the American advocates to contend that the guaranty extended by the treaty to the sovereignty and independence of the United States, and admitted by France to be effective from the outbreak of war between France and Great;Britain, extended also, from the necessity of things, to the possessions of the United States. Furthermore, the guaranty in question is spoken of as reciprocal. But unless it extended to the possessions of the two powers it was not reciprocal, since it was only certain possessions of France that the United States guaranteed by any view of the treaty.

And such direct testimony as we have confirms this view of the matter. Thus, when the American envoys saw that they could not get an unconditional alliance and proposed, as a compromise, that the guaranty in the treaty of the indepen- 
dence and liberty of the United States should go into effect at once, Gérard, speaking in the name of the Foreign Office, repelled the suggestion by saying that the independence, liberty, and possessions of the United States must all stand on the same footing in this regard; that as to all alike the guaranty was contingent upon the outbreak of war. ${ }^{15^{3}}$ And the conclusion to be drawn from Vergennes' vehement protest against Florida Blanca's action in proposing the uti possidetis for the United States in April, 1779, is the same. This, the French secretary declared, menaced France's obligations to the United States at an essential point, which however was the case only on the assumption that France was already the guarantor of the territorial integrity of the United States. ${ }^{16}$

Yet suppose we admit, for the sake of the argument, that France did guarantee the possessions of the United States "against all other powers" only from the close of the war, to what extent are the engagements incurred by her in the Treaty of Alliance relaxed? Undoubtedly to the extent of relieving her from the necessity of continuing the war with Great Britain for such possessions, as distinguished from the sovereignty and independence of the United States. On the other hand, the concession does not relieve by one

\footnotetext{
15a Arthur Lee”s “Journal," Lee’s Lee, I. 388. For Gérard's later view, see Journals of the Continental Congress, XXIII. 518-9.

${ }^{16}$ See Doniol, III. 802.
} 
whit the ineongruity of active championship by France of the right of Spain, as part of the price of bringing that power into the war and keeping her there, to scive the possessions of the United States. In short, the question of the possibility of France's satisfying Spain along the Mississippi harmoniously with her engagements with the United States resolves itself into the question whether the 'Treaty of Alliance recognized the United States as holding territorial possessions in the Mississippi country, possessions from which, as it subsequently developed, Spain desired to exclude them.

'The fifth article of the Treaty of Alliance reads as follows:

If the United States shall think it fit to attempt the reduction of the British power remaining in the northcrn parts of America or the islands of Bermudas those countries or islands, in the case of success, shall be confederated with or dependent upon the said United States.

Here, as in article XI of the Articles of Confederation itself, was a provision looking to the possible aecession of Canada to the Americans, or to its conquest, and to one or the other of the even remoter islands of the Bermudas, but entire silence with reference to the region of vastly greater importance to the United States lying to the westward of the Mountains. ${ }^{17}$ 'The implica-

"This argument is from the Instructions of Oct. 17, 1780, to Jay, Journals of the continental Congress, XVIII. 911-2. It is as- 
tion could not possibly have escaped those who negotiated the 'Treaty of Alliance on the part of France, and especially since it had earlier been brought under their direct observation again and again. Thus in the outline of a treaty accompanying the instructions drawn up by Congress for "the American plenipotentiary destined for France," of September 17th, 1776, there appears a clear distinction between the portion of the continent thought to be involved by the Revolution and such outlying British dominions as Canada and the Floridas. ${ }^{18}$ Again, in the project of a treaty which Deane drew up for the French government this distinction gives way to a specific guaranty to the United States of the "possession of all that part of the continent of North America which by the last treaty of peace was ceded and confirmed to the crown of Great Britain."19 Somewhat later Deane also ap-

sumed throughout this document, which was largely the work of Madison, that the French guaranty of American possessions became operative with the Treaty of Alliance itself, that is, upon the outbreak of war between France and England.

${ }^{18}$ See art. IX of the Plan, Journals of the Continental Congress, V. 770 .

${ }^{10}$ Wharton, II. 215-6, and footnote. And of like implication are the following items. On the occasion of General Gates' celebration of the Fourth of July at White Plains in 1778, the following toast was offered: "May our brethren in Canada, Florida, and Nova Scotia speedily enjoy the blessings of free states." Connecticut Courant, July 14, 1778. The Pennsylvania Packet of April 6, 1779, contains a letter from an American gentleman in France, dated Dec. 8,1778 , in which the writer, after reporting 


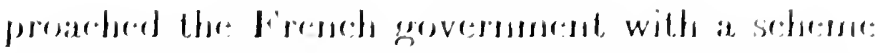
for oldanimer mones for the: United Sitates in France on the hasis of seceurity fumbished by west(an Jinds."

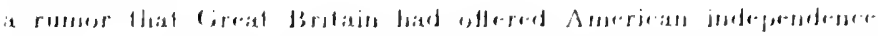

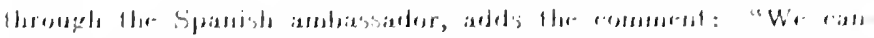

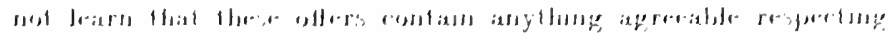

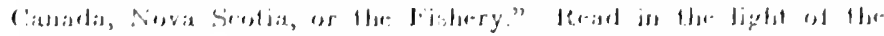

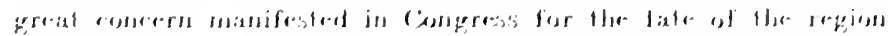

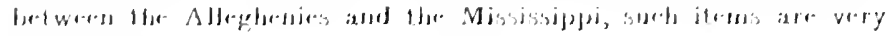
mblucher.

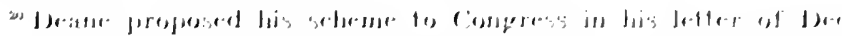

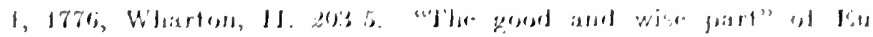

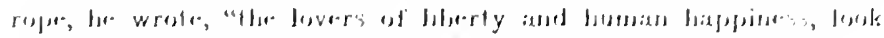

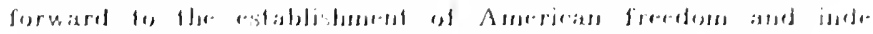

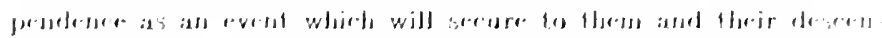

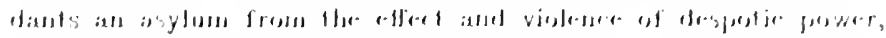

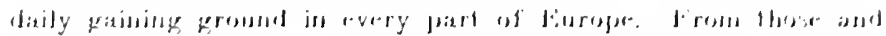

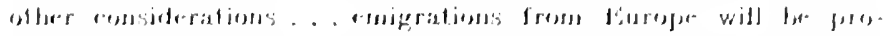

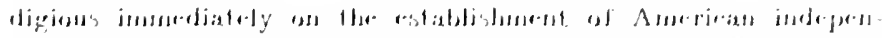

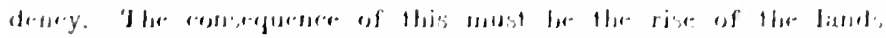

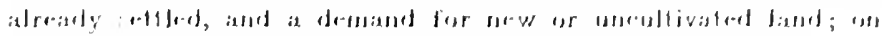

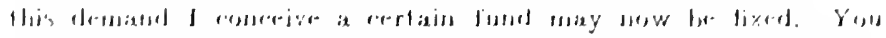

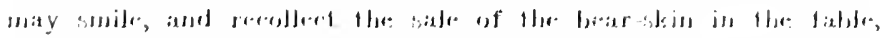

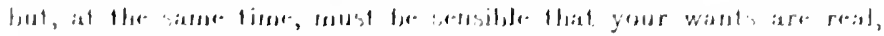

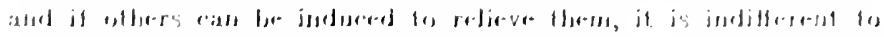

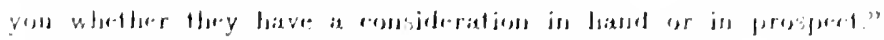

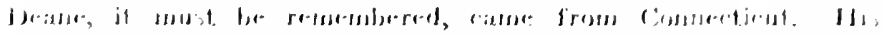

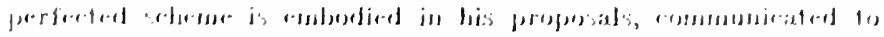

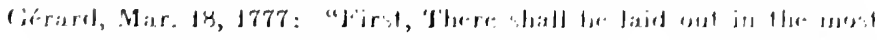

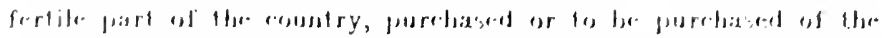

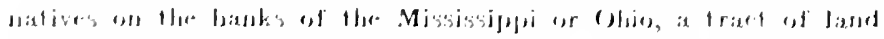

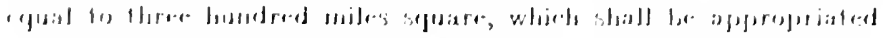

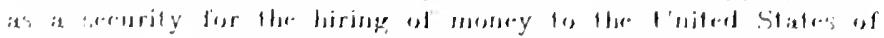

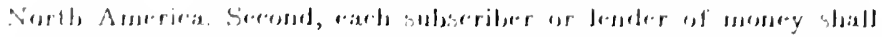

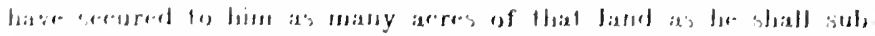

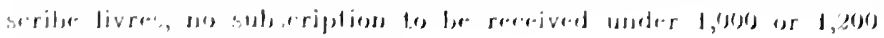
Jivre," ete. Sinsis., Nies o,tis. 
Certainly France was adequately informed of the pretensions of the United States respecting the West. Yet not only is there no record of her having demurred to these claims, but, on the contrary, the evidence clearly proves that both Bourbon governments at first recognized them as valid, as least so far as the territory between the Ohio, the Mississippi, the Alleghenies, and the somewhat variable northern boundary of the Floridas is concerned. So when, in the course of his interview with the American envoys on December 12th, 1777, Vergennes raised the point that Virginia's charter claims, by extending to the South Sea, tended to "trench on Spain's claims to California," and the Americans pointed to the fact that by the Treaty of 1763 a western limit had been set to the Colonies at the Mississippi and suggested that this line be drawn from the source of that river, "this," says Lee in his Journal, "was admitted as adjusting the matter properly." $0^{2}$ Again, what could have been more explicit than Florida Blanca's assertion in March, 1778, that the Mississippi comprised "a boundary sufficiently definite and visible" between the possessions of Spain and those of the United States? $?^{21}$ Indeed, it was exactly because he

2ara Lee's Lee, I. 361.

"Montmorin to Vergennes, Apr. 10, 1778, Doniol, III. 22. And in the same comnection note the implication of certain passages in Aranda's despatcles to Florida Blanca of Feb. 23 and Mar. 23, 1778. "I incline," he writes in the former, "to the opinion 
recognized this to be the case that the Spanish minister feared the United States to the degree that he did: the prescriptive rights of the United States, sanctioned as they were by France, made the situation irremediable. Vergemnes, on the other hand, it will be recalled, was at great pains to allay these fears, but even so, he did not assert that the Americans were intruders in the region between the Mountains and the Spanish domin-

that the great question with the [American] commissioners will be as to retaining Canada and Florida, and that the Congress will mike resistance, as it will not want the English for neighbors, but will wish to remain complete and absolute in all that part of North Imerica." Sparks MSS., CII. In the latter oceurs the following passage: "Still less will he [the king of Spain] displease the colonies after the signs of protection that he has given them, and being a new power which must come to be a formidahle one and upon which he is to border alone and which would never pardon such a turning of the back," etc. The important point is that Aranda here recognizes the United States to he at that date a power bordering on Spanish dominions. Note also the following words from his despatch of Aug. \& of the same year: "It seems to me that the intention of this Court cannot he to maintain that the new United States shomld charge thenselves with the rest of the Northern Provinces, hut that they should be linited to the thirteen confederated from the heginning." Thus the court of Iondon may "avoid the disgrace of losing the whole of the continent of America." The contrast, it will he ohserved, is between the thirteen enfederated Colonies and the northern ones. Another interesting dorument in the same comnection is Franklin's letter of Dec. 12, 1775, to Don Gabriel of Bourbou: " . . I think I see a powerful dominion growing up here, whose interest it will be to form a close and firm alliance with spain (their territories bordering)." complete Works of Benjamin Franklin, V. 548. Don Gabriel, therefore, was informed of Americas pretensions in the West from the first. 
ions On the contrary, he made the very distinction that was common with Americans, between the parts of America in revolt and such outlying regions as the Floridas and Canada; he cited "the vast expanse" of the existing dominion of the United States to prove that it would be ages before America would care for further accessions of territory; and he contrasted the Americans as "peaceable, unambitious neighbors," with the "avaricious, implacable" British. ${ }^{22}$ But the Spanish minister, unconvinced by the reasoning of the French secretary, at last came to the decision that it would be necessary for Spain to take the law into her own hands and expel the Americans from the banks of the Mississippi. He did not suggest, however, that the matter was one to be treated of with France, though the conquest of the Floridas, involving American interests but not American rights, was such a subject. And eventually the Treaty of Aranjuez was signed. Spain's apprehension of the United States had by this time reached its climax, as had also the anxiety of France to bring Spain into the war. Yet on the question of the western limits of the United States the treaty maintained complete silence.

${ }^{22}$ Doniol, II. 785; III. 51, 561. The argument, however, from the distinction made between colonies in revolt, on the one hand, and Canada and the Floridas, on the other, should not, in the case of Vergennes, be pressed too rigorously, since it does not clearly appear whether he regarded Canada as including Quebec as organized under the Act of 1774, though his recognition of Virginia's charter claims would tend to indicate that he did not. 


\section{CHAP'TER XI}

SIEUR GERARD AND THE CONTINENTAL CONGRESS

The views finally adopted by the Spanish government with reference to the Mississippi question apparently originated on this side of the Atlantic in the fertile brain of an Havana merchant, one $\mathrm{J}_{\text {uan de Miralles, who having been }}$ forced by mishap to put into Charleston early in 1778 in the course of a voyage to Cadiz, later received a commission from the eaptain-general of Cuba to act as a sort of observer of affairs in the United States for His Catholic Majesty. ${ }^{1}$

${ }^{1}$ According to his letter of Feb. 13, 1778, to Galvez, Miralles had set out from Havana for Cadiz the previous Dec. 31, hut had been forced by a leakage of the vessel bearing him to put into Charleston, Jan. 9. He had remained there since the latter date because of an interdict upon the departure of vessels from the harbor, due to the presence outside of a British blockading squadron, which had shown itself very unscrupulous in seizing neutral vessels. He intended to sojourn at Charleston till a favorable opportunity offered itself to continue his journey or to return to Havana. Meantime, he asked letters to Washington, Laurens, ot al. Ilis purpose in visiting Cadiz was to secure the monopoly of carrying uegroes to Havana, the right of the existing monopolists being about to lapse. He would like to institute such at eommerce from the Southern American states. Would Galvez urge his claims upon the king? As we have already seen, Florida Blanea had announced in September, 17r8, that Spain then had, 
"A typical Spaniard, infinitely zealous and wellinformed in the interests of his court in this part of the world," Miralles came to Philadelphia with the idea that France should conquer Canada and that Spain should conquer "all that the English had acquired by the Treaty of $\mathbf{1 7 6 3}$ in Florida and on the Mississippi"; but especially did he "give himself over to all the speculations which the possession of the Floridas and the exclusive navigation of the Mississippi could suggest." And the basis of these speculations was the conviction that sooner or later, the Americans were bound to become the enemies of Spain; that, indeed, this contingency was no remote one. ${ }^{2}$

Miralles' first care was to put himself in close relations with M. Gérard, who seems to have regarded his views, so far as they touched the interests of Spain, with entire complacency. Thus in his despatch of July 25, 1778, to Vergennes, heralding Miralles' appearance at Philadelphia, Gérard wrote:

I have persuaded him to report to his court that Congress would never consent from mere generosity to renounce the navigation of the Mississippi [which is]

or would presently have an agent in America to observe developments. I infer that the actual business of despatching such an agent was left to Galvez, who, seeing the opportunity offered by Miralles' accidental presence at Charleston, commissioned him to act in this eapacity. The letter just paraphrased is to be found in the sparks MSS., XCVII. Miralles did not appear in Philadelphia till July, 1778.

Gérard to Vergennes, July 25,1778 , Doniol, III. 293-4. 
necessary to serve as an outlet for the immense settlements which the Americans are proposing to make along the Ohio and other rivers tributary to it; that the expedition commenced by Major Willing in those parts was about to be followed up; that it had been suggested that Pensacola be offered Spain, while what the English hold on the left bank of the Mississippi be retained; that it appeared to me important that His Catholic Majesty should calculate upon this difficulty in advance; that the only means of obviating it, as it seemed to me, was not to put it in the way of the Americans to formulate demands in regard to the matter, that is to sily, to dispense with their aid, indeed to forestall it, by seizing these lands with Spanish forces alone.

\section{"Don Juan," Gérard concluded, "feels that my observations are correct and has promised me to render an account of them.".3}

"Lor. cit. See also Miralles to Galvez, Aug. 20, 1778, Sparks MSS. Here Miralles speaks of a plan communicated to him by Patrick Henry, then governor of Virginia for an expedition agrainst St. Augustine, the ultimate objective of which was to he the conquest of the provinces of Mobile, Mississiplui, Pensacola, and Florida. The original author of the plan, which called for the assemblage of three thousand men at Savannah, was the Marquis de Brétigny, with whom and the president of Congress Miralles discussed it at length. The latter treated the matter rather lightly: it was good enough to kill time with over a bottle of wine. None the less, Brétigny laid the plan before Congress in French and reported that this body had sent it to the interpreter. Miralles expresses the opinion that the conquest will be easy, but fears that American coijperation will give rise to pretexts "injurions to the dominions of the king. I say," he continues, "the same as to the conquest of Pensacola, Mobile, Mississippi, and the other countries on the Mississippi river," etc., "because if the neighbors assist in the conquest they will surely" claim the use and free passage of this river,... so as to pass 
But presently we find Gérard going far beyond this tone of disinterested criticism and becoming the avowed champion of the cause represented by the Spanish agent. For this there were several reasons: To begin with, diplomacy, unlike the law, recognizes no such category of questions as res adjudicatae. Again, as I have already pointed out, it was the most natural thing in the world for a Frenchman to take the position that England's title to the lands along the Mississippi was founded on conquest alone and was, therefore, open to conquest by an enemy. Yet again, Gérard was well aware of the anxiety of his government to meet the views of Spain at all possible

out to the Gulf of Mexico. It cannot but be apparent to the least informed person ... how prejudicial this would be." Brétigny's plan was reported to Congress adversely by the Board of War, Oct. 31, 1778, Journals of the Continental Congress, XII. 1083 ; but was again brought before that body by a letter from Miralles Nov. 24, 1779, ib., XV. 1301. This time the plan had the backing of the diplomatic La Luzerne and was also aided by the growing seriousness of the military situation in the South. On Dec. 16, accordingly, it was resolved "that General Lincoln ... be ... empowered...t . ... concert with the Governor of Havana, or any other person or persons properly authorized by His Catholic Majesty, such plan as shall in his opinion be best calculated to insure the reduction of the enemy's force in the state of Georgia ... and for the conquest of East Florida." North Carolina voted "nay," and Georgia was not present. Ib., 1388-9. More specifically, Congress' expectations were, that Spain would furnish six vessels of the line and five thousand troops, that Georgia would first be recovered, and that then the joint expedition would turn to Florida. The plan fell through when Lincoln was forced to surrender at Charleston. 
points and, in fact, was under specific instructions to forward these vicws in scveral respects. Finally, Gérard had little understanding of, or sympathy for the American point of view as represented in Congress. ${ }^{4}$

'This body, changing in membership and complexion of opinion from day to day, voicing a variety of local interests and personal animosities, deferring strangely, now to the views of popular committees, now to the pretensions of thirteen petty sovereignties, foll quite without the cut and dried categories of the French representative's experience as a diplomat and bureaucrat. Unfortunately, it was this fact precisely that M. Gérard most fatally failed to recognize. Following his controversy with Congress over the subject of a separate peace, it is apparent that Gérard pictured that body to himself as a species of landtag or diet of the sort that France in the casc of her client states on the Continent sought to dominate by division. In the case of the

'A characterization of Gérard by Stormont occurs in the latter"s despatch of Aug. 21, 1776: "M. Gérard is the most likely person for M. de Vergennes to employ [in dealing with Deane], and he could employ no man who would undertake such a commission with more ałacrity. I have known him long. Ne has parts, address, and no small share of artifice. He was much trusted at Vienna by $\mathbf{M}$. de Chatelet, and he has the same spirit of intrigue, the same desperate policy, the same jealousy and implacable hatred of Great Britain." SMSS., No. 1350. It was partly this talent for intrigue that involved Gérard in difficulties with Congress. 
Swedish Diet, for instance, it had been the "Hats" and the "Caps," the one the party of France," the other of Russia. So in the case of Congress it was "the Patriots," "the Friends of the Alliance," "the Friends of Peace," on the one hand, "the Swelled Heads" ("Têtes Exaltées"), "the Anti-Gallicans," "the Anglicans" on the other. That the latter and its leaders, Richard Henry Lee and Samuel Adams, contemplated treason to the alliance at the first opportunity, Gérard had little doubt; and as the same faction stood for the American claims in the West, it followed inevitably that those claims must be spurious."

It is to be noted, however, that Gérard was shrewd enough to begin his proselyting in Spain's behalf with the representative of a state that had only a very moderate interest in the land question, Gouverneur Morris of New York. To Morris he urged the necessity of Congress' reassuring Spain and suggested, to that end, that

${ }^{5}$ Aside from an interesting but quite inadequate article by John Fiske in the Atlantic Monthly, LXIV. $220 \mathrm{ffg}$., the subject of parties in the Continental Congress has received little attention in proportion to its importance. Some of the documents in the SMSS. are interesting in this connection; see Nos. 487, 729, 733 . 737, 1616. There is also much scattered material to be gleaned from the press of the date; see, for instance, the Pennsylvania Packet of 11ay 20, 1778, and Rirington's Gazette (Loyalist, N. Y. City), of Mar. 8, 1780. Still more valuable are the despatches of Gérard and La Icuzerne; see the Index to Doniol, under "Congrès," "Gérard," "I La Luzerne." 
St. Augustine, Pensacola, and Mobile, and the exclusive navigation of the Mississippi be guaranteed her. 'The American replied, in characteristic rein, that he appreciated the necessity of setting limits to the Confederacy, and particularly to the South, since he was thoroughly persuaded that the virtues required by a republic were to be bred only in a hardy elimate. Indeed, he himself thought that to hand over the navigation of the Mississippi to Spain from the mouth of the Ohio would be aecordant with the best interests of the United States, inasmuch as it was the only measure calculated to keep the growing population between the Ohio, the St. Lawrence, and the Mississippi dependent on the republic. At the same time he was aware that many members of Congress regarded this as a privilege which appertained to the United States of right and that, furthermore, there were powerful private interests enlisted in maintaining this right."

Forearmed with this not unfriendly warning, Gérard began a couple of months later approaching groups of delegates with vague insinuations bearing more or less remotely on the matter he had at heart. On December 22d he gave a dinner to which Miralles and several Congressmen were invited, in honor of Jay, who had just been

\footnotetext{
"Gérard to Vergennes, Oct. 20, 17\%-, Doniol, II. 73-3. As to the private interests involved, see Wharton, III. 135.
} 
elected president of Congress. Sitting "la pipe à la bouche," the participants spent several hours canvassing the subject of what sort of principles ought to govern the new republic in relation to other powers. Gérard admonished his hearers that all Europe suspected the American people of having inherited the aggressive and turbulent spirit of their ancestors and deduced the necessity they were under of proving the contrary. Fortunately they had an opportunity to evidence their love of justice by drawing "a permanent line of separation between the Spanish possessions and their own." A formal proposition to Spain, even though it were rejected, could but do them credit in the eyes of the world, by demonstrating their willingness to renounce both for themselves and posterity all ambition for conquest. His hearers acknowledged the wisdom of his remarks but protested that the American Constitution was incompatible with the spirit of conquest, notwithstanding which they felt confident that Congress "would furnish all the additional assurances that lay within its power." Gérard ought at this point, one would think, have brought forward the question of the navigation of the Mississippi. In point of fact, he kept discreetly silent on that topic. "It is," he wrote Vergennes, "a matter to be handled with secrecy and dexterity," for there existed in Con- 
gress, he had found, "the materials of a powerful party" opposed to Spain's interests.

However, Gérard did not long continue in this balancing posture. As usual, Congress was at this date in great financial straits. The idea accordingly suggested itself to the French and Spanish representatives that that body might be induced to sell Spain its "recent conquests in Louisiana and the Illinois country"; and in a series of conferences held at Miralles' and Gérard's dwellings, this suggestion was broached to Jay and certain of his associates. How far negotiations actually proceeded on this basis cannot,

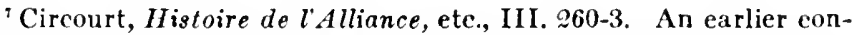
ference of similar purport is more briefly reported in Gérard's despatch of Dec. 12, Doniol, IV. 64-5. These conferences were followed by one with Washington, which is recounted in the despatch of Dec. 30: J'ai observé que l'Angleterre auroit vraisemblablement la plus grande répugnance à céder aux EtatsInis des territoires qui ne font point partie intégrante des Colonies . . . que les Etats, n'ayant à cet égard qu'un simple droit de conquête, ne doivent naturellement pas s'attendre que leurs alliés faissent la guerre un jour de plus pour leur procurer un aggrandissement étranger aux principes fondamentaux du systìme de notre union, acquisition désagréée et pleine d'inconviens pour l'Espagne. On a paru sentir vivement la force de cette réflexion, et j'espère que cela contribuera à déterminer les offres à faire à eette Couronne. M. Washington mayant demandé quelle compensation le roy demanderoit si ses forces concourraient à Ia conquête du Canada, ma réponse a été que je l'ignorois, mais que j'étois convaincu qu'elle seroit analogue à lettre et à l'esprit du traité d'alliance." Apparently, while Gérard, in speaking of territory that "formed no integral part of the colonies" had the Mississippi country in mind, Washington thought he was referring to Canada. Ib., 33. 
unfortunately, be determined, as the published Journals of Congress are silent on the subject, but according to a letter of Miralles, written late in January, Congress had appointed a committee of one member from each state to consider his proposals, and he had been informed by a member that favorable action was all but imminent. Indeed, according to a report of later date, Miralles had named the enormous sum of two hundred million lives as the amount that Spain would be willing to pay for the territory she desired, an offer which, had it been made definite, should have been quite irresistible. ${ }^{8}$

Be.that as it may, Gérard now began taking the frankest possible tone in discussing the conflict of interests between Spain and the United States in the West. "I stated," says he, reporting a conference that occurred late in January with a committee of Congress,

that the United States had no sort of right to the possessions of the English monarch which would not appertain equally to the king of Spain whenever he should becone engaged in war with England; that their right was restricted to the territory which they possessed as English colonies; that in admitting the demand of isolated and scattered establishments, they contradicted the principles of justice and equity which had directed the Revolution...; that ... the king

${ }^{8}$ For the matter of this paragraph, see Miralles to Galvez, Dec. 28, 1778, and Jan. 22 and 29,1779 ; also Rendon to Galvez, May 10, 1780, Sparks MSS., XCVII. 
would never prolong the war a single day to procure for them the possessions they coveted; that such benefits were absolutely foreign to the principles of the alliance and especially to the policy of the United states toward Spain, as well as the interests of that power; that good foeling would never be established with Spain so long as she had so great reason for distrust."

In a word, Gérard conveyed the idea that, if his government had ever accepted American pretensions in the West, it did so no longer. In this, however, he was altogether, and probably deliberately, misleading. For it is quite evident that the Foreign Otfice followed in the wake of its plenipotentiary's opinions in this matter rather than rice zersia; and at this date, the Office was still unaware that these had changed.

Farly in February Vergennes' despatch of the previous October arrived at Philadelphia, announcing that France had accepted Spain's offer of mediation and urging that Congress proceed at once to formulate the conditions upon which it would consent to peace. 'The document gives every evidence that the secretary still regarded the United States as the rightful proprietors of the region west of the Alleghenies. Thus speaking of the disposition to be made in the treaty of peace of Canada, Nova Scotia, the Floridas, and the Newfoundland fisheries, it says:

Gérard to Vergennes, Jan. 28, 1779, Circourt, op. cit., III. $264-6$. 
It would be of advantage, Monsieur, that Congress' ultimatum should include, first, the renunciation of Canada and Nova Scotia, or at least of Canada and the fisheries along the coasts of Newfoundland; secondly, the abandonment in favor of Spain of the Floridas, or of such parts of these colonies as shall meet the favorable acceptance of Spain.

In other words, the distinction between the British colonies in revolt and such outlying regions as the Floridas and Canada still underlies the secretary's thinking about the territorial question; and, as we have already seen, the quite inevitable deduction from this distinction is recognition of the extension of the United States, at least between the Ohio river and the somewhat indefinite northern boundary of West Florida, to the Mississippi.

And of like implication are the secretary's words on the question of the navigation of the Mississippi :

I do not know [he wrote] and I am unable to previse the intentions of the court of Madrid on this subject. But I judge from the situation of places that the Americans will insist upon the liberty of navigating the Mississippi for the settlements which they propose to establish along the Ohio, and I assure you that it would appear astonishing to me should anyone attempt to refuse them this demand. However, there may be some considerations of a local nature that I am ignorant of on the other side of the question, considerations meriting attention. You are in position to obtain the requisite information whether from the Americans themselves 
or from M. Miralles; and if they appear to be of such a character as to justify the refusal of Spain, you ought to prepare the Americans for it with prudence and mianagement. But in the contrary case, you ought to prevail upon the Spanish agent, not only to avoid charging his court with prepossessions on the subject, but also to lay the matter before it in such fashion that it will find no difficulty in according the Americans the consent which they will not fail to demand of it. ${ }^{10}$

Two weeks later, Gérard addressed Congress as a body on the subject of peace terms. Speaking of the necessity of meeting "the convenience of Spain," he was challenged to explain what he meant:

I answered [he writes] that His Catholic Majesty is too great and generous to desire an acquisition of territory ... , that it was the security of his frontier and the prevention of trouble with his neighbors that gave him his only concern ... , that the possession of Pensacola and the exclusive navigation of the Mississippi could alone fulfil this object. ${ }^{11}$

At this date Congress was still hopeful of a recognition from $\mathrm{His}$ Catholic Majesty, a hope which Miralles did not scruple to foster by disseminating misleading rumors. $^{12}$ In general

${ }^{10}$ Doniol, III. 569-70.

"Gérard to Vergennes, Feb. 17, 1779, Doniol, IV. 110-4.

${ }^{12}$ See ib., III. 294. The earliest word to reach America of the alliance represented Spain as party to it, SMSS., 821. The Continental Journal and Weekly Advertiser (Boston) of June 18, 1778 , eontained the following item from a London correspondent: "We can now assure the public that on Saturday a rescript was delivered from the court of Spain recognizing the independence of America." 
terms, therefore, Congress was quite willing to declare its intention of meeting Spain's desires. Nevertheless, it was speedily made clear to Gérard by delegates from Virginia and North Carolina, that the navigation of the Mississippi was not a matter admitting of unlimited concession. The West, said they, was filled up with adventurers, fugitives from justice, bandits; this was not by the desire of the states, but it was a fact; the way to civilize these people was to tie them up with industry and property, for which access to the sea by way of the Mississippi was essential to them; that Spain should continue to hold the key to that river, and even to strengthen her control by the acquisition of the Floridas was all right; but at least she must accord the West a port of entry at its mouth and, preferably, a Mediterranean port as well; such a policy would be a boon to Spain's own commerce. ${ }^{13}$ Gérard, though obviously impressed by these representations, hastened to disavow any special knowledge of Spain's commercial system; and meantime the matter of concession to Spain was becoming involved with other issues. With the general question of peace terms before it, Congress proceeded to develop principles meant to obtain for the United States as much as possible in all directions, the principle, for example, that the United States was entitled to independence plus all that ${ }^{13}$ Gérard to Vergennes, Feb. 18, ib., IV. 114-5. 
had incontestably belonged to the British provinces at the moment of the outbreak of the Revolution; that the very notion of independence implied the possession of Nova Scotia; and so onn ${ }^{1+4}$ Noting the trend of opinion, the plenipotentiary brought forward the suggestion that the fixation of boumdaries be deferred till the negotiation of peace,- a suggestion designed to give the mediating power a chance to make its voice heard. 'The idea, he regretfully admits, found no partisans. ${ }^{15}$

In fact, Gérard was soon to discover that his troubles had only begun. From his first reception of the news of mediation he had urged that Congress should hasten its work. In the middle of March, however, that body began a four months' wrangle over the question whether the United States should refuse any peace by which Great Britain did not accord them the privilege they had enjoyed as her provinces of participating in the Newfoundland fisheries. 'The interest back of this proposition was a local one, but vital to the locality concerned. ${ }^{16}$ It was also ably

1t The father of this species of dialectic was Samuel Adams, $i b$, s.3, footnote 1 , and 93, footnote 1 .

${ }^{15} \mathrm{Ib}, 92$.

16 For some contemporary newspaper discussion of the propriety of making the right to fish off the Grand Banks a sine qua non of peace and of delaying Congress' decision in the matter of peace terms for the benefit of New England, see the Penmsylrania Erening Post of early July, 1779, and the Pennsyluania Gazefte of Jume 23. Of especial interest in this eonnection is a manu- 
represented and soon had a powerful party at its behest. And not only was the French government's program of facilitating peace put in jeopardy by the proposal to make the fisheries a sine qua non condition, but the privilege sought could by no stretch of the terms of the Treaty of Alliance be brought within its purview. Gérard's blood was aroused as it had not been before, and this time at least, it is impossible not to accord him a measure of sympathy. "I told them," he records in his report of May 14th, "that $I$ was convinced that England would grant them the fisheries by the same title as that by which they had previously held them, to wit, as subjects of the British crown, but that they had no need of the aid of France for that arrangement." ${ }^{17}$ At this date he thought he had a considerable ma-

script in the office of the secretary of state of North Carolina, unsigned and undated; but in the hand of Thomas Burke, a North Carolina member of the Continental Congress at this period. The document, for a transcript of which I am endebted to Mr. Waldo $T$. Leland of Washington, comprises an account of the proceedings in Congress from March to $J$ uly, 1779 , relative to peace terms. Burke expresses sympathy for New England's interest in the fisheries but condemns the New England leaders for the lengths to which they pushed their claims. "Their claims," he writes, "extended so far as to interfere with the rights which must by the Law of Nations belong to Britain after the war ... and such rights as Britain is always jealous of in so high a degree that she would make war at any time to prevent encroachments on them." It is to be noted that Burke does not regard the territorial question as having caused delay.

${ }^{17}$ Doniol, IV. 138. 
jority of the delegates with him but a month later he had to confess that "the Party of Peace" was in a serious predicament, due largely, he charges, to the hostile influence of 'Thomas Jefferson. ${ }^{1 "}$ The crisis eame the middle of July, when Jay and "two other well-intentioned delegates," "torn and battered by the fray" and foreseeing civil war if New England was longer opposed, advised the French representative that the game was up. In the interview that followed Gérard by turns pleaded with, threatened, and cajoled his interlocutors: France was a great power and would remain one even if Ameriea deserted the alliance, but that America, taking counsel of her sense of shame, would never do. The prospect, however dismaying, would never force the king "to submit his neck to the yoke they would fain impose upon him."

I added that some people appeared to entertain the wish of breaking down the relations of France with Spain, but that I believed myself able to predict that, if the Americans had the audacity to reduce His Majesty to the necessity of ehoosing between the two, his decision would not be in favor of the United States; and I saw with astonishment and grief that the guardians of America's welfare saw in public affairs only their own factional and local interests, as if the whole world would bow down before their eapricious and changeable resolutions, confined within the circle of their own advantage, ... that certainly the king would not con-

${ }^{18} / 6 ., 135 \mathrm{ff} g ., 153-5,165-7,174-5$, ete. 
sent to consume the rest of his realm through a succession of years in order to procure a small increase of fortune for a few New England shipowners. ${ }^{19}$

'These rigorous representations met with a degree of success. For in the instructions finally voted by Congress on August 14th the claim to a share in the Newfoundland fisheries was, so far as the anticipated treaty of peace was concerned, left to the chances of negotiation and its recognition made a sine qua non condition only of the commercial treaty with England which it was expected would follow the conclusion of hostilities. $^{20}$ But in doing this much, Gérard had done his utmost. 'The making a commercial treaty with England dependent upon American participation in the fisheries was to the prejudice of the tobacco states, whose further interests in the West, accordingly, Congress was less disposed than ever to sacrifice. By the same instructions of August 14th, the western boundary of the United States northward of $31^{\circ}$ north latitude was asserted to be the Mississippi, and the recognition by Great Britain of this boundary was made an ultimatum. ${ }^{21}$ A month later further

${ }^{19}$ Gérard to Vergennes, July 14, ib., 177-81; see also, same to same, July 18, ib., 219-\$3, where the plenipotentiary vigorously attacks the selfishness of individual states.

${ }^{20}$ Journals of the Continental Congress, XIV. 960-1. However, a treaty of commerce could have heen entered into by the "unanimous consent" of the states, without Great Britains" having met the sine qua non.

${ }^{21}$ Ib., 958-9. 
resolutions were adopted proffering the assent of the United States to His Catholic Majesty's conquest of the Floridas, on condition that he accede to the treaties between the United States and France, and "provided always, that the United States shall enjoy the free navigation of the river Mississippi into and from the sea." Also, the American negotiator was "particularly to endeavor to obtain" for Americans, their vessels and merchandise, a free port or ports south of the thirty-first parallel."2

On October th, John Adams, a reliable champion of New England's interests, was appointed the representative of the United States for the purpose of negotiating peace and John .Jay, whose attitude on the boundary question was at this date somewhat ambiguous, American representative at Madrid. ${ }^{23}$ Meantime, Gérard, broken in health and awaiting the arrival of his

2 Jourmals, XY. I0st, under date of Sept. 1\%. On Oct. 13, Witherspon of New Jersey, seconded hy Governeur Morris of New York, moved that "the claim of a free navigation of the Mi-si-sippi" be receded from if the obtaining of it "loe found an imsuperable bar to the proposed treaties of anity and commerce hetween these states and His Catholic Majesty," ib., 1168. The motion was roted down. Its nltimate trimmpl is diseussed infira.

211., 1112-3. The result was arrived at, atter a long contest, by a combination of Jay's and Aclams' frichds. See ib., 110 a and 1113. It shoukd be noted that Adams known bias supplied the deficiency of his instructions with reference to the fisleries, while Jays instructions on the Mississippi question made his personal opinion a matter of indifference. 
successor with impatience, had become thor. oughly disgusted with Congress. "The only way to save America from her madness and despite herself," he wrote Vergennes, "would be for the king to take advantage of the delay and conclude a peace along the general lines of the alliance." 24 The appointment of $\mathbf{J}$ ay afforded him a measure of consolation at the moment of his withdrawal from America, but even that was far from concealing his practical defeat. ${ }^{25}$

2 Despatch of July 31, Doniol, IV. 201.

${ }^{25}$ See $i b ., 211$. For the exchange of compliments between Gérard and Congress that attended the former's leave-taking, see Journals, XV. 1072-4, 1085. 


\section{CHAP'TER XII}

THE MISSION OF LA LUZERNE

Compared with that of his predecessor, the mission of Louis XVI's second plenipotentiary to his republican allies was a pronounced suceess. In great part no doubt the circumstances of the war, as we shall see presently, made the Chevalier de La Luzerne's triumph inevitable, but this fact should not obscure to us that gentleman's own personal deserts in the least. Affable of address, good-natured, sensible, direct, bent on discovering and reporting the facts rather than a confirmation of his own views about things, experienced in meeting men on their own level, turning a discerr ing eye upon vulnerable points of character, and with a wholesome endowment of the spirit of laisse aller, La Luzerne acquired a personal ascendancy over Congress in matters touching the common cause of France and the United States that had never fallen to the lot of the acrid and pedantic Gérard, even in the honeymoon days of the alliance. His methods, it must be admitted, were not always unexceptionable, for if we are to believe his own accounts, he sought on oecasion 
to "accelerate public opinion" as expressed in Congress by well-placed douccurs, whereas Gérard seems to have done nothing more reprehensible than to subsidize pamphleteers and writers for the papers. On the whole, however, the Congresses that the later envoy had to deal with were of higher average character than some that had come earlier; and his greatest triumph, the voting of the Peace Instructions of June 15th, 1781, was brought about with the assent and assistance of men who would have scored bribes. ${ }^{1}$

"For a characterization by the Englishman Wraxall, see Wharton, I. \$81. (p. \$25). "The Count de La I uzerne," wrote Gouverneur Morris, "is an indolent, pleasant companion, a man of honor and obstinate as you please, but he has somewhat of the creed of General Gates, that the world does a great part of its own business without the aid of those who are at the hase of affairs," $i b$. For testimony to La Luzerne's services to the military estahlishment, see La Fayette to Vergennes, May 20, July 93, Oct. 4, 1780, and Fel. 1, 1781, SMSS., Nos. 1625, 1626, 1627, and 1633. La Fayette notes that La Luzerne pays no attention to the quarrels of private individuals and that he is held in the greatest esteem both in and out of Congress. Another item to the same effect is to be found in Rirington's Royal Gazette of May 3, 1780. In a letter of the previous month from a gentleman in Maryland to a correspondent in St. Eustatia, complaint is made that France has "gained an absolute aseendancy over the councils and government of the country." "M. Gérard . . laid the foundation of French influence. M. La Imzerne... has steadily pursued the same steps." He advised Congress to pass the act of Mar. 18, 1780, redeeming the Continental currency at the ratio of 40 to 1 . He "commands the majority of that body as much as the English ministry do that of the British Parlimment. He has told them that if they mean to govern this continent, they must keep the people poor. . . This, says he, is our maxim in France. . . Poor men 
At the ontset, however, La Luzerne was foreed to treat the situation before him more or less from the point of view of others, since his first instruetions, bearing the dates July 18 th and September 25th, 17 59 , were prepared by the French Foreign Office exelusively in the light of the information that had come from Gérard. We are not surprised, then, to find these despatches setting forth the following ideas: That there existed in Congress a party headed by the Lees and Adamses which, if it had not "already sold out to England," at any rate sought to establish principles diametrically opposed to the alliance; that this party stood for a separate negotiation with England to be followed by an alliance with that power, for the prolongation of the war for objectives outside the scope of the alliance, and for opposition to the interests of His Catholic Majesty; that since Spain was now a party to the war and thus a defender, at least indirectly, of American independence, it was the duty of Congress to satisfy that power in the matter of a fixed western boundary for the United States, the navigation of the Mississippi, and the con-

make the most obedient subjects and the best soldiers." For instances of Ia luzerne's intervention with Congress in behalf of greater military efficiency, see Wharton, $11 \mathrm{l}$. 653-5 and 803-5. Though he did nol mingle in the quarrets of individuals and factions, he did combat openly Arthur Lee's candidacy for the secretaryship of Foreign $A$ ffairs, in 1761, and with success, securing the selection of Rohert R. Livingston. See Doniol, IV. 597. 
quest of the Floridas; that the United States had no title to the lands adjoining the Mississippi, but that that region was still English and therefore subject to conquest by Spain, and that Spain ought to conquer it with a view to procuring "clear, exact, precise, and unchangeable" limits to the pretensions of the United States and especially "to forestalling the hopes of conquest to which the provinces of the South might give themselves over"; that the Americans probably never had any right to navigate the Mississippi, since "the boundaries of the British provinces did not extend to that river" and it would be absurd for them to claim the right on the score of England's title; that the Floridas did not appertain to the United States under any title, but that Spain had the greatest interest in repossessing herself of this colony, which was so necessary to insure her commerce on the Gulf of Mexico from outside disturbance; that the guaranty pledged by France to the United States by article XI of the 'Treaty of Alliance was definitive only as to their sovereignty and independence and would extend to their possessions only from the close of the war; that the French government was confirmed in its espousal of Spain's interests in North America by the consideration that it was itself without interest in seeing that continent "enjoy the rôle of a power or in seeing her in a position to give disquiet to her neighbors"; 
that, in other words, "the only purpose of our views with reference to the United States is that they shall be independent and peaceable."'2

La Luzerne received the despatch of July 18th on $J$ anuary $20 t h, 1780$, seven months after it was penned, and a few days later communicated its purport to Congress. At one point, however, he deviated conspicuously, if not from the letter, at least the spirit of his instructions. For while Vergennes' obvious intention had been that the whole influence of France should be brought to bear upon Congress in the interest of Spain, La Luzerne had been long enough on the ground to have discovered that this would never do. For the tone of advocating Spain's views he accordingly substituted that of impartially reporting them, with the result of implying that his own government's concern was limited to having brought to an end an unfortumate difference of opinion between its allies. But his discretion arailed him little. For one thing, the very fact that Spain was now in the war for her own objects prejudiced his efforts; for it was well argued that the principal reason for concession to Spain

The most material portions of these documents are given in Doniol, IV. 228-5 and 357-61. They are given complete in Circourt, op. cit., III. 266-84. Cf. Journals of the Continental Congress, XXIII. 518-9, where is quoted an argument of Gérird's, dated May 22,1779 , on the guaranty. This, says the envoy, "ne commercera qu'à l'époque à laquelle le; possessions des Etats-Unis auront été constatées par la cessation de la guerre." 
had been all along to make her a party to the war, whether as an ally of the United States or not, and that this reason was now at an end. Moreover, as it chanced, La Luzerne was also under the necessity at this juncture of disclosing to Congress the final terms on which Spain had offered mediation to Great Britain and Vergennes' objections thereto. Such candor; on the part of our ally, as well his opposition to the principle of the status quo, was of course most reassuring, but the effects of the communication upon Congress' attitude toward His Catholic Majesty was naturally bad. When therefore, La Luzerne reported, it was learned that the Spanish monarch claimed the right to conquer the lands to the east of the Mississippi, he found himself confronted with "reasons already very powerful" to which were now added "unfavorable dispositions," and his endeavors to rebut the American claims, he frankly owned, "made little impression." This was early in February. A month later the Philadelphia Gazette published an account by Miralles of recent Spanish successes along the Mississippi. The effect of this disclosure was, La Luzerne wrote his government, great public excitement and a universal disposition to assert the American title to this territory. Thus it was pointed out that several states had sold and were still selling lands in the regions involved; that adventurers from the states were planting the banners of their 
provinces there; that (ieorge Rogers Clatk hat, in behalf of his state Virginia, been waging war against the British posts in the Northwest for nearly two years. In his perplexity La Luzerne turned to Ciliralles, who astonished him by disclosing the fact for the first time that he possessed neither any direct authority from Madrid nor yet any certain knowledge of its intentions. Nevertheless, the arrival at this moment of the despateh of September 25th foreed the French representative to renew his efforts in Spain's behalf, which he did with the usnal measure both of discretion and effect. Even delegates whose friendship to the alliance could not be questioned expressed regret that Spain should thus seek to sow seed's of discord between herself and the United States. Some months later La Luzerne reported the following words of a Virginia delegate, with reference both to the land question and the question of the navigation of the Mississippi: "We should he endeavoring to deceive Spain if, in treating with her, we obligated ourselves to make a renumciation that the nature of things renders impossible." In the same report, La Luzerne also noted that the delegates from the Northern states, though without direct interest in the matter, generally sustained the pretensions of the Soutl."

\footnotetext{
${ }^{3}$ For this paragraph, sec Doniol, IV. 331- 7 paraphrasing reports from la luzerne between the dates Jan. 25 and Ang. 25 ,
} 
La Luzerne's candid, if somewhat discursive, reports furnished his government for the first time with anything like a true picture of Ameri-

1780. Some further items of the same purport are given in P. C. Phillips, The West in the Diplomacy of the American Revolution, pp. 150-84, passim. On Aug. 29, the Virginia delegates laid before Congress instructions from the legislature of their state reasserting Virginia's charter claims and the American right to navigate the Mississippi, Journals, XVII. 755; Papers of the Continental Congress, No. 71, I. fol. 391. This action on the part of Virginia led Congress, on Oct. 4, to instruct Jay to adhere to his former instructions on the navigation question, and on Oct. 17, to accept the before cited letter of Oct. 17, prepared by Madison to urge the American claims in the West at length, Journals, XVIII. 900-9 and 935-17. In the latter document attention is paid to the Spanish claim of a right by conquest to some of the western country. It is answered: " 1 . That these possessions are few in number and confined to small spots. 2. That a right founded on conquest . . cannot comprehend the circumjacent territory. 3. That if a right to the said territory depended on the conquests of the British posts within, the United States have already a more extensive claim to it than Spain can acquire, having by an important success of their arms obtained possession of all the most important posts and settlements on the Illinois and Wabash, rescued the inhabitants from British domination, and established civil government in its proper form over them. They have, moreover, established a post on a strong and commanding situation near the mouth of the Ohio; whereas Spain has a claim by conquest to no post above the northern bounds of West Florida except that of the Natchez, nor are there any other British posts below the mouth of the Ohio for their arms to be employed against. 4. That whatever extent ought to be ascribed to the right of conquest, it must be admitted to have limitations which in the present case exclude the pretensions of His Catholic Majesty. If the occupation by the king of Great Britain of posts within the limits of the United States, as defined by charters derived from the said king when constitutionally authorized to grant them, makes them lawful objects 
ean opinion on the Mississippi question. Furthermore, they arrived at Versailles at a time ealeulated to impart to their message considerable poignancy.

Throughout the greater part of 1780 and into the rear following, His Catholic Majesty, practically withdrawn from the war, was engaged in peace negotiations with an English emissary. That Spain intended actually to abandon her alliance with France, Vergennes professed not to believe. but he very justifiably feared that she again sought to impose the status quo on the United States. 'This, however, he wrote Mont-

of conquest to any power than the United States, it follows that every other part of the United States that now is, or may hereafter fall into the hands of the enemy, is equally an object of conquest. Not only New York, Long Island, and the other islands in its vicinity, but almost the entire states of South Carolina and Georgia might by the interposition of a foreign power at war with their enemy, be forever severed from the American confederaey and subjeeted to a foreign yoke." Madison was greatly assisted in this argument, as indeed were the American advocates generally, by the faet that at this period the today familiar rule of "effective oecupation" had no place in International I aw. See also the New York Gazette of July 15, 1780, where the writer ealls for the early "eonquest of the continent." Evidently, popular expectations in this matter still ran high.

- Vergennes to Montmorin, Mar. 31, Apr. 21 , June 12, June 30, July 6, and Sept. 28 , Doniol, IV. 450-1, 453, 467-84. It is not impossible that Vergennes took too charitable a view of the Spanish government's proceedings at this time. According to a recent account of Cumberland's mission, based on English sources, Florida Blanca offered, in return for Gibraltar, to withdraw from the war and "to pay besides in ships, treasure, and territory." On the British side, according to the same account, "four Cabinet coun- 
morin, would be to saleritice the homer of France, the substantial purpose of the ware and in the lomg muspainsown interest. 'l'he English and Americams, left in juxtaposition. would remite their foreses. Incited by the Finglish, the Amerieans would penetrate to the heart ot Mexieo, whose people they would encombere "to aspire to a sweeter sovernment." 'Then indered would spain have canse to f'alr the example of American independenee." 'These arements made as little impression mpon the Spanish momareh and his minister as they had two years before. Is late as the end of (jetober. with New York City, the Camolinas, and (reoregia now moler British eontrol. Florida Blanear openly defended the status quo for the E'nited Sitates."

"cils met on the hunines" and tinally formulated the English terms, which however were still more exorbitant. M. M. M. Marks,

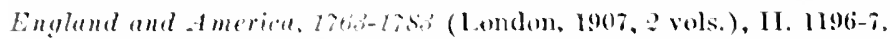

s)oniol, 12, 450-1, 153, and 1sio.

"16. f(19). Vergennes comments an kelorida blancas's attilude in

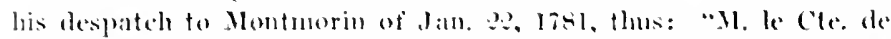
Floride Blanche eroit, M., gue nows herions fort heureux si mous parvenions à obtenir le state que, peur lamerique seple. Ca ministre na done pas jette les yeux sur la carbe de ceette partie do monde pour roir ce que a seroif quin pareit state quo daus le moment achuel: on bien il desespere entierement ale notre dause, ou

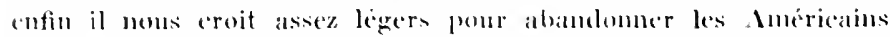
sans la neessite la plus urenente. La verite ent, M., que si le Roi stipuloit $l$ uli possidetis a l'egard des Etats-lnis, il les mettoit

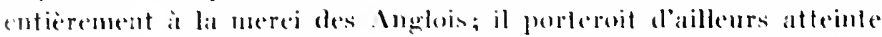
it sil reputalion; il autorineroit les lubrieams a la défeetion, vers latquelle la eour de londres dirige ensentiellement toule sil politique." 16. Slo. The statu que, in short, wombl represent the 


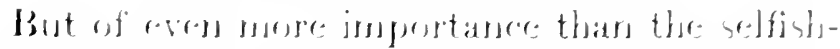

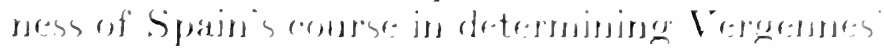
attitude at this time on the Mississippi questiren

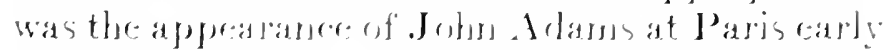

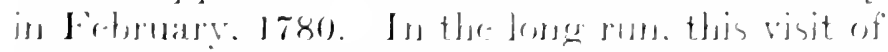

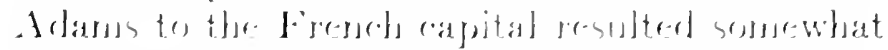

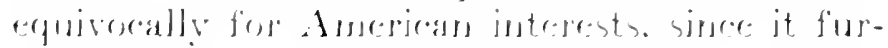

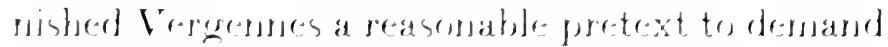
the comegessional Instruations of Jume l.jth,

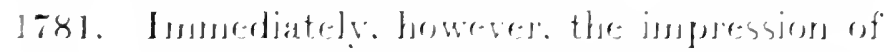

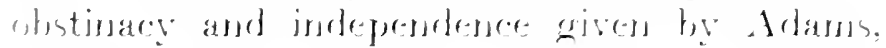

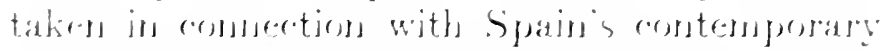

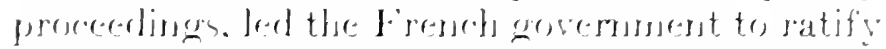

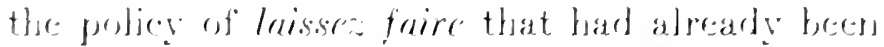

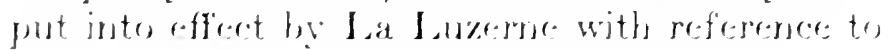
the matters at issiue between I rances allies.

Alams had hardly arpived in Paris than has stastled Vergenones with the sugerestion that hes

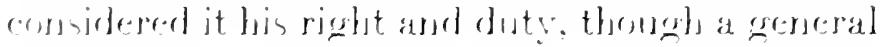

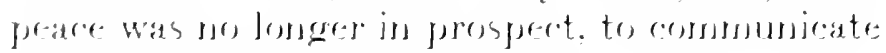

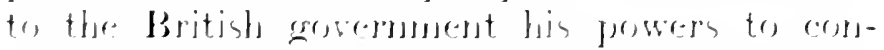

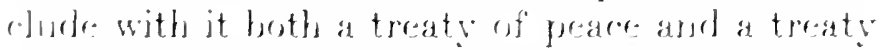

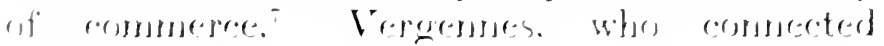
Arlans with that faction in (ioneress which, atc-

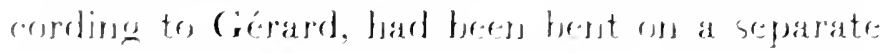

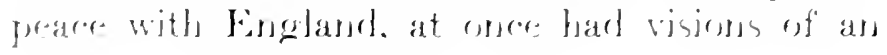

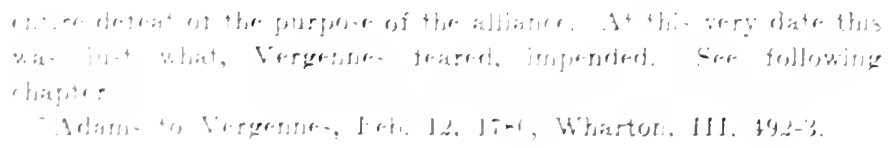


outcome to France's efforts in behalf of America that would have been ironical in the extreme. ${ }^{7^{2}}$

To'be solicitous about a treaty of commerce before peace is established [he wrote Adams] is like being busy about furnishing a house before the foundation is laid. In the situation in which America stands at present with regard to England, to announce to that power that they have forgotten her system of tyranny, her cruelties, and her past perfidy, is discovering too great a degree of weakness, or at least too much good nature, and inviting her to believe that the Americans have an irresistible predilection for her.... To propose a treaty of commerce, which must be founded on confidence and a union equivalent to an alliance, at a time when the war is raging in all its fury ... , what is it but to give credit to the opinion which all Europe entertains; . . . that the United States incline toward a defection, and that they will be faithful to their engagements with France only till such time as Great Britain shall furnish them a pretext for breaking them? ? $^{2}$

But Adams, quite obsessed with the idea that the time was ripe for an appeal to English public opinion in behalf of peace and the recognition of American independence, refused to be convinced by the French secretary's logic, though he eventually deferred to the latter's urgent request to postpone action on his opinion till further in-

ia See especially Vergennes to La Luzerne, June 3, Doniol, IV. 414.

" "Observations on Mr. J. Adams" Letter of July 17, 1780," Wharton, IV. 3-6. 
structions from Congress." But this was only after repeated argument on the subject, and meantime other irritating issues had arisen between the two men.

Thus in June the question came up of the justice of the "40 to 1" Act of March 18th, to foreign holders of Continental currency. Approached on the subjeet, Adams prepared what was an able defense of Congress' action, ${ }^{10}$ but to it added in conversation with agents of the Foreign Office, some rather unnecessary frills:

The course Congress had taken was wise, indeed very wise, just, very just; and those who complained of it were either English emissaries or spies ... [Moreover] the French had less reason for complaint than any body else . . . since were it not for America, to whom France should understand she was under the greatest obligation, England would be too powerful for the House of Bourbon, and Russia, Denmark, Sweden,

'Adams to Vergennes, July 26, ib, 7-11. Congress disapproved of Adams' efforts to communicate his powers to the British government. "Congress consider your correspondence with the Count de Vergennes on the subject of communieating your plenipotentiary powers to the ministry of Great Britain as flowing from your zeal and assiduity in the service of your country; hut I am directed to inform you that the opinion given you by that minister relative to the time and circumstances proper for communicating your powers and entering upon the execution of them is well founded. Congress have no expectations from the influcnce which the people of England may have on the British counsels. ..." I Iuntington, President of Congress, to Adams, Jan. 10, IFisl, Whartom, IV. 2æa.

io Adims to Vergennes, June 22, ib., III. 809-16. 
Portugal, and Holland would never be confederated against that power. ${ }^{11}$

A month later Adams wrote Vergennes, à propos the despatch of 'Ternay and Rochambeau's expedition, to urge that a French fleet be maintained somewhere along the American coast over winter, emphasizing especially the value to be derived from thus keeping the British line of supplies and communications constantly menaced. Certainly this was a sensible idea enough. Unfortunately, in pressing it upon the French government not only was Adams invading the province of Franklin, but he brought to his selfassumed task the most egregious lack of tact. "Iet the whole system of France be considered," he wrote, quoting from a current English circular, from the beginning down to the late retreat from $\mathrm{Sa-}$ vannal, and $I$ think it is impossible to put any other

${ }^{11}$ Doniol, IV. $416 \mathrm{fn}$. This was on June 17, but more than a month earlier Adams had written to Genêt to much the sanie effect: "To suppose that France is sick of the part she has taken is to suppose her sick of that conduct which has procured her more respect and consideration in Europe than any step she ever took. It is to suppose her sick of that system which enabled her to negotiate the peace between Russia and the Ottoman Porte, as well as the Peace of Teschen; that system which has enalsled her to unite in sentiment and affection all the maritime powerseven the United Provinces-in her favor and against England. It is to suppose her sick of that system which has broken off from her rival and natural enemy the most solid part of her strength; a strength that had become so terrible to France and would have heen so fatal to her." Adans to Genêt, May 9, 1780, Wharton, III. 667 . 
construction upon it but this, viz., that it has always been the deliberate intention and object of France, for purposes of her own, to encourge the continuation of the war in America in hopes of exhausting the strength and resources of this country [Englind] and of depressing the rising power of America.

'True, he himself disarowed harboring any such belief, but he strongly implied that, in view of the desultory fashion in which Franee had thus far waged war, it was by no means an unreasonable belief, and also, that it was one which was likely in time to gain a strong foothold in the United States. ${ }^{12}$

Vergemnes' response is clated a week later. It announeed that there was "every reason to behieve that they ['Ternay and Rochambeau] will take their station during next winter in North Anerica," and eontinued: "You will perceive, sir. by this detail, that the king is far from abandoning the eause of Ameriea and that His Majesty without having been solicited by Congress, has taken effectual measures to support the cause of Ameriea."13 Adams' spontaneous reaction to this intelligence was most enthusiastic. "I assure Your" Excelleney," he wrote the day following, "that scarcely any news I ever heard gave me more satisfaction." ${ }^{1+}$ But this was due to the fact that he had not given proper attention to the state-

\footnotetext{
${ }^{12} / 6 . .481-55$.

${ }^{11} / b ., 8 \div 0-1$.

16. $I 6,82$.
} 
ment in Vergennes' letter that His Majesty's action had not been solicited by Congress. In his letter of July 27 th to the secretary he proves at length that Congress had asked for just such aid as was at last being furnished, as early as $\mathbf{1 7 7 6}$, and had repeated the request several times since. ${ }^{15}$ 'This was the straw that broke the camel's back. Up to this time Vergennes seems to have kept his temper with the New Englander fairly well, but on July 29th he wrote him that henceforth His Majesty's government would confine its dealing in matters affecting the two allies to Dr. Franklin. ${ }^{16}$ A few days afterward Adams withdrew to Holland. ${ }^{17}$

But some time before this upshot of the matter, Vergennes had come to the conclusion that the standing of the alliance with the American Congress, whose chosen representative Adams evidently was, was too delicate to be further jeopardized by France's appearing in the thankless rôle of champion for Spanish interests where these conflicted with interests of the United States. In his despatch of June 3rd, 1780, to La Luzerne the French secretary reiterated his personal belief that Spain had the right to seize the lands to the east of the Mississippi if she could,

${ }^{15} \mathrm{Ib}$, IV. 12-4.

${ }^{16} \mathrm{Il}$., $16-7$.

${ }^{17}$ Here, too, his conduct was quite displeasing to Vergennes, loc. rit., 562-3; V. 48. 
that whatever might be the terms of the charters of the Southern states, the English were still the proprietors of these lands, and that there was, therefore, nothing to oblige Spain to hand over to the Americans such of them as she should conquer. But, he continued, that was not a matter for France to decide, wherefore La Luzerne should utter no opinion on the subject but should leave the whole question with Miralles. 'The French envoy should limit himself to advising influential members of Congress "not to use the language of right to the court of Madrid, but rather to appeal to its magnanimity." Finally, he added that he had confidential word to the effect that the Spanish government was strongly disposed to surrender to the Americans the east bank of the Mississippi above the Floridas and to accord them "some sort of navigation of the river." 1s And his despatch of August 7th was along sugstantially the same lines. The pretensions of Spain, said the minister, "are very delicate to treat of ; our intervention has not been asked for, and silence will be without disadvantage." La Luzerne should therefore merely avail himself of such occasions as chanced to offer "to bring Congress to have confidence in the Catholic

${ }^{18}$ Doniol, IV. 127-8. In a despatch to Montmorin, dated June 12 , Vergennes reiterates his interpretation of the guaranty elauses of the Treaty of Alliance: "I a garantie des domaines des EtatsUnis est éventuelle, son étendue ne sera déterminé que par la future pacification," ib, 459-60, footnote. 
king and to decide the question of the lands along the Mississippi without prejudice."19

Notwithstanding these despatches, in October, 1780, while La Luzerne was absent at Hartford attending a conference between the American and the French commanders on the military situation, his youthful secretary Marbois, at the instance of Rendon, the successor of Miralles, who was now dead, presented Congress an extended memoir showing, "with the greatest energy," "the absence of any foundation" for the American pretensions in the West and "giving them to understand that they need not expect the king of Spain to assent to them." "'o The following February 15th Congress did, in fact, decide upon a measure of concession to Spain, when it instructed $\mathbf{J}$ ay to recede from the demand for the right to navigate the Mississippi below $31^{\circ}$ north latitude and a free port there, "provided such cession shall be unalterably insisted upon by Spain."'1 But the

${ }^{13} \mathrm{Ib}, 429$.

${ }^{20}$ Rendon to Galvez, Oct. 20, 1780, Sparks MSS., XCVII ; Doniol, IV. 5934. Marbois was assisted in the preparation of this letter by Jenifer of Marylant, one of the leaders of the "landless" state faction, P. C. Phillips, op. cit., 182-3. Jenifer, then president of the Maryland senate, had stated his views at length to Gérard, early in July, 1779, Doniol, IV. 168-70.

${ }^{21}$ Journals, XIX. 152-4; Wharton, IV. 967-9. This resolution was in immediate consequence of instructions received by the delegates of Virginia, authorizing them to assent to the terms indicated in the interest of a "speedy conclusion of an alliance with Spain," Journals, loc. rit. 151. The motive underlying this resolution was distrust of the negotiations then going on in Spain. 
decision was due not to Marbois' representation of Spain's rights, which indeed was answered on the spot, but to the state of the war, and the question of the lands along the river was not affected by it. Four days later-but four months after Marbois' intervention-Vergennes anain wrote La Luzeme touching the Mississippi question. The envoy was urged to follow his former instructions and to leave it to Congress to discuss its pretensions directly with Madrid through its own plenipotentiary. It seems not unlikely that the despatch was elicited by intelligence of young Marbois' officiousness. ${ }^{22}$

In brief, then, while the claim of the United States before 1783 to a western boundary along the Mississippi was by no means an invulnerable one, its validity seems originally to have been taken for granted by Vergennes, as was also that of the even less well-grounded claim to a right to

It was feared that Spain might he detached from the war and that this might lead to peace on the hasis of the ufi possidetis. see Writings of James Wadison. I. $101 \mathrm{ff}$; IX. 86-9. On August 10, a second resolution was offered to empower Jay "to make such further cessions of the right of these United states to the navigation of the river Mississippi as he may think proper," etc. It was voted down unanimously, Iournals, XX. 853-1. The feeling in Congress at this latter date was anything but cordial toward Spain on account of the action of the Spanish commander in allowing the British garrison at Pensacola, on the surrender of that post to the Spanish forces, to retire to New York. See the order adopted this same date, loc. cit., 854.

$\Rightarrow$ Doniol, IV. 593-4. 
navigate the lower course of the river to and from the sea. Also, both the language and history of article XII of the Treaty of Alliance rendered plausible the American contention that, from the moment the treaty became operative, His Most Christian Majesty became guarantor of the territorial integrity of the United States. In his instructions to La Luzerne, however, of July and September, 1779, Vergennes not only rejected this interpretation of article XII, but assumed outright championship of the theory that the left bank of the Mississippi, northward of the Spanish boundary, was still English and that, therefore, Spain, being then at war with England, had the right to conquer it. In bringing about this change of attitude the material factors were, first, Vergennes' desire to remove the principal obstacle to Spain's hearty participation in the war, namely, fear of the Americans, and secondly, the misinformation that had come from Gérard as to the intentions of the so-called Anti-Gallican party in Congress and the extent to which the Mississippi boundary was desired by all factions; but there is no item of evidence showing an ulterior idea in the mind of the secretary that France herself would wish some day to recover Louisiana. When presently he came to understand the real trend of American opinion in this matter and the probable risk involved in attempting to traverse it, Vergennes returned to his original 
position, that it was for Spain and the United States to settle by themselves the questions in issue between them. 'This was conspicuously the position of the French government and its representative at Philadelphia when Congress voted the Instructions of June 15th, 1781,-a fact to be remembered in adjudging Congress' willingness at that time to entrust American interests so completely to the keeping of France. Whether, once rested with this power, France still adhered to her attitude of aloofness, which after all rested upon considerations of policy and not of right, is reserved for later consideration. 


\title{
CHAP'TER XIII
}

\author{
THE CRISIS OF THE REVOLUTION
}

On September 27th, 1780, Vergennes addressed the king the following letter:

Sire, your Majesty learned yesterday the details which the Count de Maurepas had to communicate with regard to the financial situation. They are truly alarming and seem to leave no other recourse than peace and a very speedy peace. Spain feels the same press of necessity that France does and her inclination is very evident. Does Your Majesty desire to instruct his ambassador at Madrid to encourage and promote this inclination? I have not the least fear, sire, that the Count de Montmorin would not acquit himself of such a commission, extremely difficult and delicate though it would be, with equal prudence and celerity. But once the avowal were made to spain that we have need of peace and that we rely upon her to obtain it for us, there is no one, Sire, who could answer for the consequences or assure Your Majesty that the interest of his reputation and his glory would not be compromised. I speak only of that, sire, since all other things are in comparison as nothing. I entreat Your Majesty to take the matter into consideration and to consult the Count de Maurepas. If the outcome of your deliberations favors an (ffort for peace through Spain, I very humbly besech Your Majesty to transmit me the order in writing. The circumstances which eonstitute the necessity of unhappy 
courses are soon forgotten, while the avil effects which ensue become but the more cvident with the passage of time. ${ }^{1}$

It requires no inordinate effort to perceive in this document the record of a critical moment in the history of the alliance and of the Revolution itself. Fortumately for the cause of American independence Vergennes' prompt and astute intervention with the king saved the day. Farly in October the secretary forced the retirement of the incapable Sartines from the Marine in favor of Castries and early in Jamuary he effected a similar reorganization of the Department of $\mathrm{War}$ under the talented Ségur.2 Meantime, as these changes indicate. the royal assent had been obtained to a new eampaign, though that it would probably be the final one of the war Vergennes at once recognized, not only because of the condition of the royal exchequer but also because of the situation on the Continent. With the powers annomucing in rapid succession their allerence to the Idaguc of Neutrals and with Holland breaking openly with England, the European horizon wore a smiling conntenance for France at

${ }_{1}^{1}$ Doniol, IV 198.

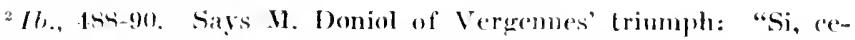
pendant, les petitesses des hommes tromvent encore at sagiter guand de grandes préoccupations dominent, ae ne sont ces pelitesses qui commandent. Il s'agissait du sort de la france en Europe; tout se suborionna à ce grand intêtêt, conséquemment fut remis anx mains de M. de Vergennes," ib., 490. 
the opening of 1781. Diplomatic combinations, however, are extremely kaleidoscopic affairs; besides which the recent death of the empress, by releasing the yet untested proclivities of Joseph II from a control that had usually been friendly to France, was a special factor of uncertainty. ${ }^{3}$ Then, early in 1781 came a formal offer from Joseph and the czarina of joint mediation between France and her allies, and Great Britain. Inasmuch as the offer represented the young emperor's initial venture in the field of Continental politics, Vergennes at once decided that it was to be treated with consideration. Moreover, he could but reflect that, if worse came to worst, so honorable a way to peace might prove very welcome. ${ }^{t}$

An open road to peace at the end, if it were

${ }^{3}$ See Vergennes to Montmorin, Feb. 14, 1781, ib., 544-5. "Il seroit souverainement malheureux que cette campagne si se passât comme la précédente sans rien produire d'effectif. Tout nous invite à songér à finir cette guerre; les moiens de la soutenir s'épuissent tous les jours, et la disposition de l'Europe qui jusqu'ici nous a été si favorable pent changér d'un moment à l'autre. Les Anglois ont de grands moiens pour tentér l'ambition de l'empereur et pour le satisfaire; l'offre que ce prince vient de nous faire de sa médiation peut nous faire conceroir l'espérance qu'il ne se rendra pas si aisement à leur séductions quand bien même nous n'aurions pas d'autres motifs de comptér sur sa persévérance dans l'alliance mais il n'est pas sans exemple que la vertu la plus ferme soit ébranlée. Pour parér à tous les inconvéniens impossibles à prévoir, nous ne devons nous occupér qu'à finir cette guerre; nous n'y parviendrons pas sans frapér un grand coup," $i b$.

"Vergennes to Montmorin, Jan. 2?, 1781, ib., 524-8. 
humanly possible, of a successful campaign-such, in brief, was Vergemnes' program for $\mathbf{1 7 8 1}$. One question remained, that of the military objective of the coming campaign, and on this there were three contending views. A party at court, composed of the adherents of Choiseul and Chatelêt sought to discredit Vergennes' policy by clamoring for a war of aggrandizement, to be waged especially in the West Indies." Spain, on the other hand, at last disillusioned of the idea of getting anything valuable except by fighting for it, was now demanding that she be assisted to conquer Gibraltar and Jamaica." Lastly, from America came the reiterated suggestion that, since American independence was the main objective of the war, North America was its natural and most adrantageous theatre.

'The despatch of Rochambeau and Ternay to America early in $\mathbf{1 7 8 0}$ has already been noted. For this determination on the part of the French government to add military assistance to naval and financial and for its aceeptance of the formula of "a constant naval superiority in American waters," which Ternay's squadron was

sLast Journals of Horace Walpole, II. 133-9. See also, for later efforts on the part of this same faction to discredit Vergennes' policy, Doniol, V. 186-7 and footnotes, and Reve dristoire diplomatique. VII. 550-1.

"Frances refusal to coöperate with spain in an attark upon Jamaica had been one of Spain's grievances in 1780, Doniol, IV. 196. 
designed to realize, the United States were principally indebted to La Fayette, who had spent all the first half of the year $\mathbf{1 7 7 9}$ in France pleading America's cause to Maurepas and Vergennes. ${ }^{7}$ Unfortunately, two-fifths of the army of ten thousand that had been intended for Rochambeau's eommand was bloekaded at Brest by a British squadron before it got away, while the naval portion of the expedition was rendered useless at Newport in the same manner shortly after its arrival. And the total result at the end of the first year of the expedition was that it had disappointed all the expectations it had aroused,had, in truth, created the impression on Ameriean minds of a promise made and not fulfilled. ${ }^{s}$

But a much more important consideration with those who at the end of 1780 besought France to lend the United States more extensive and direct aid was the state of the war in Ameriea at this period. Despite the alliance, American independence had never been so near collapse. The British army now held New York, the Carolinas, and Georgia, while the British fleet ravaged the coast. Congress was bankrupt and forced constantly to resort to the most wretched expedients to obtain money or to dispense with its employ-

'Charlemagne Tower, The Marquis de La Fayette in the American Revolution (Philadelphia, 190], 2 vols.), II. ch. XVIII; Doniol, IV. ch. V.

s'Tower, op rit., II. 125, 132, 15\%. 
ment. The Continental Army, without pay, food, or chothing and enlisted for short terms, was ever on the verge of dissolution. And the political situation was no better. With public spirit at the lowest ebb, the war had become throughout a great part of the country the desperate venture of a minority, sometimes a small minority. The Articles of Confederation were still in abeyance, the states were indifferent to their duties, the authority of Congress was flouted daily. 'To this situation the treason of Arnold was the natural climax."

The outstanding features of American conditions in the antumn of 1780 were already before Vergennes from the correspondence of La $\mathrm{L}_{11}-$ zerne. Indeed, it may be said that almost from the moment of the signing of the American treaties the secretary had undergone a progressive disillusionment in the military prowess and political competence of France's republican allies: "the inertia of democratic institutions," which had furnished him an argument in his efforts to reconcile Spain with the idea of American independence, he had soon found to be no mere

"On this lopic there is a superabmedance of material. See Doniol, IV. (h. VII; Tower, op. ait. II. chs. XX-XXII; I.ecy's American Remlution. (Woollourn, ed., New York, 1908), ch. III; Writings of Washingtom. (W. C. Ford, ed., 1. vols.), VIII and IX, perssim;

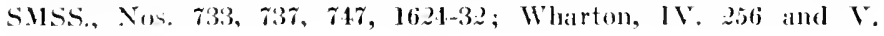
151, etc. 


\section{truism. ${ }^{10}$ Yet it is an interesting fact that to those Frenchmen who had come into personal touch}

10 "I avow I have but feeble confidence in the energy of the United States," Vergennes to Moutmorin, Nov. 27, 1778, Doniol, III. 581. A very censorious critic of the Americans was Kalb, whose letters to Broglie were probably seen by Vergennes, as they are to be found in the archives of the Department of Foreign Affairs. See e.g., Doniol, IV. $19 \mathrm{fu}$. Kalb charges the American character with braggadocio, dissipation, corruption, ir resolution, lack of patriotisn, Anglomania, SMSS., Nos. 821, 838, 845, 1971, 1987. For a partial confirmation of some of these strictures by a more lenient critic, see La Fayette to Vergennes, ib., No. 1609. See also a letter from the "Hon. J. Trevor to Mr. Secretary Fox," dated Ratisbon, Apr. 16, 1782. The writer gives an account of a conversation with the son of one of the Elector Palatine's ministers at the Diet, who had served as aide-de-camp to Rochambeau, and who had come away from America greatly disappointed with France's allies. Fifth Report (1876) of the Historical Manuscripts Commission, the Lansdowne Papers, p. 253. Nor were the French the only ones who were disappointed. "The generosity of our allies," wrote Washington in Aug., 1750, in a letter to the President of Congress, "has a claim to our gratitude, but it is neither for the honor of America nor for the interest of the common cause to leave the work entirely to them," Writings (Ford, ed.) VIII. 390. "Had America," began Crisis No. IX, written on the occasion of the surrender of Charleston, "pursued her advantage with half the spirit she resisted her misfortunes, she would before now have been a conquering and a peaceful people; but lulled in the lap of soft tranquillity she rested on her hopes, and adversity has only convulsed her into action." Vergennes, in coming to depreciate the military capacity and public spirit of the Americans as a whole and to emphasize the necessity of controlling Congress, showed a true appreciation of the character of the Revolution in its last days. Indeed, even the victory at Yorktown did little to break up the popular inertia that tied the hands of Congress. See La Luzerne's elaborate and very informing report on the situation at the end of 1781 , Revue d'Histoire diplomatique. V. 4?1-36. 
with the American cause, that cause had never appeared in more appealing light than at this moment of its greatest prostration. The explanation, I think, is to be found in the personal ascendancy of Washington, whose intrepidity and fortitude naturally stood forth all the more strikingly as the other mainstays of the Revolution fell away. ${ }^{11}$

At almost the very moment that Vergennes was intervening to prevent France's withdrawal from the war, a conference, consisting of Washington, the French commanders, the French envoy, and one or two others, was assembling at Hartford, Connecticut, to consider plans for the coming campaign in North America. It had already been determined that the objective of the campaign ought to be the capture of New York City. It was now further resolved that, in order to render this objective feasible, the French commanders should ask their government to send to America enough men to raise Rochambeau's force to 15,000, enough money to enable Congress to maintain a like force, and a sufficient fleet to command the American waters. The conference's decisions were conveyed to France by Rochambeau's son on a ressel detailed for the

"For the change in Kalbs opinion of Washington from unfavorable to favorable, $c f$. his letters of Oct. and Dec., 1777, to Brogtie, SMSS. Nos. 755 and 761. For some tributes by La Fayette, see ib., 1625, 1627, 1632. 
purpose by 'Ternay, late in October. In the middle of February, young Laurens sailed for France with a similar commission from Congress. He bore with him the friendly injunction of Rochambeau "to open his heart as to the state of this unhappy land, if it be not promptly and powerfully succored." ${ }^{2}$

The response of the French govermment to these demands was certainly not illiberal either in proportion to America's deserts or its own means. Measured, however, by the demands themselves it was meagre enough. The request that was met most generously was the financial one. Congress had asked for a loan of twentyfive millions livres. In return Louis gave outright six millions livres, to be spent in France under the direction of Franklin, and later consented to underwrite a loan of ten millions, to be obtained in Holland. The request of the Hartford Conference for more troops, on the other hand, was denied almost in toto, and even the contingent of Rochambeau's force that had been blockaded at Brest was kept back. As to naval aid, Vergennes expressed himself as follows:

${ }^{12}$ For the above, see Doniol, IV. ch. VII, and Tower, La Fayette, II. 159-63, 195- 200,270 . La Luzerne suspected that the sending of Laurens to France might represent an intention to supersede Franklin, Doniol, IV. 390-1 and fn. Laurens conduct in France, characterized as it was by youthful zeal and ignorance of diplomatic forms, was irritating to the French minister, but it seems clear that he should be credited with the king's endorsement of the Dutch loan, ib., 558-62; Wharton, IV. 317-55; passim, and 685-8. 
The count do Grasse, who commands our flect in the Antilles, has been ordered to conduct, sometime toward the approach of next winter, a part of his fleet to the coast of North Americia, or to detach a portion of it to sweep the eoast and to cooperate in any undertaking which may be projected by the French and American generals, or to form a part of it if they are mable to coopperate. 'The number of ships to be sent to the North will depend upon the need which the spanish have of our assistance. . . If they have made preparations for some guat enterprive. We shall have to lend them a hand: for if a serious blow is struck at the common enemy and it is successful, the advantage will be equally great for all the allies. The important point is to weaken the enemy, to crush him if possible: the locality is of little importance.

In short. the rendition of naval aid to the United States was subordinated to the project of assisting Spain in the West Indies, and. it may be added, before Gibraltar. ${ }^{1:}$

Why was Spain thus preferred to the United States! 'The question is easily answered. If France was under obligation to seeure American independence before she could honorably make peace, not less was she under obligation, now that Spain was ready once more to take an active part

${ }^{13}$ Doniol, IV. eh. XI; Tower, op, rit., II. ch. XXIV. In the interest of accuracy, it should be noted that the govermment's decision not to send more troops to America was receded from at the time of Grasces sailing for the West Indies to the extent of sending with him a reinforcement of six hundrod and sixty men for liochambeats force. On $A$ pr. 5, Grasse detached the sagittrire from hin thet to earry this force to Newport, where it arrised on June Ioth. Tower, pp. 283, 392-3. 
in the war, to obtain something valuable for that power too. But more than that, the Spanish marine was now in better fighting trim than it had been at any earlier period of the war. As between an ally able to contribute something to the common cause and one needing constant bolstering, good sense dictated that the real work of the campaign should be undertaken in coöperation with the former. On the other hand, this does not mean that Vergennes' effort to mininize the importance of the matter of locality is necessarily sound. Were England to be really crushed, then, of course, the way would lie open for France to satisfy both her allies to the completest extent, but of this there was, after all, little likelihood. Such being the case, however, it was altogether probable that, at the close of hostilities, England would be more strongly lodged in certain localitics than in others; and this fact might very conceivably work to the detriment of one ally as against the other. In point of fact, at the very moment he wrote the above quoted words, Vergennes already had in mind the possibility of France's acquiescing in a very substantial curtailment, from the American point of view certainly, of American independence, if an otherwise available opportunity for peace should offer itself.

Vergennes conmunicated to La Luzerne his government's decision with reference to the de- 
mands of Congress and the Hartford Conference in a despatch dated March 9th. In the same despateh and two later ones, dated respectively April 19th and $J$ une 30th, he further instructed the enroy as to the course of action that France expected on the part of Congress touching the diplomatic interests of the alliance: ${ }^{14}$ Congress was to be frankly informed that, in view of threatened developments on the Continent, peace might at any time becone of the utmost importance to France, and was, therefore, to be urged to aceept the proposed mediation without delay. By the same token, it also behooved Congress to endeavor to win the good will of the mediating powers by the moderation of its pretensions, "save in the matter of independence, which admitted of no modification." ${ }^{15}$ The American envoy at the mediation, on whose right to enter it on a proper footing France would unrenittingly insist, would be $\mathbf{J}$ ohn Adams. On account of Alams' unfortunate personal qualities which would "give rise to a thousand infortunate episodes calculated to exasperate his fellow negotiators." Congress ought to empower His Majesty's ministers to interpose to curb him

${ }^{14}$ Doniol, IV. 553-6, 589-91, 601-3; Jomrnals of the continental Congress, XX. 562-9, 669-74, XXI. 986-93. The extracts in Doniol are incomplete, but it is possible to smpplement them from Ia Inzerne's reports to Congress.

${ }^{25}$ Doniol, IV. 555. 
whenever necessary. ${ }^{16}$ Finally, Congress ought to be brought, albeit by the most delicate means, to realize the possibility that, in view of England's settled opposition to an outright recognition of independence and of the existing state of the war, the mediating powers might propose a truce based on the status quo. ${ }^{17}$ That the United

${ }^{16} I b ., 551$ fn., 589.

${ }^{17} \mathrm{Ib}$., 552-3, 601-3; Journals, XX. 672. The first hint that France might consent to the status quo for the United States is contained in Vergennes' despatch of Sept. 25, 1780, to La Luzerne, written at the moment when, as we have seen, the continuance of the war was in the balance. "Au surplus, M.," Vergennes wrote on this occasion, "je présume que le véritable ohjet des inquiétudes que lon vous a marquées c'est le statu quo; il seroit effectivement on ne peut pas plus fâcheux pour l'Amérique dans l'état actiiel des choses, et nous sommes bien déterminés à ne le point stipuler pour les Américains; ce sera ì eux à juger, lorsqu'il sera question de cet objet, de la persévérance on des sacrifices que les conjonctures exigeront de leur part. An reste, II., je désire que vous vous absteniez de traiter cette matière délicate dans ce moment cy . . . ." Doniol, IV. 536 fn. France, then, would not stipulate the status quo, hut would leave the question of its acceptability to Congress. However, Vergennes was very fearful that Spain, still in negotiation with Cumberland, would stipulate it, as she had in 1778. In his despatch of Nov. 27, 1780, he roundly denounced Florida Blanca's policy as grounded in passion, prejudice and selfishness, ib., 506-8. In his despatch of $J$ an. $2:$, 1781, he declared that if the king of Spain should stipulate the status quo in regard to the United States he would put them at the mercy of England and would give the Americans good reason to abandon the alliance. "Spain," said he, "will put her interests before everything else . . and she looks upon independence with regret," $i b ., 510-11$. Vergennes' later attitude on this question was formulated in a memoir in the hand of Rayneval, his secretary, on which is based in part his despatch of Mar. 9. This memoir comprises the following points: "1. It is for the 
States were profoundly interested in maintaining the integrity of their union was, of eourse, altogether indisputable. Indeed, the king himself was of the same way of thinking, both because of his plighted word and also because of his own interests, wherefore he would alter his present

king of Englaud, author of the war, to make some sacrifices for peace. 2. The first of the sacrifices to be made is inclependence for North America. 3. This independence may be assured either by a definitive treaty or a truce. 4. The king of England, whichever method is adopted, will be able to treat directly with the Americans, through the intervention of the mediating powers. 5 . The truce will run for 90,25 , or 30 years, ete. The Lnited states will be treated as independent in faet, and no restriction shall be imposed upon them in the exercise of the rights of sovereignty. 6. It would be desirable to avoid the status quo if possible; but in case that could not be, it will be advantageous to limit it to South Carolina and Georgia and to stipulate for the evacuation of New York. 7 . The propusition of the truce cannot be made by the king to congress, if it should be mited with the status quo, but if the two propositions are isolated, His Majesty will engage to procure Congress sinction of the truce, if he has the secret assurance that New York will be accepted [excepted?]. s. In case of a truce the king will propose to the Americans, if it is necessary to do so, a new convention the object of which will he to guaranice the Imerioins against attack by England after the expiration of the truce." In a word, while the king would leave the unpleasint husiness of proposing the stalus quo to the mediating powers, he would aceept it and bring Congress to do so, if it were confined to South Carolina and Georgia. There was a rumor in Bonton that the status quo had been aecepted for the United States, to apply to Grorgia, South Carolina, and Maine, as early as Ipril, lz80, continental Journal and Weekly 1drertiser, Ipril I3, 1zso. It may he that the uneasiness to which Vergennes refers in his despatch of sept. s; (supra), was caused by this rumor. 
resolution only when he saw "the absolute impossibility of obtaining peace without such a sacrifice." None the less, the sacrifice was one that lay "in the order of possibilities"; and, if it should become necessary, it would have to be accepted with resignation. "The greater part of the Belgian provinces had thrown off the Spanish yoke originally, but only seven had finally maintained their independence"; and "it frequently happens that circumstances give the law to the most powerful sovereigns, forcing them to modify plans the best conceived." 18

In short, Vergennes plainly indicated, that if an otherwise available peace offered itself, he would not resist the status quo for the United States indefinitely, though he had declaimed against it so bitterly a few months before; and further, that while to Congress would be reserved the formal decision in the matter, it would be expected ultimately to take the same position with as good grace as possible, and so save the king's face.

The passages above paraphrased, however,

15 Doniol, IV. 601-3. Vergennes continues: "Mais vous aurez la plus grande attention de ne parler que comme de vous-même et de ne point laisser apercevoir que vous y êtes autorisé, parceque dans ce dernier cas les Américains supposeroient que le Roi a d'avance pris le parti de les abandonner et ils croient tout perdn; Sa M’té est résolue de ne leur proposer aucun sacrifice, elle croit devoir laisser ce soin fâcheux aux deux cours médiatrices, si jamais il devient nécessaire," $i b ., 603$. 
touching the status quo, are from the despatch of June 30th and were never brought to Congress' attention. 'The conference which La Luzerne held with a committee of Congress on May 28th, ${ }^{19}$ and which led to the roting of the famous Instructions of June 15th, was based upon the despatch of Mareh 9th, in which, while the possibility of the status quo is suggested, the French government's attitude toward such a proposition is left somewhat vague. Even so, La Luzerne evidently thought it more in accord with the "delicacy" required by the situation not to bring forward this part of the despatch of March 9th till after Congress had defined the terms on which it would make peace, nor did he do so till Jume 18th. ${ }^{20}$ At the earlier conference the enroy's discourse was all of mediation, moderation, Mr. Adams' deficiencies, and the necessity of confidence in France. "If," said he, "Congress put any confidence in the king's friendship and benevolence; if they were persuaded of his firm resolution constantly to support the cause of the United States," they would order their plenipotentiary "to manifest a perfect and open confidence in the French ministers" and "to take no steps without the approbation of His Majesty." In other words, he invited Congress to surrender to France the diplomatic autonony of the United

\footnotetext{
${ }^{19}$ Journals of the Continental Congress, XX. 56:-9.

m)., 6.2 .
} 
States during the approbehing pease newotiations, Far troms spuming the imvitation. Consersis acepted it without stipulating a condition (1) revistorims a seruple.

by the openims parangraph of its Instructions

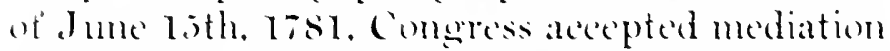
at the hands of 'lhoir Lomperial Majesties: by the serend. it mate independeme "by peace or truece" and the mantename of the alliane with France sinc qua nom enditions of a treaty: by the third and fourth, it indieated its enotidenee in Ilis Mlost Christian Maljesty and his ministers in the following terms:

As to disputad boundaries and other partioulars we refer you to the instruetions formery siren to $\mathbf{M l}$.

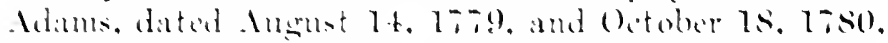
from which you "ill anily perede the desires and axpertations of congeres: but we think it mate at this distance to tie rom up by aboshe and peremptery directions upon suy ather sulgert than the two essential

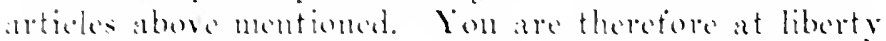
to soming the interests of the lenited states in such

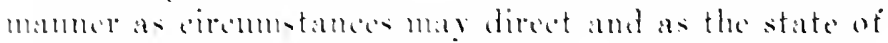
the belligerent and dispesition of the mediating powers maty require.

For thene purpenes you are to mathe the most andid and antidential communivations upon sll subjects to the

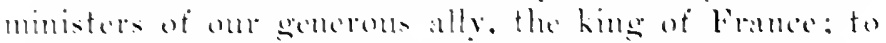
undertahe nething in the nepertiations tor peace or truce

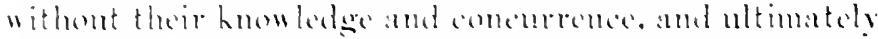

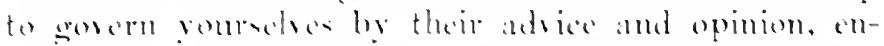

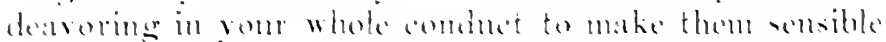

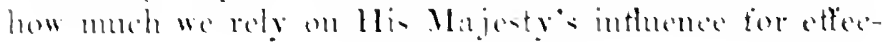




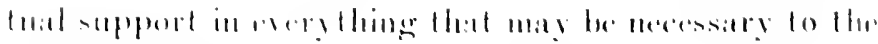

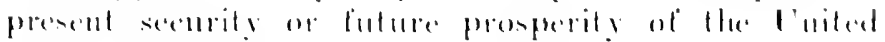
states of . Imeric:a, $=1$

I ittle wemder that the erities at the instructions declated that "mever befere hate onc state put itselt" at the merey at anothere so completely ancl

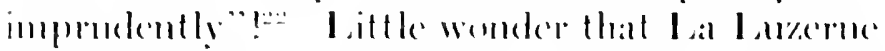

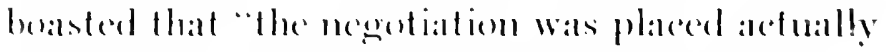
in the hamels af the kime sare om the equestion of

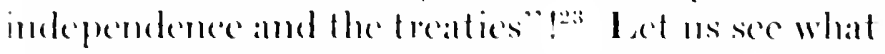
ware the entsiclerations that moved comperess to

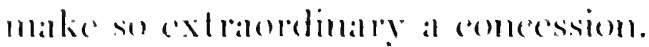

'The instructions were asked fort, as we hate

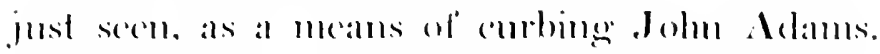
but mo semer were they roted tham delams was superseded by a commossion comsisting of himsell, Jay, Framklin, Jeflersom, and the cleter

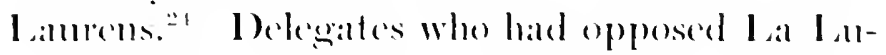

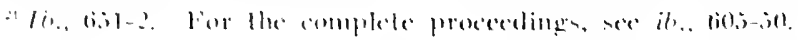

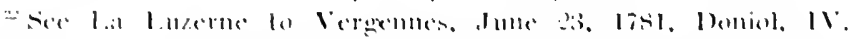

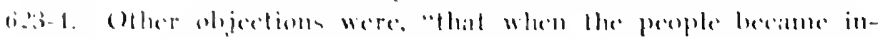

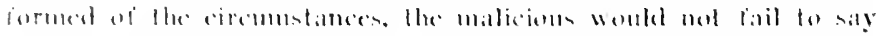

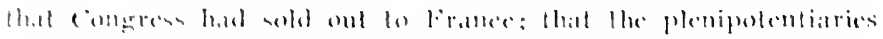

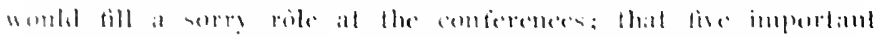

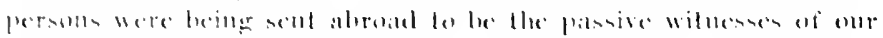

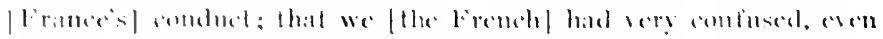

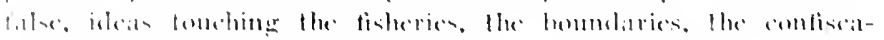

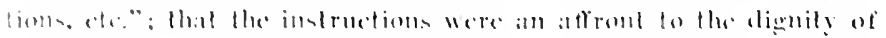

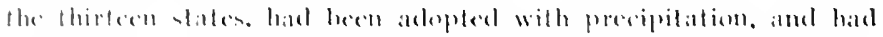

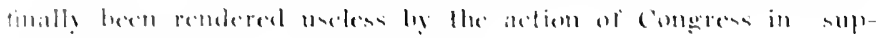
planting lalams with a romminsom. it.

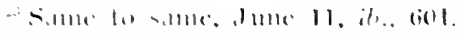

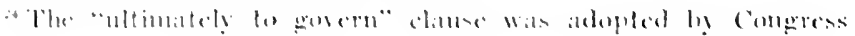

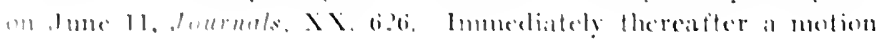




\section{zerne's demands in the first instance now renewed their attack, insisting that in addition to being}

that had been previously defeated, was reconsidered and carried to join two persons to Mr. Adams in negotiating the peace, $i b$, 698. Jay was elected on June 13, ib., 638. Franklin, Laurens, and Jefferson were added to the commission on June 14, ib., 648. The reason for a commission of five is suggested by Witherspoon thus: "They added more members to Mr. Adams and those from different parts of the continent. This removed every suspicion or fear that the interests of one part would be sacrificed to secure that of another," Thomson Papers, 100 (Debate of Aug. 8, 1782). Madison explains why Franklin and Jay alone were unsatisfactory thus: "The former being interested as one of the land companies in territorial claims, which had less chance of being made good in any other way than by a repossession of the vacant country by the British crown; the latter belonging to a state interested in such arrangements as would deprive the United States of the navigation of the Mississippi and turn the western trade through New York; and neither of them being connected with the Southern States." Writings of James Madison, I. 999 (Debate of Dec. 30, 1782). La Luzerne also thought that Franklin might be influenced through his interest in lands on the left bank of the Ohio to oppose Virginia's clain in favor of Great Britatn, and so advised Vergennes, Report of June 30, 1781, Doniol, IV. 629. 'The events of the negotiations of 1782 show that distrust of either Jay or Franklin was entirely misplaced. Neither Laurens nor Jefferson participated in the peace negotiations. The former, while on the way to fulfil a mission to Holland, in Sept., 1780, was captured by the British and later lodged in the Tower of London under a commitment for treason. He was still in the Tower when he was appointed peace commissioner, but was released Dec. 31, 1781, on the expectation that Cornwallis would be exchanged for him. However, he lingered on in England for another year. His conduct was made the subject of much contemporary criticism, which his hiographer succeds in answering, at least in part. D. D. Wallace, Life of Henry Laurens (N. Y., 1915), 354-419. Jefferson, who was governor of Virginia at the time, declined a place on the commission. 
mischievous the resolutions were also superfluous." The attack failed, however, even to induce a reconsideration of the question $:^{-15}$ and if the testimony of Madison is to be relied upon, the instructions were finally adopted in the form given above without dissent."

La Luzerne credited what-and not without justification-he regarded as a triumph for himself no less than for France, largely to personal factors. Early in May, he tells us, he had "opened his purse" to General Sullivan "the hero of Newport," a coup which had broken the backbone of the so-called "New England League" and secured New Hampshire's vote for the instructions from the outset. ${ }^{28}$ Also, as it happened, the "landless" state party, which was comparatively indifferent even when not hostile to American pretensions to a boundary at the Mississippi, had

$\approx$ Sce note 22 , above.

2a Journals, XX. 6.50.

2t Thomson l'apers, 65 (Debate of July 24, 1782). In meeting the attacks of memhers on the instructions, La Luzerne took the position that, "if we [the French] consulted our own interests rather thin those of our allies, we ought to desire that the Ameriean plenipotentiaries had all the powers that certain people wished to reserve to them." $M$ loo, he professed to be very reluctant to accept for France a trust that did not represent the deliberate will of Congress. "Y effet de ce langage, Monveignenr," he continues, "a ité de faire reconsidérer ces resolutions et de les confirmer, ains gur je l'enpérois permament. le président du Congrès una dit quelles étoient expediées par lifmme." Doniol, IV. $6: 1-5$.

$216 . .15 .608$ and fu. 
at this moment its two most influential spokesmen in Congress, Witherspoon of New Jersey and Jenifer of Maryland. On the other hand, the Adams and Lee families, champions respectively of the New England fishing interest and the Western land interest, both lacked their usual member. Certainly, La Luzerne himself could hardly have chosen a Congress more to his liking.

But while the personal factor may account for the votes cast by New Hampshire, Maryland, and New Jersey for the Instructions of June 15th it does not account for the votes of Pennsylvania, Virginia, the Carolinas, and Georgia. How, then, we may ask, did the men from these states, men like Madison and Jones of Virginia, for instance, reconcile such a remarkable abdication of power by Congress to a foreign, albeit allied, government with sound public policy?

La Luzerne's finesse in the matter of the status quo has just been mentioned. Nor was this, by any means, an isolated circumstance. 'To the same general category belongs also the fact that Congress, being ignorant of the terms on which Spain had entered the war, was in no position to previse the complicated tangle of obligations in which France would find herself if the war turned out to be only partially successful. ${ }^{29}$ 'There was,

${ }^{2}$ In this connection the following passage from a speech made hy Arthur lee in the course of the Congressional debate of Aug. $\therefore, 1782$, in faror of reconsidering the Instructions of June 15 , is 
in other words, so far as Congress knew, no compelling reason why France should not be trusted: on the contrary, there were exeellent reasons why she should be. Months before this her envoy had ceased chanpioning Spanish interests where these conflicted with American. More recently. abandoning the no longer applicable views of his eourt as to the establishment of a balance of power in Anrerica, he had given his assent to an invasion of Canada and had followed this up by urging

instructive: "It is not sufficient that the independence of these states in secured. But he doubts whether even that is secured by the iuntructions. He is afraid of the accompaniment. That we shall be so circumscribed in our boundaries that our indepencleace will be a nugatory independence. France in making a traty will be froverned by her own interest and from her long and close connection with Spain and prefer it to ours. Is it wise, is it proper to give a nation the absolute disposal of our affairs that is under the influence of two interests which she is bound to commlt in preference to that of these states? This unlimited eonfidence will render us despicahle in the eyes of France and less attentive to our rights. We have heen informed by a minister of France that Spain bas large claims on the lands beyond the Mombans. Her comduct shews that she means to support her claiu to that country. She wishes to confine us to the lands lying below the heads of the waters falling into the Atlantic. We are told that she thinks she has a right to possess herself of all to the westward. And shall we submit it to France, her old friend and ally, whether her claims hall be confirmed, and we be exchuded from the possession of that country" Thomson Papers, 9.5-6. I. we we the strongest critic of tle Instructions of June 1.5. Yet it will be noted that even he does not suspect that France is under any sperial obligations to spain in eonnection with the then cxinting war. .lno, it will be noted that he does not cluarge France with having championed spain's claims to the western country. 
renewed efforts in the Northwest. ${ }^{30}$ Rising above all other considerations, however, were these two: the state of the war and the source from which peace offered itself. The generality of Americans had long felt in June, 1781, that the fate of the United States rested almost entirely with France, whence it followed that Congress could not do better than to vest France outright with the trusteeship of American interests. 'The development at this moment of a prospect of peace through the mediation of powers that had never yet recognized American independence naturally confirmed this logic, and the more so since it was not known what degree of pressure these powers were prepared to bring in order to end the war. ${ }^{31}$

3o Phillips, The West in the Diplomacy of the American Revolution, 190-1 and 194, and notes. It was not La Luzerne's idea that the United States should retain the Western country necessarily ( $r d$. Doniol, IV. 622), but "he recognized that the possession of the Great Lakes would place the Americans in a much better position to negotiate with Great Britain," Phillips, loc. cit.

31 "In opposing the motion [for reconsideration of the Instructions of June 15], many considerations were suggested, and the original expediency of submitting the commission for peace to the counsels of France descanted upon. The reasons assigned for this expediency were, that at that juncture when the measure took place the American affairs were in the most deplorable situation, the Southern states being overrun and exhausted by the enemy ...; that the old paper currency had failed .... In the midst of these distresses, the mediation of the two Imperial Courts was announced. The general idea was that the two most respectable powers of Europe would not interpose without a serious desire of peace and without the energy requisite to effect it. The hope of peace was, therefore, mingled with an apprehension 
Upon the Instructions of Jume 15th there is impressed a twofold character. On the one hand, they constitute a real tribute to the essential magnanimity of the French design in intervening in the Revolution, to that quality of largeness about Vergennes' project that forbade an abandonment of American independence save in the face of conditions that meant reeognizable defeat for lrance herself. On the other hand, this tribute was no merely sentimental one: it was conditioned by the deliberate calculation that, in view of the actual status of the belligerent parties in America and of the auspices under which peace was to be negotiated - a peace which America needed no less than France,- - the United States could not act more prudently than to bestow the most ungrudging and unstinted confidence upon their ally. ${ }^{32}$

It thus becomes pertinent to inquire further, that considerable concessions might be exacted from America by the mediators as a compensation for the essential one which Great Britain was to submit to. Congress, on a trial, found it impossible, from the diversity of opinions and interests, to define any other chaims than those of independence and the alliance. A discretionary power, therefore, was to be delegated with regant to all other chams." Debale of Dec. 30, 1789, Writings of James Madison, I. zas-9, Madison, however, rather exaggerates the possibility of a roercive intention on the part of the medialors. Cf. la Luzerne's conference with the committee of Congress, of May 28, 17s1, Journals. XX. 562-9. Sce also Thomson P'apers, p. 65.

"2. Al worst," the apologists of the inslruclions urged, they "conld only be considered as a sacrifice of our pride to our intreses," Writings of Madisou, I. 300. 
what-British recognition of independence aside - were the expectations that underlay these instructions? 'The instructions themselves referred the American commissioners back to the instructions of August 14th, 1779, but this reference leaves us still in the dark as to the degree of confidence felt by Congress that the objectives so defined would be achieved. A much more informing document is the report of La Luzerne of June 13th, 1781, which, on the basis of a careful canvass of all varieties of opinion in Congress at this date, arrived at the following conclusions: 'that if the Ohio formed their boundary the Thirteen States would not complain; that, indeed, they would believe themselves under obligations to the king for all that they obtained more than this; that they would not reject the peace if circumstances necessitated some greater concessions; that the peace would be less agreeable in proportion as this line were hewn away from'; 'that if circumstances forced them to adopt as boundaries the mountains which divide the rivers that flow into the Atlantic from those that flow to the west, the peace would be accepted and ratified, but would meet with general criticism and would cool the ardor of French partisans, and it would be difficult to persuade the Americans that their interests had not been sacrificed'; that a treaty whereby any State were cut off from the Confederation could not be ratified; that they would 
prefer "to continue the war, howerer difficult it might be, to allowing England a single post in Georgia or in any other part of the 'Thirteen States"; that if it were necessary to depart from the ultimatum of 1779 , it was to be desired that the concession should be made, "not in favor of the English, but that the right of the Indians should be reserved to the intervening lands." $3: 3$ 'The recorded rotes on various amendments offered to the instructions while they were under discussion and on the secret instructions which it was at first proposed should aceompany them confirm these eonclusions to a striking degree. ${ }^{3 t}$

But as every one knows, the Instructions of June 15th had no influence on the negotiations leading to the Peace of 1783. Direetly this was due to the initiative of $\mathbf{J}$ ohn $\mathbf{J}$ ay, whose course

$\therefore$ Doniol. IV. 617-21.

it Ser especially fournals, XX. 608-15. The two articles of secret instructions adopted on .June $\tau$, ordered the commissioners to we their "utmont endeavors to secure the limits fixed exactly according to the deveription in your [their] former instructions," and if they failed in that, to make peace "withont fixing northern and western hinits," ib., 60s. The day following, however, Virginia having failed to secure an anendment to the instruction asked for $b z$ the committee that would have prevented any eession south of the Ohio, the secret articles were reconsidered and lost, ib., 615. La Iduzene, however, was somewhat suspicious lest some such instructions had been forwarded. "J'ai soupconné qu’il pouvoit y avoir des instructions quals [the plenipotentiariss] auroient ordre de nous cacher, mais rien naa encore confirmé ce soupcon, et la confiance me parôit illimitée," La Luzerne to Vergennes, June 13, 1781, Doniol, 15.619. 
will be considered in the following chapter as furnishing the best pragmatic test of the policy of the Foreign Office at that juncture. Back of Jay's decision, however, and making it possible was the Yorktown campaign, to which, accordingly, a few words must be devoted.

It will be recalled that Vergennes had set the approach of winter as the time for the Count de Grasse's visit to American waters. The admiral himself, however, evidently held quite different views on this matter, for in a letter to Rochambeau dated March 29th, one week after he had left Brest, he announced that he would reach Santo Domingo by the end of June, and contimued thus:

It will be toward the 15th of July at the earliest that I shall be able to reach the coast of North America. But it is necessary, in view of the short time I shall have to remain there-for the season will force me to leave in any event-that every preparation likely to aid in the success of your projects shall be completed, so that nothing may delay us an instant in beginning our operations..$^{3 \overline{3}}$

This letter reached Rochambean at Providence on June 10th. Already this gallant friend of America, who had been deeply disappointed by the king's rejection of the plan of the Hartford Conference, had conceived the idea that the Count de Grasse might yet "save the country."

Tower, op. cit., II. 398. 
Thus writing the admiral from Newport on May 28th he had urged "the gravity of the erisis in America, especially the Southern states, at this moment," and that, "without the naval superiority which he [the Count de Grasse] ean bring," "none of the means within our control can be made available." "'st: 'Then in a postseript, added three days later, he had further proposed that Grasse bring with him from the West Indies a eorps of five or six thousand men and twelve humdred thousand lizres in speeie, since this could be obtained at par in the Antilles, while in the United States it was at a premium of from twenty-five to thirty per eent. ${ }^{37}$ Now, on June 11th, he wrote Grasse a second time, ineluding duplieates of the earlier letter and postseript and repeating their recommendations with renewed urgeney.:"

Grasse's reply, which was dated at Cape Santo Domingo on the 28th of $\mathbf{J u l y}$, reached Newport on August 12th, and was favorable beyond reasonable expectation. The admiral amnounced that he would sail for Chesapeake Bay on Au-

se $16, ., 390$.

$37,16 ., 391$.

in $\mathrm{Ib}$., 398-400. Note also these expressions from a letter of June 16: "General Washington has but a handful of men .... This country has been driven to bay, and all its resources are giving out at once. The Continental money has been annihilated," $i b ., 397$. These letters are puhlished in full in Donials fifth volume and the originals are now in the Iibrary of Congress. 
gust 13th, as, he continued, this is "the point which appears to nue to have been indicated by you, . . . Messis. Washington, La Luzerne, and Barras, as the one from which the advantage which you propose may be most certainly attained." He would bring with him, he proceeded, three thousand men, from twenty-five to twenty-nine war-vessels, a quantity of siege artillery, and the sum of $1,200,000$ livres in specie. The one disappointing feature of the reply was the time limit it set for the projected operations. 'That he was able to come at all to the coast of North America, Grasse indicated, was due to the fact that the Spanish commander, Admiral de Solano, was not yet ready for active operations: but this condition would cease with the approach of the winter months, for which reason the French fleet and the troops it brought with it would have to leave the continent by October 15th.

As the whole expedition [the admiral wrote] has been undertaken at your request and without consulting the ministers of France or of Spain, although I have felt myself anthorized to assume certain responsibilities in the interest of the common callse, I should not venture to change the entire arrangement of their projects by transferring so important a body of troops. You will perfectly understand, my dear Count. how necessary it will be to mike the best use of this precious time ${ }^{3}$

'Thus the Yorktown campaign was due to the fortunate-not to say, fortuitous-coincidence of

sower, op. cil.. II. 101-t. 
three ciremustances: Rochambeau's friemdly solicitude for the Anerican canse, Grasse's patriotic willingness to stretch a point in his instructions for the gencral good. Solano's m meadiness, so characteristically Spanish, for the enterprise for which Grasse's expedition had been planned. In other words, Cormwallis' surrender owed little or nothing to the intention of the Fench gorernment itself. And by the sanne token, the results of the (ampaign of iz81 were from the point of riew of the French Foreign Oflice, somewhat disappointing. It had been hoped to hasten peace by st riking a decisive blow the immediate fruits of which were to go to Spain and fumish her sufficient inducement to puit the war. 'The decisive blow had been struck, true enough, but its direct beneficiary was America. The result-which was confirmed by Grasse's later defeat in the West Indies-was twofold: With Gibraltar and Jamaica both still salfely British a new eampaign had to be planned for the behoof of Spain. With the British forces abandoning all their inland conquests in the South. the application of the status quo to the Inited States became inpossible."

4he Sin this connection the secretary of Foreien Affates com-

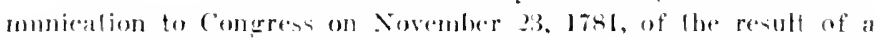
recent conference with 1 al lozerne hased on a despateb from Vergemmes dated september t. As presented by the enver, this despatch emphasizes framees championship of Ameriean intresents. her refusal to aceete to the terms of the mediation of

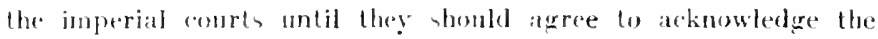


Nor may the reaction of patriotic American sentiment to the event at Yorktown be altogether ignored. Spontaneous as were popular jubilation at the triumph of the allied forces and gratitude to the French for their assistance, they did not blind Americans at all to the strengthened diplomatic position of the United States. Within a little over a week from Cornwallis' surrender the Massachusetts legislature passed resolutions ordering its delegates in Congress to press for instructions to the American peace commissioners to obtain British recognition of the right of Americans to share in the Newfoundland fisheries. ${ }^{41}$ With the introduction of these resolutions into Congress a fortnight later debate began afresh on the merits of the Instructions of $\mathbf{J}$ une 15th, to be renewed from time to time till the very end of the war. ${ }^{42}$ All efforts, however, to procure the outright repeal of these instructions crumbled before the argument that

American plenipotentiaries "in the manner most conformable to the dignity of the United States," and her rejection of a "plan of negotiation proposed by the mediating powers" which had "held up the idea" of the status quo for America. Journals, XXI. 11389. C'f. Doniol, V. 39-43. Doubtless, La Iuzerne's report of June 13 had demonstrated to Vergennes the unfeasibility of accepting the status quo for the United States except as a very desperate measure.

"Journals of the Continental Congress, XXI. $1122 \mathrm{fn}$.

See ib., XX1I. 44-5, 429, 458-60, XXIII. 870-5; 1)oniol, IV. 6256 and 696-701; Thomson Papers, 63-5 and 93-108; and Writings of Jarnes Madison, I. 226 and 994-301. 
such action, by the offense it would cause France, would do more harm than good, that while the instructions were doubtless a saerifice of pride, they were a sacrifice of pride to more substantial interests. $^{43}$ Furthermore. Congress had before it the explicit assurance of Vergennes, who was now chief-minister, that the king "would use his influence and credit for the adrantage of his allies whenever a negrotiation should render their interests a subject of discussion." 4

'This assurance suggested to Congress a way out of its difficulty. $\mathbf{B y}$ the resolutions of $\mathrm{J}$ anlary o.2nd, 178\%, the Instructions of June 15th were still left standing, but the American commissioners were ordered to contend "with an earnestness becoming the importance of an object on which a great part of the United States absolutely depend" both for commerce and subsistence, "for" an explicit acknowledgment of the common right of these United States to take fish in the North American seas and in particular on the banks of Newfoumdland," and "with equal earnestness," "for the boundaries of the United States as described in the instructions" of August 14th, 1779, and further, "to represent to His

${ }^{43}$ Above references. Ser also notes $22,24,27,29,31$, and 32 , above.

thournals, XX. 1138. Livingston makes the quite positive statement that this ausurance was what decided Congress to eontinue the Instructions of June 15 in effert after Yorktown, livingston to Jay, Jan. 4, liss, Wharton, V1. 178-9 fu. 
Most Christian Majesty" "the most sanguine expectations" of Congress that "His Majesty's friendship and influence will obtain for his faithful allies" both these objects. ${ }^{45}$

In other words, Congress solved the dilemma created by Yorktown-the dilemma, to wit, of American expectations on the one hand and French sensibilities on the other-by shifting the responsibility to the shoulders of the American commissioners. 'Ten weeks later Grasse's fleet encountered Rodney's in the Bahama Channel and was utterly defeated, Grasse himself being taken prisoner. Yet.-and it is a striking comment on the complex diplomatic situation in which the United States and France were mutually involved-the former derived distinct ad-

4. Ib., XX11. 44-5. Iivingston communicated the resolutions to La Imzerne, Jan. 24, Wharton $V$. 126-7. The resolutions were preeeded by Livingston's elaborate letter to Franklin of Jan. 7, 1782 , in support of the clains of the United States to a boundary at the Mississippi, to the navigation of that river, and to a share in the Newfomdand fisheries, Wharton, $V$. si-94. They were followed by the resolution of $A$ pr. 30, in which Congress expressed approval of Jay's course as detailed in his report of the preceding Oct. 3 (see next chapter); and by a second resolntion, adopted Aug. 6, 1789, ordering him to decline any propositions from Spain before transmitting them to Congress, unless his aceession thereto "was necessary to the fulfiment of the stipulation on the part of the United States contined in the separate and secret article" of the treaty witli France. Jominals of the Continental Congress, XX1I. 219-20 and 449-51. Whether these resolutions reached Jay in time to influence his conduct at the peace negotiations, 1 do not know, but conceivably they dicl. 
vantage from this defeat of their ally, perhaps indeed, greater advantage than they would have from her victory. For it was Rodney's trimph, the news of which reached London on the evening of May 18th, that encouraged the British govermment in the idea of attempting to separate America from her allies in the peace negotiations that were just to begin, the theory being that if the wastage of the American war could be brought to an end, England could afford to continue the war on the sea with the Bourloon powers. ${ }^{1 ;}$ 'That this assault upon their loyalty contributed materially to the success with which the American envoys met in the negotiations is altogether unquestionable. In short, America at this period was the lueky banker at the wheel of fortune: she ventured little, leaving that to other's but whoever won, she won.

\footnotetext{
thice Fitzmanrices Life of shellurne. 111. 191-5 and 203. For the comolatory momoir which Vergennes presented the king on Cirasse's defeat, see Douiol, V. 118-90. The noral he draws is that France must give the lie to Lord North's statement at the loginniner of the war, "que la France débule toujours avec supériorité, maic fuclle se relache dans ses efforts, autant que l'Angleterre multiplie et acroit les siens."
} 


\section{CHAPTER XIV}

\section{JAY'S MISSION TO SPAIN}

The story of Jay's part in the negotiations of 1782 is one that has never ceased to interest American students. In relating this well-known episode, I have not sought to avoid the problems of casuistry that, thanks to the opposed labors of the pious and the critical it has come to involve. At the same time, I have endeavored to organize my treatment of these problems in conformity with my main theme, wherefore I treat Jay's action primarily as a foil to French policy touching the negotiations. But as French policy at this point leaned heavily on Spanish policy, and as Jay imbibed at Madrid the point of view from which his course at the negotiations took its departure, I feel that a brief review of his mission to the latter country will not be inapposite. $^{1}$

${ }^{1}$ The following account of Jay's Spanish mission is drawn from his long reports to the President of Congress, of May 26 and Nov. i, 1780 , Oct. 3,1781 , and Apr. 28,1782 , which are to be found in Wharton, III. 707-34, IV. 112-50 and 738-65, and V. 336-77. The constituent documents of these reports will also be found in the Correspondence and Public Papers of John Jay (H. P. Johnston. ed., New York, 1890, 4 vols.), vols. I and II, passim. 
Jay set out for his post October 20 th, 1779 , and arrived at Cadiz January 22nd, 1780. Never received officially in the entire course of thirty month's sojourn at the court of II is Catholic Majesty, snubbed personally by nobility and officials, of ten without funds from the failure of his salary to reach him, put constantly to great expense in following the migratory court from pillar to post, embarrassed by the remarkable course of Congress in drawing on him when he had not a sou in prospect. put off again and again with the most transparent excuses. his correspondence subjected to official espionage and molestation-he underwent, without doubt, one of the most trying experiences that has ever fallen to the lot of an envoy elothed with the dignity of his government's commission.

Yet at the outset, Jay's mission was not without signs of promise. He was received by Florida Blanca with great promptitude and given strong hopes of considerable financial aid before the end of the year, as well as of a treaty which, at no remote date, would establish the long sought icia media between the legitimate interests of both Spain and America respecting the Mississippi question." But early in $\mathbf{J u l y}, \mathbf{1 7 8 0}$, came the news of the loss of Charleston. "The effect of" it." wrote Jay, "was as visible the next day as that of a hard night's frost on young leares."

2 Wharton, III. 709-11, 722-5.

${ }^{3}$ Op. cit., IV. 123. 
Meantime, Congress was constantly drawing on its envoy, and bills of exchange were constantly accumulating against him in the hands of the brokers, with the result that his financial difficulties were soon appalling. ${ }^{4}$ On July 5th, he had a long conference with the minister as to ways and means of meeting these bills, but, in his own expressive phrase, "not a single nail would drive." Nor was he more successful in his efforts at correspondence. Four successive notes remained unanswered, and an attempt to see the minister proved equally unavailing. ${ }^{6}$ Finally, on September 3rd, Don Diego Gardoqui, one of the friendly house of Bilboa merchants that since the beginning of the war had been carrying on a considerable trade in contraband with the United States, presented himself to Jay with Florida Blanca's compliments, and proceeded to propose point-blank that, in return for financial assistance, the United States should surrender their claims to the navigation of the Mississippi. Jay rejected the offer indignantly and was shortly after informed that even the limited credit which His Majesty had thus far extended was, for "reasons of state," withdrawn.'

${ }^{4} I 6 ., 111.722 ;$ IV. $122 \mathrm{ff}$.

: $I b ., 125$.

"Ib., 127-5.

r $1 b$., 133-5. There was mueh talk at this time and for some months later of sending Gardoqui to Ameriea to take the place filled by Rendon, as Miralles' successor, ib.. 741-2, 764. As a 
At this moment, fortunately, "some glorious reports from Ameriea arrived," and the Spanish govemment reconsidered its harsh deeision. On september 1.5th Gardoqui informed $J$ ay that if he could find credit for that sum. II M Majesty would be answerable for as mueh as one hundred and fifty thousand dollars." and eight days later the minister himself conf'erred with $J$ ay a second time on the subject of a treaty. The conference revealed, however, that a treaty was probably far distant. Actually, as Florida Blanea inadvertently adnitted, the Spanish monarch was determined not to recognize the United States hefore England did." Primarily this was because

matter of fact Cardogui did not arrive in the Inited states fill May, liss. For the negotiations then undertaken lotween him and Jay, who was now secretary of Forejgn Affairs, see Ban(croft, VI. 121-2.

sharton, IV. 139.

". Ifter a variety of other remarks of little importance he made a very inleresting olservation, which will help us to accomint for the delays of the court, miz.: That all these affairs eould with suore facility be adjusted at a general peace than now, for that such a partioular and even secree treaty with us might then he made as womld be very convenient to both. . . Throughoul the whole couversation [1]:y 23,1781$]$ the comot appearad much less cordial than in the preceding one; he seemed to want self-posession, and to that eanse I aseribe his incantionsly mentioning the groneral peace as the most proper season for eompleting ont political comnections. I had, neveptheless, no reason to superef that this change in his behavior arose froun any cause more important than those variations in temper and feclings which they who are macenstomed to govem themselves often experience from changes in the weather, in their hathth, from fatigne of husiuess, or other snch like accidental causes." Ib., 746. 
he feared the example and effect of American independence on his own dominions; but connected with this fear was Spain's desire, which Florida Blanca constantly stressed, to maintain her monopoly of commerce in the Gulf of Mexico. The Count, wrote Jay,

made several observations tending to show the inmportance of this object to Spain and its determination to adhere to it, saying with some degree of warmth that, unless Spain could exclude all nations from the Gulf of Mexico, they might as well admit all; that the king would never relinquish it; that the minister regarded it as the principal object to be obtained by the war, and that obtaincd, he should be perfectly easy whether or no Spain procured any other cession; that he considered it far more important than the acquisition of Gibraltar, and that if they did not get it, it was a matter of indifference to him whether the English possessed Mobile or not. ${ }^{10}$

Late in October $J$ ay received word that Gates had been defeated at Camden and that the elder Laurens was in the Tower. "Our sky in this quarter," he wrote, "is again darkened with clouds not in my power to dispel."11 Furthermore, this was the period of the Spanish government's negotiations with the Englishman Cumberland, which, as we have seen, menaced the United States with the status quo. Not until March, 1781, did Cumberland leave Madrid, that

\footnotetext{
${ }^{10} \mathrm{Ib} ., 145-6$.

${ }^{11} I b ., 149$.
} 
is, several weeks after Spain had ostensibly agreed to a fresh campaign. ${ }^{: 2}$

Meantime, by the resolution of February 15th, Congress had instructed $J$ ay to recede from his previous instructions so far as they insisted on the free navigation of the Mississippi below the 31st degree, "provided such cession shall be unalterably insisted on by Spain"; and on May 18 th $J$ ay received advices to this effect from the secretary of Congress. ${ }^{13}$ He greatly regretted the step, arguing that. inasmuch as Spain was herself now "at war with Great Britain to gain her own objects," she would be apt to "prosecute it full as vigorously as if she fought for" ours. ${ }^{14}$ Also, as certain papers that should have accompanied Lovell's letter did not arrive and the letter itself had passed through the post-office, he suspected that Florida Blanca knew as much about Congress' change of front as he did; and he

13 "If they have rejeeted all the overtures of Britain," wrote Jay in Nov., 1780, "why is Mr. Cumberland still bere? And why are expresses passing between Madrid and London through l'ortugal?" Ih., 145. Jay records Cumberland's departure in his report of Apr. 25, 178l: "Mr. Cumberland is on the road home. I much suspect that he was sent and received from mutual views in the two courts of deeeiving each other. Which of them has been most successful is hard to determine. . . As to the assurances of the minister on this subject, they are all of little consecfuence, became on such oceasions courts only say what nuy be convenient, and therefore may or may not merit confidence. 'lime and circunstances will cast more light on this subject." Ib., 38s.

${ }^{13} I b, 83+40$.

${ }^{14} \mathrm{Jb}, 743$. 
wrote: "The moment they saw that the cession of this navigation was made to depend upon their persevering to insist upon it, it became absurd to suppose that they would cease to persevere."

Finally on July 2 , taking the bull by the horns, Jay informed Florida Blanca outright that the great obstacle to a treaty between the United States and Spain had been removed by the action of Congress itself, and expressed the hope that His Majesty would "now be pleased to become the ally of the United States."1; 'Ten days went by and the communication still remained unnoticed by the Spanish minister. Jay then called at the Pardo and was informed that the reason for the seeming neglect was the press of business consequent upon the court's intention to remove shortly to San Ildefonso. On August 4th Jay himself repaired to the new capital and something over a month later was able to secure an interview with the minister, who had filled up the interval with alternating pleas of illness and business. ${ }^{17}$ 'The conference was resultless, but a second one a fortnight later produced a request on Florida Blanca's part that "Mr. Jay . . would offer him such a set of propositions as might become the basis of future conferences between him and the person whom he expected

\footnotetext{
15 Ib.. 514.

19 $I 6 ., 747$.

1: $I b ., 750-4$.
} 
II is Majesty would appoint." ${ }^{1 s}$ 'The request was complied with four days later. By the sixth article of the proposed agreement, the United States relinquished to II is Catholic Majesty "the navigation of the river Mississippi from the 31 st degree of north latitude... down to the ocean." Accompanying the article, however, was the explanation that "the offer of this proposition, being dictated" by the ciremnstances of the war," "must necessarily be limited by the duration of them and consequently that if the aeceptance of it should. together with the proposed alliance. be postponed to a general peace, the United States will cease to consider themselves bound by any propositions" now made in their behalf."

Of course the offer came to nothing. and on November 21 st we find $J$ ay writing Franklin that "this court continues to observe the most profound silenee respecting our propositions." "2n 'Three weeks later Jay seeured another interview with the minister, who informed him that a certain M. del Campo "had been appointed nearly three months ago to treat and confer" with him. but that "shortly after the court removed from San Ildefonso that gentleman's health began to decline" and that it had only insufficiently checked its deplorable tendency very recently. ${ }^{2}$

\footnotetext{
ast, tis.

${ }^{19} \mathrm{Ib}$, , $760-3$.

"It.. V... 346.

${ }^{21} \mathrm{Il} ., 31 \%$.
} 
However, Jay now began to pay court to M. del Campo, with whom he finally obtained an interview some six weeks later.

I found M. del Campo [he writes] surrounded by suitors. He received me with great and unusual civility and carried me into his private apartment. I told him that, as he was evidently very busy, I could not think of sitting down and wished only to detain him a few moments. He said that he was indeed much engaged but that we might, nevertheless, take a cup of chocolate together. ${ }^{22}$

A few weeks later Franklin wrote $\mathbf{J}$ ay from Paris requesting that he "render himself" there for the approaching peace negotiations as soon as possible. "You would," said the venerable doctor, "be of infinite service. Spain has taken four years to consider whether she should treat with us or not. Give her forty, and let us in the meantime mind our own business." ${ }^{23}$ The middle of June Jay left for Paris, expectant of renewing negotiations there with Aranda. But these expectations proved as footless as preceding ones had been. Aranda refused to show Jay his powers to treat-for the good reason that he had

${ }^{2} \mathrm{Ib}$., 356-7. For a good summary of the delays Jay had met with in Spain, see La Fayette to Vergennes, Mar. 20, 1782, ib., 266. For the episode of the invitation that was sent to Jay by mistake, to dine with the Spanish minister, and was declined when renewed to him in his quality as "a private gentleman of distinction," see $i b ., 373-7$.

${ }^{2}$ Letter of Apr. 22, 1782, ib., 321. 
none-and Jay refused to proceed without this preliminary."

Writers have implied that Jay went up to Paris in 1782 in a rather suspicions frame of mind, and it is certain that if he had ever been inclined to regard diplomatic questions in a sentimental light he had been pretty well cured of the tendency by the time he left iladrid. "In polities." he wrote lranklin at the close of this period, "I depend upon nothing but facts, and therefore never risk deceiving myself or others by a reliance on professions, which may or may not be sincere." Il. Ie, accordingly, warned congress of the futility of attempting to form alliances "on principles of equality in formâ panporis" ;" that the United States, to be "respectable anywhere," must be "formidable at home": ${ }^{2 \top}$ that we but deceived ourselves if we believed "that any nation in the world has or will have a disinterested regard for us." ".s rance, he acknowledged nugrudgingly, was doing a vast deal for America and often in a handsome and generous spirit that added greatly to the value of the favors she rendered: and he held, that. "so long as" she was faitiful to us, we were in honor hound to eontinne

${ }^{24} .1$ at to livingwlon, Nov. 17, 1762, ih., VI. 21-5, g8; same to same, 1)ere. 12. il., 130.

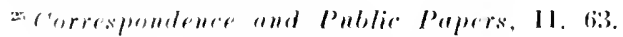

211 .. 20 .

2i Mharlon, 15. 11\%.

2 11 .. IIs. 
in the war for her objects as well as our own. ${ }^{29}$ At the same time, he was under no illusions as to the obligations of France to Spain. The latter power, he perceived, had been brought into the existing war only by special inducements, and he did not hesitate to inform Montmorin of his belief that one of these was "the exclusive navigation of the Mississippi and the Gulf of Mexico.",30 It is not remarkable, then, that he remonstrated strongly against the Instructions of June 15th. They had, he conceded, "an appearance of policy," but, he protested, they forced the American envoys to

receive and obey (under the name of opinions) the directions of those on whom ... no American minister ought to be dependent and to whom, in love for our country and zeal for her service, I am sure that my colleagues and myself are at least their equal.

Indeed, he preferred to resign his commission as peace negotiator rather than submit to such a control. But he did not resign; and as events were to prove, he had underestimated his own hardihood of purpose. ${ }^{31}$

\footnotetext{
${ }^{2}$ Correspondence and Public Papers, II. 283.
}

Wharton, IV. 137. This belief Montmorin challenged, but he later admitted that Spain was desirous of modifying American independence, Jay to Livingston, Apr. 98, 1782, ib., V. 363.

31 Correspondence and Public Papers, II. 71-2. 


\section{CHAP'TER XV}

\section{JAY AND THE NEGOTIATIONS OF 1782}

The story of the American negotiations for peace, which it was understood from the outset were to be carried on separately between the American envoys and such representatives as Great Britain should accredit for the purpose, ${ }^{1}$

"Vergennes to La Luzerne, Apr. 9, 178: "Au reste, M., quoique nous désirons que le Congrès n'entame aucune négociation directe et qu'il ne fasse point une paix séparée, . . nous sonmes et serons toujours disposés à consentir que les plénipotentiaires Américains en Europe traitent conformement à leurs instructions, directement et sans notre intervention, avec ceux de la cour de Londres, fandis que nous traiterons de même de notre côté, a condition que les deux négotiations chemineront d'un pas égal, et que les deux traités seront signés en même tems et ne raudront point l'un sans l'antre," Doniol V. 78-9. See also Oswald to Shelburne, June 9, 1782: "Dr. Franklin then said he thought the best way to come at a general peace was to treat separately with each party, and nuder distinct commissions to one and the same, or different persons. By this method many difficulties. . . would be in a great measure avoided. And then at last there would only remain to consolidate these several settlements into one genuine and conclusive treaty of pacification ... He explained as to the comnissions, that there might be one to treat with France, one for the Colonies, one for Spain, and, he added, one for Holland, if it should he thought proper." At the same time Franklin put in a hid for Oswald as the American negotiator. Iord Edmond Fitmanurice, Life of 


\section{begins to all practical intents with Franklin's} communication of July 9 th to the British agent Oswald, wherein was laid down the basis for a treaty of peace between the two comntrics. The first four items of this basis, labelled "necessary," were as follows:

1. Independence full and complete in every sense, and all troops to be withdrawn: 2. A settlement of the boundaries of the Thirteen States; 3. A confinement of the bommlaries of Canada to at least what they were before the Quebee Act, if not to still niarrower limits: 4. A frectom of fishing on the Banks of Newfoundland and elsewhere, as well for fish as whales, ${ }^{33}$

Williem, Earl of sllelburne (I ondon, 1876, 3 vols.), III, 207-8. 'The only effort male by the British govermment for a separate negotiation in the United States was throngh Sir Giny Carleton who arrived in New York on May 5, with a eommission to make "peace or war in North America." Later Carloton was authorized to make peace either with Congress or "fhrough Gicueral Washington" on the hasis of "unconditional independence." See Wharton, V. 105-6, 113, 417 , and 652, and V'I. 15-6. The arrival of Carleton evoled the Congressional resolutions of 11 ay 31,1782 , assuring His Most Christian Majesty of Congress' determintion "to hearken to no propositions for peace which are nol perfectly ronformable" to the Allianee, and in case such propocilions were made by the court of london, not to depart from llo' masures which they have heretofore taken for preventing delay, and for conducting the discussions of them [such propositions] in confidence and in coneert with llis Most Christian Majesty," Jouruals of the Coutinental Congress. XXII. 312-3. Sce also to same effect, the Resolutions of Oct. 4, 1782, ib., XXIII. 637-9.

"Fitmanrice, Life of shellurme, III. 213-1. Warly in the year a correspondence had arisen between Hartley and Franklin touching peace. The former had hinted at a separate prace between Finglind and Amerion, which suggestion the American had spurned. Wharton, V. 80-4 and 112-4. See also libanklin to 


\section{Jay's participation in the negotiations began} on Aigust 10th, when he and Franklin conferred with Verencentes as to the suflicieney of Oswald's

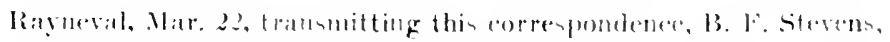

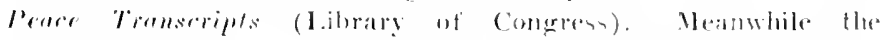

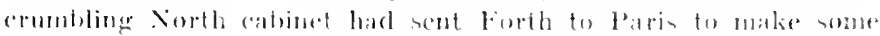

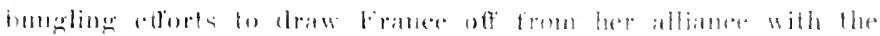

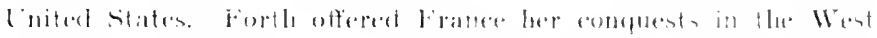

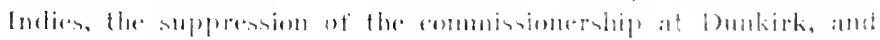

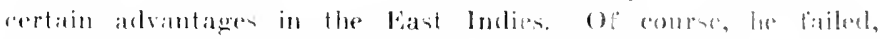

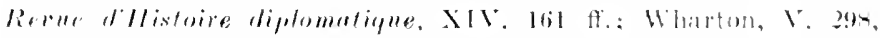

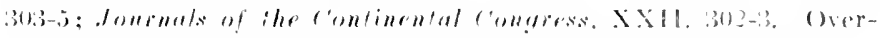
lappouge thin epinote, amel so antetating the formation of the lowek-

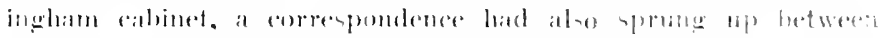

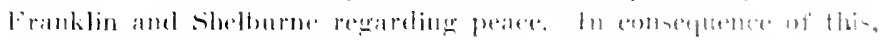
an arly as April l2, Oswald was sent to Paris hy Shelforme, whe

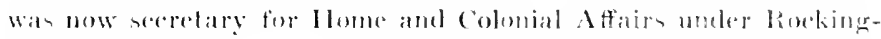
ham, fo sound him on the quention of prate. Franklin infurmed Oswald "that Imerieal was ready to treat, but only in concert with

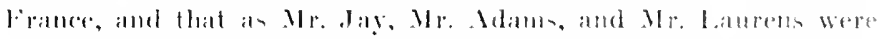

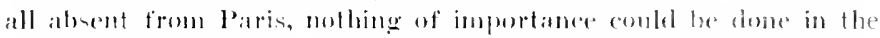

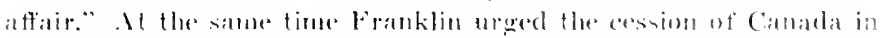
the jaterest of a durable peate and gave Oswall a minute of his

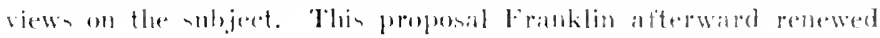

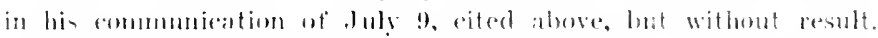

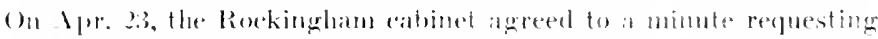

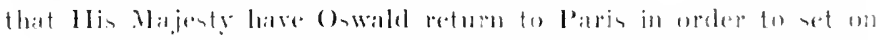
limet a megotiation with Franklin looking to a general peree and

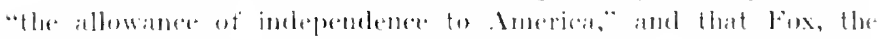

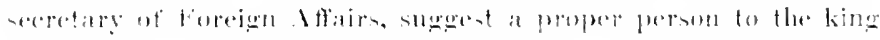

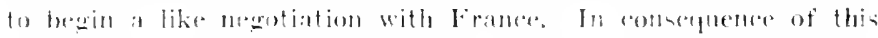
minute () wald was uent again to Parie to treat with Franklin,

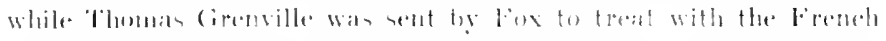

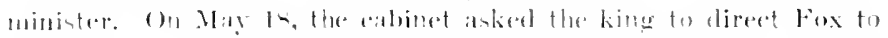

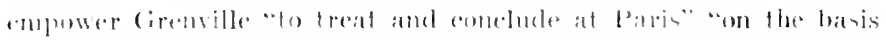

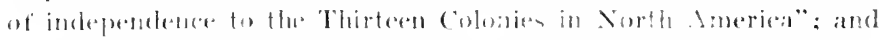
five disy late instrueted the latter in megotiating with Fronere to propwe the acknowledgment by England of the independerce of 
commission, which empowered that amiable gentleman to treat, not with the United States of America, but with "the said colonies and plantations." J Jay urged that "it would be descending from the ground of independence" to treat under such a description. Vergennes, however, urged

that names signified little; that the king of Great Britain's styling himself the king of France was no obstacle to ... France's treating with him; that an acknowledgment of our independence, instead of preceding, must in the natural course of things be the effect of the treaty.

America "in the first instance." Fox, interpreting these minutes as establishing a single negotiation, that with France, who, accordingly, was to be assured at the outset of England's intention to recognize American independence, now authorized Grenville to take over the whole business of peace-making. At first his plan was checked by the refusal of Vergennes to treat with regard to American interests, both because His Majesty had no power to do so and also because "the dignity of the king of England and of the United States required the establishment of a direct negotiation between the two," Vergennes to La Luzerne, June 28, 1782, Doniol, V. 88. In order to meet this objection Fox now empowered Grenville to treat with the king of France "and any other Prince or State," Fitzmaurice, op. cit., III. 214-7. Meantime, however, Shelburne had protested against the American negotiation being removed from his department and the king had sided with him. From the confusion thus resulting the situation was relieved by the death of Rockingham on July 1st, and the accession of Shelburne the day following to the Prime Ministership. Fox now left the cabinet and Grenville threw up his commission as envoy. Meantime, the Parliamentary Enabling Act had been passed, and on July 25 Oswald received his first commission, while, a fortnight earlier, Fitzherbert, the British minister at Brussels, had been appointed to take the Grenville's place. Fitzmaurice, op. cit., III. chs. IV and V; Doniol, V. ch. III.

${ }^{3}$ Wharton, V. 613-4. 
Upon leaving Vergennes' presence Franklin imputed the minister's attitude to a desire to remove "every obstacle to a speedy negotiation." But Jay, who had been led to believe by the mystifying conduct and language of another British agent, Grenville, that there was still some doubt about the British government's according independence, drew the conclusion that Vergennes was prepared to profit by this uncertainty by gretting Spain out of the war before England and America could come to terms. They wish, said he to Franklin, "to make their uses of us": the Count foresaw "difficulties in bringing Spain into peace on moderate terms, and that if we once found ourselves standing on our own legs . . . we might not think it our duty to continue in the war for the attainment of Spanish objects."

'Jay to Livingston, Wharton, VI. 12-9. This letter, ib., 11-51, is Jay's apology for the course clescribed in the text. It is also to be found in the Correspondence and Public Papers, II. 366-45:. The statement hy Grenville that is referred to is his assertion, upon leaving Paris, that Shelburme had no intention of granting America her independence, Fitzmaurice, op. cit., III. 246. 'This entirely unwarranted assertion was the source of the whole misunderstanding between Jay and Vergennes on the matter of independence. As is clear from his course with hoth Grenville and litzherbert, Vergennes was determined not to begin negotiations till he was definitely assured that the British government was ready to recognize American independence, Doniol, V. ch. III, passim; Fitansaurice op. cit., III. 251-2. Journals of the Continental ('ongress, Sept. 24, 1782, XXIII. 596-604. Jay, on the other hand. felt that Grenville's declaration was sufficient to call into question any mere statement by the British government heuceforth 
Jay was, of course, quite right in suspecting that the great difficulty in the way of peace was the necessity France was under of satisfying Spain, and from this it was a reasonable deduction that the French Foreign Office might be tempted to resort to underhand expedients to prolong the negotiations between the United States and England." On the other hand, it does

of its intentions as to independence, and that nothing could now remove uncertainty save the act of recounition itself, or what would be equivalent to an act of recognition if peace succeded. 'To his riew, therefore, Vergennes" willingness to forego the actual recognition of independence by Fugland till the treaty of peace was tantamount to willingness to postpone, till the end of the negotiations perhaps, the question whether there should be such a rerognition at all. Herein, he was wrong. "We maty juclge of the intentions of the court of London," Vergennes wrote La Luzerne, Mug. 14, "by their first propositions. If they have iudependence for their basis we may proceed; if not, we must hreak off," Doniol, Vr. 110.

s"When once inclependence has been definitely offered to the United States, if it is not followed immediately by pare it will not he difficult to persuade them that the continuation of the war has an entirely different object from their interests," Montmorin to Vergennes, Aug. 12, 178:, Stevens, Pence Transcripts. It should he noted in passing that, in an effort to reassure the $A$ mericans of his good faith. Shelburne had furnished Franklin with a copy of his tetter to Sir Guy Carteton of Jume 25 . This ketter mentions that Grenville had been instructed to propose American independence "in the first instance, instead of making it the condition of a general peace." At the same time, however, this letter also brought forward the point, "that if the negotiation is broken off it will undoubtedly be for the sake of" liance and spain and not Anerica, and that any delay in obtaining peace would be attributable to the same cause, Wharton, Vl. 15-6. While, therefore, this document was reassuring in one way, in another it confirmed Jay's suspicions. These suspicions were in formation be- 
not appear how the postponement, to the conchusion of peace, of British recognition of Ameriean independence-a matter which. Vergemmes had informed himself was a foregone result-wonld have delayed procecelings. 'The truth is that. owing to his misappreluension of shelburne's goodfaith, Jay was playing the very game that, by his assmmption. Verenentes wished to have played, that is, he was creating delay. Nevertheless, in so doing he forwarled American interests. For in an cffort to meet his demands and to bring to an end the delay they were causing. 'Townshend, acting for Shelbume, authorized Oswald on Septrmber 1st "to agree to the plan of pacification" that had been proposed by Franklin, "to the foll cxtent" of the "necessary" articles and, further, "to waive any stipulation" in behalf cither of British creditors of of the American loyalists."

But even this concession dial not abate Jay's defermination to treat on no other footing than as the representative of independent states; and there now followed a succession of events which galvanized his obstinacy to swift and positive

fore he lell spate. "Irance," he wrote livingolon, in his report

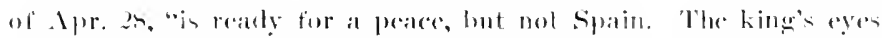

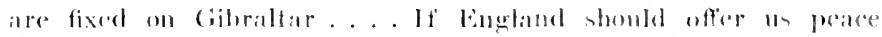
wh the lemes of our treaty wilh leance. the French court would be rery much embarassed by their alliance wilh spatin, and as yet

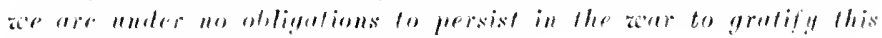
rourle (1he amphasis is mine), it.. $38 \% 3$.

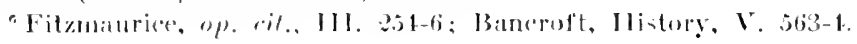


action. It should be mentioned that, on the same occasion when Oswald's commission had been first discussed with Vergennes, the conflicting claims of Spain and the United States in the region west of the Mountains had also been brought into the conversation. The minister himself, Jay records, "was very reserved and cautious; but $\mathbf{M}$. Rayneval, his principal secretary, who was present, thought that we claimed more than we had a right to." This tone on Rayneval's part, it is probable, was somewhat material in forming Jay's unfavorable opinion of the minister's argument on the question of Oswald's commission. Be that as it may, Rayneval next proceeded to develop his views to Jay more at length, and on September 7th sent him an elaborate memorandum in support of them and proposing that the lands south of the Ohio be divided into two Indian protectorates, the one toward the Mississippi to be under Spain, the one toward the Mountains to be under the United States, and that the lands north of the Ohio be left to England. ${ }^{8}$ Then on September 9th $\mathbf{J}$ ay "received certain information that on September 7th M. Rayneval had left Versailles and was gone to England, that it was pretended he was gone into the country, and that several precautions had been taken to keep his real destination a secret." Finally, on September 10th

\footnotetext{
${ }^{7}$ Wharton, VI. 23.

E Cf. p. 309 supra.

'Wharton, VI., 2S.
} 


\section{"a copy of a translation of a letter from M. Mar- bois to the Count de Vergennes against our shar- ing in the fishery" was put into the American's hands. ${ }^{10}$}

${ }^{20} 16$. . V. i40 and VI. 29. Jay states that he is "not at liberty to mention the manner in which this paper came" to his hands, but Fitzmaurice says that it was communicated "by means of one of the secret agents in the employment of the English government," op. cit., I1I. 257. Writers have attempted to cast doubts on the authenticity of this document, but these doubts are adequately met by the following passage from Vergennes despatch of $\Lambda$ ug. 1:, 1782, to 1,a Luzerne: "Le Sr. de Marlois propose un expédient pour arréter les espérances des Américains et les menées de $\mathbf{M}$. Samuel Adams; mais le Conseil du Roi juge que comme nous ne sommes liés par aucun engagement, nous n'avons aucune mesure à prendre pour prévenir les clameurs et les reproches, et toute démarche de notre part tendante à ce but seroit au moins prématurée; dailleurs, nous avons du tems de reste pour nous expliquer lorsque la matière des pêcheries sera sérieusement discutée entre les plénip'res Américains et le commissajre de la cour de Iondres." Doniol, V. 157. In his despatch of Jan. 4, 1783, to Jay, Livingston, Congress' secretary for Foreign Affairs, belittles the significance of Marbois' communication. He is not, he says, surprised by it, "since he [Marbois] always endeavored to persuade us that our claim to the fisheries was not well founded." Then he continues: "Yet one thing is very remarkable, and I hope evinces the determination of France to serve us on this point: The advice given to discourage the hope is certainly judicious, and yet we find no steps taken in consequence of it. On the contrary, we have been repeatedly told in formal communications since that period, "that the king would do everything for us that cir'umstances will admit.'.. This communication was made on the 2lst of last November from letters of the 7 th of Septemher.... Congress, relying upon it, have made no alteration in their instructions since the change in their affairs ly the blow the eneny received at Yorktown. This letter of Marbois, and the conduct of the court of France, evince the difference between a 
Jay was now thoroughly aroused and thoroughly alamed, especially for Americam interests in the West. France stood ready. lie now lielt

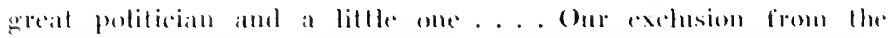

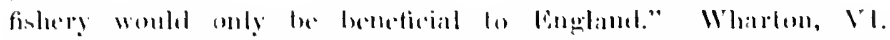
bi-so on. Thie argument would he more persmasive if the lefters

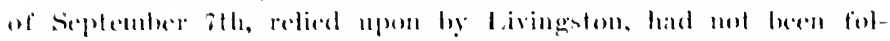
lowed by such eypressions an that queted above, from the despaterts

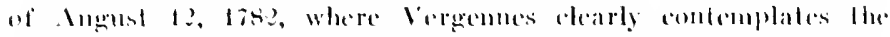
ponsilbitily of interening in the disenssion of the fisheries question betwern the Britinh and Ameriean megotiations, agaimst the Amer-

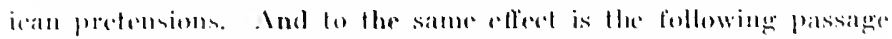

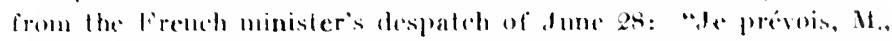

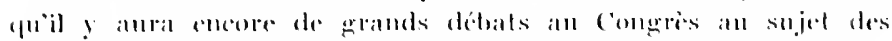

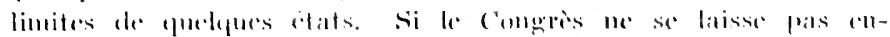

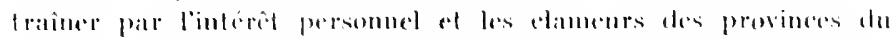
Nord, il emisagera ha pais comme le phes gerand ales bienfats

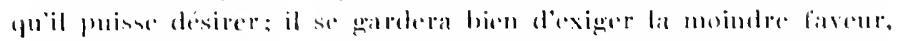

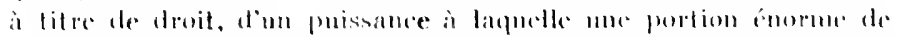

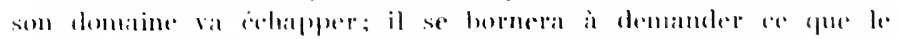

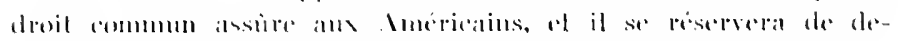
mander une plus arande estension loreque lemeletere hi pro-

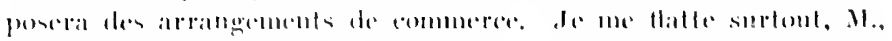

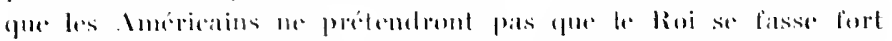

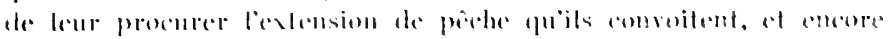

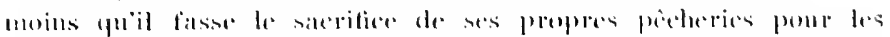

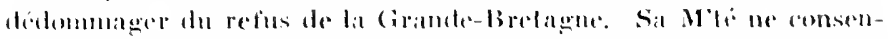

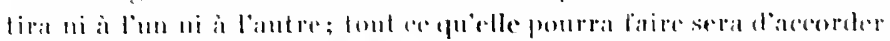
serens oflices selon que les circonstances le lui permettront: matis

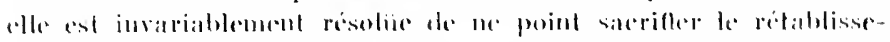

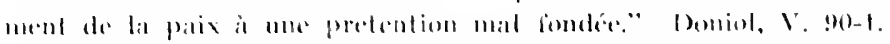

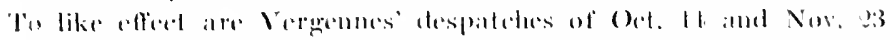

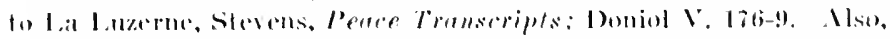

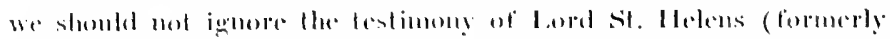

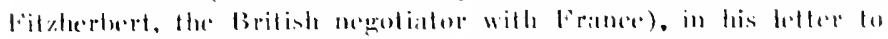

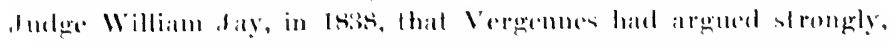
in lis: against the Imerieans heing athitted to the lisheries, 
comvineed, in rase the Inited States wombl mot grive Span the temilory she wanled in that regrion, to aid Har laller in nowotiating with langlamel lof il; and Rayourval, he helieved, had gene

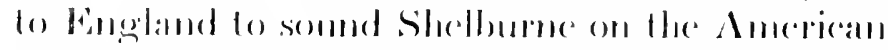
claims, to imporess mom him F'ance's disapporoval

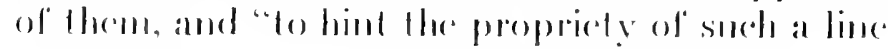
ats womb on the ome hand satisfy Syan and on

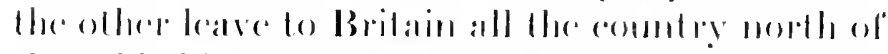

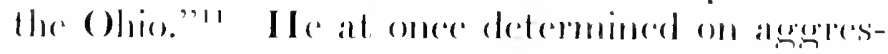

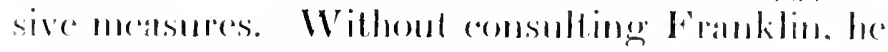

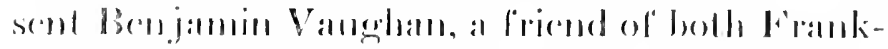

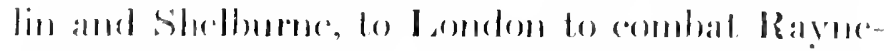

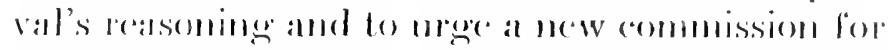
Oswald allhoriging him lo trall with "Mhe Inited States of Amorical." Valmohan's mission proved suceesstul, and upon the new hasis the newotiations proceseded till November 30 th, when "provisional aldicles" were signed, embodying the comditions of a treaty to be conchuded when termes of peater should "be alereed upon hetween Great

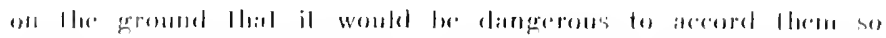

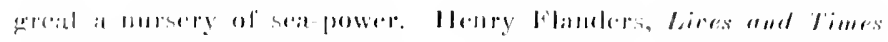

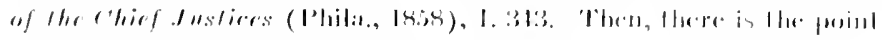

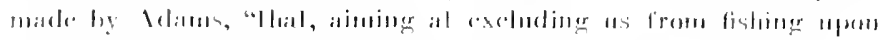

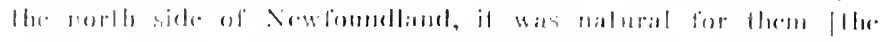

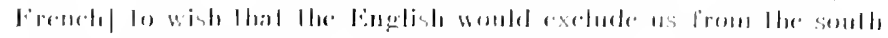

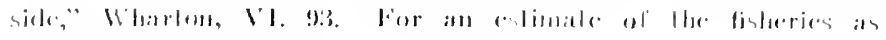

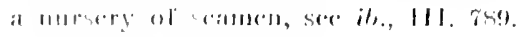

"Wharlon, V'. 2!).

11,., 29) :3, 15\% 
Britain and France," which did not occur till some six weeks later. ${ }^{13}$

Was Jay's conduct, which by their ratification of it became that of his fellow commissioners also, justifiable! 'The severest criticism meted out to the commissioners was that of Vergennes in his heated letter to Franklin of December 15th, which was called forth by the latter's announcement that he was about to forward the Provisional Articles to Congress by a vessel for which a passport had been secured from the king of England. ${ }^{14}$

I am at a loss, sir, [wrote the irate minister] to explain your conduct and that of your colleagues on this occasion. You have concluded your preliminary articles

${ }^{13}$ The Provisional Articles are given in Appendix $V$. A question raised in Parliament with reference to them was whether "American independence was to take effect absolutely at any period, near or remote, whenever a treaty of peace was concluded with the court of France, or was contingent merely, so that if the particular treaty now negotiating with France should not terminate in a peace, the offer was to be considered revoked and the independence left to be determined by events," Parliamentary History, XXIII. col. 306. Shelburne denounced the question as "unwise" and "unprecedented" and refused to answer it: "he was bound to keep the secrcts of the king ... the thing was done, the treaty signed and sealed, and whether good or bad, its production could not vary it," $i b$. What was the character of the contract in the provisional articles? This question was discussed in Congress, and the opinion arrived at by Wilson of Pennsylvania was that it was "contingently definitive," Writings of Madison, I. 448-50. See also a question raised as to the interpretation of the preamble, $i b ., 410$.

wharton, VI. 13\%-s. 
without any communication between us, although the instructions from Congress preseribe that nothing shall be done without the participation of the king. You are about to hold out a certain hope of peace to Anerica without even informing yourself on the state of the negotiation on our part. You are wise and disereet, sir; you perfectly understand what is due to propriety; you have all your life performed your duties. I pray you to consider how you propose to fulfill those which are due to the king? 15

'Technically, of course, the violation by the commissioners of their instructions was a matter exclusively between them and Congress, besides which these instructions had been voted with the mediation of the Imperial courts in view, while the negotiations of 1782 proceeded along quite different lines. Nor again, did the action of the commissioners technically violate the pledge given in the Treaty of Alliance, that the United States would conclude neither truce nor peace with Great Britain without first obtaining the formal consent of France. 'The

${ }^{3} \mathrm{Ib}$, 140. Iranklin's soothing auswer is given ib., 143-4. Franklin admitter that the Americans had "been guilty of neglecting a point of bienserance." But he urged that "this little misunderstanding.. . be kept a secret," as "the English, I just now learn, flatter themselves they have already divided us" (the emphasis is Franklins). It the same time, lranklin insisted that the articles ought to be sent to America, arguing that it would be better for Congress to have the commissioners account of them than the British account. On the 24 th, the articles were sent off, $i b ., 153$ fn. For a further expression of the attitude of the Foreign Office toward the conduct of the commissioners, sec Vergentes to Lia Luzerne, Dec. 19, ib., 150-2. 
Provisional Articles were not a separate peace nor did they "hold out a certain hope of peace." It may be admitted, however, that they were intended to convey a warning that the United States reserved the right to make a separate peace, if a final peace should be obstructed by France for reasons not covered by the Treaty of Alliance. In other words, the articles reclaimed for the United States that right to construe their treaty obligations which, when exercised in good faith, belongs to all sovereignties, and which Congress had surrendered by its instructions. ${ }^{16}$

1" There is, therefore, no necessary contradiction between Jay's language to Oswald and to La Fayette. "Upon my saying." Oswald wrote Townshend, Oct. 2 , "how hard it was that l'rance should pretend to saddle ws with all their private engagenents with Spain, he $[\mathrm{Jay}]$ replied: "We will allow no such thing. For we shall say to France: The agreement we made with you we shall faithfully perform; but if you have entered into any separate measures with other people not included in that agreement, and will load the negotiation with their demands, we shall give onrselves no concern ahout them." Stevens, Peace Transeripls. On Jan. 19, 1783, Jay wrote Ia Fayette, with referenee to the Provisional $\Lambda$ rticles, thus: "It appears to me singular that any cloubts should be entertained of American good faith. . . Ameriea has so often repeated and reiterated her professions and assurances of regard to the treaty alluded to [the Treaty of Allianee], that I hope she will not impair her dignity by making any more of then." correspondence and Public Papers, 111. 25. But see also Ldward Chamning, History of the l'nited States, I1I. 384-5, for proof of the fact that Jay urged Oswald to press his govermment to mudrertake the reconquest of West Florida from the Spaniards, and cren suggested to that end that some of the British troops at New York and Charleston be used for the purpose. In this way the Britiuh forces in the United States would have been weakened; the Brit- 
'The question that at once prompts itself' is whether the United States, having regard to the kinds and scope of the assistance they had had from France, were altogether free to elaim the prerogatives of sovereignty in relation to their engagements with that country. No doubt, in theory the United States were "sovereign and independent" allies of France; but more imposing than any theory is the fact that, at the very moment of comminicating the Provisional Articles to Vergemnes, Franklin was obliged by instructions from Congress to solicit a fresh loan from His Most Christian Majesty. ${ }^{17}$ And the circumstance is indieative of what had been the actual situation from the very outset of the alliance. But such being the case, was not the Foreign Office at liberty, within reasonable limits, to make

ish eoncession to the United States of the right to navigate the Mississipui would have been rendered effeetive; and Spain would have been humiliated.

${ }^{17}$ Congress wanted a loan of twenty millions, and on Dee. 21 a loan of six millions was extended, Wharton, VI. 152 fn. Some writers have attributed this concession to the pleasing effects of Franklin's note of Dee. 17, quoted above. It is mueh more probable that the concession was instigated by the consicleration suggested in the text, that so long as Congress was the reeipient of snch favors from France it was not likely to cut loose from the French leading-strings. In justice to the commissioners, however, one should recall the principle invoked by Jay in Span, that the United States, being a sovereign nation, were tree to borrow money "on the same consideration that other nations did," namely, "the repayment of the principal with interest," and accordingly, withont putting their more permanent interests in pawn. See Wharton, IV. 134-6. 
the best arrangements it could in the interest of a cause which was certainly not less that of America than of France; and granting the measures so taken to have been taken in good faith, were not the United States in honor bound to shoulder their legitimate consequences! Jay himself had owned that it was farcical to seek an equal alliance in forma pauperis. It was, perhaps, a little less than honest to pretend to maintain one on that footing.

"The separate and secret manner in which our ministers had proceeded with respect to France and the confidential manner with respect to the British ministers," Madison records, "affected different members of Congress very differently." "Madison himself thought the conduct of the commissioners censurable, taking substantially the point of view just expounded. He admitted that France had mingled too much artifice in her dealings with America, and that her truest policy would have been a more straightforward course. He also conceded that the ties of France with Spain, "whom she had drawn into the war, required her to favor Spain, at least to a certain degree, at the expense of America."19 None the less, he contended that, "instead of coöperating. with Great Britain" to take advantage of "the embarrassment in which France was placed by

${ }^{18}$ Writings, I. 404.

${ }^{19} \mathrm{Ib}$., 996. 
the interfering claims of Spain and the United States," the envoys "ought to have made every allowance and given every facility to it consistent with a regard to the rights of their constituents." The facts alleged by the envoys, he continued, showed no "hostile or ambitious designs" against our claims on France's part, nor any other design "than that of reconciling them with those of Spain": wherefore, an impartial world must regard the action of the commissioners as striking "a dishonorable alliance with our enemies as against our friends." Indeed, a measure of consideration had been due Spain herself, for notwithstanding the disappointments and indignities which the United States had received from her, "it could neither be denied nor concealed that the former had derived many substantial advantages from her taking part in the war, and had even obtained some pecuniary aids." ${ }^{20}$

Rightly or wrongly, the commissioners modelled their course upon more robust principles. Jay, a quick and sensitive temperament, who had in Congress shown himself not a little compliant with French views, had been cast by his experiences in Spain into an attitude of patriotic selfassertireness, an attitude to which the Congressional instructions added fresh fuel. Adams' hardy provincialism needed no special incentive to patriotic self-assertion, though it had this in his "Ib., 118. 
intense interest in seeing Massachusetts restored to her fishing privileges off the Grand Banks. Franklin, burdened with years, was perhaps overborme to some extent by his more vigorous colleagues but he also felt, and had from the first, a keen desire to see the United States reach to the Mississippi. ${ }^{1}$ All these men, moreover, had been of the pioneers of American independence, among the first to conceive a national destiny for the American Provinces.

But the inmediately provoking cause, of course, of the independent policy adopted by the commissioners was Jay's suspicions, and these, it has been frequently urged by writers, were not altogether well-placed. Nevertheless, I think it has to be conceded that most of Jay's errors were rather as to the motives represented by certain facts than as to the facts themselves or their natural tendency; and even such mistakes as he made were compensated for to a singular degree by facts that he did not know. 'Ioday, however, the essential elements of the situation that confronted the commissioners are plain; they may be summarized thus: First, the necessity France was under to obtain peace as speedily as possible; second, the positive obligation she was under not

a See Jay's testimony on this point, Correspondence and Public Papers, 11. 390. Sec also the commissioners' letter to livingston, Dec. 14, in which Franklin assents to the statement, "Wr knew this court and spain to be against onr dains to the Western comintry," Wharton, V1. 139. 
to accept peace until Spain was satisfied $;^{22}$ third, British resistance, ever becoming stiffer, to Span's prineipal demand, the surrender of ( $\mathrm{ii}$ braltar ${ }^{23}$ fourth, Spain's scarcely secondary interest in thrusting the Americans back from the Mississippi; fifth, Vergennes' denial that the reciprocal guaranty of the 'Treaty of $A$ lliance was ret operative except as to American independence: sixth, his entire disbelicl that there was any likelihood of England's eonceding the American claims, either as to the fisheries or the Western lands, and his repeatedly announced intention of bringing the Amerieans to reason if they persisted in untenable elaims $;^{24}$ seventh and

22 Peace. Verpemes had written in Auqust, 17\%9, could be concluded only on two conditions: "la satiofaction plónicere du roi d'Espagne et la reconmassance des Etats-Lonis darn leor etat de libertie et d'independinee," Donjel, IV. 339-40.

a liven on his first mission to Isondon kayneval hat reported the Brilich reluctance to the cession of Gibraltar as almest insuperable.

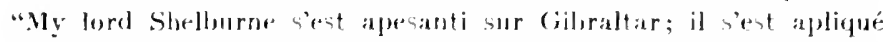

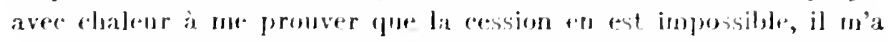
parlé de la résistance que ert artiele epronveroit an conseil; que le lord Keppel, lorsqu'il lui en a parlé, lui dit nettement qui si on parloit de ceder (jibraltar, il probelroit son rhapeau et son

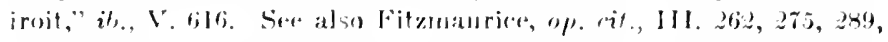
$30.5,312$.

${ }^{2}$ Sere nole 10 supra. Ser also Vergennes to I a Juzerne under dates of ()et. It and Nov. 23, Izse, Stevells, Peare Transeripts; Joniol, V. Iiti- Note the following expressions from the latter dorument: "J a Roi ne sera moins exart à les tenir de son côté [certain eonditions], mais il n'rn existe ancune [eondition] dans nos traté qui loblige a prolonger la guerre pour soulenir les préten-

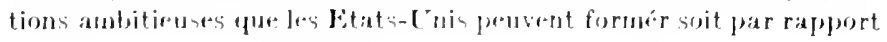


last, the procedure governing the negotiations, whereby the Americans were left to shift for themselves, while the Foreign Office took the Spanish interest under its wing from the beginning. No one of these facts was necessarily of fatal import for American interests, but the ensemble is somewhat impressive. To it, moreover, may be quite legitimately lent the coloration of one or two other circumstances. The first of these is Rayneval's early mission to England. 'True, the primary purpose of this had to do with Gibraltar, but the young secretary took what opportunity the occasion offered, none the less, to disparage the American claims with the British ministers, if quietly yet not ineffectively. ${ }^{25}$

à la pêche, soit par rapport à l'etendue des limites .... Malgré toutes les eajolleries que les ministres anglois prodiguent aux Américains, je ne me promets qu'ils se montrent facils ni sur les pêches ni sur les limits...,"ib., 177. The earlier doeument is even more positive in tone. It is interesting to eompare this tone with that taken by Rayneval with reference to Gibraltar: "le Roi, s'il en étoit besoin, se feroit un devoir d'exhorter le roi d'Espagne à être modéré dans ses pretensions, mais Sa Majesté ne pourroit ancunement parler de l'abandon de Gibraltar," $i b ., 618$.

whe following extracts from Rayneval's report of his eonferences with Shelburne are the signifieant ones: "Mais mylord craint les $\Lambda$ mérieains et les Hollandois; j’ai eneore dit qu'il $y$ auroit moien de les dérouter, prineipalement en leur laissant ignorer l'état de la négociation entre la France, l'Espagne, et l'Angleterre. Cet article tient infiniment à eoeur à mylord Shelburne," Doniol, V. 614. (It is interesting to compare this suggestion with Vergennes' later complaint to I'ranklin, that the Americans had not tried to inform themselves as to the state of 


\section{Again, one should, perhaps, not altogether ignore this further consideration: "The French are interested in separating us from Great Bri-}

the Angio-ferencli negotiation, note 15, supra). "Est venu le tour de limérigue; mylord shelburme a prévu quils auroient beallonp de difficultés avec les Américains, tant par ripport aux limites que par rapport a la peche de Terre-Newe, mais il espère que le Roi ne les sontiendra pas dans leurs demandes. J'ai répondu que je ne doutois pas de lempressement du Roi a faire ce qui dépendra de lui pour contenir les Américains dans les bornes de la justice et de la raison; et mylord ayant désiré savoir re que je pensois de leurs pretentions, jai répondu que jignorois colles relatives à lat péche, mais que telles quelles puissent être il me sembloit qu'il y avoit un principe sûr à suivre sur cette matière, savoir, que le pêche en haute-mer est res nullius et que la pêrbe sur his côtes apartenoit de droit an propriétaire des côtes, ì moins de dérogations fondées sur des conventions. Quant a l'étendue des limites j’ai suposé que les Américains la puiseroient dans leur chartres, e’est à dire qu'ils voudront aller de l'ocean à la mer du Sud. Mylord shelburne a traité les chartres de sottises, et la discontion n’a pas été poussée plus loin parceque je n’ai voulu, ni soutenir la prétention Américaine, ne l'anéantir. J'ai semlement dit que le ministre $\Lambda$ nglois devoit trouver dans les négociations de 1754 relatives a lohio les limites que l'Angleterre, alors someraine des 13 Etats-mis eroyoit devoir leur assigner," ib., 6ts9. 'Jlue reference to the negotiations of 1754 is explatined by the following prassage from the memoir which Rayneval had ouly a fow days before this presented to Jay on the Mississippi question: "It is known that, lefore the 'Treaty of Paris, France possessed Louisiana and Canada, and that she considered the savage people situated to the east of the Mississippi as cither independent or as under her protection. This pretension eaused no dispute; England never thought of making any [pretension?] exeept as to the lands situated towards the souree of the Ohio, in that part where she hald given the name Allegheny to that river." Whartom, Vl. 25. "The reaction of the Euglish ministers to what Rayneval had to say about the American elaims is recorded 
tain ... but it is not their interest that we should become a great and formidable people."'26 'The words are Jay's, but Vergennes himself had said as much time and again.

In short, the commissioners were confronted with an appreciable danger, in meeting which they displayed sagacity and spirit. However, it may still be a question whether their policy really netted the United States a profit or a loss; and in fact, it has been argued that it did the latter. The pivotal fact upon which this contention hinges is the rejection by Shelburne on October 20th of a draft treaty which had been agreed to by Oswald, and which, in addition to granting the Americans everything they had asked for with reference to the fisheries and the West, accorded the United States a northern boundary that included much that is today Canada and maintained complete silence as to the claims of British creditors and of the loyalists, whereas the

by Shelburne's biographer, thus: "They then proceeded to speak about America. Here Rayneval played into the hands of English ministers by expressing a strong opinion against the American claims to the Newfoundland fishery and to the Valley of the Mississippi and the Ohio. These opinions were carefully noted by Shelhurne and Grantham," op. cit., III. 263. When the Provisional Articles arrived in London, Rayneval was there on a second mission. Being shown them he remarked upon the embarrassment that the article according the United States the navigation of the Mississippi would canse Spain, but elicited a very unfeeling response from Shelburne, Doniol, V. 229.

${ }^{28}$ Wharton, VI. 48. 
Provisional Articles of November 30th made certain concessions on the two latter points and drew a much more restrictive northern boundary. Now, it is urged that the rejected draft treaty was in entire accord with 'Townshend's letter of September 1st to Oswald, that the motive of the British minister in authorizing such extensive concessions to the Americans was the hope of separating them from the French, that Vaughan's mission, by revealing to Shelburne that this end had already been accomplished, instigated him to retract in a measure his policy of eoncession, and that, therefore, the unfavorable differential between the draft treaty and the later Provisional Articles must be eharged against Jay's headiness and precipitaney. ${ }^{2 \tau}$

The argument is ingenious but not convineing. To begin with, it will be reealled that, whatever the ulterior motive of 'Townshend's letter, it was called out immediately by Jay's demand that the British govermment should recognize American independence preliminary to treating. Again, while this letter enpowered Oswald to agree to "a settlement of the boundaries," there is plainly some difference between an adjustment of boundaries and such a cession of territory as that made by the draft treaty of lands to the west of the

${ }^{27}$ Phillips, The West in the Diplomacy of the American Revolution, pp. 220-1. See also to same effect Works of Benjamin Franklin (ed. Bigelow), VIII, 164 fn. 
Mountains and later repeated by the Provisional Articles. But again, it was not Vaughan's mission that first informed Shelburne and his associates that there was a rift in the French-American lute, it was Rayneval's mission and his attack on American pretensions. Finally, the assertion that Vaughan's mission persuaded Shelburne that the objective of his policy had been realized and that, consequently, he might abandon the policy, is mere conjecture, and not very plausible conjecture at that. Unquestionably, it was Shelburne's purpose to divide France and America but it was also his purpose to keep them divided till peace was obtained, and peace had not yet been obtained when, on October 20th, he rejected the draft treaty "as in no way adapted to our present circumstances." 28 Indeed, it seems to me that a more plausible conjecture would be, that it was not so much the success of his policy as its comparative failure that may have influenced Shelburne to some extent at this moment. For the draft treaty, like the later Provisional Articles, was to go into effect only when France had also arrived at terms with England. However, the circumstance that really determined the fate of the draft treaty is no mystery. It was the arrival at this moment of the news that Howe had lifted the siege of Gibraltar; and the day following his letter to Oswald, Shelburne also wrote Rayneval

${ }^{25}$ Shelburme to Oswald, Oct. 20 , Fitzmaurice, op. cit., III. 283 . 
that England would not yield Gibraltar to Spain nor St. I ucia and Dominica to France. ${ }^{29}$

Naturally, it would be impossible to determine with minute exactitude the extent to which the United States profited by the action of the commissioners in ignoring their instructions; and yet it is a matter that admits, I think, of rather confident speculation when the two controlling factors of the situation are elearly set forth. 'The first and nore important of these is the hope that was held out to the British eabinet by the independent attitude of the Americans that if the United States were satisfied with the terms they received from England, they would refuse to continue in the war in the interest of Spain. It was because of this hope that the cabinet yielded the Amerieans their demands as to the boundaries and the fisheries, and it is almost inconceivable that they would otherwise have done so. But in the second place, once this concession was ratified, the hands of the British government were tied, and it could neither offer nor demand equivalents within the field of American pretensions." At one point, however, this statement denands qualification, but only with the result of reinforc-

$2011 ., 250$.

" It must be recognized in this comncotion that it was mot only the possibility that England would deny Gibraltar to spain that was dangerons to American interests. For if lingland had given 11) (iibraltar, she would have demanded equivalents, and these might very well have lain wilhin the field of the Smerican pretensions, foe Plillips, op. cit., 210 and Doniol, V. 617. 
ing the principal argument. By the separate and secret article of the Provisional Articles, England retained the right for herself to a northern boundary to $W$ est Florida at the line running due eastward from the mouth of the Yazoo river, but not the right to accord Spain a boundary to the same province north of the thirty-first degree.

The contemporary estimate of the achievement of the conmissioners confirms this analysis most strikingly. The commissioners themselves in communicating the articles to Congress, though somewhat apologetic for the concessions that had finally been made in the interest of the loyalists and the British creditors, used the quiet terms of profound satisfaction: "We can not but flatter ourselves that they [the articles] will appear to Congress as they do to all of us, to be consistent with the honor and interest of the United States."'31 Congress' estimate of the terms was governed in part by the jealousies of sections and factions, but it is to be noted that those who had expected most were most gratified. "Mr. Wolcott," Madison records, "conceived it unnecessary to waste time on the subject" - a proposition to communicate the separate article to the French envoy_-"as he presumed Congress would never so far censure the ministers who had obtained such terms for this country as to disavow their

${ }^{31}$ See their letter to Livingston, Dec. 14, Wharton, VI. 131-3. 
conduct." 'The event proved that Wolcott had judged rightly, for the proposition referred to inever came to a vote. 'The directest testimony, however, is that afforded by the comments of the Foreign Office on the articles:

'You will notice [Vergennes wrote Rayneval] that the En glish buy peace rather than make it. Their concession's indeed, as well in the matter of the boundaries as in that of the fisheries and the loyalists, exceed all that I cou ld have thought possible. ${ }^{33}$

Rayrneval agreed: 'the treaty with America appeared to him a dream, and the English ministers in according it had had in view ultimately the defection of the Americans. ${ }^{34}$

However, it must be remembered that the Provisional Articles were procisional. Indeed, their immediate effect was to diminish the likelihood of peace, by encouraging the British cabinet to set an impossible price upon Gibraltar. ${ }^{35}$ And, of course, had the war been renewed, the Americans

${ }^{32}$ Writings, I. 411. Note Also his statement: "The terms granted to America appeared to Congress on the whole extremely liberal," ib. 403.

Dec. 3, Wharton, V. 293-4; Doniol, V. 188. See also his letter of Jnly 21, 1783, to Ia Iuzerne where he says: "The boundaries in the Mississippi region must have astounded the Americans. Surely they did not flatter themselves that the English ministry would go heyond the mountains that hen in the United States from the Ohio to Georgra," ib., $293-4$.

it Ib., 270.

* $16 ., 224-30$ and 251-6. The equivalent first demanded by England for cibraltar was the French islands, Guadaloupe and Dominica, ib., 220. After the arrival of the news of the American signature St. Iucia was added to the lint; or in its place, Trinity; 
would have had either to part with their winnings or with the French alliance. Aid came from an unexpected quarter. Early in December the Spanish ambassador received a despatch from Madrid, dated November 23rd, in which inquiry was made as to "what considerable advantage Spain could expect from the treaty, if, for any reason," His Catholic Majesty "made the sacrifice of withdrawing from" the engagement created by the Treaty of Aranjuez. On December 5th Aranda placed this despatch before Vergennes, who at once wrote Rayneval, now in London a second time, to offer the abandonment of Gibraltar if Spain were given Minorca and the two Floridas. 'Ten days later came an affirmative response from Rayneval, and Aranda, though without instructions from Madrid, gave his approval. Florida Blanca's wrath when he learned the bold course of his envoy was tremendous, and even Charless III's, chagrin is badly concealed in his letter of January 2nd to Louis sanctioning peace. Vergønnes' delight, on the other hand, was boundless. "I bow before the Sovereign Being," he exclaimed to Aranda, "and return him my heartfelt thanks for His infinite

or for all three, Porto Rico, ib., 256. It seems to me unlikely, however, that Parliarent would have accepted peace if Gibraltar. had been included among the concessions made to England's enemies. As it was, though the peace was accepted, a vote of censure was passed against it in the House of Commons, Parliamentary II istory, XXIII. ce. 514, and 571 . 
wislom, which has disposed the heart and mind of the Catholic king to give up the eession of Gibraltar." 'To Montmorin he expressed himself to like effect: While he would not like to see such diplomatic usage established as that followed on this occasion by the Spanish ambassador. "it is none the less true that we owe peace to his courageous resolution." 3 it

On January 20th preliminary artieles were signed by the representatives of France and Spain on the one hand and of Great Britain on the other. ${ }^{3 i}$ 'The same day Adams and Franklin-Jay being absent from Paris-signed a declaration asserting that the Provisional Articles were not designed to "alter the relation of the United States toward England so long as peace should not be eoncluded between His Most

* François Ronsseau, "Participation de l'Espagne à la Guerre d'Amerique," Renue des Questions historiques, IXXII. 481-9. See also Doniol, V. 33r-tl, and ch. VIII passim. Even after the Gibraltar question was settled, the negotiations were nearly wrecked by England's demand that Dominiea be given her. It the same time there was a strong war party at the French court as well as the British, among the opponents of Vergennes poliey being his own minister of the Marine, Castries, it., 270 . Areording to Forida blanca, at the moment peace was signed a joint French-spanish experdition consisting of seventy ships of the line and 10,000 men was ready to sail for the liest Indies, Coxe's Vemoirs of the rings of spein, III. 31t-6. The uegotiations were finally saved by England's proffer of Tobago and certain concessions in Pondicherey to France in return for Dominica, Doniol, V. ch. VIII.

at Tley will be found in the Parliamentary History, XXIII. $346-54$. 
Christian Majesty and 1 I is Britamnie Majesty" and "repudiating any interpretation of them contrary to this assertion." 'Thus, salys M. Doniol, was "the alliance in some sort renewed." 3 s

In reality. the one entanghing alliance of our history. the indispensable instrument of our deliverance as a nation, was now at an end. 'Ten years and one daly from the promulgation of this declaration Lomis XVI momted the guillotine. One month after that war began between France and England. 'Two months later Washington proclaimed American nentrality. II is action represented the deliberate decision that the most vital interests of the United States would not admit of its adhering to the pledges given in 1778. But indeed. France had long sinee become reconciled to the idea that America was not an available ally. Some six years before Washington and his cabinet determined to cast aside the 'Treaty of Alliance, the French representative at Philadelphial was urging his government to seize $\mathbf{N}$ ow York and $\mathbf{N e w p o r t}$ to prevent the ir falling into the hands of Great Britain in the erent of war. The Foreign Office replied that it had anticipated just such developments, but that it eonsoled itself that France had "never pretended to make Ameriea a useful ally." that she had had "no other end in riew than to deprive Great Britain of that vast continent." $" 3$

$\therefore$ Domiol, Y. ?is and for.

* The calinet of Versitlles to (1)to, the French charges at l'hila- 
delphia, Aug. 30, 178t, Bancroft, Ilistory of the Formation of the Constilution of the l'nited states (N. Y., 1882, 2 vols), 11. 438. The attitude of France toward her American alliance after the War of Independenee lonked primarily toward preventing the restoration of English influcnee. In this connection the following passilges from the Instructions of Montmorin, Vergennes' sueressor, to the count de Mousticr, who becaune the French envoy at Philadelphia in the fall of 1787 , are interesting: Le Conte de Moustier jugera par la qüil devar s'attueher à fortifier les Américains dans les principes qui les ont engagé à sunir à la France: il leur fera sentir pour eet effet, yưils me saturoient avoir d'Mllie plus naturel que lo Roi, tandis quils penvent être certains que l'Angleterre jalouse leur prosjérite, et qu'elle y nuira autant qu'elle en trowvera l' ocasion. . . Ce seroit se tromper volontairement gue fle supposer que cotte puissanee [England] ne cherehe pas à diminuer les sentinents qui doivent attacher les Etats-Unis a la France, et à opérer insensiblement leur rajuochement de leur ancienne Nire-patric. It sera utile que le Ministre du Roi suive la marche des agens anglais, et qu’il fasse ce qui dépendra de lni, mais sans affectation, pour rendre nulles leurs insinuations." "Memoire pour servir d'Instructions au Sieur Comte de Moustier," O't. 10, 1787, American IIistorical Review, VIII. 710-1. Montmorin expected that if war broke out between France and Great Britain "the Americans would wish to remain neutral," and indicated the probability that linance would favor this disposition. However, he continued, "circumslances may counteract our prin(riples," Bancroft, op. rit., 11. 14. A few months later Moustier reported an argmment by Jay to the effect that the Treaty of Alliance no longer sulsisted, to which proposition Montmorin demurred strongly: "I.e Roi et son ronseil, $\mathbb{I}$., ont éte singulierement etomnés de l'opinjon ò est M. Jay que I'Alliance entre le Roj et les Etats-Unis ne sulssiste plus. Ce ministre a dome oublic les termes dans lesquels cotte Alliance a étè conçue: s'il veut hion relire le traité du 6 . février 1778 et se eonvaincre qu'elle: ent perpétuelle. . . Il convient, $\mathbf{M}$, que vons rectificz les idées de MI. Jay sur ces différents objets: vous lassurerez que le Rol regarde son alliance avere les litats-l'nis comme inaltérable; que Sa. M'té. a toujonrs pris et qu'elle ne cessera de prendre an intérêt véritable

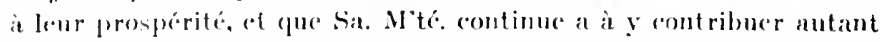
quille Ie pourra sans préjuclice à ses propres intérêts. Violà, M., 
la doctrine que vous devez faire germer et que le Conseil du Roi a été surpris de voir si mal établie." Montmorin to Moustier, June 23, 1788, American Historical Reviez, loc. rit., 728. Four ycars later the monarchy gave place to the republic and Genêt came to the United States. His "Instructions d'Arrivée" contained an interesting attack on the "Machiavellism" of Vergennes' policy toward America, the basis of the charge being the former minister's opposition to American acquisition of Canada; and the implication was that the new government would be controlled by mucl more liberal principles. Annual Report of the American Historical Association for 1903, I I. 202-3. At the same time Genet was instructed to get a new treaty with the United States extending the articles with reference to commerce and navigation, "as the just price of the independence which France won for the United States," and renewing the guaranty of the Treaty of Alliance of French possessions in the West Indies. Ib., 207-11. Both the Treaty of Amity and Commerce and the Treaty of Alliance were declared "void" by the Senate on June 25,1798 , and by the House of Representatives on July 7 . This action of the Houses was posited on the right of Congress to judge of infractions of the Law of $\mathrm{Na-}$ tions, Annals of Congress, 5th Congress, I. 586-8, II. 2116-28. 


\section{CHAP'TER XVI}

\section{PROFIT AND LOSS}

In the ensuing chapter I shall discuss the outcome of French intervention in the War of Independence from the point of view of the objective of that enterprise. The treaty of peace between France and England throws little light on the subject, albeit France obtained some minor adrantages by it, an island in the West Indies which she had lost in 1763, a strip of land on the West African coast, an enlargement of her fishing rights in Newfoundland, the suppression of the articles relative to Dunkirk. The treaty is significant rather as a symbol. England, exhausted by the war, "had not blushed to be the first to petition for peace," and the treaty itself had "erased the stain" of 1763. Thus Vergemnes writes in his Mémoire to the King, of March 29th, 1784, where, moreover, he presents the treaty as the consummation of a period of conspicuous triumph for his entire system. ${ }^{1}$

Louis, the minister records, had ruled but a decade, yet within that brief period he had re-

'Ségur, Politique de Tous les Cabinets, III. 196-219. 
stored peace to Europe no fewer than four times. In Germany by the 'Treaties of 'Teschen he had vindicated afresh France's prerogative as guarantor of the Treaty of Westphalia. Twice in the Southeast he had rescued Turkey, at the cost to that power of some small subtractions of territory, from the clutch of its enemies. Meanwhile, the transparent disinterestedness of His Majesty's principles had won the confidence of Europe, so that all nations had been content to see him "lower the pride of England and labor for her enfeeblement." In brief, France was once more what she had been, "the moderator and arbiter" of Europe, the power that "gave the tone" to the European concert. "Placed in the center of Europe, strong by virtue of the contiguity and unity of her provinces, and by the wealth and population of her soil," girt round by protecting fortresses and by neighbors mutually isolated, she was free to forego aggrandizement and to devote all her influence "to the preservation of the established order and to preventing the different states which compose the European balance from being destroyed."

Over against this chant of victory and accentuating its triumphal note, stand the contemporary lamentations of Englishmen at the downfall of Britain throngh the loss of her American empire.

\footnotetext{
${ }^{2} 16 . .201$.

${ }^{3}$ Loc. rit. See also p. 218.
} 
"The greatest statesmen whom England had produced." writes Wraxall of this period, "though they concurred in scarcely any other political opinion, yet anreed on the point that, with the defalcation of the 'Thirteen Colonies from the crown, the glory and greatness of Britain were permanently extinguished." + The Parliamentary debates support his assertion. "Are we," Burke caustically inquired in his speech on the address from the throne following the reeeipt of the news of Yorktown.

are we to be told of the rights for which we went to war? Oh, excellent rights! Oh, valuable rights... that have cost England thirteen provinces, four islands, 100,000 men, and seventy millions of money! Oh, wonderful rights, that have lost to Great Britain her empire on the ocean, her boasted, grand, and substantial superiority which made the world bend before her! Oh, inestimable rights, that have taken from us our rank among nations, our importance abroad, and our happiness at home: and that have taken from us our trade, our manufactures, and our commerce: that have reduced us from the most flourishing empire in the world to one of the most unenviable powers on the face of the globe !"

The same sentiment was voiced on one oceasion or other by men of all parties, by Lord George Germaine, North's minister of WVar, who maintained that "from the instant when

'Historimal Memoirs (Phila., Is45), 366.

"Parliamentary History, XXII. col. T?l. 
American independence should be acknowledged the British empire was ruined"; "by Sir John Cavendish of the Whig opposition, who declared that "the great and splendid empire of Britain was nearly overturned" ; ${ }^{7}$ by Shelburne, who asserted that "whenever the British Parliament should recognize the sovereignty of the 'Thirteen Colonies, the sun of England's glory was forever set." A writer in the Gentleman's Magazine, commenting on Great Britain's "astonishing decline" "from being the first maritime power in the world," accounted for it in the following strain of philosophic resignation:

In these vicissitudes the hand of Providence, by which the government of the world is directed, is most manifest. Nations and peoples are permitted to arrive at a certain pitch of greatness, and when at the height are doomed to fall to decay. None of the great monarchies of ancient time, so celebrated in history, nor even the Republic of Rome itself, were ever in possession of half the territory which Great Britain could boast at the commencement of the reign of George III. By its so suddenly crumbling to pieces, part after part, does it not seem that this is a devoted Empire? ${ }^{9}$

- Wraxall, op. cit., 367.

"Parliamentary History, XXII. col. 1114.

${ }^{8}$ Same as note 6 . And see generally the debates on the treaties, Parliamentary History, XXIII. cols. 373-571.

${ }^{9}$ Vol. L.II. 123. See also John Adams to Vergennes, July 13, 1780: "Breaking off such a nation as this [America] from the English so suddenly and uniting it so closely with France is one of the most extraordinary events that ever haplened among mankind," Wharton, III. 855. 
And not only had Britain declined: by the same token France had beeme predominant once more. 'The dominion of America, a 'Tory writer had urged shortly before Cornwallis' surrender, gave dominion of the seas, and France's calculations had proceeded from this postulate: "The balance of power which has from the beginning of the reign of Charles $\mathrm{V}$ been so diligently studied in every part of Europe as a science, and which is now brought to a degree of improvement unknown to the rustieity of former ages, could not but obtrude itself in her councils."10 "What," inquired the learned Dr. Fothergill, in an "Address" to his eountrymen, some months later, "can France gain by all these expenses if she seeks not for territorial possessions in America?" and answered his own question thus:

Why, the uncontrolled superiority in Europe. For, where is the power, when America is divided from us, that can withstand her? Whilst we had America France knew, and all Europe felt, that every distant possension they had were so many obligations for her peaceable belaviour. They saw America growing so populous and so powerful, her commerce increasing and increasing the power of Great Britain, that nothing was secure from us. ${ }^{11}$

Riringlon's Royal Gazette (New York), Sept. 29 and Oct. 3, 1701 .

${ }^{11}$ Quoted in the Boston Evening Post and General Advertiser of lech. 23, 1782. The learned doctor continued that, "by the people of New England only. New Spain would have been added to the British Enpire in a few years with the succour of the 


\section{"Happy would it be for us," exclaimed another writer,}

if the loss of America was the only evil we have this day to deplore. The independence of that country is so great an object with the different nations of Europe that we have armed nearly one-half of them in its favor. . . The influence of France in the course of this war has risen to such a pitch that renders it almost a degree of vanity in us to call her any longer the rival of this comtry. She has occupied its place in foreign courts and has become in a few years the arbiter of Europe. ${ }^{12}$

Even as late as the end of $\mathbf{1 7 8 2}$, we find a writer declaring in the London Chronicle, that the people of Great Britain were

ready to part with an eighth or a quarter of all they are worth rather than accede to the independence of America and suffer so disgraceful and ruinons a dismemberment of the empire, which must in its consequences give to France the dominion and commerce of the European seas and render Great Britain the least significant among nations. ${ }^{13}$

British fleet, and France knew that her West Indian islands were held by them at our courtesy should a war break out."

${ }^{13}$ Quoted ib., in issue of Mar. 9, 1782. See also the London General Advertiser of Mar. 6, 1782, where the following sentiments appear: "To how infamous and degraded a situation are we reduced!... What a contrast is the king of lerance! He is without donbt, not only the first monarch of his time, but the wisest, greatest, and best of monarchs that ever sat upon any throne!"

${ }^{13}$ I ondon Morning Chronicle, Nov. 30 and Dec. 5 and 11, 1789. 
'The common sense of mankind has pilloried in mumerous disdainful maxims that odious species of wisdom which parades itself after the event. And yet if the historian is to be wise, qua historian, it must he after the event. The testimony we have just reviewed goes far to stamp Vergennes' policy with the sanction of the statesmanship of that generation. Indeed, the very stubbornness with which England had resisted American independence implies the same thing. We of tolay, however, easily see that the French program, precisely as it was dedueed from certain premises, rested upon too restricted a foundation of fact, that its results were neither solid nor durable, and that, trifling as they were, they were obtained at suicidal cost. Nor is this altogether the wisdom of the autopsy. Vergennes himself betrayed no little disappointment in the outcome of his labors.

'The first respect in which the course of events cheated the calculations underlying French intervention in the $\mathbf{W}$ ar of Independence was the swift recuperation of England from her losses. For this phenomenon, which, he asserts, had "no parallel in the history of the world," Wraxall adduces three causes: "the preservation of the British Constitution": the institution of the sinking fund by Pitt: and the extension of British acquisitions in India, whence an annual revenue of fifteen millions sterling, payable in specie, was 
soon drawn. ${ }^{14}$ The last two causes were no doubt potent, but they coöperated with still more powerful ones, the rise of the factory system at this same period and the opening up of England's mineral resources. In these circumstances, the fact upon which perhaps more than any other England's enemies had counted to produce her downfall, became a blessing in disguise, the public debt. Stabilized by Pitt's measures, the famous "consols" rendered British resources fluid and turned them into the channels of trade and industry as nothing else could have done.

Still it may be urged that these developments would have occurred anyway and that the loss of America contributed to off set them. Is this so? Vergemnes' purpose was to break down both the political and the commercial connection between England and America, and so far as the former was concerned his success was unquestionable. Not only was the aid which France lent America the efficient cause of the outcome of the war, but the sentiment of gratitude which this aid engendered among the American people at large was a factor of no little importance in weaning the country from its natural predilection for the former mother-land. ${ }^{15}$ As we have seen, the al-

${ }^{14}$ Op. cit., $36 \%-71$.

${ }^{15}$ For a very pessimistic aecount, from the French point of view, of the Ameriean propension for things English and the English themselves, despite the war, see a letter from Kalb to Brogrie, gloted in Doniol, IV. 19 fn. This letter was probably 


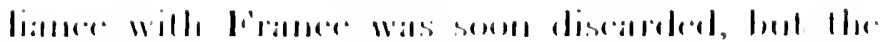

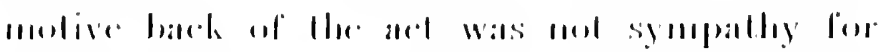

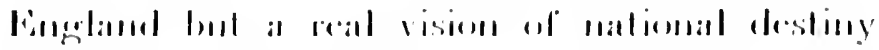

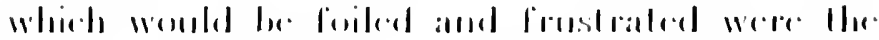

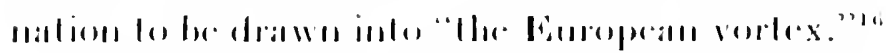

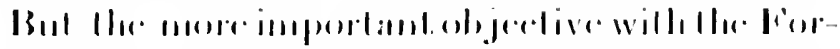

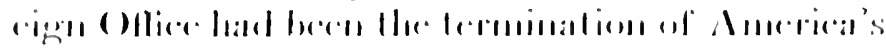

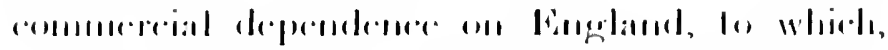

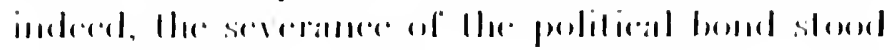

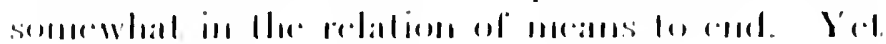

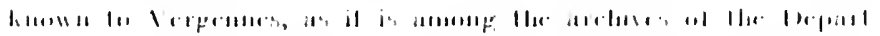

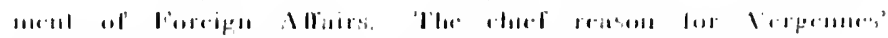

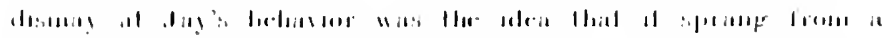

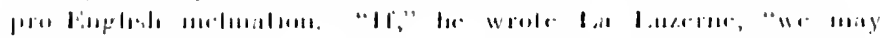

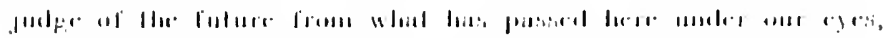

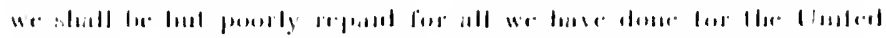

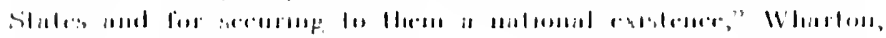

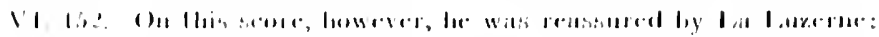

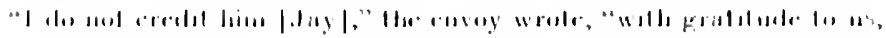

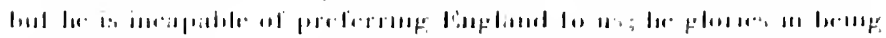

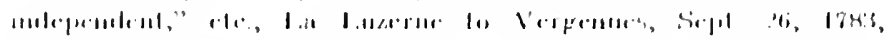

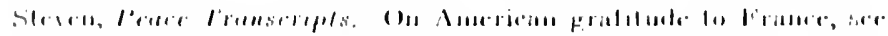

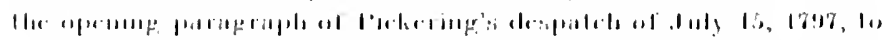

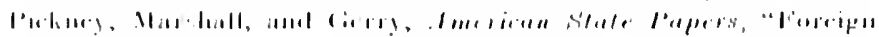

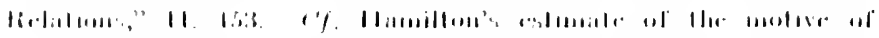

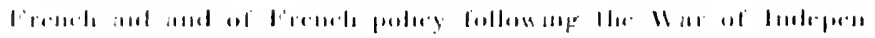

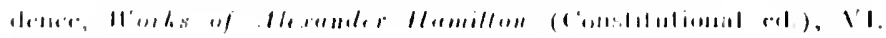
?hi 11 .

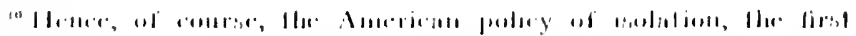

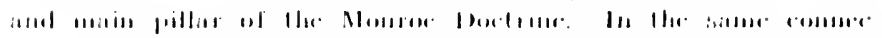

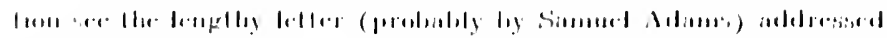

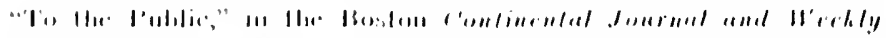

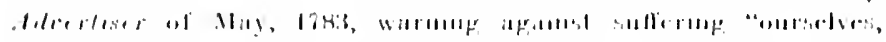

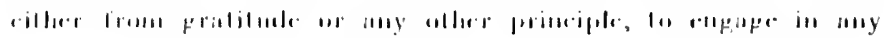

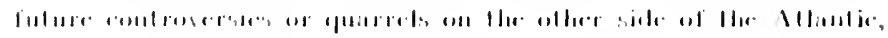

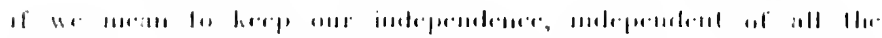

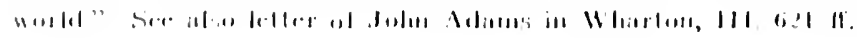


it is at this point exactly that Vergennes' reckoning, which, like that of his alarmed English contemporaries, was based on the teachings of Mercantilism, went most awry. The peace negotiations had not yet begun when his auxiliary, Dupont, wrote Hutton, early in 1782, that "if the war is not too long continued, the Americans will be more to England than to us, since the language they speak and their former relations will naturally lead them to carry on trade with the English rather than with France." ${ }_{17}$ To be sure, it does not appear whether Dupont, who was a

${ }^{7}$ Doniol, V. 36-7 fn. It would seem that there was considerable trade between England and America even while the war was still in progress. "This," writes Adams to the President of Congress, June 26, 1781, "is a subject which deserves the serious consideration of every American. British manufactures are going in vast quantities to America from Holland, the Austrian Flanders, France, and Sweden, as well as by the way of New York and Charleston, etc.," Wharton, IV. 521. For a Congressional ordinance designed to check this trade, see Journals of Congress, Dec. 4, 1781, XXI. 1152. For some evidence of England's rapid recovery of her American trade after the Revolution, see Moustier to Montmorin, Feb. 8, 1788, American Historical Reriew, VIII. 716, where the writer complains that the Americans use the monetary proceeds of their trade with the French islands to pay for the merehandise which they import from England; also Baring's Inquiry into the Causes and Consequences of the Orders in Council (Iondon, 1808), pp. $19 \mathrm{ff}$. As to French commerce with the United States, see a pamphlet in the Pennsylvania Historical Society's library entitled Causes qui se sont opposées au Progrès du 'ommerce entre la France et les Etats-Unis (Paris, 1790). Franklin's hope was to see the United States become commercially independent of Europe, Lee's Lee, I. 354. 
disciple of Quesnay, expressed in the passage just quoted the views of his superior. But the commercial treaty which he negotiated with England early in 1786 affords unmistakable evidence that Vergennes' own economic creed had undergone considerable change since the date of the Exposć Succinct. ${ }^{1 s}$ Even earlier, moreover, he had recorded his recognition of the fact that American independence had not touched the vital sources of British sea-power. In the memoir of March 29th, 1784, while asserting that France had recovered her influence on the Continent, he warned the king that the English fleet would soon be "more numerous and more powerful than it was at the moment of peace," and that the only guaranty of continued good relations with that country was the maintenance of the French marine on a respectable footing. ${ }^{19}$

At this point, however, it behooves us to remember that in Vergennes' thinking the crippling of English sea-power was to be contributory to a far more important end, the restoration of French leadership on the Continent and the establishment

${ }^{19}$ This treaty aholished or lowered many protective duties between the two countries, French wines thus obtaining entry to the English market in competition with Portuguese, and English mauufactures being almitled to the French market. The treaty was a distinct triumph for the views of Adam Smith and the French Ihysiocrats. For contemporary diseussion of its provisions, see Annual Register, XXIX. 65 ff.

19 Ségnr, III. 217-8. 
there of a reign of peace. Unhappily, this dream - for it was little more-was based on the tradition of a Europe that no longer existed, of a Europe in which Poland, Sweden, and Turkey were still effective units of the balance of power; in which Prussia was still dependent on France; in which the House of Austria was definitely secondary to the House of Bourbon; in which Russia had no voice. Once again, in other words, had the minister premitted the conventional creed of his office to blind him to the actual facts; and once again, in consequence, is he forced to record his own disillusionment. "What had rendered peace so necessary" the year before, he informs us in the document just cited, was "the swift rapprochement" of "the courts of Vienna and St. Petersburg, which for twenty years had dwelt in open enmity." It was, he continues, a development "calculated to arouse disquiet and alarm"; and indeed, his whole tone reveals his own most serious concern. ${ }^{20} \quad$ Yet it is difficult to see how, even if the outcome of the war had been the total annihilation of British sea-power, France would have been in any better position to deal with this formidable and unprecedented combination in the Southeast. $^{21}$

${ }^{20} \mathrm{Ib}$., $203 \mathrm{ff}$.

${ }^{21}$ In this connection it should be recalled that in $\mathbf{1 7 7 4}$ Vergennes had considered the feasibility of an Anglo-French rapprochement directed against Russia, See chapter III, supra. After the war Shelburne propounded the same idea to Rayneval. 
In a word, the restoration of French prestige had altered the actual balance of forces on the Continent very little, if at all; and by the same sign, it had gone but little way toward guaranteeing the status quo or a lasting peace. Vergennes' own recognition of this unpleasant truth was as frank as possible: 'It was difficult to flatter one's self of a long peace or even to regard the existing one as more than precarious, unless the power to which alone it belonged to give the tone found itself in position to make itself respected.' This was France's "superb prerogative"; but "good example would not of itself suffice, were it not backed up by imposing means.' 'Of all human passions, ambition was the most active, the one held in leash with greatest difficulty. Defect of power alone could render it passive; and this could exist only if His Majesty was ready and willing to repell all designs on the

Not only, said the former, were France and England not natural enemies but they had many interests in common which onght to cause them to come to an understanding. There had been a time when no one dared set off a cannon in Europe without the consent of England and France, while today the powers of the North assumed to stand by themselves. "Let us unite and we shall give the law to Europe." Certainly, they were too clear-sighted in France not to be convinced that the system of the German empire was an unnatural one, and that Russia wished to enjoy a rôle and had views which were not harmonious with the interests of France and England. "If we are in accord we shall take onr old place once more and shall be able to arrest all revolutions in Europe," etc. Rayneval's Report of his Second Mission to England, Doniol, V. 619-20. 
public security and tranquility.' "Force is the surest measure of respect, particularly when it is exercised with wisdom and employed with justice."22

In 1785 Vergennes scored his last great diplomatic triumph, a settlement of difficulties between the emperor and Holland and a close offensive and defensive alliance between the latter power and France. "The Count de Vergennes," commented the writer in the Annual Register, this year

acquired the honor to his country and the glorious distinction to himself of being the pacificator general of the universe. It could not but be a grevious consideration to Englishmen that, while France, through the happiness of great ministers at home and their choice of able negotiators abroad, was spreading her consequence and extending her influence through the nations of the earth, Great Britain through some unaccountable fatality seemed to be fallen from that high seat in which she had so long and so gloriously presided and to be no longer considered . . . in the general politics and system of Europe. ${ }^{23}$

In fact, the triumph, resting as it did on the unstable basis of the temporary preponderance of the Duteh Republican party, was for France an empty onc. Within a few months the House of Orange, s tively backed by Pitt, was again in control, and France was signing a declaration

${ }^{22}$ Ségur, III. ? ir-s.

${ }^{23} \mathrm{Ib}$., XXVIl. :37. 
"agreeing to a general disamament and asserting that the king of Flance had never any intention of interfering in the affairs of the Dutch Republic." "France," said the emperor maliciously, "has just fallen. I doubt if she will ever reeover."

The words were prophetic, more prophetic than their author could willingly have intended them to be. 'There were others, however, who had already begun to perceive how unreal France's trimimph over England had been and, on the other hand, how terribly real its cost was like to prove. One of these was Burke, who in the Annual Register for 1787 wrote as follows:

It seemed a grand stroke of policy to reduce the power and humble the pride of a great and haughty rival. . . Nor was this all; for as it was universally supposed that the loss of America would prove an incurable, if not a mortal wound to England, so it was equally expected that the power of the Gallic throne would thereby be fixed on such a permanent foundations as never again to be shaken by any stroke of fortune. . . This speculation, like many others, when tried by the test of dear-hought experience, came to nothing, and their fond hopes have already vanished in smoke. . B. But though the American war failed in producing its wished for effects in respect to France, it left behind it other relies of a less pleasing nature. An immense new debt, being laid upon the back of the old,

24 Ilassall, The Baloure of Potcer, p. 379, citing Marquis de Barral-Montferrat, Di.r Ans de Petid armite entre la France ot l'Angleterre, $1 \% 83-9 \%$. I. 54. 
already too great, the accumulation became so vast . . . as to exceed all inquiry." "And as the minds of men grow attached to those principles which they are embarked in require them to maintain ... , the French nation, resorting more to provision and principle by which the abuses of power are corrected than those by which its energy is maintained, have imbibed a love of freedom nearly incompatible with royalty. ${ }^{25}$

Seldom indeed has the course of events displayed a more ironical, yet juster logic, than that whereby the last considerable achievement of the Classical diplomacy - an achievement that had been planned to secure Europe peace and repose for many years-had within a decade become the funeral pyre of the Old Régimé and the startingpoint of a conflagration more than Continental.

Early this same year Vergennes died, just as the Assembly of Notables was convening to make a last effort to rescue the monarchy from bankruptcy without at the same time invading prescriptive rights. So his passing was synchronous with the passing of the order on whose outworn ideals and outlook he had reared his whole ambitious and mistaken structure. Yet the temper of his purpose was something more permanent; for the cold sophistry of the diplomat enwrapped the ardor of the patriot, as witness the words in which he shaped, for the last time as it seems, an apology for his American venture:

${ }^{25}$ Annwal Register, XXIX. 174-s. 
A nation [he wrote] ean experience reverses, and it ought to yield to the imperious law of necessity and its own preservation; but when such reverses and the humiliation they entail are unjust, when they have for their end the gratification of the pride of a powerful rival, then the nation owes it to its own honor, dignity, and self respect, to retrieve itself when occasion offers. If it neglects to do so, if fear holds it back from duty, it adds abasement to humiliation and becomes the object of contempt of its own age and of ages to come. These important truths, Sire, have never been absent from ny thoughts. They were already deeply graven on $\mathrm{my}$ heart when Your Majesty called me to His Couneil, and I awaited with lively impatience the opportunity of following their lead. These are the thoughts that fixed my attention on the Americans, that made me watch for and seize the moment when Your Majesty could assist that oppressed people with a well-founded hope of effectuating their deliverance. If I had had other sentiments, other principles, other views, I should have betrayed your confidence and the interests of the State; I should regard myself as unworthy of serving Your Majesty, I should regard myself as unworthy the name of Frenchman. ${ }^{26}$

Doniol, I. 3-t. 



\section{BIBLIOGRAPHICAL NO'TE}

My principal source has been the material from the Archives of the French Department of Foreign Affairs to be found in Henri Doniol's IIistoire de la Participation de la France à l'Etablissement des Ltats-Unis d'Amérique, Correspondance Diplomatique et Documents, a work in five large quarto volumes, containing some four thousand pages, and in process of publieation for fifteen years (1884-99). The work embodies four sorts of text: first, the author's narrative, which is in large type and is frequently a rumning paraphrase of documentary material; seeondly, documentary material in small type set in the narrative; thirdly, footnotes in fine type containing further documentary material and the referenees to the Archives; fourthly, documentary appendices to the individual chapters in small type. The proportion of purely documentary material to the author's narrative may be illustrated from volume II, which is fairly illustrative of the set. 'This volume contains 864 pages, of which the extracts from documents fill better than 580 pages, printed in small and fine type. Making the proper allowance for the different sizes of type, I caleulate that nearly, if not quite. four-fifths of the material in these 
volumes is source material. Nor can there be any doubt as to the thoroughly representative character of this material; indeed, its essential completeness. Primarily, of course, I base this conclusion upon my perusal of the work, but I am confirmed in it by the examination of such works as the Stevens Facsimiles, Circourt's Histoire de l'Action Commune, and Mr. Phillips' scholarly essay on The West in the Diplomacy of the American Revolution. It may be confidently asserted that conclusions which are securely based on the material in Doniol can only be confirmed by further research in the Archives. Conversely, for an American student, with limited time at his disposal, to attempt an investigation of the Archives without a thorough acquaintance with Doniol to begin with, would be deliberately to incur the risk of one-sided and ill-considered, however surprising, results.

But, of course, there are certain phases of the subject of French intervention in the War of Independence with which Doniol does not pretend to deal, while on the phases with which he does deal he throws, for the most part, only the light shed by the French correspondence. Thus he ignores altogether the background afforded the subject by the history of eighteenth century French diplomacy, and by Choiseul's attitude toward the initial phases of the British-American dispute. To sketch in this background is, 
accordingly, the purpose of the first two chapters of the present volume, with which should also be grouped the last chapter. The material there used, of which the most important items are the voluminous Recucil des Instructions, the elder Ségur's Politique de Tous les Cabinets, De Witt's Thomas Jefferson, Soulange-Bodin's Pacte de F'amille, Bourguet's Duc de Choisenl et l'Alliance Espagnole, Flassan's Histoire Génćrale et Raisonnée de la Diplomatic Française, and various memoirs, is cited in the footnotes with full bibliographical data, which need not be repeated here.

It is also valuable, particularly in connection with the dealings of the French envoys with the Continental Congress and with the final Peace Negotiations, to supplement the French material from the American sources. These are to be found principally in Wharton's great work and the Journals of the Continental Congress, both of which have been thoroughly utilized in the present volume. In the same comnection, I had also previously gone through a large mass of newspaper material, but my gleanings from this have turned out to be of use only to illustrate public opinion at times. Finally, of the writings of American public men of the period, those of Jay, Madison, Charles 'Thomson, the secretary of Congress, and Deane have proved to be of most value. 
Hardly less important, however, than the American aspect of French intervention is the Spanish phase, and for that I have had to rely again principally on Doniol; but for a reason stated in the text, this is hardly matter for regret, for as I point out, the Spanish ambassador at Paris throughout the Revolution, the Count d'Aranda, did not enjoy the confidence of his government, with the result that the FrenchSpanish negotiations were conducted almost exclusively through the French ambassador at Madrid, the despatches to whom and the reports from whom are given by Doniol with his usual thoroughness. Only at two points, and those bearing only remotely on the subject of this volume, is it possible that the Spanish archives might prove of material value. Thus, in connection with the Spanish mediation of 1778 it would be interesting to have the correspondence between Florida Blanca and Almodovar, the Spanish ambassador at London; while in connection with Cumberland's secret mission to Spain in 1780, there may be Spanish material that would clarify Florida Blanca's rather ambiguous attitude at this period. But for the most part, it is clear, that the Spanish material touching the subject of French intervention is of negligible worth, a conclusion which is well borne out by such portions of this material as are to be found in the Sparks Mss. in the Harvard University Library. 
Lastly, there are points at which the English point of riew is of importance in connection with the theme of this rolume. In such cases, for the Parliamentary debates I have used the Parliamentary History; as a record of English public opinion and a repository of public documents, the Anmual Register; for the correspondence of the British government with its ambassador at Paris and the reports of British spies, the Stevens Facsimiles; and for material bearing on the final Peace negotiations, the Pcace Transcripts. also compiled by Stevens and now in the Library of Congress.

For further data bearing on the works just mentioned, as well as on the numerous lesser works, pamphlets, articles in periodicals, etc., that were also used in the preparation of the present volume, the reader is referred to the footnotes. 



\title{
APPENDICES
}

\author{
I \\ (a) \\ TREATY OF ALLIANCE,
}

concluded at Paris, Feloruary 6, 1778 ; ratilied by Congress May 4, 1778.

\section{Articles}

I. Alliance against Great Britain.

II. Independence of the United States.

III. Efforts to be made against Great Britain.

IV. Concurrent operations.

V. C'onquests to belong to United States.

VI. Redinquishment of territory by France.

VII. ('onquests to belong to France.

VIII. Islands in Gulf of Mexico.

IX. Renunciation of Claims.

$X$. Powers invited to accede to alliance.

XI. Proprictary rights.

XII. Duration.

XIII. Ratification.

The Most Christian King and the United States of North Ancrica, to wit: New Hampshire, Massachusett, Bay, Rhode Island, Comnecticut, New York, New Jerney, Pennsylvania, Dolaware, Maryland, Virginia, North ('arolina, South Carolina, and Georgia, having this day concluded a treaty of amity and commerce, for the reciprocal advantage of their subjects and citizens,

${ }^{1}$ Text from Wm. Malloy, Treaties, Conentions, ete. (Washington, 1910). 
have thought it necessary to take into consideration the means of strengthening those engagements, and of rendering them useful to the safety and tranquility of the two parties; particularly in case Great Britain, in resentment of that connection and of the good correspondence which is the object of the said treaty, should break the peace with France, either by direct hostilities or by hindering her commerce and navigation in a manner contrary to the rights of nations, and the peace subsisting between the two Crowns. And His Majesty and the said United States, having resolved in that case to join their councils and efforts against the enterprises of their common enemy, the respective Plenipotentiaries impowered to concert the clauses and conditions proper to fulfil the said intentions, have, after the most mature deliberation, concluded and determined on the following articles :

\section{Article I}

If war should break out between France and Great Britain during the continuance of the present war between the United States and England, His Majesty and the said United States shall make it a common cause and aid each other mutually with their good offices, their counsels and their forces, according to the exigence of conjunctures, as becomes good and faithful allies.

\section{Article II}

The essential and direct end of the present defensive alliance is to maintain effectually the liberty, sovereignty, and independence absolute and unlimited, of the said United States, as well in matters of government as of commerce.

\section{Article III}

The two contracting parties shall each on its own part, and in the manner it may judge most proper, 
make all the efforts in its power against their common enemy, in order to attain the end proposed.

\section{Article IV}

The contracting parties agree that in case either of them should form any particular enterprise in which the concurrence of the other may be desired, the party whose concurrence is desired, shall readily, and with good faith, join to act in concert for that purpose, as far as cireumstances and its own particular situation will permit: and in that case, they shall regulate, by a particular convention, the quantity and kind of succor to be furnished, and the time and manner of its being brought into action, as well as the advantages which are to be its compensation.

\section{Article $V$}

If the Cnited States should think fit to attempt the reduction of the British power, remaining in the northern parts of America, or the islands of Bermudas, those countries or islands, in case of success, shall be confederated with or dependant upon the said United States.

\section{Article VI}

The Most Christian King renounces forever the possession of the islands of Bermudas, as well as of any part of the continent of Nortl America, which before the treaty of Paris in 1763 , or in virtue of that treaty, were acknowledged to belong to the Crown of Great Britain, or to the United States, heretofore called British colonies, or which are at this time, or have lately been under the power of the King and crown of Great Britain.

\section{Articte VII}

If Mis Most Christian Majesty shall think proper to 
attack any of the islands situated in the Gulph of Mexico, or near that Gulph, which are at present under the power of Great Britain, all the said isles, in case of success, shall appertain to the Crown of France.

\section{Article VIII}

Neither of the two parties shall conclude either truce or peace with Great Britain without the formal consent of the other first obtained; and they mutually engage not to lay down their arms until the independence of the United States shall have been formally or tacitly assured by the treaty or treaties that shall terminate the war.

\section{Article IX}

The contracting parties declare, that being resolved to fulfil each on its own part the clauses and conditions of the present treaty of alliance, according to its own power and circumstances, there shall be no after claim of compensation on one side or the other, whatever may be the event of the war.

\section{Article $\mathbf{X}$}

The Most Christian King and the United States agree to invite or admit other powers who may have received injuries from England, to make common cause with them, and to accede to the present alliance, under such conditions as shall be freely agreed to and settled between all the parties.

\section{Article XI}

The two parties guarantee mutually from the present time and forever against all other powers, to wit: The United States to His Most Christian Majesty, the present possessions of the Crown of France in America, as well as those which it may acquire by the future 
treaty of peace: And His Most Christian Majesty guarantees on his part to the United States their liberty, sovereignty and independence, absolute and unlimited, as well in matters of government as commerce, and also their possessions, and the additions or conquests that their confederation may obtain during the war, from any of the dominions now, or heretofore possessed by Great Britain in North America, conformable to the 5th and 6th articles above written, the whole as their possessions shall be fixed and assured to the said States, at the moment of the cessation of their present war with England.

\section{Article XII}

In order to fix more precisely the sense and application of the preceding article, the contracting parties declare, that in case of a rupture between France and England the reciprocal guarantee declared in the said article shall have its full force and effect the moment such war shall break out; and if such rupture shall not take place, the mutual obligations of the said guarantee shall not commence until the moment of the cessation of the present war between the United States and England shall have ascertained their possessions.

\section{Article XIII}

'The present treaty shall be ratified on both sides, and the ratifications shall be exchanged in the space of six months, or sooner if possible.

In faith whereof the respective Plenipotentiaries, to wit: On the part of the Most Christian King, Conrad Alexander Gérard, Royal Syndic of the city of Strasbourgh, and Secretary of His Majesty's Council of State; and on the part of the United States, Benjamin Franklin, Deputy to the General Congress from the State of Pennsylvania, and President of the Convention 
of the same State, Silas Deane, heretofore Deputy from the State of Connecticut, and Arthur Lee, Councellor at Law, have signed the above articles both in the French and English languages, declaring, nevertheless, that the present treaty was originally composed and concluded in the French language, and they have hereunto affixed their seals.

Done at Paris, this sixth day of February, one thousand seven hundred and seventy-eight.

(Seal.)

(Seal.)

(Seal.)

(Seal.)
C. A. Gerard.

B. Franklin.

Silas Deane.

Arthur Lee.

\section{(b)}

Act Separate and Secret Reserving Right of King of Spain to Agree to the Foregoing Treaties, concluded February 6, 1778; ratified by the Continental

Congress May \$, 1778, ratifications exchanges at Pàris July 17, 1778.

The most Christian King declared in consequence of the intimate union which subsists between him and the King of Spain, that in concluding with the United States of America this treaty of amity and commerce, and that of eventual and defensive alliance, his Majesty hath intended, and intends, to reserve expressly, as he reserves by this present separate and secret act, to his said Catholick Majesty the power of acceding to the said treatys, and to participate in their stipulations at such time as he shall judge proper. It being well understood, nevertheless, that if any of the stipulations of the said treatys are not agreeable to the King of Spain, His Catholick Majesty may propose other conditions analogous to the principal aim of the alliance 
and conformable to the rules of equality, reciprocity and friendship.

The Deputies of the United States, in the name of their constituents, aceept the present declaration in its full extent, and the Deputy of the said States who is fully impowered to treat with Spain promises to sign, on the first requisition of His Catholic Majesty, the act or acts necessary to communicate to him the stipulations of the treaties above written; and the said Deputy shall endeavor, in good faith, the adjustment of the points in which the King of Spain may propose any alteration conformable to the principles of equality, reciprocity, and the most sincere and perfect amity, he, the said Deputy, not doubting but that the person or pcrsons impower'd by His Catholic Majesty to treat with the United States will do the same with regard to any alterations of the same kind that may be thought necessary by the said Plenipotentiary of the United States.

In faith whereof the respective Plenipotentiaries have signed the present separate and secret article, and affixed to the same their scals.

Done at Paris this sixth day of February, one thousand seven hundred and seventy-eight.
(Scal.)
C. A. Gerard.
(Scal.)
B. Franklin.
(Seal.)
Silas Deane.
(Seal.)
Artulur Leee.

Deputy, Plenipotentiary for France and Spain. 


\section{II}

Reflexions which maY perhaps present some New IDEAS UPON THE GREAT AND IMPORTANT AFFAIRS OF America. ${ }^{1}$

\section{January $177 \%$.}

The arrival of Mr. Franklin in France has given rise to reflections which may perhaps, present some new ideas upon the great and important affairs of America.

The present state of those affairs and the rôle which Mr. Franklin plays therein does not allow an observant person to doubt that this American is deputed to come with eertain propositions to France in the critical position in which his country finds herself of having to achieve absolute independence or of falling again under the rule of England, and even of seeing her position aggravated, if the fortune of war is against her.

If we turn our attention more closely to the true interests of America, of France and of England with regard to this important object, we easily recognize that, in the actual position of things, America has propositions so absolute, so urgent, to make to France, that it is as difficult for her not to come to a decision, as it is essential and pressing for her to determine wisely.

It is not for us, (the writer) supposing that such propositions existed, to go so far as to pronounce upon what it is expedient to do. That point exceeds our province. But one may be justified, as a good subject of the King, and without overstepping the zeal with which one is animated for his service in considering what may be the consequences of the course for or against, to be taken in the circumstances.

One may suppose then that America has at the present time a twofold plan of action demanding equal

${ }^{1}$ Smss. no. 619. Though the work of a "private citizen," this memoir was probably prepared for the Council, Doniol II. 118. 
urgency: either to obtain with the aid of France and spain, her complete independence or to extort an acknowledgment of it from England itself.

The argument which the United Colonies of North America may use to France is to say to her: "Assist us to win our complete liberty and you will derive therefrom honour and advantage by the 'Treaty Offensive and Defensive and that of Commerce which we offer you, or leave us to treat with England at your peril and risk if it is achieved."

On the other hand the proposition which America, to arrive equally at the goal of her independence, may make to lingland is the following:

"We have been fighting," she may say, "for two years past for a rightful liberty. The probabilities for and against, so to speak, are at the present time equal; the issue will become a certainty if we join with France and Spain. Grant us generously what we are in a position to wrest from you, and here is the price we put upon the just independence which we desire. A treaty, as glorious for the mother country as for her colony, being signed, take twenty, thirty thousand men of our troops which are all ready, you have your resiels on our coasts, go possess yourselves therewith of St. Domingo, Martinique, Guadaloupe, drive the French entirely out of America and you will have in the new possessions which you acquire an ample equivalent for what you cede to us; an equivalent more productive. better suited to the nature of your territories, and one henceforward impregnable in your hands because we will be its guardians, its defenders, as well as the nurses of its prosperity, and, being already your brothers by blood and becoming bound to you by a memorable treaty we shall thus be doubly your allies and much more sure allies than if we remained subordinate and discontented subjects." 
If it were permitted to a private citizen to extend his reflections further upon the question of the justice of a war with England in the present conjuncture it might be observed that the war which we may have with that crown, as things stand, would not exactly possess the characteristics of which we have been speaking. It would indeed be rather a war of self-defense, if the propositions of which we have spoken above existed. Indeed, France having the safety of her own possessions compromised has thenceforth only to choose between the course of furnishing America with the aid she asks for or of seeing an oppressed colony or (and) an ambitious mother country treating on their own account and of taking upon herself the consequence of their agreement. If that danger has any foundation in fact, then it is a league prejudicial to her own repose, prejudicial to her possessions, which she breaks. It is a peril which she provides against and averts, and that peril well defined, which politically speaking is most certain, is perhaps a sufficient reason, of justice as much as of state, to warrant a determination of that kind.

Basing our conclusion upon all these reflections as well as upon justice, it remains for us to give our idea of the extent and consequences of the revolution which is preparing, the main object of this writing.

If it is accomplished by our means, it ought while lowering England to raise France in a corresponding degree and restore her to her rank. It may even offer the most fortunate opportunities for making a sure work, secing that England, with her resources already wasted, is almost unguarded at home, and that she presents there and elsewhere opportunities to strike a nearly certain and absolutely decisive blow. Lastly the present conjuncture, a conjuncture which the revo- 
lutions of time so rarely offer, is such that it may hive an influence upon the state of France and upon that of Europe, always to the advantage of this kingdom, which the longest ages will not be able to disturb.

If America is severed from England with our aid, thenceforward all the possessions of that country in that part of the world fall, and ours establish themselves there upon the firmest foundations. Since the two great sources of England's commerce, the sole basis of her fortune, are in America and in Asia, one of the great sinews of that power is thenceforth cut; and if we hasten promptly and effectually to provide for the safety of the Isle of France (a post which can alone preserve India entire and give security to our future projects there) we shall at leisure and at opportunity provide suitably against the excessive power which England is tending to usurp there: in which we shall be the more assisted as the finances of England must needs be thrown completely out of gear by the ill-success of this war; and her public wealth being nothing but an exaggerated and almost artificial credit, she ought to be doubly overthrown both by the expenses of this war and by the loss of her possessions, the only pledge for the truly imaginary credit which has grown up in that nation, and which her constitution, aided by successes, has much favoured.

The consequences of this revolution ought, as we think, to be still more widespread. Such an event in our opinion, changes forthwith, to the advantage of France, the political state of Europe and even repairs the bad effects of the fatal war of Poland which has destroyed the balance of the Germanic body established with so much difficulty by a war of forty years and the celebrated treaty of Westphalia.

England, who weighed too heavily in the contrary balance which produced this change, reduced to her 
natural state, could no longer be of any assistance to Russia and to the King of Prussia, who as yet have only a forced extension of power the unconsolidated fortune of which depends much on the rare qualities of the rulers, who, in spite of their success, have only succeeded in disturbing the equilibrium of Germany without having given it another fixed constitution, since there are two rival monarchies seeking to establish themselves upon the ruin of that aristocracy and a third monarchy, Russia, strives to force a way into it, a state of things which substitutes a conflict or a new war for the old condition of things, the decaying condition of the Germanic body.

It is true that the new house of Austria, by this revolution regains the preponderance in Germany which we had taken away and that naturally she also ought to find in the weakening of England means of increasing her power. But in what respect may France find her interests injured thereby? In their common elevation the point is so strongly in her favour that she has nothing to wish for in that respect. If the maritime power of England falls, France naturally and invincibly takes her place whether by the advancement of her distant acquisitions or by the favourable position of her territories. Her pre-eminence in this respect, too, will be so constant, so certain; besides, the new kind of power which she will acquire is in itself so important, so decisive, considering the present customs of Europe, that it is much rather to be feared this excessive pre-eminence may be noticed and may excite resistance. Consequently, looking at this double increase, the desire of the houses of Bourbon and Austria for union would be better fulfilled by these circumstances than by any others which could ever arise, for, lastly, firm treaties are not formed nor maintained except by mutual advantages. In short nothing can hap- 
pen more essential for France, in her real and in her relative power, than the absolute consummation of this revolution. By her position alone she inherits all that England loses; and without even going so far as to pluck them, she sees drop from the hands of her rival the chief branches of that rival's fortune; all this debris comes of itself to increase her own, and time alone assures her without any effort, a two-fold power, on sea and on land, which she has never been able to unite and which strengthening each other will put her above attack.

Taking now a collective view of this statement of facts all the importance of the resolution which France is called upon to make presents itself to the mind. The question is, according to the laws of nature, as to the liberty of one of the four quarters of the world held eaptive by one of the European powers: in two words, it is a question of giving America to the whole world; politically, it is a question of putting right the state of Europe and chiefly that of France. Finally, if it is permissible in a political memoir to consider the subject philosophically, one can see with some interest a people forming itself into a national body, creating itself a civil state embodying a nixture of the mamners of a state of nature and of the wisdom of an age most fruitful of knowledge, a people which is about to give laws to itself, having before its eyes the laws of all (-ivilized peoples. This is not a collection of savages gradually emerging from barbarism, and which rather receives than gives to itself the constitution which circumstances impose upon it. 'This is a people already' civilized by its understanding and which, after having acquired its political independence, is about to choose for ituelf the legislation that is to establish its destiny for all time. The history of the world perhaps shows no spectacle more interesting, and the political stage 
has never perhaps presented an event the consequences of which are more inportant and more widespread in the general condition of this globe.

Summarizing what has been said in this memoir, the result is that finance must dictate the course to take in the present state of things always after justice shall have spoken. The impression with which one is filled in writing this is such that it cannot too often be repeated that it is a question of taking from England, our natural and actual enemy, more than half her power, and that for ever, and of giving it to France; or of seeing England make an agreement which will give her more strength and cover her with glory, will change into good fortune an occasion of disaster, and all that at our expense; and the course to be taken ought to be taken actively and without delay or it is very possible that the other part of the dilemma just spoken of may be accomplished before our eyes.

The writer here closes the reflections which the fulness of his zeal for the King's service may render acceptable.

\section{III}

Considerations upon the Necessity of France deClaring at once for the American Colonies, even without the Concurrence of Spain. ${ }^{1}$

\section{January 1778.}

The quarrel which exists between England and the Colonies of North America is as important to France as to Great Britain, and its issue will have equal in-

${ }^{1}$ Smss. no. 1835. Though unsigned this document contains expressions from earlier papers from Vergennes' pen. Cf. for example, Doniol, II. 144 and $733 \mathrm{ff}$. Besides the points for which it is cited in the text, the memoir is interesting as an ommium gatherum of all the arguments for French intervention. 
fluence on the reputation and power of those two Crowns. It is, therefore, essential that France should decide upon and fix the policy it is advisable she should adopt in such a conjuncture.

The Americans have been struggling for the last three years against the efforts of Great Britain, and they have up to the present maintained a sort of superiority; but the war which they wage fatigues and exhausts them, and must necessarily weary the people and awaken in them a desire for repose.

England, for her part, crushed by the expenditure occasioned by this same war, and convinced of the intpossibility of reducing the Colonies, is occupied with the means of re-establishing peace. With this view she is taking the most urgent and animated steps with the Deputies from Congress, and it is natural that the United States should at last decide to listen to their proposals.

In this state of affairs it is desirable to examine what course it is proper for France to take.

There exist two courses only, - that of abandoning the Colonies, and that of supporting them.

If we abandon them, England will take advantage of it by making a reconciliation, and in that case she will either preserve her supremacy wholly or partially, or she will gain an ally. Now it is known that she is disposed to sacrifice that supremacy and to propose simply a sort of family compact, that is to say, a league against the House of Bourbon.

The result of this will be that the Amerieans will become our perpetual enemies, and we must expect to see them turn all their efforts against our possessions, and against those of Spain. This is all the more probable as the Colonies, require a direct trade with the sugar islands. England will offer them that of our islands after having conquered them, which will be easy for her. 
Thus the coalition of the English and the Americans will draw after it our expulsion, and probably that of the Spaniards, from the whole of America; it will limit our shipping and our commerce to the European seas only, and even this trade will be at the mercy of English insolence and greed.

It would be a mistake to suppose that the United States will not lend themselves to the proposals of the Court of St. James's. Those States took up arms only in order to establish and defend their independence and the freedom of their commerce; if, therefore, England offers them both, what reason will they have for refusing? Their treaty with that Power will give them more safety than the engagements which they might make with other Powers, or than all the guarantees which we might offer them. Indeed, what opinion can they have of our means, and even of our good-will, since we have not dared to co-operate in securing an independence of which we would afterwards propose the empty guarantee? Their surest guarantee will be in the community of interests and views which will be established between them and their former mother-country; we have nothing to offer which can counterbalance that.

Such will be the effects of the independence of the United States of America, if it is established without our concurrence.

It follows from this that the glory, the dignity and the essential interest of France demand that she should stretch out her hand to those States, and that their independence should be her work.

The advantages which will result are innumerable; we shall humiliate our natural enemy, a perfidious enemy who never knows how to respect either treaties or the right of nations; we shall divert to our profit one of the principal sources of her opulence; we shall shake her power, and reduce her to her real value; we shall 
cxtend our commerce, our shipping, our fisheries; we shall cusure the possession of our islands, and finally, we shall re-establish our reputation, and shall resume amongst the Powers of Europe the place which belongs to us. There would be no end if we wished to detail all these points; it is sufficient to indicate them in order to make their importance felt.

In presupposing that the independence of the Ameri(ans is to be the work of France, it is necessary to examine what line of conduct it is desirable for us to observe in order to attain that end; there is but one,to assint the Colonies.

But in order to determine the sort of assistance to be given, it is essential not to deviate from the two following truths: 1st, that whatever sort of assistance we give the Americans, it will be equivalent to a declaration of war against Great Britain: 2nd that when war is incritable. it is better to be beforehand with one's enemy than to be anticipated by him.

Starting with these two principles, it appears that France cannot be too quick in making with the Americans a treaty of which recognised independence will be the basis, and that she should take her measures for acting before England can anticipate her.

It is all the more urgent to hasten the arrangements to be made with the Americans, as the Deputies are hard pressed by emissaries of the English Ministry, and an. if we are not the first to bind them, they will give the court of London a foundation for proposing a plan of reconciliation at the re-assombly of Parliament, which will take place on the 20th instant, and then all will be over with us, and it will only remain for us to prepare to undertake war against the English and agraint the insurenents, whereas we could and ought to have begun it in concert with the latter. 
In all that has just been said, the co-operation of Spain has been presupposed.

But in the event of that Power not adopting the principles and plan of France, or of her judging the moment of putting it into execution not yet arrived, what course will France, thus isolated, have to follow?

The independence of the Colonies is so important a matter for France, that no other should weaken it, and France must do her utmost to establish it, even if it should cost her some sacrifices; I mean that France must undertake the war for the maintenance of American independence, even if that war should be in other respects disadvantageous. In order to be convinced of this truth, it is only necessary to picture to ourselves what England will be, when she no longer has America.

Thus France must espouse the American cause, and use for that purpose all her power, even if Spain should refuse to join her. From this one of two things will happen; either that Power will still remain neutral, or she will decide to join France. In the first case, although she will be passive, she will nevertheless favour our operations, because she will be armed, and England will see her constantly placed behind us, and ready, if need be, to assist us : but in order to maintain this opinion, we must also maintain that of a good understanding between the two Courts. The second case has no need of development.

But Spain is awaiting a rich fleet from Vera Cruz, and that fleet will not arrive until about next spring. Its arrival must unquestionably be ensured, and that may be done in two ways; 1st by prolonging the period of our operations, or else, 2nd, by sending a squadron to meet the fleet. Spain has vessels at Cadiz and Ferrol; they are armed and ready to put to sea. A cruise might be given as a pretext in order to mask their real destination. 
If the $\mathrm{King}$ adopts the course of going forward without the participation of Spain, he will take away from that Power all just reason for eomplaint, by stipulating for her eventually all the advantages which she would have claimed, had she been a contracting party. These advantages will be the same as those which His Majesty will ask for himself.

\section{IV}

Extracts from the "Observations on the JisticaTIVE Menorial, of tue Court of London."

While the ambassador of England put the King's patience to the strongest proofs . . . an event came to pass in Anerica which essentially changed the face of things in that quarter of the world. This event was the defeat of the army under General Burgoyne. The news of this unexpected disaster... astonished the British ministers, and must have the nore sensibly affected them, as it overthrew the plan they had laid for the reduction of the Colonies. We shall be convinced of this truth by reading the speeches occasioned by it in Parliament. 'The first result of the tumultuous debates of both Houses was the naming of commissioners of peace, to carry to America conciliatory bills; and

${ }^{1}$ The original (though quite different) form of this document is to be found in Beaumarchais' Oeures completes (Paris, 1835), 530-42. The present document was published in Paris in 1779 over Beaumarchais' name, but the edition of 1780 , which is unchanged, is anonymous, though it is attributed in the catalogue of the Bibliotèque Nationale to J. M. Gérard de Rayneval, Vergennes' Secretary. The English-American trauslation (Philadelphia and London, 1780), from which the above extracts are made, is also anonymous. 'I here are four coples of this translation in the Pennsylvania Historical Society's library at Philadelphia, and one of the French edition of 1779 . 
that of the secret deliberations of the council at $S_{2}$. Janes' was to make advances and to sound the American commissioners residing at Paris, and to propose to them peace and a coalition against the Crown of France.

This last proposition was the consequence of the intputations which the ministry of London had incessantiy made against that of Versailles: They have affected to consider France as the cause, the support, in a wori as the author, of the revolution of which America presented them a view; and this opinion would naturally inspire them with the desire of rengeance. . . . This prospect was so much the more proper to console, and even to dazzle the British ministers, as it perfectly corresponded with their most dear and most constant wish, a wish which for a long time had been the very essence of British policy, that of humbling France; and as the presumptuous confidence of that nation must have still grown greater, when they beheld the extraordinary armaments they had got ready, with a despatch which surprised all Europe [the armaments referred to are stated to be those prepared in January, 17\% ] .

The British ministry, led astray by this brilliant phantom, delayed not putting in motion all the secret springs by means of which they would be able to realize it. Emissaries came one after another and watched the American commissioners: Their discourse to every one of them was, that they should no longer continue the dupes of France, but must unite with the court of London, and fall upon that power, etc.

The court of London denies the facts and represents them as a supposition destitute of truth and even of probability, and calls upon France to produce the proof of it. But can a subterfuge like this possibly impose on any one? Who will suspect the British ministry to have carried their want of address or imprudence so far as to leave direct marks of a darksome 
manourre, and of not having on the other hand, taken the most effectual measures that, in case of discovery, it might not be imputed to them! . . . True it is, that according to the British ministry, the King of Great Britain could not be suspected of not being offered peace to his subjects, after a long and hard contest, but with design of entering into a new war against a respectable power; [this is a mistranslation of the French: the second not and the but should be omitted]. But some very plain reflections will make it clear how illusory this affected language is, and how little it deserves belief.

If the court of London . . . either sincerely, or in order to impose upon the English nation or even on its king . . has experienced unpardonable injuries from France, if it has reason for reproaching her with the defection of the Colonies, they must consider her dignity and most essential interests as wounded, and from that time must feel the most ardent desire, not only of taking vengeance, but also of recovering from France what the crown of England lost in Anerica. In consequence of this plan, it was natural for the British ministry, unable to sublue her Colonies, to seek to be reconciled to them and to engage them to espouse her resentment: They might so much the more flatter themselves that they should succeed herein as the proceedings of France with regard to American privateers. . . and especially the dislike the king had at all times manifested to any engagenent with the Congress, must have given disgust and dissatisfaction to their deputies, and induce them, notwithstanding their well known aversion, to seek even in England the safety of their country when they failed to find it in France. . .

In this situation ought it not to be supposed that, the moment the British ministry pereeived the necessity of vielding to the efforts of the ('olonies, they perceived the 
project and the hope of punishing France for the wrongs they had imputed to her? Such have, indeed, been the intention and conduct of the ministers of the king of Great Britain. We have already affirmed, in the Exposé de Motifs and we repeat it here, with that assurance which nothing but truth can give; and the King dares flatter himself that the opinion which all Europe has of his rectitude and probity will have more weight than a denial merely hazarded and which they have not even had the address to render probable.

Moreover, although the king had not had certain proof of the hostile views of the court of London, it would have been sufficient for him to have had probable grounds to suspect that they existed; now, what must His Majesty have thought of the sight of the immense and hasty warlike preparations of the court of London! her arbitrary proceedings, her denials of justice, her arrogant pretensions! What must he have allowed to the last words of the idol and oracle of the British nation, Lord Chatham, who dragged himself to Parliament, there to expire exclaiming, Peace zith America, and war with the House of Bourbon! The court of London herself had justified the suspicion and foresight of the king, by the hostile orders sent to India before the declaration of the Marquis de Noailles, and even before the signing of the Treaty of February 6, 1778....

The King well informed of the plan of the court of London and of the preparations which were the consequence of it, perceived that no more time was to be lost if he would prevent the designs of his enemies: His Majesty determined, therefore, to take into consideration, at length, the overtures of the Congress [pp. 60-6]. 
Whilst the British ambassador renewed without intermission complaints unjust in their object... the British ministry, convinced that notwithstanding their formidable armaments any subjugation whatever of the Colonies was in future jumpossible, proposed to Parliament the means of conciliation; they endeavored at the same time to open a seeret negotiation with the commissioners of congress at Paris: they were disposed to vield werything, even independence in fact, provided they could retain a nominal dependence. But war against France was to be the price of so great a sacrifice. The king apprised on the one side of the offers and hostile views of the court of London, and on the other side of the unshaken resolution of C'ongress not to suffer the least trace of its former subjection to remain: The king, I say, did not hesitate to take a part. . .

To deceive the other nations with regard to the real motives which have directed the conduct of the king, the British ministry maintain that he entered into treaty with the Americans, not because he feared the secret views of Great Britain, but because he foresaw that the Americans defeated, discouraged without support and without resources, were about to return to their mother-country. . . It was without doubt for the sake of this asscrtion that the British ministry have thought it beneath the dignity of their sovereign to search for the period at which France formed connections with the United States. . . . The king is willing to spare the British ministry a task so disagrecable and so embarrasing, by ohserving for them that the conversations which led to the Treaties of the $6 t^{\prime}$ of February, 17\%8, were considerably posterior to the capitulation of General Burgoyne. Now it is notorious that this event elevated the courage and the hopes of the Americans as much as it dejected the British na- 
tion, and principally the court of London. If then the king has listened to the propositions of Congress after this period so disastrous to the British, it has not been, and could not have been for any other reason, but because the thought with the United States that their independence was thenceforward irrevocable; England herself thought as the Americans did" [93-6].

\section{V \\ Provisional Articles ${ }^{1}$}

agreed upon, by and between Richard Oswald, Esquire, The Commissioner of His Britannic Majesty, for Treating of Peace with the Commissioners of the United States of America, in behalf of His Said Majesty on the One Part, and John Adams, Benjamin Franklin, John Jay, and Henry Laurens, Four of the Commissioners of the Said United States for Treating of Peace with the Commissioners of His Said Majesty, on Their Behalf, on the Other Part. To be Inserted in, and to Constitute the Treaty of Peace Proposed to be Concluded Between the Crown of Great Britain and the Said United States; but which Treaty is not to be Concluded until Terms of a Peace Shall Be Agreed Upon Between Great Britain and France, and His Britannic Majesty Shall Be Ready to Conclude Such Treaty Accordingly.

Concluded November 30, 1782. Proclamation ordered by the Continental Congress April 11, 1783.

\section{Articles}

I. Independence acknowledged.

II. Boundaries.

III. Fishery rights.

IV. Recovery of Debts.

V. Restitution of estates.

VI. Confiscations and prosecutions to cease.

VII. Withdrawal of British arnies.

'Text from Malloy. 
VII. Navigation of the Mississippi River.

IX. Restoration of territory.

Separate Article. Boundary of West Florida.

Whereas reciprocal advantages and mutual convenience are found by experience to form the only permanent foundation of peace and friendship between States, it is agreed to form the articles of the proposed treaty on such principles of liberal equity and reciprocity, as that partial adrantages (those seeds of discord) being excluded, such a bencficial and satisfactory interconrse between the two countries may be established as to promise and secure to both perpetual peace and harmony.

\section{Article I}

His Britannic Majesty acknowledges the said United States, viz., New Hampshire, Massachusett's Bay, Rhode Island and Providence Plantations, Connecticut, New York, New Jersey, Pennsylvania, Delaware, Maryland, Virginia, North Carolina, South Carolina, and Georgia, to be free, sovereign and independent States; that he treats with them as such, and for himself, his, heirs and sucessors, relinquishes all claims to the Government, propriety and territorial rights of the same, and every part thereof; and that all disputes which might arise in future on the subject of the boundaries of the said United States may be prevented, it is hereby agreed and dectared that the following are and shall be their boundaries, vi\%:

\section{Articte II}

From the northwest angle of Nova Scotia, viz., that angle which is formed by a line drawn due north from the source of St. ('rois River to the Highlands; along the Highlands which divide those rivers that empty themselves in to the river St. Lawrence, from those which 
fall into the Atlantic Ocean, to the northwesternmost head of Connecticut River; thence down along the middle of that river to the 45th degree of north latitude; from thence, by a line due west on said latitude until it strikes the river Iroquois or Cataraquy; thence along the middle of said river into Lake Ontario, through the middle of said lake until it strikes the communication by water between the lake and Lake Erie; thence along the middle of said communication into Lake Erie, through the middle of said lake untill it arrives at the water communication between that lake and Lake Huron; thence along the middle of said water communication into the Lake Huron; thence through the middle of said lake to the water communication between that lake and Lake Superior; thence through Lake Superior northward to the isles Royal and Phelippeaux, to the Long Lake; thence through the middle of said Long Lake, and the water communication between it and the Lake of the Woods, to the said Lake of the Woods; thence through the said lake to the most northwestern point thereof, and from thence on a due west course to the river Mississippi; thence by a line to be drawn along the middle of the said river Mississippi untill it shall intersect the northermost part of the 31st degree of north latitude. South, by a line to be drawn due east from the determination of the line last mentioned, in the latitude of 31 degrees north of the equator, to the middle of the river Apalachicola or Catahouche; thence along the middle thereof to its junction with the Flint River; then strait to the head of St. Mary's River; and thence down along the middle of St. Mary's River to the Atlantic Ocean. East, by a line to be drawn along the middle of the river St. Croix, from its mouth in the bay of Fundy to its source, and from its source directly north to the aforesaid highlands which divide the rivers that fall into the At- 
lantic Ocean. from those which fall into the river st. Laurence: comprehending all islands within twenty leagues of any part of the shores of the Enited States. and lying between lines to be drawn due east from the points where the aforesaid boundaries between Nova Scotia on the one part. and Fast Florida on the other, shall respectively touch the hay of Fundy and the Atlantic Ocean: excepting such islands as now are, or heretofore have been, within the limits of the said province of Nova Scotia.

\section{ArTicle III}

It is agreed that the people of the United States shall continue to enjoy unmolested the right to take fish of crery kind on the Grand Bank, and on all the other banks of Newfoundlaud; also in the Gulph of St. Lawrence, and at all other places in the sea, where the inhabitants of both countries used at any time heretofore to fish; and also that the inhabitants of the United States shall have liberty to take fish of every kind on such part of the coast of Newfoundland as British fishermen shall unc, (but not to dry or cure the same on that island:) and also on the coasts, bays and creeks of atl other of his Britannic Majesty"s dominions in America; and that the American fishermen shall have liberty to dry and cure fish in any of the unsettled bays, harbours and creeks of Nova Scotia, Magdalen Islands, and Labrador, so long as the same shall remain unsettled; but as soon as the same or either of them shall be settled, it shall not be lawful for the said fishermen to dry or cure fish at such settlement, without a previous agreement for that purpose with the inhabitants, proprictors or possessors of the ground.

\section{Articie IV}

It is agreed that creditors on either side shall meet with no lawful imperiment to the recovery of the full 
value in sterling moncy of all bona fide debts heretofore contracted.

\section{Article V}

It is agreed that the Congress shall earnestly recommend it to the legislatures of the respective States to provide for the restitution of all estates, rights and properties which have been confiscated, belonging to real British subjects, and also of the estates, rights and properties of persons resident in districts in the possession of His Majesty's arms, and who have not borne arms against the said United States: And that persons of any other description shall have free liberty to go to any part or parts of any of the thirteen United States, and therein to remain twelve months unmolested in their endeavours to obtain the restitution of such of their estates, rights and properties as may have been confiscated: And that Congress shall also earnestly recommend to the several States a reconsideration and revision of all acts or laws regarding the premises, so as to render the said laws or acts perfeetly consistent, not only with justice and equity, but with the spirit of conciliation which, on the return of the blessings of peace, should universally prevail: And that Congress shall also earnestly recommend to the several States that the estates, rights and properties of such lastmentioned persons shall be restored to them, they refunding to any persons who may be now in possession the bona fide price (where any has been given) which such persons may have paid on purchasing any of the said lands, rights and properties since the confiseation. And it is agreed that all persons who have any interest in confiscated lands, either by debts, marriage settlements or otherwise, shall meet with no"lawful impediments in the prosecution of their just rights. 


\section{Articie: VI}

That there shall be no future confiscations made, nor any prosecutions commenced against any persons for or by reason of the part which he or they may have taken in the present war, and that no person shall, on that aceount, suffer any future loss or damage, either in his person, liberty or property; and that those who maty be in confinement on such charges, at the time of the ratification of the treaty in Anerica, shall be immediately set at liberty, and the prosecutions so commeneed be discontinued.

\section{Article VII}

There shall be a firm and perpetual peace between llis Britannic Majesty and the said States, and between the subjects of the one and the eitizens of the other, wherefore all hostilities, both by sea and land, wall then immediately cease: All prisoners, on both sides, shall be set at liberty; and His Britamnic Majesty shall, with all convenient speed, and without causing any destruction, or carrying away any negroes or other property of the American inhabitants, withdraw all his armie, garrisons and fleets from the said United States, and from every port, place and harbour within the same, laving in all fortifications the American artillery that may be therein; and shall also orter and cause all arehives, records, deeds and papers belonging to any of the said States or their citizens, which in the course of the war may have fallen into the hands of his officers to whom they belong.

\section{Article ViII}

The navigation of the river Mississippi, from its source to the cean, shall forever remain free and open to the subjects of Great Britain and the citizens of the Cnited States. 


\section{Article IX}

In case it should so happen that any place or territory belonging to Great Britain or to the United States should be conquered by the arms of either from the other, before the arrival of these articles in America, it is agreed that the same shall be restored without difficulty and without requiring any compensation.

Done at Paris the thirtieth day of November, in the year one thousand seven hundred and eighty-two.

(Seal.)

(Seal.)

(Seal.)

(Seal.)

(Seal.)

IVitness :
Richard Oswald.

John Adams.

B. Franklin.

JOHN JAY.

Henry Laurens.

Caleb Wintefoord,

Sec'y to the British Commission.

W. T. Franklin,

Sec'y to the American Commission.

\section{Separate Article}

It is hereby understood and agreed that in case Great Britain, at the conclusion of the present war, shall recover, or be put in possession of West Florida, the line of north boundary between the said province and the United States shall be a line drawn from the mouth of the river Yassous, where it unites with the Mississippi, due east, to the river Apalachicola.

Done at Paris the thirtieth day of November, in the year one thousand seven hundred and eighty-two.

(Seal.)

(Seal.)

(Seal.)

(Seal.)

(Seal.)

Witness :
Richard Oswald.

John Adams.

B. Franklin.

JohN JAY.

Henry Laurens.

Caleb Whitefoord,

Sec'y to the British Commission.

W. T. Franklin,

Sec'y to the American Commission. 


\section{INDEX}

Adame, fohn: Suggests French intervention, j3-3 in.; oppuned tis a military comnection with France, il.; prophessies Americall greatness, 21s; appointed enroy to negotiate peace, (0)t. 4,1769$), 261$; wishes to commmonicate dis powers to treat to the Englisll gorernment, 273-5; defend the "to to 1 " act, 2isti: condeavors to demonstrate Frances indebtedness to the Enited states, ib.; thinks France should aid Ansericia more positively, 2zti-7; is sumbled by lergemes and goes to Holland, Bis; Congress asked to curb, 29.5, 2999; superseded loy a commission, 301; participation of, in the peace negotiations, $340,34.5$ -6 ; signs a cleclaration ( $J$ an. 3), 1783) explaining the Provisional Articles, 3ji.

Almodovar: Spanish ambassalor at London, 1S?.

Aranda, Count d': Spanish amhasiador at l'aris and bitter enemy of Englancl, s?; ellthusiastic for an American alliance, 97, 107-8, 17!)-s0 tn.; not a real ambasiador, 10s; recognizes the cxtension of the Inited States lo the Mississippi, $2+1$ fn.; action of, in facilitating peace, 3.j6-i.

Aruenson, Marquis a: Diplomatic policy of, $: 26-\tau$.

Alutrial Value of atliance with, to France, 39, 51, 59.

Balance of lower, Doctrine of: Connected with the balance of trade idea, 15-6, 33-1; logice of comnected with Fronch policy in the Revolution, 17Q.); stated by Verenumes as all argument for lenels intervention in Aneriea, sti-9, $101,13 \pi \mathrm{ff}$; to be alphlied to North America, 21-2, 186, 184.

Bancroft: In iluent of the American commissioners, 1 is and tin.

Batucrott the Historian: Hxplanation of lirench intervention in the Revolution, 2.

Bavarian succession, War of: Cause and settlenent of, 169. 70.

Beaumarchais: Alarmist report on situation in England (17i5), 6is; proselytes the king in behalt of secret aid, 7.-3; his La Paidr ou la Guerre, ${ }^{9} 9$; activities as Hortalez et cie. il.; alarmism after Silratoga, 121 tn., 129-30; memoir of, urering inmediate American recognition (Jan., 17\%8), 155 footnote; anthor of the original form of the Observations sur lo bémoire. ete., 145 and appentix IV; charges Arthur loe with treachery to France, liti fn.; controvery over daims of, 307-3; wity comment of, on spains entry into the war. Qlif fil. 
Belligerency: A status unknown to the Law of Nations in 1776,81 and fin.

Berkeley, Bishop: Predicts greatiness of America, $217 \mathrm{fn}$.

Bernis, Cardinal: Minister of Foreign Affairs $(1756), 32$.

Bonvouloir: Mission of, to Anerica (1775), 73-1; reports favorably on American prospects (Mar., 1776), ib.

Boston: Siege of, jmpresses French opinion, 68 .

Broglie, Count de: His Conjectures raisonnces, $46 \mathrm{ff}$; plan for invasion of England preserved at request of Vergennes, $61-\approx$; plans to become tenporary "Statholier" of the United States, 90-2; memoir on England's enfeeblement (Jan., 1778), 15t-5 fin.

Burgoyne: British general captures Ticonderoga, 117 ; surrenders at Saratoga, 120 .

Burke: Predicts French intervention in America, 52 fn.; assesses the cost to France of her intervention in America, $375-6$.

Canada: Lost to France by the Treaty of Paris (1763), 37 ; significance of English retention of, in preference to Guadaloupe and Martinique, 19-20; not a French objective in the Revolution, 9-11, 70, 74, 200-1 and fn.; French withdrawal from, assists French intervention, 51, 65, 74; wish of France and Spain to leave, in the hands of England, 12 fn., 111, 176, $201-4$ and fns.; V'ergennes' jdea of inaking a free state of, under Freuch protection, $201-2$ and fn.; Washington opposes a Frencll expedition into, 204 . Carleton, Sir Guy: Authorized to negotiate peace in America, 330 fn.

Carmichael: Memoir of, to Vergennes cited, 118 and fn. Cartography: Evidence of, on the Western Land question, $223 \mathrm{fn}$.

Castejon, Marquis de: Nember of the Spanish royal council, and opposed to American recognition, 109.

Castries: Becomes secretary of state for the Marine, 285 opposes peace (178\%), $35 \% \mathrm{fn}$.

Catherine II: Assists in partition of Poland, 45; forms the First League of Neutrals (1780), 172; joins with Joseph II in offering to mediate hetween Great Britain and her foes (1781), 286 .

Charles III, of Spain: I loyal Bourbon, 34: concern at French-American alliance, 161- ; deep resentment at independent course of France, 176-8; character of, sketched hy Florida Blanca, 176-7 fn.; pleased with the idea of mediating between France and England, 184; urges upon Louis the acceptance of a qualified recognition by England of American independence, 185-6; will not recognize American independence before England, 195; disappointment of, at not obtaining Gibraltar, 356.

Chatelet: Correspondence with Choiseul regarding $\Lambda$ merican affairs, 2 ; joins Choiseul in opposing Vergennes' policy, 287.

Chatluam: Attitude toward France and French view of, 3. 35 fn.; lament on Saratoga, 18-9; rumors of prospective return to power, 64-5; in 
exlipse, bit; no likelihoud of his beiner ralled to power atter saratera, 124 til.; rullower respectime, 130, 1.55; opposed to reogernizing Americall independenee after Saratorat. 1:33 fil.; aluo, after the ammonncement of the FrenchAmerican troaty, Jis tis.

(hammont: I secret arent of the French Foreign Office, $126,129$.

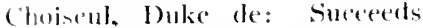
livruis (1754), 333; his M(2rcantilism, 33-t.; obtains the seroud Family Compart, 3.5i: celes Ionisiana to syain, 36 ; Nimoire of $(176.5)$, 3910; considers intervening in bingland's dispute with her (iolonies $(1766-8), 40 \mathrm{ff}$; semclis $\mathrm{k}$ illh to Amerita, 43 ; lisliked ly l,mis XV1, 54; altalks oit, on Verenemes forejern policy. is, 2ki.

Clark, George liogers: Expedition of, arainst British posts in the Nurthwent, 269.

(omminsimers, 'Tlue American:

Agree to transcend their original instructions, $96-7$; would like to involve lirance witl Engrand, 114; endeavor to force the French gavernment's hand, 11s; abandon these tactics atter 'liconderoga, 118-9 and fin.; prefer a coalition with France, 125 tu.; ant citable in support of Vergennes" alarmism after Saratogra, 143-4; negotiations with the Foreigrn Othce, ch. VII; propose a treaty of anity and commerse, 149 ; state their terms. 152-4; fail in their effort to procure inmediately effective gnaranties from France, il.; presentecl at rourt, 16i. See "I)eane," "I.te"," and "lirantliu." ('ompress, 'Tlue Comlimental: semels an agent to Frances, st; atuthorimes a trealy of anity and commeree with France, 9ti; enlareres its instructions to the Anerican enmmissioners, 97 ; effect of British golel on, fuared by Vererenues, 16i3-1; declares against the idea of a separate peace, 20s); cleluates in, ot the Hextern Iand gurstion, 230 fil., 231-2 tn.; parties in, 21.7-s ancl the; relations of, with the Irench enveys, chs. XJ-Xll1; developes agureshive views respecting Anerifitl clains in the livest and fo the Newfomndand fivberies $(1789), \quad 2$ st ff.; actopts instructions of . 1us. 11, 1779 , 2(io); instructions of, to day, respecting the mavigation of the Minsisiple, see "Iay." see turther "Instructioms of flume lis, 17ite" and "Provisional Articles."

"Corsairs": Jhe question of, 99-101.

Courier de leburope: Sensationalism ot, 132 and th.

Deane, Silas: lirst American agent to lrance, arrives in Paris, it: approves 13 roglie's scleme" to become "Statholder" of the United sitates, y); presents Vergennes a plan ot alliance between France, sipain, and the Inited States (Mar. 175\%), 97; negotiations ot, with the English spy, Wentwerth, 127; famous comtroversy ot, with Arthur lece, 207-9; holets landis west of the Mountains to) he at compress' disposal, 219 ; endeavors to rajise money in France on the Hesteril lands as security, $235-9$ and fn. 
Deslandes: Urges importance of naval power to France, 29 30.

Diplomatic Revolution, The: notive for, 23 ; consummation of, 31-?.

Dunkirk: Treaty provisions regarding, 38; stipulation of Convention of Aranjuez with reference to, 193-4; articles concerning, su p press ed (1783), 361.

Durand: Correspondence of, as ambassador at St. James" with Choiseul regarding American affairs, 41.

England: Begins Seven Years' War without warning, 3, 73; offers France and Spain a guaranty of their American possessions (1776-7) 6-7, 1156 ; re-assesses colonial empire in consequence of Seven Years' War, 19-20; colonies, conmerce, and marine the basis of the power of, 18-21, $99,31,41,44,48,50,87,154$ 5 ; hereditary rival of France and enfeeblement of, sought by France, $18 \mathrm{ff}$., 40, 47-50, $69-70,86,89,101,137,139-$ 40 ; overbearing naval policy of $47,51,73,102-3$; plays a waiting game with Spain (1778), 181-2; rejects proffer of Spanish mediation (Mar., $1779), 214-5$; supposed to be enfeebled by the loss of America, 362-4; subordination of, to France resented, 365-6; causes of swift recuperation of, 367-8; recovery by, of American trade, 369-71 and fn.; rapid restoration of fleet of, 371 ; regains the predominance in Holland, 374-5.

Estaing, Count d': Sent with a fleet to North America, 169; address of, to French-Canadians (Oct., 1778), $200 \mathrm{fn}$.
Fanily Compact (1761): Formation and provisions of, 356 ; maintenance of, urged by Choiseul, 40; called by Vergennes "the corner-stone" of French policy, 59 ; loyalty to, pledged by Florida Blanca, 106 ; put in jeopardy by Vergennes' American policy, 135; appeal to, by France feared by Florida Blanca (1778), 175; supplemented by the Convention of A ranjuez, ch. VIH.

Favier: Associated with Broglie in the preparation of the Conjectures raisonnees, 46 ; influence of his work, 48-9.

Fitzherbert: British peace negotiator, $332 \mathrm{fn}$.

Fleury, Cardinal: His système de Conservation and its great success, 23-5; defect of the Système, 28.

Florida Blanca, Don José Moniño Count de: Succeeds Grimaldi as prime-minister of Spain (177\%), 105; characteristics of policy of, toward America, ch. $\mathbf{V}$, passim; his idea of intervention, 112 ff.; opposes a pledge of financial aid to the Americans, 119 ; favors financial aid after Saratoga, but opposes an alliance with the colonies, 157; extreme anger at intelligence of French-American negotiations, 158-60; calculates on leisurely negotiations between France and Spain, 160-1; declines French offer of naval protection for Mexican treasure fleet, 164 ; fears an appeal by France to the Family Compact, 175 ; compared with Aranda, 175 fn.; crystallization of views of, respecting the American peril, 176-78; 


\section{INDEX}

angly correspondenee with Irauda, lig-so fn.; cetlorts of, to make siain metliator rebuffecl by Enerland, 18il; better sucecesis ot. 1sz: wishes to see Inerrients independence neutralized, 181-5; discloses inis intention to make sijanish mbiectives the sine yeri nom

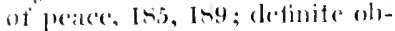
jectives sought hy, for spalin, 190; shapes the Consention of Irimjue:, 191-2; offers lingland Sipanish mediation on the hasis of the status quo in Inerical, zlis-s; recognizes the extension of the Enited sitiles to the Missi-siplei, 240, 2.2; urges the status qua for the I nited states (1780), 271-2; eceentric conduct of, with fay, 319 ff.; admits that spain will not reougnize Inerican independence before England, 3:1-2; lack of selt'possession ot, ib. fin.; emphasizes Spain's interest in her monopoly of commerce in the ciulf of Mexico, 322; solicits terms of a treaty from Jay, 32J-5; angor of, with Arandal jn conseojuenee of Spains falure to obtain Gibraltar by the peace, 356.

Floridas, The': Holker's instructions with reference to (Nov. 25, 1777), 12 fll.; exchanged by Spain for 11avana. 36 ; recovery of', somglat hy Spain, 112, 161, I90-1, 19\%-s. See aluo Appentix 1 .

Forth: British emissary to France (177\%), presenti informally Fnglish demands with reference to Mmeriean privatecers. 115; offers France a guaranty of her Went lndian posensions, ib.; represutations of, go mnsul- jorted, 116-7; offers France al separate peace, 3331 fil.

Fox, Charles: (Quarrel of, with silellimrue over the control of fhe peace merotiations, $331-2$ fin.

France: Motives for entering the lievolution, chis. I and 11, especially ple. 19-53, ch. VI, and appendices Il and Ill; diplomatic object of, in the lith century, $2: 3$ ff., 50 ; guarantor of the 'Jreaty af ll'estphalia, 23, 59, 1(i9-7t); neylects ber mavy, 2s-30; lostes by the Seven fears War, 37s; bumiliaterl by the 'Ireaty of paris, 38; alsi, hy the partition of I'oland, t.j-6; intervention of, in the Revolution foretold, ah. II, note 52; weak navy of $(17 \%(i)$, si fin.; hazardous position ot, early in 1777 , 99; apology at, to Furope for entering the Revolution, 141-s fin.; breaks with England, 168-9; ehampion of nentral rights, 170 2 ; attitude of. on the Whestern Iand question, 2:32 ff.; benefits received by, from the Treaty of Peace, ch. XII pestige of, restored on the Continent, 3til-2: poxition of, aromses Eurlish jealomsy, 365fi failure ot, to secure inericiun trade. 369-7l and fil.; influence ot, threatened by an Austro-kussian rallmochement, 372; temporary trimuph of, in Ilolland, 37t; terrible cout to, of lier intervention in Anerica, 3\%j-6; see also "Spatin" and "Vergrellnts."

Frantin: Foresees Ireneh intervention in the BritishAncrican dispute, 11 fn. 33, 5. fu.; arrives in lerance 
(Dec., 1776), 93; immense reputation of, and its effect on the American cause, 93-4; first audience with Vergennes and demands of, 95 ; joins with Deane and Lee in transcending the Congressional instructions, $96-7$; proposes a plan of alliance to Aranda, 97; intervenes in behalf of American privateers, 100; prepares memoir to the French government with Deane and Abbé Niccoli, 118 fn.; acquiesces in the idea of a truce, 186; holds lands west of the Mountains to be at Congress' disposal, 219 and $f n$.; personal interests of, in an English grant west of the Mountains, 926,302 fn.; treats the Mississippi as the western boundary of the United States (Dec., 1775), ot1 fn.; appointed peace negotiator, 301 ; views of, on method of negotiating peace, $329 \mathrm{fn}$; articles proposed by, to Oswald as "necessary," 330 ; confidence of, in good faith of Vergennes, 333 ; joins with Jay and Adams in negotiating without regarding the Instructions of June 15 , 1781,340 ; returns a soothing answer to Vergennes' reproaches, 341 fn.; signs a declaration (Jan. 20, 1783) explanatory of the Provisional Articles, 357-8.

Frederick II: Makes treaty of Westminster with England (1756), 31; participates in partition of Poland, 45.

Gardoqui, Don Diego: Interest of, in American trade, 320 ; negotiations of, with Jay concerning the naviga- tion of the Mississippi, $i b$. and fn.

Garnier: Chargé d'affaires at London, 64; reports of, on the English situation, 61-6; communicates news of the Declaration of Independence, $\mathrm{S4}$; sends news of the American defeat at Long Island, 85.

George III : Control of Parliament, 4; calls the Americans "rebels" (Aug., 1775); dislike of, for Chatham, 64-5, 124 fn.; obstinacy in matter of American independence, 121-2; slow to recognize that France intends war, $163 \mathrm{fn}$.

Gérard (Conrad Gérard de Rayneval): Secretary to Vergennes, 69; Réflexions of (Nov., 1775), 69-7?; denies that the Americans will become a conquering nation, 110 ; interview of, with the three American Commissioners (Dec. 17, 1777), 150-1; communicates to the commissioners the king's decision to make an alliance with the United States (Jan. 8, 1778), 152-3; sent as first French envoy to America, 169 ; instructed to prepare Congress for a truce and indirect recognition, 187; fails to obtain a farorable declaration from Congress on this subject, 195 ; fails to obtain concessions from Congress for Spain respecting the Floridas, 197-8; participation of, in DeaneLee controversy, 208; obtains declaration from Congress against a separate peace; (Jan., 1779), 209 ; negotiations of, with Congress respecting the Western Land and Fisheries questions, ch. 
Sl: charaterization ot, 26 in.: leaves Intericis in broken health, zol-2: inthurnes ot, sech in l.il I.uzeruecs instructions, 26j- - .

(ibhen the Ilistorian: Author of the Mimoire jasticatif, etc., 114 .

Gibraltar: Vergennes willingne.is to exhange lenen posingsions to secure, for spain (17-2), 6; remery of, desired by Syain, 1\%, 190, $31 \%$; pledire of Consention of Araujuez, with reference to, 193-1; strugrele for (1781-2), 20\%, 293, 313, 3.5: question of, delays peatce, 347 tn., 348 , $3.53,3.51 \mathrm{i}-\mathrm{t}$ and fin.

Girand: I secret agent of the French Foreign Office, 139.

Grasse, Combt de: Commander of French theet in Inerican waters, 293; correspondence ot, with Rochanbeat, 310-9; credit lue, for Yorktown, 313.

Grenville, Thomas: British peace coroy, $331-2$ fu.; mystitying assertions of, 333 and fin.

Grimaldi, Marquis de: l'rime minister of Spain, 86,98 ; is succereled by Florida lilanca, 10.5; cautions Aranda against the dangers of the Innerican example, 108; meets $I$,ee at the Sipanish frontier and turns him lack, $i b$.

Guines, Comut de: Ambassildor to England, sends bonrouloir to America, 73-1: favors an understancling with Eingland and is superseded by Noisilles, 78.

Hartford Conference: l'ro(exdings ot', $291-2$.

IHartley: An English friend of Franklin, 186, 330 fn.
Holker: lirst emissary sent lo America atter Siratoga and first French (omsul at l'hiladelphia, l:0 anel fin.

Holland: Rolations of, to France under 'lreaty ot Vervins, IRt, Isti-7; the Republicall party of, and l'rance, 8.3: breaks with lingland (1781), 25.5; enters into close alliance with France (178.5), 371; lrench influener in, overthrown by England, 375.

IJowes, Ihe: 13ritish commanlers in America, and rumored to be in negotiation with the Anericans, 129-30 and fil.; victory of lord ltowe hefore Gibraltar, 35\%.

IIutton: An English friend ot Franklin, 1:6.

Independence: seope of the Freneh guaranty of, 176, $18: 3$ fin., 19:3. See also "lreaty of Alliance," "Truce," "status Quo."

Instrustions of June 15, 1781: Terms of, 300-1; Congressional debates on, $301 \mathrm{ff}$. passim: explanation of Congress' action in roting, it).; instructions supplementing, 31.5-7; (riticized by Jay, 324; broken by Jay and his associates, 3 3is $\mathrm{fi}$.

Jamaica: Vacillating attitude of Spain towarel proposition to comquer, 17s, 190, 237.

Jay, John: P'resident of Cungress, 219-50; confers with Gerard on the Western Iand and fisheries questions, 2502, 259; appointed ellows to Madrid, 26l: instructions at Congress to, respecting the navigation of the Missiscippi, 261, 270 fin., 280 and t'r., 33:3; appointed peace negotiator, 301; mission ot, to Spain, ch. 
XlV; submits scheme of treaty with Spain, 325; requested by Franklin to come to Pitris, 326; fruitless atlompts at megotiation with Arancla, il.; ceffect ujon, of his spanish experionces, 3278 ; part of, in the negotiations of 1782 , ch. $\mathrm{XV}$; is opposed to Oswald's first commission, $331-3$; suspleions of, and their validity, 333-9, 3.16-9) and notes; sends Vaughan to England, 339; insists on America's fidelity to Irince, $342 \mathrm{fn}$; willing to sce circat Britain reconquer West lylorida, ib.; beneficial results of conduct of, 350-5.

Jeflerson, 'lhomas: Governor of Virginia, appointed peace negotiator, 301-2 and fin.

Jenifer: Manher of Congress irom Maryland, a lader of the "landless" state party, 280 fin., 304.

Kalh, John (later Baron de): Sent to Americis liy Choisen] (1767), 42-3; report of, $113-$ favorable to French intervention, ib.; acts as agent of Broglie, 90.

La Faycte, Marquis de: Comes to America $(1777), 90 ;$ plans joint French-American campaign in Canada, 203; visits France and secures the despatch to America of forees under Rochambeas and 'Ternay, 287-8.

La limerne, Chevalier de: Seeond plenipotentiary to the Inited States, characterization of, 263-4 and fn.; Vergennes' first instructions to, 5.56-6; negotiations of, with Congress respecting spain's interests, 267 ff.; Vergennes' later instructions to, fouch- ingr this matter, 278-9, 281; nerotiations of, with ('ngress leading to the lustructions of Jume 15, 1781, 297 ff.; assents to an American invasion of Canada (178t) 305; details American expecfations from the treaty of peace, $308-9$ and fu.

laurens, Ilenry: Aplointed peace negotiator, $30 \mathrm{I}$; is (al)tured by the British and lodged in the 'Tower of $\mathrm{L}$ ، $011-$ ton, 302 fin.

Lanrens, Col. John: Is sent to France by Congress to obtain a loan (Feb., 1781), 292 and fin.

Lee, Arthur: In london (1775), 66 ; goes to Spain and is turned back (Mar., 1777), 98; accused of communicating the French-American lreaty to the British govermment, 166-7 fn.; controversy with Deane, $007-8$; is preventect hy La lazerne from heeoming secretary of l*oreign $\mathrm{Af}$ fairs, 265 ; criticism of, on the Instructions of June 15,1781 , $30.5 \mathrm{fn}$.

Lee, Richard Ilenry: Attitude of, on question of a separate peace, 208 and $\mathrm{fn}$.

livingston, kohert R.: Vilection of, to secretaryship of Foreign Affairs is promoted ly La Inzerne, 265 ; letter of, to Franklin (Jan., 1782) in support of American claims in the West, $316 \mathrm{fn}$. See "Marbois."

Long Island, Battle of: Bad effect of, on American prosprects in Franee, 8.5-8.

louis XV: His secret du Roi, 4.5; unpopular at death on account of Franec's humiliations aloroad, $51 \mathrm{fn}$. 
Jouis XV1: Pledges reforms. 7 . (6) and in.; dislikes idea of alding rebels, $x$ fn. and appendix N; chooses cabinet, 5t; ratites the policy of secret aid, 79: cxlends tinimeial aid to the colonies, 9;-6, 120; agrees to war with Englemel and an allianer with the conited states if spain is favorable, 10:3-4; decides to make new grift to Americal, 120): convinced of "the moral cretainty of peril," 129 and fn., 14:-3; point of view of, to be distinguished from that of the loreign (Iffice, 1.45; anthorizes the declaration of the Treaty of Amity and commerce (Mar. 7, 1738). libi-7; sends letters to Conuress. 16s-9; on the point of itopling the war for finan(rial reasolls $(1780)$, 284-5; goes to the guillotine, 355.

Louisiana: Not a French objective in the Revolution, 911: transferred by France to spain (1762), 36." See "Mississippi and Western Land (Silestion."

Madison, James: Argument of (cot., 1780), against Sirain's (laim of a rigbt to conquer British possessions along the Minsissippi, $270-1$ fn.; eriticizes the conduct of the American peace negotiators, $341-5$.

"Manifest Destiny": Origins of the idea, $217-19 \mathrm{fn}$.

Marbois: Seeretary to la l.nzerne, urges Spain's rlaims upon Congress, 280-1; letter of, opposing the American ('laims to the fisheries. 337-8 and fn.

Maria Theresa: Assists in the partition of Poland (1752), 4j: desires peace (17in), 170.

Ilarvland: Opposes the elaims of the "landed" states, $2 \geq 0$ til., 232.

Maurepas, Comnt de: Urges restoration of French Marine $(1730-40)$, 28-9; urges a helligerent policy toward England, 7 - -9 and fn.

Mercantile sytem: leading ideas of, $15-7$ and for., $28-9$, 33-4; connection with lirench intervention, 1s-9, 4l-?, 1t.

Miralles, Juan de: Spanish agent, arrives in Anerioa, $243-4$; views of, on the conflicting interests of spain and the United States, 2 i.1-5 and fn.; determines views of Gerard, 245 ff.; proposes purchase of American chans in the West, 251-2; spreals false reports respecting Spain's attitude, 255; admits lack of powers or instruce tions from Madrid, 269 ; dies, 280.

Mississippi and Western Land Question, 'The: See rhe X$\mathrm{XII}$; also chs. XIV-XV passim.

Monroc boctrine. The: Some antecerlents of, $201 \mathrm{fn}, 369 \mathrm{in}$.

Montmorin, Count de: liriend of Iouis and Vergennes, becomes ambassador at Madrid, 156; urged hy Vergennes to arouse the Spanish government to an appreeiation of the opportunity presented by the Revolution, 156-7; ellcompters Florida Blanca's wrath at the action of Erance in negotiating with the Amerieans, 158-60; says that Spain wants "shining ohiects." 161: is sceptical of value of Spanish aid, 180; igns the Convention of Aran- 
juez (Apr. 12, 1779), 192; warns Vergennes of Spain's hostility toward America, 216.

Morris, Gouverneur: Views of, on the Western Land question, 248-9.

Nentrals, Rights of: French goverument champions, against English sea-power, 21, 80-1 and fn., 170-9. See "Catherine II."

Newfoundland Fisheries, The: An enlargement of rights in connection with, offered France by England (1778), 7 fin.; a share in, desired by Spain, 161, 178; French pledge with reference to, to Spail, 191, 197-9 and fn.; Congressional views respecting $A$ merican rights in, 257 ff.; final instructions of Congress concerning, 314-6. See appendix $\mathrm{V}$.

Noailles, Duke de: Opposes France's entrance into the War of the Austrian Succession, 99 ; succeeds the Count de Guines as ambassador to England (1776), 78; reliability of reports of, from London, 131 ; points of disagreement of, with Vergennes, 1312; communicates the Treaty of Amity and Conmerce to the British government, 168; leaves England, $i b$, and $f n$.

North, Iord: Sentiments attributed to, loy Vergennes, 131,133 ; introduces plan of conciliation into Parliament, 165 and fn.; fall of, from power, $331 \mathrm{fn}$.

Ossun, Marquis d': Ambassador at Madrid, 103; supplanted by the Count de Montmorin, 156.

Oswald, Richard: British peace negotiator, 330 ff. passim.
Parliament: Debates in, after Saratoga, 133 fn.

Peace Negotiations of 1782: Early stages of, 329-32 fns. See "Jay."

Phillips, Dr. P. C.: Views of, respecting the results of Jay's conduct of the peace negotiations considered, 350 fi.

Poland, First Partition of: in relation to French diplomacy, 45 ; denounced by Vergennes, 57.

Pontleroy: Early French agent to America, 40-1.

Price, Dr. Richard: Predicts American greatness, $218 \mathrm{fn}$.

Proclamation of 1763, The: considered in connection with the Western Iand question, Q21-7 and notes.

Provisional Articles, The: Provisions of, see appendix $\mathrm{V}$; the signing of, $339-40$; questions respecting the jnterpretation of, 340 fn.; real import of, 342 ; reception of, hy Congress, 344-5, 354-5; estimate of, by the French Foreign Office, 355 and $f n$.

Quebec Act, 'The: Bearing of, on the Western Land question, $226-7$ and $\mathrm{fn}$.

Raynal, Abbé: His Histoire des Indes on the inportance of navil power, 48-9; influence of his work, $i b$.

Rayneval, J. M. Gérard de: Secretary to Vergennes, on the status quo, 296-7 fn.; representations of, to $J$ ay on the Mississippi question, 336 ; mystery surrounding journey of, to England, $i b$.; Jay's suspicions regarding, 339 ; finds Shelburne stiff on the question of Gibraltar, $347 \mathrm{fn}$.; conversations of, with Shel- 
hurme respecting Americall introusts, 318 fi. anel fin.; matrels at the sureess of the Murericans, 355.

linmelen: Successor to Miralles, ב's).

Rijelmumet, I orrt: Arfocites Imerican inclependenec, 133. lionhambeatu, Comnt de: Bringe a military forete to the Unitad sitates $(1780), 276-7,288-9$; (lecp concern of, on ateount of Amarifan tomditions, 2y, $310-1$; credit tuc, for lurktown, $311,313$.

leochforel, Ioord: Sihreme for joint guaranty of fremel, Goanjoh and Eugrish posisessions in Arneriea, $6-7$; friend of Boamuarehais, 65.

Rockingluam, loord: Rumored hostile intentions of, towaral France, (jis; advocates untpalified intepremalence for the Americans, 13:3 fn., liks tin.; surcerefs North, 3.31 fil.; dith, $333 \mathrm{fn}$.

Rudney: British admiral, defoat: Grasse in the: West lndies (Ajr., 1782), 316i-7.

Pinulle: Minister of the Narine, (1749), 31 .

Sinint-Contest: Secretary of state $(1751), 30$.

sit. Ciermain: Secretary of state for Har, and favorable to an ageressive diplematic puliey, 78; semels strubers to Amcrica, 90; is supplantret liy siterur, 2xis.

Sandwirh, Iaral: Nember at the British ministry, not inthor of sentinent at tributed to him, 132; estimates I3ritish naval strength, 134.

Sinto Domingo: Qpuestion of defonse at, $;$ tin., $89-9)$ fin.

Saratoga, Battle of: Bringe about the French-American alliance, 120, 121 and fil., 111 .

Siartines: Sieretary of state for tle Marine, favorable to all ageressive diplonatic [ouliey, 78; is disjulated by ('astrixs, 28.5.

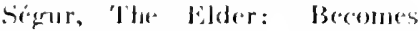
secercotity of state for War (1781), 245.

"Sieato-tose" charters, The" As basis of the elaims of the foited Siates in the: Wiest, 2.) ff.

Sereret Aid, l'oliey of: Sire

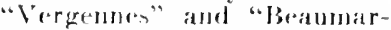
"hati"; kejet a secret covel from tles Americans at first, so); raises diplomatic guestions, so-1; the secret ot, knewre to the British goverse merut, 9:3 and fil.

"Sicoret Article": ()f the "lreaty of Alliance, sre allpenelix I; of the I'rovisional

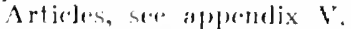

"Sieret du Roi," 'The: Sies "I osuis X V".

Separate Peace: Origin of the idea ot, betweerl Eligland and American, 206; motion comeloatted by Verenentes, it.. disavowel by Comgress, zos and ful.

Seven Years War: Begrum by lingland witlunt warming, 3 ; anspicions opening of, for France, 31; (alamitias of later stages of, $32 \mathrm{ff}$.

Shelburne, Jard: l'art of, in instituting tles peace negotiations of $1782,331-2$ fn.; gerod faith of, doubted by .lay, 3.3.3$\therefore$ atud notes; autborizes ():wald's secomel commission, 3339; romferene.s wt, with Ravneval, 339, $31 \%$ frt., 31850 fu, ; refuses to take Jarliancent into lis anficlesece respereting the l'rovisional Arti- 
Cles, inte th. ellert on, ot llawes victory before (iibraltar, $3, i_{3}-3 ;$ irges a lirenchbi $n$ ir 1 is h repprochement anatist the noethera powers, :ii:-i3 til.

sprain: Dispute of, with lortugal wer interests 11 somtli Inseriear $(177 \cdot t-7)$, 61 , S1-3, 10.t; is alatined at Itic prosperet of Amerionu inclependenter, chs. I' amol V'III Passim: tomporizimg atlitude of, 1\%-9 and fu. : fuestion of the value of aid ot, lo lirance, 1,il, 2ll-g and tu.; secks rôk of mediator lis( ff.; selfsceking policy of, 106, 16il. 17., 180, 19:; tesires a monepoly of trate in the ('arihhe:411, 175, 190, 32:; desires to recoser the liluridas and a share in lhe Newfommdlatud tisheries, see nuter those headings: timal lerms of mediation of, 21t-5; cuters the war (June, 17\%9), 216; grant by, of navigation of the Mississippi to British subjects (1763), 237-8 f11.; (p)poses Anerican extelssion to Hat Mississippi, 23-30; attempls of, to milke concjuests along the Mississippi aromse Anerican opposition, 20s-!) and fin.; sectet neerentiations ot, with Fngland $(1780), 271-$ 3 re-enters the war (178t), sit; interests of, preferred hy france to those of the inited sitates, sos-t; ambitions oft, a bar to peacer, $3: 33-$ 4. 346-7, 353, 355-7; Intericatu gratitucle elatmed for, 345. Sec "lorida Hlamea," "1Raymeval," "Vergennes."

Spics: Numeroms in paris in $1777,98$.

status (o) Tho, Ite: Opposition ut lerenturs lo, for the

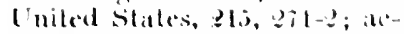
coptance ot, by lerance for the lonited states atmilled ly lergemes to be possible (Iinl), anti-s and notes; rejected ly Verentates tior the Enited Sitales, :31t in.

Slenben, liarou roul Sent to Imerica ly st. Cicrouain, to traile the Anterican atem $(17 \% 7), 90$.

Stormont, lorel: Britisls amhassacher at l'aris (17\%t ti.), 6it; discusse's, the Antericitn situation with Verenctures (tiept., l7zis), ib.: remmolstralus anginst sereret atid, 93:3 aud tin.; remomstrates ingatust the admission of Anterican privateers to lerench harbors, 100: charges Jergenues with negotiating wilh the Ameriatts, 163-5; atroids a catcguriat answer froul the French governutent, ib.; leaves France, fos and fin.

Sullivan, Cincral: "thero of Newport," sells out to the lecmoh envoy, 303.

Sweden: ('oup atutat in, effectal by lecrentes $(17 \% 1)$, j.

lermay: French maval comimanider, sece "Rochambeam."

Ticonelerogis: British capture of, injures Americin prospeots in France, 117.

Treaty of Alliance (Feb) 6 , $17 z \dot{8})$ : l'rincipal teitures of, antlurized hy the royal (2oute(il (Jitn. 7, i 788 ) : final dialt of., simused, 15t: text of, alppondix I; existemes ot, suspected in lengland from an ciarly date, $16: 3$ fo., 165-6 and in.: meaning of the wort "continent" in nrticle. VI at, 19) and fin.; interpretation af articles Xl and Xll of., 


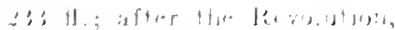

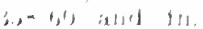

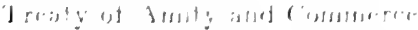

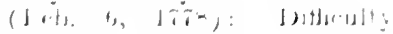

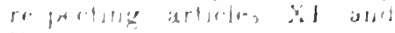
XII of, 1, III, irtiel.

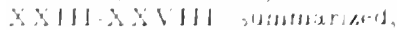

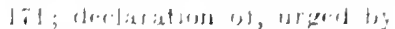

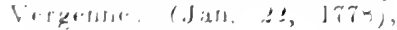

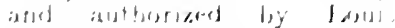

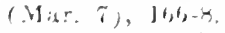

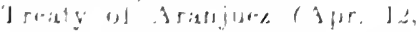

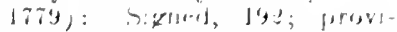

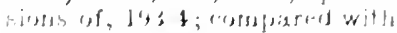

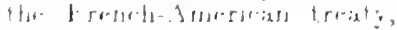
rit. $1 X$.

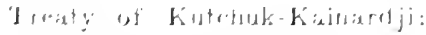

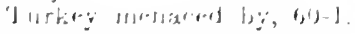

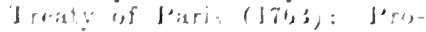

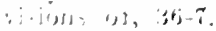

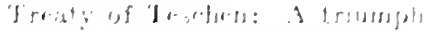

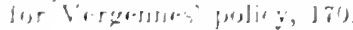

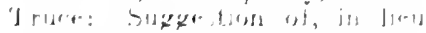

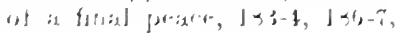
13; $⿻$ ().

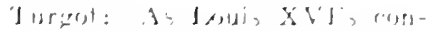

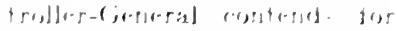

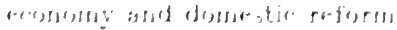

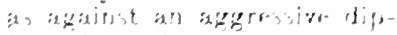

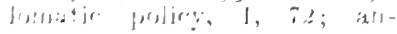

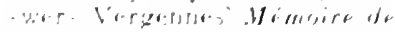

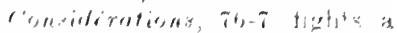

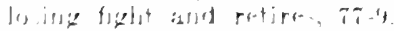

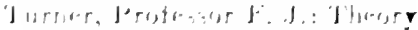

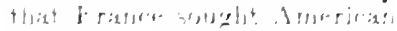
perritar: in the lavereletiest, s-1] aluit lol

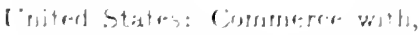

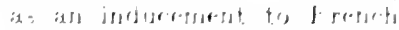

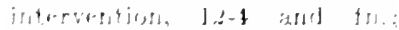

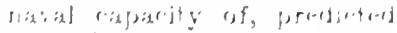

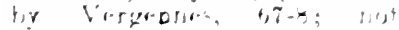

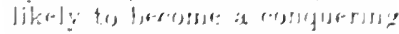

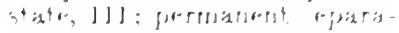

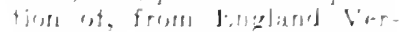

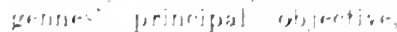

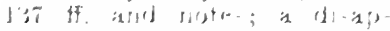

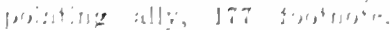

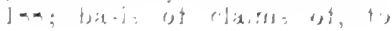

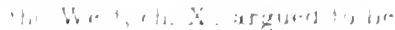
is 4)

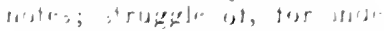

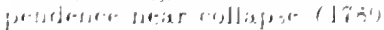

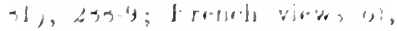

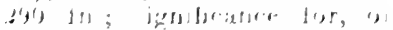

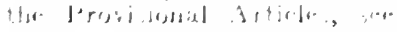

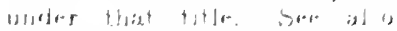

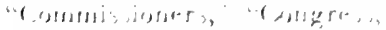

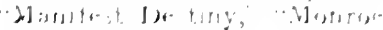
fuenthin.,

Vis J

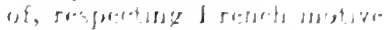

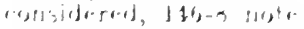

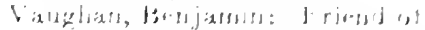

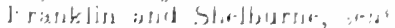

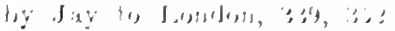

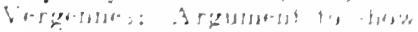

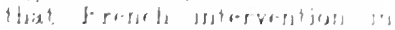

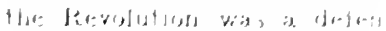

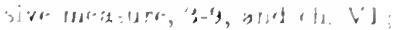

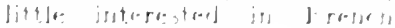

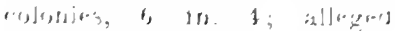

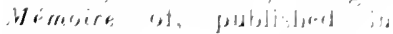

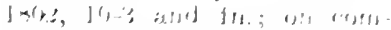

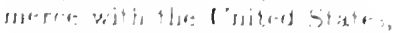

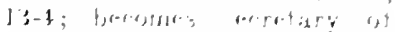

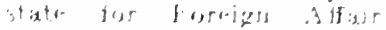

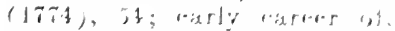

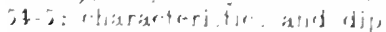

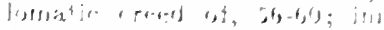

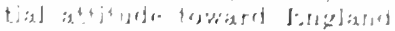

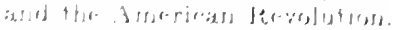

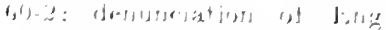

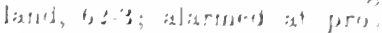

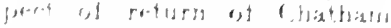

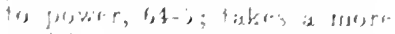

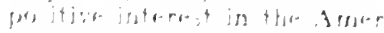

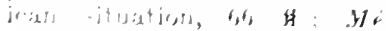

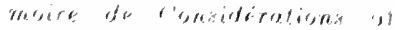

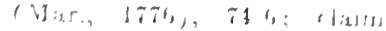

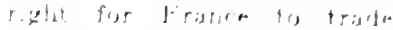

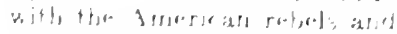

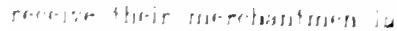

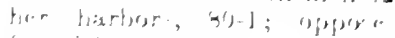

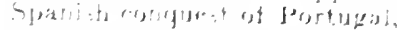

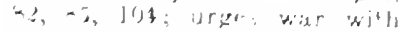

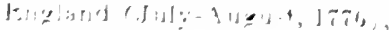

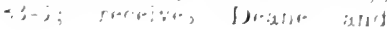


learns of Declaration of Independence, 84 and $\mathrm{fn}$.; draws back after the news of Long Island, 85-6; conrratulates Stormont on British successes, 86 ; pursues a policy of "watchful waiting" (Jan.-July, 1777), 87 ff.; urges the preëminent interest of France and Spain in procuring the separation of England and North America, 869 ; delivers a homily on peace, 88 , opposes a general disarinament and an understanding with England, 89 and fn.; question of attitude of, toward Broglie's Statholderate idea, $91-2$; receives Franklin but evades a formal audience, 95 ; promises financial aid to the Colonies (Jan. 1777), 95-6; precautions in behalf of secrecy, ib. fn.; is sceptical of the substance of the American revolt (Mar., $1777), 97$; is sceptical of rumors of an hostile EnglishAmerican coalition (early 1777), 99; policy of toward American privateers, $99 \mathrm{ff}$.; agrain urges war with England (July, 1777), 101-4; endeavors to allay Spanish apprehensions regarding American independence, 111, 177 fin.; consents to follow Madrid's lead (Aug., 1777), 1134 ; urges that Forth's demand that American privateers be excluded from French ports be rejected, 115-6; anticipates the early outhreak of war with England (Sept., 1777), 116; again retreats after the arrival of the news of 'Ticonderoga, 117; proposes a pledge of financial aid to the
Americans, 119-20; renews in a new form after Saratoga the idea that French possessions in the West Indies are in danger of being attacked by an EnglishAmerican coalition, 121-5; evidence brought forward by, to support this notion, 12634 ; instances of disingenuousness of, in this connection, 132-4; contradictions and inconsistencies of, 135-8; declares enfeeblement of England to be France's principal objective, 139-40 and fns.; urges defensive aspect of his program, 140, 167, fns.; real concern of, after Saratoga, 141 ; reason for alarmism of, $142 \mathrm{ff}$; initial advances to the American commissioners after Saratoga, 149-50; offers a defensive alliance, 151-3; resists American demand for an offensive alliance, 154; urges his policy on the Spanish government, 155-7; finesse of, in delaying transmission to Spain of news of the French-American negotiations, 159; significant interview with Stormont ( $\mathrm{Jan} .22$, 1778), 161; presses for an open breach with England, 161 ff.; distrust of Arthur Lee, 166-7 fn., 187; policy of, in War of Bavarian Succession, 169-70; adopts liberal policy toward neutral rights, 170-2; impatience of, to bring Spain into the war, 173,178 , 180,188 ; willing to support Spanish mediation, 182; careful of American rights, 183 fu.; attitude of, toward idea of a truce instead of a peace for America, 186-7; gives Montmorin carte-blanche in 
negotiating with spain, 1s9: sends Hontmorin a draft of treaty with Spain, 190; aims to safeguard France's honor with respect to American interests, 192-3; instructions of, to (ierard with reference to a truce, 196 ; same, with reterence to the Floridas and Canatia, $197 \mathrm{ff}, 254$; plans a tree state in Canada under French protection, $201-2$; combats the itlea that Ameri(a) may make a separate peace with England, 2065 ; bitterly criticizes Florida Blancas terms of mediation (Apr., 1779), 215 ; recognize, the extension of the Inited staten to the Mississippi, 240 $\because$ and notes; favors American navigation of the Mississippi, $254-5$; adopts the Spanish point of view in his Instructions d Arrive to La Luzerne, $26.5-6$; fears that Spain seeks to impose the status quo on the Cnited States $(1 \tau-i 0), 2 \tau 1-2$ and fll.; altercations of, with John Idaus, 273-s: instructs La Luzerne not to take sides in matter at issue hetween Spain and America, 278-81: review of attitude of, on the Mississippi question, 251-3; intercedes with the king to eontinue the war (Sept., 1780), 284-5; reorganizes the Departments of War and llarine, ib.; favors the offer of mediation by the imperial powers and a vigorolls eampaign, $286-\tau$; disappointed in the American, as allies, 259 : response of. to the demands of the Hartiord Conference, 29?-3; considerations governing, at this timle, 393-4; demands of, upon (a) making, 295-6; admission of, that France may accept the status quo for the United stister, 395-s and notes; broad scope of the program of, in intervening in the Revolution, 307; not directly responsible for the Yorktown (ampaign, 313 ; recognizes the unfeasibility of the status que for Aneriea, 313-1 fr.; views of an to the method to be pursued in peace-making, 329 fin.: refuses to treat with Grenville respecting American interests, 332 fin.; urges the American commissioner: to aceept Oswalds first eommision, 332-3; announces that France will not proceed with England nnles, she is ready to recognize Anerican independence, 334 fn.; is noncommittal as to the conflicting claims of Spain and the Enited States, 336; comment of, on Marbois letter respecting the fisheries, 3.37 fn.: announces that France will not eontinue the war to iecure American demands respecting the fisteries and Western territory. $337-9$ fin., $31 \%-4$ fn.; letter of (Dec. 15. 1; $: 2)$, to Franklin protesting anainst the course takel by the American eommisioner: 340-2; states the two erimtial conditions of peace, 347 fn.; expresses surprise at the favorable terms secured by the Americans, 355 and fn. presses the negotiations in Spain's hehalf, 355-6; delight of, at the conclusion of peare, 3.56-7: opposed by a war pirty at court, $35 \%$ fn.; reriews the suceess of his poliey 
(Mar., 1784), 361-2. desires the gratitude of the American people for France, 368-9 and fn.; negotiates a commercial treaty with England (1786), 371; urges a strong fleet for France, $i b$.; is disinayed by the rapprochement of Austria and Russia, 372; admits that Continental peace is precarious, 373 ; wins his last diplomatic triumph. 374; death of, 376 ; final apology of, for his American venture, 376-7.

Virginia: Claims of, in the West, 221, 222-4 fn.

Washington, General: Opposes French participation in a campaign in Canada, 204; views of, on the Western Land question, 251 fn.; growth of French regard for, 291 and fn.; attends Hartford Conference (Sept., $1780), i b$.

Wentworth, Paul: Activities as British spy, $118 \mathrm{fn} .127$ and $f n ., 130$ fn., 163. in.

West Indies, The French: and the Treaty of Paris, 19-20,
37 ; value of, after $1763,5-6$ and fn., 44, 63, 75-6, 136-7; independence of, proposed by Choiseul's secretary-general of Commerce, 44; asserted to be in danger from a joint English-American attack, 3, 75, 98-9, 121 ff.; English offers to guarantee, 6-7 and fn., 115-16; American offers to guarantee, $21,95,97$; chosen for the scene of French-Spanish naval efforts (1781), 287, 293; Grasse's defeat in, by Rodney, 313, 316; equivalents demanded in, by England in return for Gitraltar, 355-6 fn., 357 fn.; great French-Spanish expedition prepared for (1783), ib.; French gains in, by the Peace of 1783 insignificant, 361.

Witherspoon: Member of Congress from New Jersey, a leader of the "landless" state party, 304.

Wolfe, General James: Prophecy by, of America's destiny, $218 \mathrm{fn}$. 



$$
x_{a_{a_{2}}}
$$





LIPRAFY UF CONGAFESS

||||||||||||||||||||||

00098017239

00008017239 